\title{
Cell biological aspects of muscle cell differentiation
}

Citation for published version (APA):

van der Loop, F. T. L. (1996). Cell biological aspects of muscle cell differentiation. [Doctoral Thesis, Maastricht University]. Datawyse / Universitaire Pers Maastricht. https://doi.org/10.26481/dis.19960229fl

Document status and date:

Published: 01/01/1996

DOI:

10.26481/dis.19960229fl

Document Version:

Publisher's PDF, also known as Version of record

\section{Please check the document version of this publication:}

- A submitted manuscript is the version of the article upon submission and before peer-review. There can be important differences between the submitted version and the official published version of record.

People interested in the research are advised to contact the author for the final version of the publication, or visit the DOI to the publisher's website.

- The final author version and the galley proof are versions of the publication after peer review.

- The final published version features the final layout of the paper including the volume, issue and page numbers.

Link to publication

\footnotetext{
General rights rights.

- You may freely distribute the URL identifying the publication in the public portal. please follow below link for the End User Agreement:

www.umlib.nl/taverne-license

Take down policy

If you believe that this document breaches copyright please contact us at:

repository@maastrichtuniversity.nl

providing details and we will investigate your claim.
}

Copyright and moral rights for the publications made accessible in the public portal are retained by the authors and/or other copyright owners and it is a condition of accessing publications that users recognise and abide by the legal requirements associated with these

- Users may download and print one copy of any publication from the public portal for the purpose of private study or research.

- You may not further distribute the material or use it for any profit-making activity or commercial gain

If the publication is distributed under the terms of Article $25 \mathrm{fa}$ of the Dutch Copyright Act, indicated by the "Taverne" license above, 
Cell biological aspects of muscle cell differentiation 
CIP-GEGEVENS KONINKLIJKE BIBLIOTHEEK, DEN HAAG

Loop. Franciscus Theodorus Lambertus van der

Cell biological aspects of muscle cell differentiation /

Franciscus Theodorus Lambertus van der Loop. - Maastricht:

Universitaire Pers Maastricht, - III.

Thesis Filiksuniversiteit Limburg Maastricht. - With ref. -

With summary in Dutch.

ISBN 90-5278-211-3

Subject headings: muscle cell differentiation / titin / smoothelin.

Cover illustration: Titin cross-striations in primary cultured neonatal rat cardiomyocytes. 
Cell biological aspects of muscle cell differentiation

\author{
Proefschrift
}

ter verkrijging van de graad van doctor

aan de Rijksuniversiteit Limburg te Maastricht, op gezag van de Rector Magnificus, Prof mr. M.J. Cohen, volgens het besluit van het College van Dekanen, in het openbaar te verdedigen op donderdag 29 februari 1996 om 14.00 uur

door

Franciscus Theodorus Lambertus van der Loop

geboren op 8 oktober 1964 te Oss. 
Promotor: Prof. dr. F.C.S. Ramaekers

Beoordelingscommissie:

Prof. dr. G. van der Vusse (voorzitter)

Dr. M. van Bilsen

Prof. dr. M. Borgers

Dr. A.F.M. Moorman (Universiteit van Amsterdam)

Prof, dr. B. Wieringa (Katholieke Universiteit Nijmegen)

The investigations described in this thesis were carried out at the Department of Molecular Cell Biology \& Genetics, Cardiovascular Research Institute Maastricht, University of Limburg, Maastricht, The Netherlands.

The project was supported by the Netherlands Heart Foundation (De Nederlandse Hartstichting).

Publication of this thesis was financially supported financed by:

Bio-Rad Laboratories B.V., Veenendaal, The Netherlands. 


\section{Contents:}

Chapter 1: General introduction: 7

Embryological origin and early development of muscle cells.

* Muscle types.

Skeletal muscle.

* general characteristics

* embryological origin and development

* transcription factors regulating

skeletal muscle differentiation

* the sarcomere

- Cardiac muscle.

* general characteristics

* embryological origin and development

* transcription factors regulating cardiac muscle differentiation

Smooth musclie.

* general characteristics

* embryological origin and development

* Cytoskeletal and structural proteins in muscle cells.

* Outline of the thesis.

Chapter 2: Titin expression as an early indication of theart and skeletal muscle differentiation in vitro. Developmental re-organization in relation to cytoskeletal constituents.

Chapter 3: Integration of titin into the sarcomeres of cultured differentiating human skelletal muscle cells.

Chapter 4: Expression and organization of muscle specific proteins during the early developmental stages of the rabbit heart.

Chapter 5: Rearrangement of intercellular junctions and cytoskeletal proteins during rabbit myocardium development.

Chapter 6: Smoothelin, a novel cytoskeletal protein specific for smooth muscle cells.

Chapter 7: Smoothelin: a marker of differentiated human smooth muscle cells in normal arteries and arteriosclerotic lesions.

Chapter 8: Generall summary.

Chapter 9: Samenvatting.

List of publications. 

General introduction:

Embryological origin and early development of muscle cells.

Muscle types.

On basis of morphologic and functional characteristics three types of muscle tissue can be distinguished in the vertebrate body, i.e. skeletal, cardiac and smooth muscle [43]. They all originate from the mesoderm, and are composed of asymmetric cells or fibers with their long axis arranged in the direction of motion. Skeletal and cardiac muscle are also referred to as striated muscle because of the conspicious transverse striations of the individual cells when examined by light microscopy. The sarcoplasm (cytoplasm) of both types of striated muscle cells contains long cylindrical filamentous bundles called myofibers, which have a diameter of $1-2 \mu \mathrm{m}$ and run in the long axis of the muscle cells. Myofibers consist of sarcomeres. These contractile units of striated muscle cells have a high level of organization of thick myosin filaments and thin actin filaments. Interaction between actin and myosin filaments is also the basis for the contractility of smooth muscle, but the filaments are organized in slightly deviant directions along the longitudinal axis of the cells. Therefore, smooth muscle does not show intracellular striations [62].

\section{Skeletal muscle.}

General characteristics.

Skeletal muscle is the result of cell fusion [62]. Mature skeletal muscle cells have many peripherally located nuclei, and are extensively elongated. They are also referred to as (multinucleated) myotubes, differentiated skeletal muscle cells, or myo-syncythia. Skeletal muscle is controlled by the somatic nervous system and, therefore, often is called voluntary muscle. Skeletal muscle is the most investigated muscle type as far as the molecular processes involved in its 
differentiation are concerned.

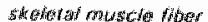

hogary miscile fitwers

snooth muscile
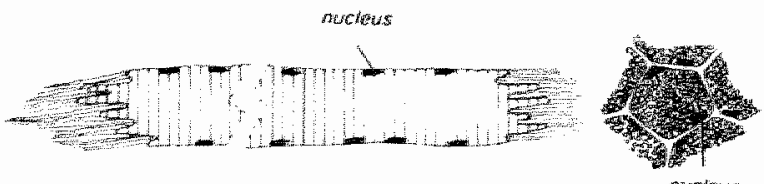

nercieus:
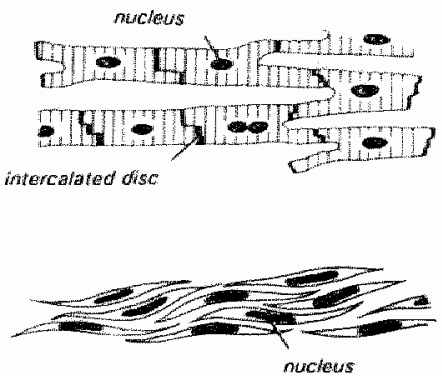
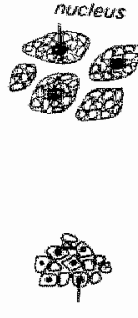

nucreus

Figure 1.1: Schematic representation of the different muscle cell types.

(Adapted from Junqueira, 1989 [62])

Embryological origin and development.

Skeletal muscle is generally considered to originate from pluripotent primitive cells of the dorsal (somitic/paraxial) mesoderm. During embryonic development, mesodermal cells become clustered in somites, separate groups of cells in a fibronectin-rich matrix, originating from the paraxial, unsegmented mesoderm. The first somites appear in the anterior portion of the embryo, and new somites are formed posteriorly at regular intervals, budding from the paraxial mesoderm. The dorso-ventral polarity of the somites is determined by the notochord and the neural tube.

As the somites become coherent entities, their cells obtain an epithelial morphology. The outer cells of the somites form tight junctions, and the somites become covered with a basal lamina consisting of collagen, fibronectin, laminin, and glycosaminoglycans. The ventral cells of the somites undergo mitosis, lose their round epithelial morphology, and show mesenchymal characteristics. The part of the somite that gives rise to these cells is called the sclerotome. These cells ultimately become chondrytes, which are responsible for secreting the special variants of collagens and glycosaminoglycans characteristic of cartilage. The chondrytes are also responsible for the construction of the axial skeleton. Once the cells of the sclerotome have migrated away from the somite, the remaining somitic epithelial cells (the "dermamyotome") form a bilayered, solid tube. The dorsal layer, the dermatome, generates the mesenchymal connective tissue of the skin, the dermis. The inner layer of cells, the myotome, gives rise 
to the striated muscles of both the back and the limbs $[21,45]$.

After receiving appropriate signals, the mesodermal cells in the myotome become myoblasts, the proliferative stem cells of skeletal muscle. Growth arrest and withdrawal from the cell-cycle initiates a series of differentiation steps

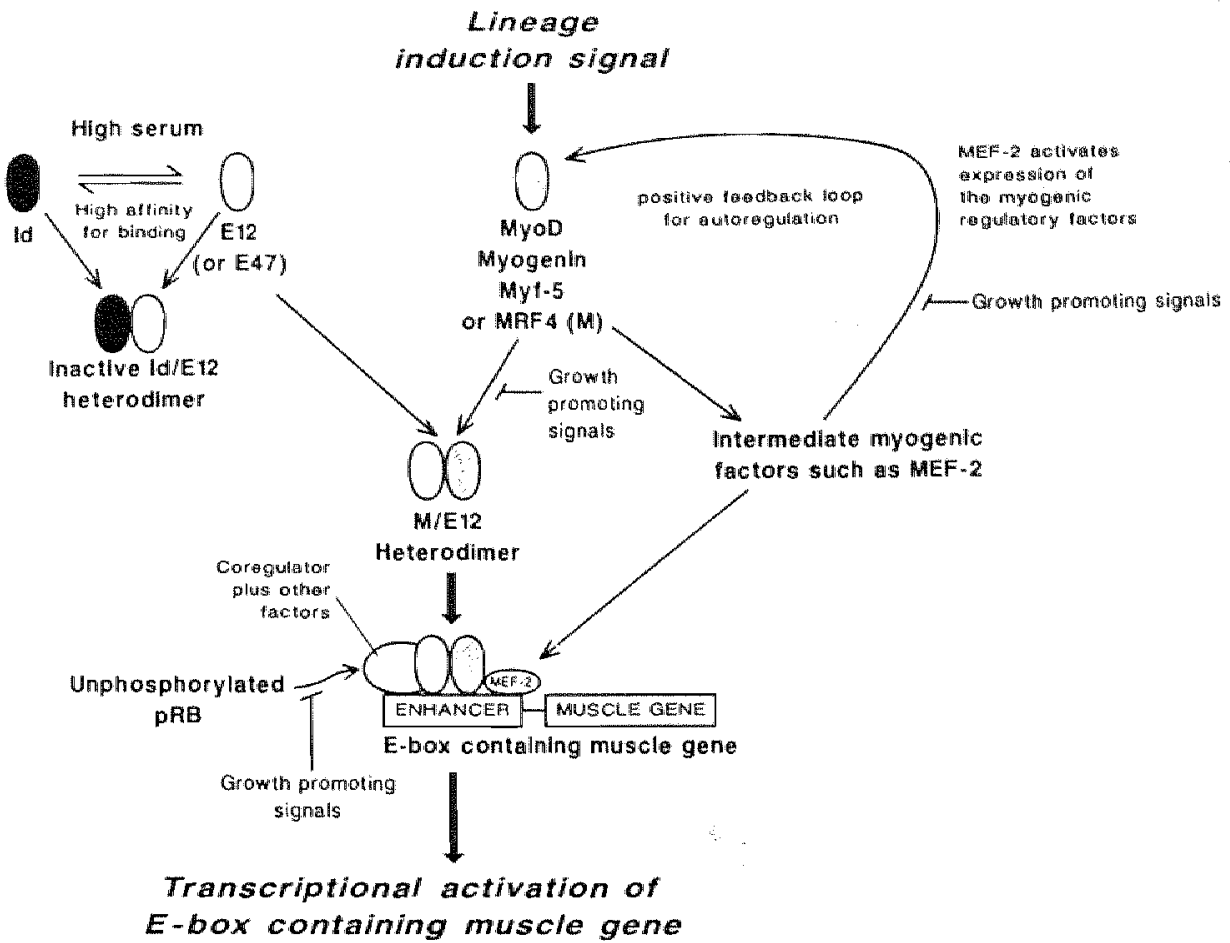

Figure 1.2: Schematic representation of the process of myogenesis during embryonal development, with the expression of transcription factors and the expression of titin and the intermediate fillament proteins keratin, vimentin and desmin indicated at the different stages.

- : no expression, $+1-$ : decreasing expression, $-1+$ : increasing expression. + or ++ : level of expression (Adapted from Dias, 1994 [26]).

which induce the individual myoblasts to fuse and to form multinucleated myotubes (Fig. 1.2). The nuclei of such myo-syncytia migrate to the periphery as 
they develop to become myofibers, the basic units of mature skeletal muscle. The fusion and maturation process requires the coordinate expression of numerous muscle specific genes fo form the muscle contractile apparatus, that consists of contractile units called sarcomeres. Mutual exclusion of growth and differentiation is characteristic for skeletal muscle cells. Cells induced to differentiate, either by transcription factors, by growth factor-induced immediate early gene products, or by depletion of peptide growth factors do no longer proliferate, and, once induced to differentiate, cannot de-differentiate to become proliferative again $[34,93]$.

Transcription factors regulating skeletal muscle differentiation.

A well orchestrated gene transcription program involved in the regulation of skeletal muscle differentiatilon has been described in recent years (Fig. $1.3)[6,25,26,33,38,39,59,69,93,94,102,103,113,116,117,137]$. The MyoD family of myogenic transcription factors controls the process of skeletal muscle

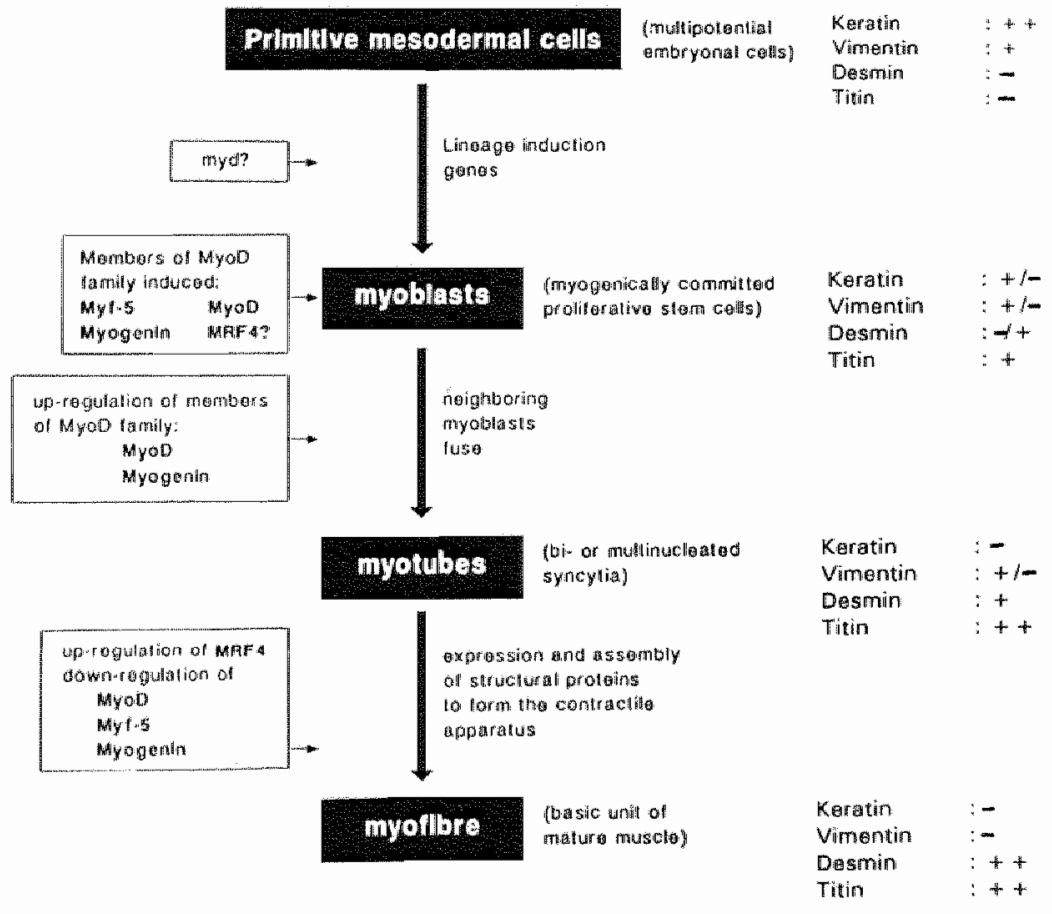

Figure 1.3: Interactions of myogenic regulatory factors with other positive and negative regulatory factors in the transcriptional activation of musclespecific genes. (Adapted from Dias, 1994 [26]). 
differentiation during development. This family includes MyoD (myf-3) $[24]$, myogenin (myf-4) [31,140], myf-5 [11] and MRF-4 [100] lalso known as herculin [83] or myf-6 [12]). Members of this family share a sequence for a basic-helix-loop-helix (bHLH) regulatory motif, needed for the formation of either hetero- or homodimers and DNA binding. Heterodimers of members of this family bind to the consensus DNA sequence CANNTG, the so-called E-box.

The bHLH regulatory motif confers both transcriptional activation of muscle specific genes and inhibition of cell growth, either through collaboration with the ubiquitous E2A gene products (the HLH-proteins E12 and E47) [17,88], and/or with the retinoblastoma gene product $(p R B)[52]$. Activity of the MyoD family proteins can be suppressed by various factors, including the peptide growth factors FGF [71] and TGF- $3[15,79]$, immediate early gene products (Fos, Jun and Myc $[9,68,72,84] 1$, other oncogene products such as Ras $[64,70]$, Src [35], the Id protein [8], and neural innervation [17].

The picture that has emerged over the last decades shows that a complex constellation of homeobox containing proteins are involved in the development of differentiation factor gradients that govern myogenesis. In somitogenesis, such gradients were found in the anterior-posterior, the dorso-ventral as well as in the medio-lateral direction of the individual somites, and in the limb buds $[56,87,98]$. Subtile differences of these concentration gradients determine temporal and spatial aspects of the onset of myogenesis, as well as the type of skeletal muscle cell (fast or slow twitch) that will be formed.

The use of gene-knockout animal models has suggested a degree of functional redundancy. For instance, inactivation of either MyoD [101] or myf-5 [13] has no effect on muscle development, whereas inactivation of both genes results in an absolute lack of muscle cells. This indicates that there is a high degree of compensation between transcription factors. In contrast, the inactivation of myogenin alone results in mice with a gross deficiency of mature muscle $[55,89]$.

The muscle-specific intermediate filament protein desmin is up-regulated during skeletal muscle development. The activation of the transcription of the desmin gene is mediated by the muscle-specific determination factors MyoD and myogenin [126,127 (and references therein)]. Analysis of the promoter-region of the desmin gene revealed that a single E-box, that is located in this domain, is essential for desmin promotor activity $[73 \mathrm{~b}, 126,127]$.

\section{The sarcomere, the contractile unit of striated muscle.}

The major components of the sarcomere are the thick filaments $(15 \mathrm{~nm})$, consisting of myosin, and the thin filaments $(8 \mathrm{~nm})$, containing actin, tropomyosin, and troponin. These filaments are organized in a regular pattern in the direction of movement of the sarcomere. The intra-sarcomeric localization of thick and thin filaments results in the typically striated pattern seen in light and electron microscopy. In this pattern one can easily distinguish the M-line, the $\mathrm{H}$. band, the A-band (thick filaments), two I-bands (thin filaments), and two Z-lines per sarcomere. The positions of the major sarcomere components are indicated 
in the schematic drawing in figure 1.4 .

The thick and the thin filaments can actively slide along each other, thus providing the contractile force of striated muscle. Several structural proteins are invalved in supporting these contractile elements. $a$-Actinin anchors the thin filaments to the central body of the Z-discs, lacated at both ends of the sarcomere $[53,121]$. In addition to $a$-actinin and actin, the Z-disc and its direct surroundings contain several other lanchoring) proteins like CapZ (B-actinin) [20], vinculin [118], spectrin [92] and ankyrin [92] (reviewed by Small [110]). The Z-line associated intermediate filament protein desmin links the sarcomeres to each other. Intermediate filament-associated proteins related to the Z-line are synemin [49], paranemin [14], filamin [46\|, and plectin [86].

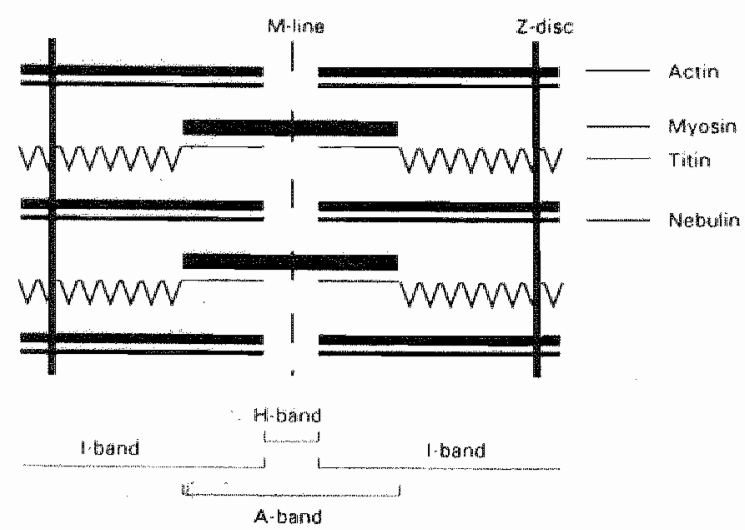

Figure 1.4: Schematic representation of the sarcomere.

(Adapted from Schaart. 1994 [107])

In skeletal muscle the length of the thin filaments is regulated by the ruler protein nebulin $[123,124]$. A second ruler protein is titin, that is present in both skeletal and cardiac muscle $[123,124]$. This high molecular weight protein (with isoforms from 2400 to $3000 \mathrm{kDa}$ ) [80] spans half the length of the sarcomere, determines the length of the thick filaments and anchors them to the $Z$-line. The "elastic" amino-terminal domain of titin, anchored to the Z-line, provides the flexibility to contracting sarcomeres, but also prevents the sarcomeres from overstretching. The "rigid" carboxy-terminal part, located in the $\mathrm{M}$-line region of the sarcomere, determines the length of the thick filaments. Myosin is attached to titin in association with C-protein [67] and H-protein [41]. The composition of the $M$-line is not known in detail, but several components of this region, such as M-protein [51,115], myomysin [5, 19,50], skelemin [99] and a $190 \mathrm{kDa}$ protein [135] have been described. 


\section{Cardiac muscle.}

General characteristics.

Cardiac muscle is a highly specialized form of involuntary striated muscle, with a cellular structure resembling skeletal muscle. The contractile apparatus is also composed of sarcomeres, of which the organization is similar to those of skeletal muscle, although cardiac sarcomeres do not contain nebulin as a ruler protein for thin filaments. Cardiac muscle cells contain only one or two centrally located nuclei. The cells are connected to each other by complex structures, referred to as the intercalated discs. These contain fascia adherens, desmosomes and gap junctions, which are the structures that connect the cells to each other. They enable the cardiac muscle cells to communicate and to coordinate contractions [62].

\section{Embryological origin and development.}

The heart originates from the laterall plate mesoderm and is the first functional organ in the developing embryo. In the ventrally located splanchnopleure of the coelomic pericardial cavity, cardiac primordia develop bilaterally. They form primitive heart tubes that subsequently fuse medially and develop into the four chamber heart.

During embryological development mesodermal cells differentiate into myoepicard cells, that are located around the primitive heart tubes. These myoepicard cells develop into myoblasts, which differentiate into muscle cells of the myocard, and into the mesothelial cells of the epicard. Differentiating cardiac myoblasts do not fuse into syncythia but interact at the intercalated discs. Differentiating myoblasts branch and attach to the cells in the longitudinal direction of the myofiber, as well as to laterally located neighbouring cells. As a result, cardiac myofibers are interconnected in a branched network, that enables them to generate well-coordinated, pulsatile motions during the wave-like contraction of the heart.

Induction and regulation of heart muscle cell differentiation is poorly understood. No equivalent of the MyoD-family of skeletal muscle-specific transcription factors, nor any other master transcriptional regulator, has been detected yet $[27,125]$. Recently, murine transgene and gene-targetting technologies have been applied to study the role of mammalian transcription factors in wivo $[29,65]$. Studies in transgenic mice have produced evidence for homeobox genes responsible for murine heart development $[1,23,74]$, and for a crucial role of retinoic acid [114]. Some muscle transcription factors (MEF-2 $148,60,73 a, 97$, 142], TEF $\mathbb{1}[36,63]$, MNF [7]) were found to be expressed in the early stages of both skeletal muscle and myocard development, but only two myocardial cell specific transcription factors have sofar been identified. The transcription factors Nkx $2.5[16,58,74]$ and GATA-4 $[61,85]$ are expressed predominantly in the heart-anlagen. The absence of other master regulators in the heart may be compensated by the interaction between tissue restricted factors (Nkx 2.5, GATA-4), striated muscie transcription factors (MEF-2, TEF-1, MNF) and ubiquitous factors $(E 12, E 47$, Id) [27]. The interaction of these factors may also 
be important to stabilize these cells in their differentiated state [27].

\section{Smooth muscle.}

General characteristics.

Smooth muscle, consists of narrow, tapering cells, each with a centrally located nucleus. This type of muscle is present in the walls of the viscera and hence is often referred to as wisceral or involuntary muscle. Smooth muscle cells (SMC) that are located in the vascular system are smaller than the SMC in other parts of the vertebrate body. SMC normally exhibit relatively slow contractions, that can be maintained for long periods without continuous stimulation. The contraction of SMC is the result of a "sliding mechanism" of 12-16 nm thick myosin filaments and $5-7 \mathrm{~nm}$ actin fillaments [62]. The organization of these myofilaments is not as regular as in striated muscle cells, although they are orientated in the direction of contraction. The thin actin filaments are anchored to dense bodies. These a actinin-rich, ovoid-shaped structures are located at the cell membrane or in the cytoplasm, and can be compared to the Z-lines of striated muscle $[28,62,110]$. The dense bodies have been described to link the contractile apparatus to the intermediate filament cytoskeleton [110].

\section{Embrvological origin and development.}

Smooth muscle is derived from the embryonic mesenchyme, is primarily mesodermal in origin and develops in association with connective tissue. The main seat of smooth muscle is the lining of the digestive tract. Certain other siltes, such as the ducts of glands associated with the gut, the bladder, the trachea and bronchi, are outgrowths of this tract. Most of these aforementioned smooth muscle cells are derived from the lateral mesoderm [45]. Additional loci of smooth muscle cells, independent of the gut, include the wall of circulatory vessels, genital organs, and other, rather specialized, tissues. The available evidence on the embryological origin of vascular SMC indicates that the majority of these cells is derived locally. That is, when an organ primordium is invaded by endothelium, the primordium itself contributes the SMC coat to the developing vessels $[108,109]$. Therefore, it is possible that different SMC have distinct functional properties due to different embryological origins. In developing arteria SMC are confined to the tunica media. Proliferation and differentiation during the formation of arterial walls appears to be controlled by locally activated autocrine and/or paracrine mechanisms present in the cells of the growing arterial wall [108,109]. When structural maturation proceeds, SMC lose their ability to proliferate $[22,47]$ as well as their fibroblast-like appearance, and form abundant myofilaments $(44,90,111]$. SMC proliferation, migration and differentiation in the tunica media of the large blood vessels is largely completed at birth $[30,75,108,109]$. The SMC in the postnatal tunica media can dedifferentiate and regain their ability to proliferate and migrate, for example to contribute to the formation of the tunica intima or to an intimal thickening, either as a response to changes in hemodynamics or as part of an arteriosclerotic lesion $[96,112]$.

The molecular mechanisms involved in smooth muscle differentiation during 
embryonical development have not yet been described, in part due to their heterogeneity in origin. Myogenic transcription factors that are exclusively expressed during development have not been identified sofar, neither for the vascular, nor for the non-vascular cells. However, the growth arrest homeobox gene gax, whose expression in adult is largely confined to cardiovascular tissues, has been described [138; and references therein]. This gene is expressed at its highest level in quiescent cells, and locks these cells in their differentiated state. Gax is down-regulated in response to platelet-derived growth factors or serum growth factors. This enables the transition of differentiated, contractille SMC to proliferative SMC, for example in response to endothelial denudation by balloon angioplasty [138].

Cytoskeletal and structural proteins in muscle cells.

Different sets of muscle-specific proteins occur at different stages of myogenesis, both during in vivo and in vitro differentiation of skeletal, cardiac and smooth muscle cells $[4,6,32,33,37,40,54,105,106,119,120,121,123,128$ $132,136,139]$. Four groups of elements have been recognized as being important for the structural organization of the contractile apparatus of these muscle cells:

1) the myofilaments,

2) the ruler proteins,

3) the intermediate filament proteins,

4) the junctional complexes.

1) The myofilaments: expression and distribution of myosin and actin isoforms. A wide range of actin-based motile systems, with large differences in their level of structural organization, is found in nature. One extreme is the highly organized striated muscle cell with its highly ordered and stable arrangement of filaments, specialized for rapid contractions. As mentioned before, an actin- and myosinbased sliding mechanism enables these contractions. The other side of the spectrum is represented by the non-muscle cells, like fibroblasts, whose movements depend on the continuous assembly and disassembly of less organized actin filaments $[110)$. The level of organization of myofilaments in SMC is somewhere inbetween these two extremes, but contractions are also based on actin/myosin sliding mechanisms. Actin and myosin are amongst the most studied structural components in muscle cells because they provide the contractile potentiality. Tissue- and stage-specific isoforms of these proteins have been identified in muscle cells. Embryological studies have revealed that the distribution of isoforms of actin and myosin in developing muscle is different from the adult pattern. During differentiation isoform switches occur, replacing for example smooth muscle-specific $a$-actin with sarcomeric $a$-actin $[10,76,77$, $78,81,139]$. Similar isoform switches have been observed under pathological conditions $[2,3,82]$. 
2) The ruler proteins: templates for the assembly of sarcomeres.

In cross-striated muscle, the ruler proteins titin and nebulin determine the length of the myofilaments, organize the longitudinal orientation of myofilaments within the sarcomeres, and anchor these filaments to the Z-lines [123,124]. The function of these high molecular weight proteins, as well as the constituents of both the $Z$-line and the M-line, have been described above. Titin is a very early marker of striated muscle cells, and is the first protein displaying a cross-striated staining pattern during myogenesis. This indicates that titin is one of the first proteins to be organized in the developing sarcomere. It has been suggested that the formation of the titin "scaffold" is necessary for organizing the other components of the contractile apparatus.

Ruler proteins for smooth muscle cells, analogous to titim and nebulin, have sofar not been identified. The absence of ruler proteins may be directly related to the lower degree of organization of the contractile apparatus of SMC. However, the presence of a structural protein involved in for example the maintainance of the longitudinal orientation of the cells may be expected. Proteins of high molecular mass (400-700 kDa) have already been demonstrated to occur at low abundancy in smooth muscle cells, but they have not been further characterized as yet $[110\rfloor$.

\section{3) The intermediate filament proteins.}

Depending on developmental stage, tissue or species, variable combinations of the intermediate filament proteins (IFP) desmin, vimentin and keratins have been described in vertebrate muscle cells. Keratins are the first IFP expressed in embryogenesis, in epithelioid cells that are sitill multipotential in nature $\llbracket 122]$. Since myogenic cells can co-express three types of IFP, desmin and vimentin can be found next to keratin during early stagles of myogenesis $[66,134]$. During further differentiation keratin expression decreases and is superceded by expression of the other IFP (fig. 1.2). Vimentin is found in replicating myoblasts or in early stages of development when desmin is still undetectable [42]. In general, the vimentin filaments gradually disappear and the concentration of desmin increases during the differentiation process, both in vivo and in vitro $[37$, $105,119,127,131$. Desmin is the primary, muscle-specific IFP of mature muscle cells 11101 , although there are clear exceptions to this rule, as examplified by the expression of vimentin in vascular SMC [91,95]. SMC containing desmin or vimentin, or a mixture of the two, can exist next to each other, reflecting either a different function, differences in embryological origin, or different combinations of regullatory signals during differenthation.

The function of IFP in muscle is not clear vet. In mature striated muscle cells desmin is associated with the Z-lines, and is probably involved in anchoring the myofilaments. In SMC desmin filaments are longitudinally orientated and closely associated with the dense bodies, but do not seem to be involved in the spatial organization of these structures [28].

4) The junctional complexes. 
The membrane of muscle cells is important as an anchorage site for the contractile structures, for transmitting force, for cell adherence, and for communication between cells. Within the membrane of muscle cells "junctional domains" and intervening "non-junctional domains" can be distinguished. Several junctional complexes have been defined, according to their location, morphology and composition lreviewed by Small [110] and by Van der Ven [133]). In brief. smooth muscle cells contain adherens junctions, calveolae rich domains and dense bodies. Skeletal muscle contains costameres, myotendinous junctions, and neuromuscular junctions, whereas dystrophin and dystrophin associated proteins are also involved in the interaction between the cytoskeleton and the extracellular matrix [141]. Intercalated discs are specific for cardiac muscle, and comprise desmosomal and adherens junctions. At present little is known about the cytoskeleton underlying the non-junctional regions $[110]$.

Outline of this thesis:

Aspects of muscle cell differentiation have been studied in the three types af muscle, i.e. skeletal, cardiac, and smooth muscle, which exhibit a varying degree in the organization of their contractile structures. The degree of cellular organization is clearly related to the developmental stage and functional aspects of these tissues. The studies were performed using in vitro and in vivo model systems, i.e. differentiating muscle cell cultures and different stages of rabbit heart development, respectively. Furthermore, adult tissues of various origin and derived from different species were included. In these systems cell differentiation was monitored by the expression and (re-lorganization of structural components of the contractile apparatus, the cytoskeleton, as well as cell junctions.

In striated muscle cells the high molecular weight protein titin has been suggested to play a keyrole in the organization of the sarcomere. The first pait of this thesis elaborates on the universal role of titin in sarcomere formation (chapters 2-5). The expression and reorganization of titin was studied both in differentiating cultured muscle cells (chapters 2 \& 3 ) and during muscle development in vivo (chapters $4 \& 51$. Changes in the supramolecular organization of titin and its integration into the sarcomere during in vitro skeletal muscle cell differentiation have been described in more detail (chapter 3). The expression and organization of titin is described in relation to other musclle specific proteins, intermediate filaments and desmosomes. The sequence of events in the process of expression and organization of these components is species-dependent, both in vivo (chapter 2) and in wivo (chapter 4). A role for the keratin filaments is suggested in the developmental rearrangement of desmosomes into the intercalated discs (chapter 5 ).

The second part of this thesis describes the characterization and cloning of a smooth muscle specific, cytoskeletal protein that is exclusively expressed in differentiated cells, both in normal and in pathologicall SMC. A correlation between the expression of this protein and the contractile labour of (vascular) smooth muscle cells is suggested (chapters $6 \mathrm{\&} 7$ ). 


\section{Heterences}

1. Amacher SL, Buskin JN, Hauschka SD. Identification of a muscle creatine kinase enthancer A.T-rich site binding factor as oct-1. $\%$. Biol. Chem. 1995/n press.

2. Ausma J. Schaart $G$. Thone $F$, Shivalkar B, Flameng $W$, Depré $C$, Vanoverschelde $J$ L. Ramaekers F, Borgers M. Chronic ischemic viable myocardium in man: Aspects of dedifferentiation. Cardiovasc. Pathol. 1995:4:29-37.

3. Babai $F$, Musevi-Aghdam J, Schurch W, Royal A, Gabbiani G. Coexpression of alpha-sarcomeric, alpha-smooth muscle actin and desmin during myogenesis in rat and mouse embryos. Differentiation 1990:44:132-142.

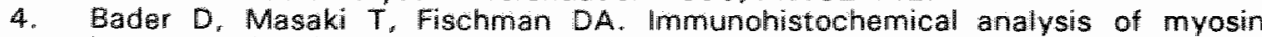
heavy chain during avian myogenesis in vivo and in vitro. 4 . Cell Biol. $1982 ; 95: 763-770$.

5. Bahler M, Walliman T. Eppenberger HM. Myofibrillar M-bands proteins represent constituents of native thick filaments, frayed filaments and and bare zone assemblages.. J. Muscle Res. Cell Motil. 1985;6:783-800.

6. Bandman E. Contractile protein isoforms in muscle development. Dev. Biol. $1992 ; 54: 273-28$.

7. Bassel Duby R, Hernandez MD. Gonzalez MA, Krueger JK, Williams RS. A 40killodalton protein binds specifically to an upstream sequence element essential for muscle-specific transcription of the human myoglobin promoter. Mol. Cell. Biol. 1994;12:5024-5032.

8. Benezra R, Davis RL, Lockshon D. Turner DL, Weintraub $H$. The protein Id: A neglative regulator of helix-loop-thelix DNA binding proteins. Cell 1991:61:49-59.

9. Bengal $E$, Ransone $L$, Scharfmann $R$, Dwarki $V J$, Tapscott SJ, Weintraub $H$, Verma IM. Functional antagonism between c-Jun and MyoD proteins: A direct physical association. Cell 1992:68:507-519.

10. Bentley Lawrence J, Taneja K. Singer RH. Temporal resolution and sequential expression of muscle-specific genes revealed by in situ hybridization. Dev. Biol. $1989 ; 133: 235-246$.

11. Braun T, Buschhausen-Denker $G$, Bober $E$, Tannich $E$, Arnold HH. A novel human muscle factor related to but distinct from MyoD 1 induces myogenic conversion in 10T $1 / 2$ fibroblasts. EMBO J. 1989;8:701-709.

12. Braun $T$, Bober $E$, Winter $B$, Rnsenthal $N$, Arnold $H H$. Myf-6, a new member of the human human gene family of myogenic detemination factors. EMBO $J$ $1990: 9: 821-831$.

13. Braun T, Rudnicki MA, Arnold $H H$, Jaenisch $\mathbb{R}$. Targeted inactivation of the regulatory gene Myf-5 results in abnormal rib development and perinatal death. Cell 1992;71:369-382.

14. Breckler J, Lazarides E. Isolation of a new high molecular weight protein associated with desmin and vimentin filaments from avian embryonic skeletall muscle. J. Cell Biol. 1982:92:796-806.

15. Brennan TJ, Edmondson DG, Li L. Olson E. Transforming growth factor beta represses the actions of myogenin through a mechanism independent of DNA. binding. Proc. Natl. Acad. Sci. USA 1991;88:3822-3826.

16. Buckingham ME. Muscle: the regulation of myogenesis. Curr. Opin. Genet. Dev. $1994,4: 745-751$.

17. Buonanno A, Apone L. Morasso Mil, Beers R, Brenner HR, Eftimie R. The MyoD family of myogenic factors is regulated by electrical activity: isolation and characterization of a mouse Myf-5 cDNA. Nucleic Acids Res. 1992;20:539-544.

18. Buskin JN, Hauschka SD. Identification of a myocyte nuclear factor that binds to the muscle specific enhancer of the mouse creatine kinase gene. Mol. Cell Biol. $1989: 9: 2627-2640$.

19. Carlsson E, Grove BK, Walliman T, Eppenberger HM, Thornell L-E. Myotibrillar Mband proteins in rat skeletal muscles during development. Histochemistry $1990 ; 95: 27 \cdot 35$

20. Casella IF, Craig SW, Maack DJ, Brown AE. Cap Z(36/32), a barbed end actincapping protein, is a component of the Z-line of skeletal muscle. J. Cell Biol. 
$1987: 105: 371-379$

21. Chevallier A. Kieny M, Mauger A, Sengel $P$. Developmental fate of the mesoderm in the chick embryo. In: Ede DA. Hincholiffe JR, Balls M (eds). Cambridge University Press, Cambridge, 1977, pp. 421-432.

22. Chou R-GR, Stromer MH, Robson RM, Hulatt TW. Assembly of contractile and cytoskeletal elements in developing smooth muscle cells. Dev. Biol. $1992 ; 149: 339-348$.

23. Csersjesi P. Lilly B, Brysan $L$, Wang $Y$, Sassoon DA, Olson EN. MHox: a mesodermaly restricted homeodomain protein that binds an essential site in the muscle creatine kinase enhancer. Development 1992;115:1087"1101.

24. Davis $R L$. Weintrawb $H_{*}$ Lassar AB. Expression of a single transfected cDNA converts fibroblasts to myoblasts. Cell 1987:51:987-1000.

25. Davis $R L$, Cheng P.F. Lassar $A B$, Weintraub $H$. The MyoD DNA binding domain contains a recognition code for muscle-specific gene activation. Celf $1990 ; 60: 733-746$.

26. Dias $P$, Dilling $M$, Houghton $P$. The molecular basis of skeletal muscle differentiation. 1994:11:3-14.

27. Doevendans PA, van Bilsen M. Transcription factors and the cardiac gene programme (mini-review). Int. J. Biochem. Cell Biol.: $\| n$ press

28. Draeger A, Amos WB, lkebe M, Small JV. The cytosikelletal and contractile apparatus of smooth muscle: contraction bands and segmentation of the contractile elements. J. Cell Biol. 1990:111:2463-2473.

29. Dzau JD, Gibbons $\mathrm{GH}$. Vascular remodeling mechanisms and imlications. $\mathcal{H}$ Cardiovasc. Pharmacol. 1993:21(suppl. 1):1-5.

30. Dzau VJ, Gibbons GH, Koblika BK, Lawn RM, Pratt RE. Genetic models of human cardiovascular disease. Circulation 1995,91:521-531.

31. Edmondson DG, Olson EN. A gene with homology to the myc similarity region of MyoD1 is expressed during myogenesis and is sufficient to activate the muscle differentiation program. Genes Dev. 1989:628-640.

32. Epstein HF. Fischman DA. Molecular analysis of protein assembly in muscle development. Science 1991;251:1039-1044.

33. Epstein HF, Bernstein SI. Genetic approaches to understanding muscle development. Dev. Biol. 1992*154:231-244.

34. Evans SM, Tai L-J, Tan VP. Newton CB, Chien KR. Heterokaryons of cardiac myocytes and fibroblasts reveal the lack of dominance of the cardiac muscle phenotype. Mol. Cell. Biol. 1994; 14:4269-4279.

35. Falcone $G$, Alema $S$, Tato $F$. Transcription of muscle-specific genes is repressed by reactivation of pp60v-sic in postmitotic quail myotubes. Mol. Cell Biol. $1991 ; 11: 3331-3338$.

36. Farrance $\| K$, Mar JH, Ordahl CP. M-CAT binding factor is related to the SV40 enhancer binding factor, TEF-1. Biol. Chem. 1992;267:17234-17240.

37. Fischman DA. Myofibrillogenesis and the morphogenesis of skeletal muscle. In: Myology. Basic and Clinical. (Engel AG \& Banker BQ. Eds.), 1986,5-30. New York: McGraw-Hill.

38. Flucher BE. Structural analysis of muscle development: tranisverse tubulus, sarcoplasmic reticulum, and the triad. Dev. Biol. $1992 ; 154: 245-260$.

39. Funk WD, Ouelette M, Wright WE. Molecular biology af myogenic regulatory factors. Mol Biol. Med. 1991:8:185-195.

40. Fürst DO. Osborn M. Nave $R$. Weber $K$. Myogenesis in the mouse embryo: differential onset of expression of myogenic proteins and the involvement of titin in myofibril assembly. 1 . Cell Biol. 1989:109:517-527.

41. Fürst DO, Nave R. Osborm M, Weber K. Repetitive titin epitopes with a $42 \mathrm{~nm}$ spacing coincide in relative position with known $\mathrm{A}$ band striations also identified by major myosin-associated proteins. An immunoelectron-microscopical study on myofibrils. d. Cell Sci. 1989;94:119-125.

42. Gard DL, Lazarides $E$. The synthesis and distribution of desmin and vimentin during myogenesis in vitro. Cell 1980;19:263-275. 
43. Gauthier GF. The muscular tissue. In. Weiss L ledl. Cell and Tissue Biology - A textbook of histology. Urban Schwarzenberg. Baltimore/Munich, sixth edition $1988 \mathrm{pp} .257-278$

44. Gerity RG. Clif WJ. The aortic tunica media of developing rat. 1. Quantitatiwe stereological and biochemical analysis. Lab. Invest. 1975:32:585-600.

45. Gilbert SF. Developmental Biology, third edition, chapter 6: Early vertebrate development: Mesodem and endoderm. Sinawer Associates Inc, Sunderland. Massachusetts, $1991,00.201-205$.

46. Gomer RH. Lazarides E. The synthesis and deployment of filamin in chicken skeletal muscile. Cell 1981;23:524-532.

47. Gordon D, Schwartz SM. Cell proliferation in human atherosclerosis. Trends Cardiowasc. Res. 1991:1:24-28.

48. Gosset LA, Kelvin DJ, Strenberg EA, Olson EN. A new myocyte specific enhancer-binding factor that recognizes a conserved element associated with multiple muscle-specific genes. Mol. Cell. Biol. 1989;:9:5022-5033.

49. Granger BL. Lazarides $E$. Synemin: a new high molecular weight protein associated with desmin and vimentin filaments in muscle cells. Cell $1979 ; 22: 727-738$.

50. Grove BK, Kurer V, Lehner C, Doetschman TC, Perriard J-C, Eppenberger HM. A new 185,000-dalton skeletal muscle protein detected by monoclonal antibodies. J. Cell Biol. 1984;98:518524.

51. Girove BK. Cerny L, Perriard J-C. Eppenberger HM. Myomesin and M-protein: expression of two M-band proteins in pectoral muscle and during heart development. Cell Biol. 1985;101:1413-1421.

52. Gu W, Schneider JW, Condorelli G, Kaushal S, Mahdawi V. Nadal-Ginard $B$. Interaction of myogenic factors and the retinablastoma protein mediates muscle cell commitment and differentiation. Cell 1993;72:309-324.

53. Handell SE, Wang S-M. Greaser ML, Schultz E, Bulinski JC, Lessard JL. Skeletal muscle myofibrillogenesis as revealed with a monoclonal antibody to titin in combination with detection of the alpha- and gamma-isoforms of actin. Dev. Biol. $1989: 134: 35-44$.

54. Handel SE, Greaser ML, Schulz E, Wang S-M, Bulinski JC, Lin JJ J L Lessard JLL. Chicken cardiac myofibrillogenesis studied with antibodies specific for titin and the muscle and nonmuscle isoforms of actin and tropomyosin. Cell Tissue Res. $1991 ; 263: 419 \cdot 430$.

55. Hasty $\mathrm{P}$, Bradley A, Morris JH, Edmondson DG, Venuti JM, Olson EN, Klein WH. Muscle deficiency and neonatal death in mice with a targeted mutation in the myogenin gene. Nature 1993;364:501-506.

56. Hayashi $K$, Ozawa $E$. Myogenic cell migration from somites is induced by tissue contact with medial region of the presumptive limb mesoderm in chick embryos. Development 1995:121:661-669.

57. Hill CS, Duran $S$, Zhongxiang $L$, Weber $K$, Holtzer, $H$. Titin and myosin, but not desmin are linked during myofibrillogenesis in postmitotic mononuclear myoblasts. J. Cell Biol. 1986;103:2185-2196.

58. Hirmmelbauer $H$. Harvey RP, Copeland NG, Jenkins NA, Siver LM. Highresolution genetic analysis of a deletion on mouse chromosome 17 extending ower the fused, tufted, and homeobox Nkx2.5 loci. Mamm. Genome. $1994: 5: 814.816$.

59. Hinterberger TJ, Sassoon DA, Rhodes S., Konieczny SF. Expression of the muscle regulatory factor MRF4 during somite and skelletall myofiber development. Dev. Biol 1991;146:144-156.

60. Iannello RC. Mar $\mathrm{JH}_{*}$ Ordahl CP. Characterization of a promotor element required for transcription in myocardiall cells. J. Biol. Chem. 1991;266:3309-3316.

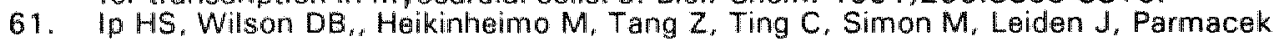
MS. The GATA-4 transcription factor transactivates the cardiac muscle-specific

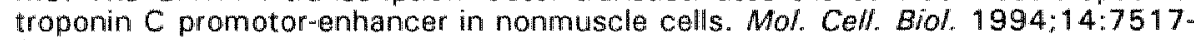
7526 . 
62. Junqueira LC, Carneiro J, Kelley RO. Basic Histology. Sixth edition, chapter 11: Muscle. Appleton \& Lange, Norwalk / San Mateo, USA, 1989.

63. Kariyama $K$, Karns LR. Simpson PC. An enhancer cone mement mediates stimulation of the rat betamyosin heavy chain promoter by an alpha 1 adrenergic agonist and activated beta-protein kinase $C$ in hypertrophy of cadiac myocytes. J. Biol. Chem. 1994:269:3775-3782.

64. Konieczny SF, Drobes BL, Menke SL, Taparowsky EJ. Inhibition of myogenic differentiation by the H-ras oncogene is associated with the down regulation of the MyoD1 gene. Oncogene 1989;4:473-481.

65. Kubalak S, Doevendans PA, Rockman H, Hunter JJ, Tanaka N, Ross $J$, Chien KA. Molecular analysis of cardiac muscle diseases via mouse genetics. In: Methods in molecular genetics, ed. Adolph KW, In press Orlando: Academic Press, 1995.

66. Kunuc K. Franke WW. Transient coexpression of desmin and cytokeratins 8 and 18 in developing myocardial cells of some vertebrate species. Differentiation $1988: 38: 177-193$.

67. Labeit $S$, Gautel M. Lakay A. Trimick J. Towards a molecular understanding of titin. EMBO A. 1992;11:1711-1716.

68. Lassar $A B$, Thayer MJ, Overell RW, Weintraub $H$. Transformation by activated ras or fos prevents myogenesis by inhibiting expression of Myod1. Cell $1989 ; 58: 659-667$.

69. Lassar AB, Davis RL, Wright WE, Kadesch $T$, Murre C, Vorovona A, Baltimore D, Weintraub $H$. Functional activity og myogenic HLH proteins requires heterooligomerization with E12/E47-like Proteins in vivo. Cell 1991:66:305-316.

70. Lewin B. Oncogenic conversion by regulatory changes in transcription factors. Cell $1991 ; 64: 303-312$.

71. Li L, Zhou J, James $G$, Heller-Harisson R, Czech MP, Olson EN. FGF inactivates myogenic helix-loop helix proteins through phosphorylation of a conserved protein kinase $C$ site in their DNA-binding domains. Cell 1992;71:1181-1194.

72. Li L. Chambard JC. Karin M. Olson EN. Fos and jun repress transcriptional activation by myogenin and MyaD: The amino terminus of Jun can mediate repression. Genes Dev. 1992;6:676-689.

73a. Li Z . Paulin D. Different factors interact with myoblast-specific and myotubespecific enhancer regions of the human desmin gene. $J$. Bial. Chem. $1993: 268: 10403-10415$.

73b. Li Z, Marchand $P$, Humbert J, Babinet C, Paulin D. Desmin sequence elements regulating skeletal muscle-specific expression in transgenic mice. Development $1993: 117: 947-959$.

74. Lints TJ, Parsons LM, Hartley L, Lyons I, Harvey RP. Nkx-2.5: a novel murine homeobax gene expressed in early heart progenitor cells and their myogenic descendants. Development 1993;119:419-431.

75. Lowell Langille $B$. Remodeling of developing and mature arteries: Endathelium, smooth muscle, and matrix. $\%$. Cardiovasc. Pharmacol. 1993:21 (suppl.11:11-17.

76. Lyons GE, Ontell M, Cox R, Sassoon DA, Buckingham, M. The expression of myosin genes in developing skeletal muscle in the mouse embryo. $J$. Cell Birol. 1990:111:1465-1476.

77. Lyons GE, Schaffino S. Sassoon DA, Barton P, Buckingham, M. Developmental regulation of myosin gene expression in mouse cardiac muscle. $d$. Cell Biral. $1990: 111: 2427-2436$.

78. Lyons GE. Buckingham ME, Mannherz HG. a-Actin proteins and gene transcripts are colocalized in embryonic mouse muscle. Development 1991:111:451-454.

79. Martin JF, Li L. Olson EN. Repression of myogenin function by TGF-beta 1 is targleted at the basic helix-loophelix motif and is independent of E2A products. J. Biol. Chem. 1992:267:10956-10960.

80. Maruyama, K. Connectin, an elastic protein of striated muscle. Biophys. Chem. $1994: 50: 73-85$.

81. Masaki $T$, Bader DM, Reinach FC, Shimizu T, Obinata $T$, Shafiq $S A$, Fischman DA. Monoclonal antibody analysis of myosin heavy chain and the protein 
isoforms during myogenesis. In: Pearson, M., Epstein, H., Kaufman and Garrels J.L. (eds). Molecular and cellular control of muscle development. Cold Spring Harbor Lab Press, $1982 ; 405-417$.

82. McHugh $K M$, Crawford $K$, Lessard $J L$. A comprehensive analysis of the developmental and tissue-specific expression of the isoactin multigene familly in the rat. Dew. Biol. 1991:148:442 458.

83. Miner JH, Wold BJ. Herculin, a fourth member of the MyoD family of imyogenic regulatory genes. Proc. Natl. Acad. Sci. USA 1990;87:1089-1093.

84. Miner JH. Wold BJ. C.MYc inhibition of MyoD and myogenin-initiated myogenic differentiation. Mol. Cell Biol. 1991;11:2842-2851.

85. Molkentin JD, Kalvakolanu DV, Markham BE. Transcription factor GATA-4 regulates cardiac muscle-specific expression of the alpha-myosin heavy-chain gene. Mol. Cell Biol. 1994:1:4:4947-4957.

86. Mugurama M. Kobayashi K. Fukuzawa T, Ohashi K. Maruyama K. A new 220,000 dalton protein located in the Zlines of vertebrate skeletal muscle. $J$. Biochem. 1981:1981-1984.

87. Minsterberg $A E$. Lassar $A B$. Combinatorial signals from the neural tube, floor plate and notochord induce myogenic bHLH gene expression in the somite. Development 1995;121:651-660.

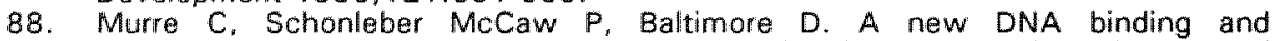
dimerization motif in immunoglobulin enhancer binding, daughterlless, MyoD, and myc proteins. Cell 1989:56:777-783.

89. Nabeshima $Y$, Hanaoka K, Hayasaka M, Esumi E, Li S, Nonaka I, Nabeshima $Y$. Myogenin gene disruption results in perinatal lethallity because of severe muscle defect. Nature 1993;364:532-535.

90. Nakamura $H$. Electronmicroscopic study of prenatal development of the thoracic aorta in the rat. Am. J. Anat. 1988;181:406-418.

91. Nanaev AK, Shirinsky VP. Birukov KG. Immunofluorescent study of heterogeinety in smooth muscle cells of human fetal vessels using antibodies to myosin, desmin and vimentin. Cell Tissue Res. 1991;266:535-540.

92. Nelson WJ, Lazarides E. Goblin lankyrin in striated muscle: identification of the potential membrane receptor ofor erythroid spectrin in muscle cells. Proc. Nat/. Acad. Sci. USA. 1984;81:3292-3296.

93. Olson EN, Brennan TJ, Chakraborty $T$, Cheng $T-C$, Cserjesi $P$, Edmondson $D$, James G, Li L. Molecular control of myogenesis: antagonism between growth and differentiation. Mol. Cell. Biochem. 1991;104:7-13.

94. Olson EN. Interplay between proliferation and differentiation within the myogenic lineage. Dev. Biol. 1992;154:261-272.

95. Osborn M, Caselitz J, Püschel, Weber $K$. Intermediate filament expression in human vascular smooth muscle and in arteriosclerotic plaques. Virchows Arch. A $1987 ; 411: 449-458$.

96. Pauletto $\mathbb{P}$. Sarzani $R$, Rappelli $A$, Chiavegato A, Pessina AC, Sartore $S$. Differentiation and growth of vascular smooth muscle cells in experimental hypertension. Am. J.Hypertension 1994;7:661-674.

97. Pollock R. Treisman R. Human SRF-related proteins: DNA-binding properties and potential regulatory targets. Genes Dev. 1991;5:2327-2341.

98. Pourquie 0 . Coltey $M$. Bréant C. Le Douarin NM. Control of somite patterning by signals from the lateral plate. Proc. NaU. Acad. Sci. USA 1995;92:3219-3223.

99. Price MG. Skelemins: cytoskeletal proteins located at the periphery of M-discs in mammalian striated muscle. J. Cell Biol. 1987:104:1325-1336.

100. Rhodes SJ, Konieczny SF. Identification of MRF4: a new member of the muscle regulatory factor gene family. Genes Dev. 1989;3:2050-2061.

101. Rudnicki MA, Braun T, Hinuma S, Jaenisch R. Inactivation of MyoD in mice leads to up-regulation of the myogenis HLH gene Myf-5 and results in apparently normal muscle development. Cell 1992:71:383-390.

102. Sartore S. Scatena M, Chiavegato A, Faggin E, Giuriato L, Pauletto P. Myosin isoform expression in smooth muscle cells during physiological and pathological 
vascular remodeling. J. Vasc. Res. 1994:31:61-8*

103. Sassion DA, Lyons $G$. Wright WE, Lin $V$, Lassar $A$. Weintraub H. Buckingham $M$. Expression of two myogenic regulatory factors myogenin and MyoD1 during mouse embryogenesis. Nature 1989:341:303-307.

104. Sassoon DA. Myogenic regulatory factors: dissecting their role and regulation during vertebrate embryogenesis. Dev. Biol. 1993:"156:11-23.

105. Schaart $G_{v}$ Viebahn $C$, Langmann $W$, Ramaekers FCS. Desmin and titin expression in early postimplantation mouse ambryos. Development $1989: 107: 585-596$.

106. Schaart $G$. Pieper FR, Kuijpers HJH, Bloemendal H. Ramaekers FCS. Baby hamster kidney (BHK-21/C13) cells can express striated muscle type proteins. Differentiation 1991;46:105-115.

107. Schaart G. Expression and organization of sarcomeric constituents during muscle cell differentiation. Thesis Maastricht, 1994.

108. Schwartz SM. Heimark RL. Majesky MW. Developmental mechanisms underlying pathology of arteries. Phwsiol. Rev. 1990;70:1177-1209.

109. Schwartz SM, Liaw L. Growth control and morphogenesis in the development and pathology of arteries. J. Cardiovasc. Phamacol. 1993;21 (suppl.1):31-49.

110. Small JV, Fürst DO. Thornell L-E. The cytoskeletal lattice of muscle cells Review. Eur. J. Brochem. 1992;208:559-572.

111. Sprinkle DJ. Subbiah MTR. Studies on aorta during development. I. Fetal rabbit aorta under ex vivo and in vitro conditions: Rapid changes in smooth muscle cell phenotype, cell proliferation and cholesterol content with organ culture. Atherosclerosis 1987;67:57-59.

112. Stary HC. Composition and classification of human atherosclerotic lesions. Virchows Archiv. A 1992;421:277-290.

113. Stockdale FE. Myogenic cell lineages. Dev. Biol. 1992;154:284-298.

114. Studer M, Popperl $H$, Marshall $H$, Kuroiwa $A$, Krumlauf $R$. Role of a conserved retinoic acid response element in rhombomere restriction of Hoxbm 1 . Science $1994: 265: 1728-1732$.

115. Strehler EE, Carlsson E, Eppenberger HM, Thornell L-E. Ultrastructural localization of $M$-band proteins in chicken muscle as revealed by combined immunocytochemistry and ultramicrotomy. $J$. Mol. Biol. 1983:166:141-158.

116. Tapscott SJ, Davis RL. Thayer MJ, Cheng P.F. Weintraub H, Lassar AB. MyoD 1: a nuclear phosphoprotein requiring a myc homology region to convert fibroblasts to myoblasts. Science $1988 ; 242: 405-411$.

117. Tapscott $\mathrm{SJ}$, Lassar $\mathrm{AB}$. Davis $\mathrm{RL}$. Weintraub H. 5-Bromo-2'-deoxyuridine blocks myogenesis by extinguishing expression of Myod 1. Science 1989:245:532-536.

118. Terracio L, Simpson DG. Hilenski L. Carver W, Decker RS, Vinson N, Borg TK. Distribution of vinculin in the $Z$-disk of striated muscle: analysis by scanning laser microscopy. J. Cell. Physiol. 1990;145:78-87.

119. Tokuyasu KT, Maher PA, Singer SJ. Distributions of vimentin and desmin un developing chick myotubes in vivo. I. Immunofluarescence study. $J$ Cell Bial. $1984 ; 96: 1961-1972$.

120. Tokuyasu KT, Maher PA. Immunocytochemical studies of cardiac myofibrillogenesis in earty chick embryos. I. Presence of immunofluorescent titin spots in premyofibril stages. $\int$. Cell Biol. 1987a:105:2781-2793.

121. Tokuyasu KT, Maher PA. Immunocytochemical studies of cardiac myofibrillogenesis inearly chick embryos. II. Generation of a-actinin dots within titin spots at the time of the first myofibril formation. J. Cell Biol. $1987 \mathrm{~b} ; 105: 2795-2801$.

122. Traub P. Intermediate filaments. A review. Springer, Berlin Heidelberg New York Tokyo. $1985, p$ p.2-17.

123. Trinick $J$. Understanding the functions of titin and nebulin. FEBS Lett. $1992 ; 307: 44-48$.

124. Trinick, J. Titin and nebulin: protein rulers in muscle? Trends Biochem. Sci. $1994 ; 19: 405-409$. 
125. Van Bisen M, Chien KR. Growth and hypertrophy of the heart: lowards an understanding of cardiac specific and inducible gene expression. Cardiovasc. Res. $1993: 27: 1140-1149$.

126. Van de Klundert FA, Jansen HJ, Bloemendal H. A proximal promoter ellement in the hamster desmin upstream regulatory region is responsible for actiwation by myogenic determination factors. $\%$ Biol. Chem. 1994:269:220-225.

127. Van de Klundert FA. Desmin and vimentin. Regulation of gene expression. Thesis Nijmegen, 1995.

128. Van dar Loop FTL, Schaart G, Langmann W, Ramaekers FCS, Viebahn $C$. Expression and organization of muscle specific proteins during the early developmental stages of the rabbit heart. Anat. Embryol. 1992;185:439-450.

129. Van der Loop FTL. Schaart G, Langmann H. Ramaekers FCS, Viebahn Ch. Rearrangement of intercellular junctions and cytoskeletal proteins during rabbit myocard development. Eur. W. Cell Biol. 1995;68:62-69.

130. Van der Loop FTL, van Eys GJJM, Schaart G. Ramaekers FCS. Titin expression as an early indication of heart and skeletal muscleu differentiation in vitro. Developmental re-organization in relation to cytoskeletal constituents. Muscie Ries. Cell Motil. : in press.

131. Van der Ven PFM, Schaart G, Jap PHK, Sengers RCA, Stadhouders AM, Ramaekers FCS. Differentiation of human skeletal muscle cells in culture: maturation as indicated by titin and desmin striation. Cell Tissue Res. $1992: 270: 189-198$

132. Van der Ven PFM "Schaart G, Croes HJS, Jap PHK, Ginsel LA, Ramaekers FCS. Titin aggregates associated with intermediate filaments align along stress fiberlike stuctures during human skeletal muscle cell differentiation. $J$. Cell Sci. $1993 ; 106: 749-759$.

133. Van der Ven PFM. Molecular morphollogy of developing healthy and diseased skeletal muscle. Thesis Nimegen, 1995, pp. 16-21.

134. Van Muijen GNP. Ruiter DJ. Warnaar SO. Coexpression of intermediate filament polypeptides in human fetal and adult tissues. Lab. Invest. 1987:57:359-369.

135. Vinkemeier U, Obermann W. Weber K. Fürst DO. The globular head domain of titin extends into the center of the sarcomeric M-band. CDNA cloning, epitope mapping and immunoelectron microscopy of two titin-associated proteins. $J$. Cell Sci. 1993;106:319-330.

136. Wang SM, Greaser ML, Schultz E, Bulinski JC, Lin JJC, Lessard JL. Studies on cardiac myofibrillogenesis with antibodies to titin, actin, tropomyosin, and myosin. I. Cell Biol. 1989:107:1075-1083.

137. Weintraub $H$, Davis $R$. Tapscott $S$, Thayer $M$, Krause $M$, Benezra $R$, Blackwell $K$, Turner D, Rupp R, Hollenberg $S$, Zhuang $Y$, Lassar A. The MyoD gene family: nodal point during specification of the muscle cell lineage. Science $1991 ; 251: 761-766$.

138. Weir L, Chen D. Pastore C. Isner JM. Walsh K. Expression of gax, a growth arrest homeobox gene, is rapidly down-regulated in the rat carotid artery during the proliferative responce to balloon injury. $J$. Biol. Chem. 1995:270:5457-5461.

139. Wessels A. Vermeulen JLM, Virágh SZ, Kálmán F, Lameirs WH, Moorman AFM. Spatial distribution of "tissue-specific" antigens in the developing human heart and skeletal muscle. I1. An immunohistochemical analysis of myosin heavy chain axpression patterns in the embryonic heart. Anat. Rec. 1991:229:355-368.

140. Wright WE. Sassoon DA, Lin VK. Myogenin, a factor regulating myogenesis, has a domain homologous to MyoD. Cell 1989;56:607-617.

141. Yoshida M, Ozawa E. Glycoprotein complex anchoring dystrophin to sarcolemma. J. Biochem. 1991;108:748-752.

142. Zhu H, Garcia AV, Ross RS, Evans SM, Chien KR. A conserved 28-base-pair element (HF-1) in the rat cardiac myosin light-chain 2 gene confers cardiac specific and alpha-adrenergic-inducible expression in cultured neonatal rat myocardial cells. Mol. Cell. Biol. 1991:11:2273;-2281. 
Titin expression as an early indication of heart and skeletal muscle differentiation in vitro. Developmental re-organization in relation to cytoskeletal constituents.

Frank T.L. van der Loop, Guillaume J.J.M. van Eys, Gert Schaart and Frans C.S. Ramaekers.

Journal of Muscle Research and Cell Motility: In press.

Established myogenic cell lines of different species and tissue origin have been used to study expression and organization of muscle-specific proteins during differentiation. Furthermore, primary cultures of rat myocard cells were used to examine these same processes during dedifferentiation. In particular, we were interested in the general mechanism that underlies the changes in the supramolecular organization of titin during in vitro myogenesis. It became obvious that in the differentiating muscle cell cultures the redistribution of desmin, actin and myosin in a typical, differentiation state dependent fashion, always showed a certain delay when compared to titin. The sequence of changes in the assembly of cytoskeletal and sarcomeric structures observed during differentiation of the cell lines was reversed during the process of dedifferentiation in cultured rat myocard cells. These results all indicate that titin is an early marker of myogenic differentiation, both in vivo and in witro, and that the typical re-organization of this giant molecule is independent of species or muscle cell type.

\section{Introduction}

During muscle cell development, intermediate filament proteins and musclespecific constituents are expressed in a differentiation-stage dependent pattern. In addition, the synthesis of such components and their mutual association occur 
in a time dependent sequence of well defined steps (Fürst et al, 1989; Van der Loop et al., 19921.

One of the muscle specific proteins that occur in an early phase of muscle cell differentiation is titin. This high-molecular weight protein titin is striated muscle specific and the first sarcomeric protein detected in the process of myofibrillogenesis in vivo (Tokuyasu \& Maher, 1987; Fürst et al., 1989; Schaart et al., 1989; Van der Loop et al., 1992). Titin is an elongated and flexible molecule that extends from the Z-line up to the $M$-line, and is considered to play an important part in the supramolecular organization of the sarcomere (Fulton \& Isaacs, 1991; Trinick, 1992; Maruyama, 19941.

The intermediate filaments (IF) that are found in early stages of myogenesis consist of vimentin. Vimentin filaments are found in replicating myoblasts and early stages of myotube development when desmin, the intermediate filament protein found in all differentiated muscle cell types, is still undetectable (Gard \& Lazarides, 1980; Traub, 1985). During the differentiation process the level of expression of desmin increases and desmin filaments are formed, while vimentin expression decreases (Barbet et al, 1991; Fischman, 1986; Pieper et al., 1987; Schaart et al., 1989; Tokuyasu et al., 1984; Van der Loop et al.. 1992; Van der Ven et al., 1992). In cardiac and skeletal muscle, a reorganization of desmin from a filamentous into a cross-striated pattern occurs when myoblasts differentiate into mature myotubes. One of the functions of desmin IF may concern the transport of newly synthesized titin moleculles to stress fiber-like structures (SFLS), consisting of non-muscle actin isoforms and localized beneath the sarcolemma (Van der Ven et al., 1993).

Both myosin and actin display a change of isoform expression during cardiac and skeletal muscle development (Lompré et al., 1984; De Groot et al., 1989; De Jong et al., 1990). For example, the region specific switch of expression of the $\alpha$-and $B$-cardiac isoforms of the myosin heavy chain is characteristic for the developing heart (Lyons et al., 1990). During skeletal muscle development, at least three myosin heavy chain isoforms are expressed consecutively (Whalan et al., 1990). A similar pattern unrolls for actin. A multigene family encoding at least six distinct actin isoforms has been found in mammals (Vandekerckhove et al., 1978, 1981,1986; Buckingham et a/., 1985). Members of this multigene family have been shown to be specific for the type and developmental stage of muscle cells. Actin isoforms that are not specific for fully differentiated striated muscle cells, such as $\alpha$-smooth muscle actin, can be found in many striated muscle cell types at the stage of postmitotic myoblasts (Babaii et al., 1990; Bochaton-Piallat et al., 1992; Rudzicka et al., 1988; Woodcock-Mitchell et al., 1988).

Myogenic cell cultures may provide model systems to investigate changes in expression and organization of intermediate filament proteins and other musclespecific constituents during muscle cell development and to examine their role in the construction and maintenance of the contractile apparatus. Myogenic cell lines proliferate and remain undifferentiated when kept subconfluently in a medium enriched for growth factors. Serum depreviation and high cell density 
induce fusion of individual myoblasts into multinucleated myotubes. Differentiation can thus be induced and monitored by the appearance of a particular set of proteins, such as titin, desmin, and specific isoforms of myosin and actin (Yaffe \& Saxel, 1977; Vandekerckhove et al., 1978, 1981, Buckingham et al. 1985). Cell lines can contribute to the understanding of the underlying processes of musclle cell differentiation, although it is not completely clear to which degree this reflects the in vivo situation.

The majority of earlier studies on the expression and re-organization of musclespecific and intermediate filament proteins was performed in primary cultures of chick cardiac muscle cells (Holtzer et al., 1990; Handel et al. 1991; Lu et al. 1992; Maruyama et al. 1994), although some studies in mammallan cells were performed (Nag et al. 1986). In most of these studies embryonic hearts were enzymatically dispersed and the recovery of the sarcomere organization in cardiac myofibers was monitored. Undifferentiated of fully dedifferentiated cells were only sporadicially exploited. These studies provided insight in the build up of sarcomeric structures, but they gave limited information in the very early stages of (avian) muscle differentiation. Besides, there may be differences in striated muscle development between avian and mammalian organisms.

In this study the expression and the re-organization of titin from dot-like aggregates into a cross-striated pattern is investigated in proliferative and differentiating musclle cells. Mammalian cell lines of different origin imuscle type, species ; are used to determine whether or not a general mechanism underlies these changes in the supramolecular organization of titin. A number of additional muscle-specific constituents are used as markers to disicuss the value of established cell lines and primary cultured rat myocard cells as models for myogenic development.

\section{Materials and methods}

\section{Cell lines used in this study}

1) BHK-21/C13 baby hamster kidney cells express desmin, titin and muscle specific tropomyosin and are therefore considered to be of muscle origin lFrank et al., 1982; Quinlan \& Franke, 1982; Schart et al., 1991; Stoker Macpherson, 1961). The BHK-21/C13 cells used in the present study were obtained from Flow Laboratories Urvine, UK).

2) C2C12 mouse skeletal muscle cells (Blau et al. 1983) have been subcloned from the C2 line isolated by Yaffe and Saxel (1977). The induction of cell fusion and myotube formation in confluent cultures of C2C12 cells by a switch of culture medium has been described by Bains et al. (1984).

3) The H9C2(2-1) cell line has been derived from embryonic BDIX rat heart tissue. The cells propagate as randomly orientated myoblasts and, upon reaching confluency and a medium switch, organize into linear, parallel arrays and form multinucleated tubular structures (Kimes \& Brandt, 1976). H9C2(2-1) cells were 
obtained from the American Type Culture Collection (ATCC CRL-1446; Rockville, Maryland, USA?.

4) A primary culture of rat myocard cells obtained from neonatal Lewis-rats (University of Limburg, Centralized Experimental Animal Facilities, Maastricht, The Netherlands). Hearts were isolated, minced into small pieces and trypsinized according to Dlugosz et al. (1984) and Vitadello et al. (1990). Myogenic cells were selected by taking advantage of differences in adherence properties of fibroblasts, endothelial cells and myocard cells to cell culture plastics. After 2 passages, the muscle cells were used for immunofluorescence studies or Western blotting-analysis.

\section{Culturing conditions}

All cell lines were seeded at low densities in Eagle's modified minimum essential medium (EMEM: Flow Laboratories, Irvine, UK) containing 15\% heat-inactivated Fetal Clone (HyClone Laboratories, Logan, Utah, USA) or $15 \%$ heat-inactivated fetal calf serum (Gibco, Paislev, UK), 2 mM L-glutamin (Serva, Heidelberg, FRG), $1 \%$ non-essential amino acids (Flow), $10 \mathrm{mM}$ HEPES (Flow) and $0,05 \mathrm{mg} / \mathrm{ml}$ gentamycin (AUV, Cuijk, The Netherlands). After the cells had grown to near confluency, elongation and fusion of the cells was induced by culturing for 2-4 days in EMEM plus 2\% normal horse serum (Flow). This method has been described for C2C12 cells by Bains et al. (1984), and appears also to work for the other two established cells lines. Cells were kept in a humidified incubator at $5 \% \mathrm{CO}_{2}$ and $37^{\circ} \mathrm{C}$.

\section{Indirect immunofluorescence assays}

For indirect immunofluorescence assays cells were grown on glass coverslips. The coverslips were washed in phosphate buffered saline (PBS; $137 \mathrm{mM} \mathrm{NaCl}$, $13 \mathrm{mM} \mathrm{Na}_{2} \mathrm{HPO}_{4} \cdot 2 \mathrm{H}_{2} \mathrm{O}, 3 \mathrm{mM} \mathrm{KH} \mathrm{PO}_{4} ;$ Merck, Darmstadt, FRG) at $4{ }^{\circ} \mathrm{C}$. The cells were fixed by dipping the coverslips three times for $1 \mathrm{~s}$ in cold

$\left(-20^{\circ} \mathrm{C}\right)$ methanol, followed by one dip for $1 \mathrm{~s}$ in acetone $\left(-20^{\circ} \mathrm{C}\right)$. Slips were airdried at room temperature for $10 \mathrm{~min}$ and stored at $-20^{\circ} \mathrm{C}$ until use. After thawing, the fixed cells were air-dried again before they were immunostained using either a single- or a double-label procedure. Both procedures started with a 30 min incubation with a primary antibody, followed by PBS-washes 13 times; 5 min each). An anti mouse $\mathrm{lg}$-subclass specific conjugate with either fluorescein isothiocyanate (FITC), tetramethyllhodamine isothiocyanate (TRITC) or Texas red (TXRd), or an anti rabbit-lg conjugate with FITC or TxRd (Nordic Immunochemicals, Tilburg, the Netherlands; Southern Biotechnology Associates Inc., Birmingham, Alabama, USA) was used as a secondary antibody. In the double-label procedure these immunostaining steps were repeated with a second primary antibody of a different lg-subclass. After the labeling procedure glass slips were mounted in Mowiol (Hoechst, Frankfurt, FRG; Osborn \& Weber, 1982) and examined using a Zeiss microscope equipped with epifluorescence illumination optics.

The characteristics of the antibodies used in this study are listed in Table 2.1. 
Table 2.1: Antibodies used in this study.

\begin{tabular}{|c|c|c|c|c|}
\hline & Antigen & Dilution & $\begin{array}{l}\text { lgSub- } \\
\text { class }\end{array}$ & $\begin{array}{l}\text { Reference } \\
\text { [Origin] }\end{array}$ \\
\hline 9010 & Tittin & $\begin{array}{l}I F: 1: 10 \\
I B: 1: 50\end{array}$ & $\begin{array}{l}\text { mouse } \\
\lg M\end{array}$ & $\begin{array}{l}\text { Wang at al, } 1985 \\
\text { Greaser et al. } 1989 \\
\text { Handel et al. } 1989 . \\
\text { [see footnotel }\end{array}$ \\
\hline DER-11 & Desmin & $I F: 1: 10$ & $\begin{array}{l}\text { mouse } \\
\text { lgGi }\end{array}$ & $\begin{array}{l}\text { Debus et al, } 1983 \\
\text { [DAKO A/S, Gllostrup, } \\
\text { Denmark] }\end{array}$ \\
\hline $\mathrm{RD} 301$ & Desmin & $\begin{array}{l}\text { IF: : ud } \\
\text { IB: } 1: 5\end{array}$ & $\begin{array}{l}\text { mouse: } \\
\operatorname{lgG} 2 \mathrm{~b}\end{array}$ & Pieper et at. 1987. \\
\hline pDes & Desmin & IF: $: 1: 40$ & $\begin{array}{l}\text { rabbit } \\
\text { serum }\end{array}$ & $\begin{array}{l}\text { Ramaekers et al, } 1985 \\
\text { [Euro-Diagnostica, Apeldoorn, } \\
\text { The Nethenlands] }\end{array}$ \\
\hline RV 202 & Vimentin & $\begin{array}{l}\text { IF: ud } \\
\text { IB: } 1: 10\end{array}$ & $\begin{array}{l}\text { mouse } \\
\operatorname{lgG1}\end{array}$ & $\begin{array}{l}\text { Fiamaekers et al. "1987; } \\
\text { Viebahn ef at. } 1988 .\end{array}$ \\
\hline RV203 & Vimentin & IF: Ld & $\begin{array}{l}\text { mouse } \\
\text { loGi }\end{array}$ & Schaart et af, 1989. \\
\hline pVim & Vimentin & IF: $1: 10$ & $\begin{array}{l}\text { rabbit } \\
\text { serum }\end{array}$ & Ramaekers et at, 1983. \\
\hline$a S r-1$ & $\begin{array}{l}\text { a-Striated Musclie } \\
\text { Actin }\end{array}$ & IF: $1: 10$ & $\begin{array}{l}\text { mouse } \\
\| g G 2 a\end{array}$ & $\begin{array}{l}\text { Skalli et al., } 1988 \text {. } \\
\text { [A generous gift from } \\
\text { Prof. G. Gabbiani, Geneva. } \\
\text { Swwitserland]. }\end{array}$ \\
\hline$a \mathrm{Sm}-1$ & $\begin{array}{l}\text { a-Smooth Muscle } \\
\text { Actin }\end{array}$ & $\begin{array}{l}\text { IB: } \\
1: 5000\end{array}$ & $\begin{array}{l}\text { mouse } \\
\| g G 2 a\end{array}$ & $\begin{array}{l}\text { Skalli et al, } 1986 . \\
\text { [A generous gift from } \\
\text { Prof. G. Gabbiani, Geneva, } \\
\text { Switserland]. }\end{array}$ \\
\hline MF20 & $\begin{array}{l}\text { Striated } \\
\text { Muscle Myosin }\end{array}$ & $\begin{array}{l}\text { IF: } 1: 10 \\
\text { IB: } 1: 10\end{array}$ & $\begin{array}{l}\text { mouse } \\
\text { log } 2 b\end{array}$ & $\begin{array}{l}\text { Bader et al, } 1982 \text {; } \\
\text { Masaki et al, } 1982 \text {. } \\
\text { [seie lootnote] }\end{array}$ \\
\hline
\end{tabular}

IF, IB: antibody dilutions used for immunofluorescence and immunoblotting assays, respectively. (ud $=$ undiluted culture supernatant).

Note: The monoclonal antibodies $9 \mathrm{D} 10$ and MF20 were obtained from the Developmental Studies Hybridoma Bank, maintained by the Department of Pharmacology and Molecular Sciences, Johns Hopkins University School of Medicine, Baltimore, MD, USA, and the Departement of Biology, University of lowa, lowa City, IA, USA, under contract NO1-H3D-6-2915 from the NICHD. 
Gel electrophoresis and immunoblotting

Cells were harvested from $75-\mathrm{cm}^{2}$ culture flasks (80-90\% confluency) with a rubber policeman, washed in PBS, centrifuged for $10 \mathrm{~min}$ at $3000 \mathrm{~g}$, and extracted in PBS containing $0.5 \%$ Triton $X-100$ (BDH), 5 mM EDTA (Merck), 5 mM EGTA (Boehringer, Mannheim, FRG), $0.4 \mathrm{mM}$ phenylmethylsulphonyl fluoride (PMSF; Aldrich Chemie, Steinheim, FRG). After centrifugation (10 min at $3000 \mathrm{~g}, 0^{\circ} \mathrm{Cl}$, and washing with PBS, the pellet, containing the cytoskeletal fraction, was dissolved by boiling for $4 \mathrm{~min}$ in SDS-sample buffer (Laemmli, $1970)$.

One-dimensional gel electrophoresis was performed in a Mini Protean II Electrophoresis Cell (Bia-Rad Laboratories, Richmond, CA, USA) on 7.5\% polyacrylamide slab gels containing $0.1 \%$ SDS (7.5\%-AA gels; Laemmli, 1970). The gels were stained with Coomassie Brilliant Blue R250 (CBB; Gurr, Hopkins and Williams, Chadwell Heath, Essex, UKy for $30 \mathrm{~min}$ at $50^{\circ} \mathrm{C}$ for quantification of the amount of protein loaded per lane.

Western blotting was performed to identify muscle-specific and intermediate filament proteins. Equal amounts of totall protein extract, dissolved in sample buffer, were loaded on 7.5\%-AA gels. Electrophoretically separated proteins were transferred to nitrocellulose BA85 (Schleicher and Schüll, Dassel, FRG) by blotting for $1 \mathrm{~h}$ at $100 \mathrm{~V}$ in a cold buffer $\left(4^{\circ} \mathrm{C}\right.$ ) containing $25 \mathrm{mM}$ Tris (Merck), $192 \mathrm{mM}$ glycine (Merck), 0.02\% SDS (BDH) and 20\% methanol (Merck; Towbin et al. 1979). Identification of specific proteins was done by incubation of the blots with appropriately diluted antibodies (Table 2.1) and antibody binding was visualized with a slightly modified chemiluminescence method (Amersham International p.I.c., Buckinghamshire, U.K.; Schaart et al., 1993). Detection of more abundant muscle antigens was performed using a standard immunostaining procedure: horseradish peroxidase-conjugated secondary antibodies and staining with 4-chloro-1-naphthol (Merck) in $0.12 \%$ hydrogen peroxide (Merck). On a 4chloro-1-naphthol stained blot, several antibodies could be tested consecutively.

\section{Results}

Growth morphology of myogenic cell cultures

a) $B H K-21 / C 13, C 2 C 12$ and $H 9 C 2(2-1)$ - Cells from these three established cell lines were kept subconfluent in high serum medium to maintain proliferating. mononuclear myoblasts. In order to obtain differentiating cells, the cultures were grown to high cell density and a medium switch to law serum concentration was performed. Two to four days after the medium switch cells were fixed, immunostained (see below) and the stage of differentiation of the cells was based on morphological criteria. Four stages of differentiation are distinguished on basis of cell morphology:

1) The mononuclear, proliferating myoblasts retaining a polygonal shape;

2) The postmitotic, elongated mononuclear cells;

3) The fused di- and trinuclear elongated cells; 
4) Multinucleated, extremely elongated and non-proliferating cells, designated maturating myotubes.

The three different cell lines showed a similar time course for the different stages in the differentiation process, despite their wide range of growth rate in the myoblast stage.

The results of the immunofluorescence and immunoblotting studies of these cell lines are summarized in Table 2.2 and in figures $2.1,2.2,2.3,2.5$.

b) Primary cultured rat myocard cells - Primary cultures of rat myocard cells contained two cell types: undifferentiated non-contracting myoblasts and fully differentiated myocytes, that were still contracting after 2 to 5 passages. When the myocytes were in contact with each other the contractions appeared to be synchronic. Contraction activity decreased with the number of passages and in low cell density cultures.

The results of the immunofluorescence studies of these tissue cultures are summarized in Table 2.3 and figure 2.4 .
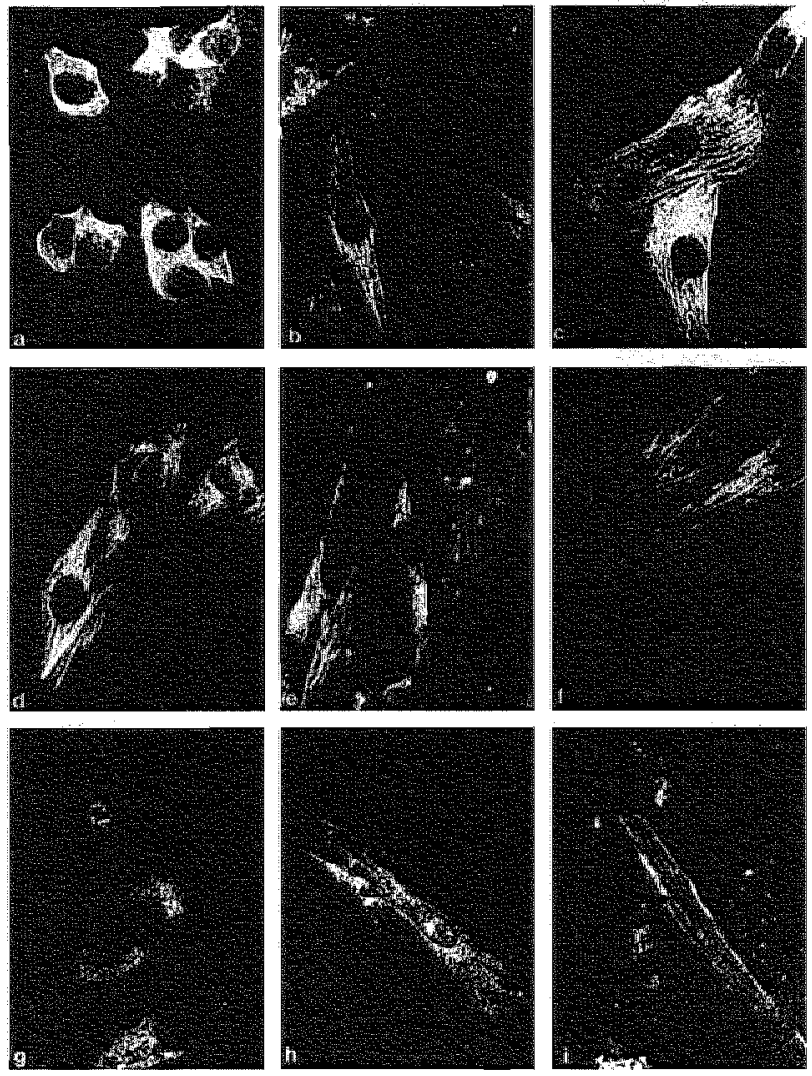

Figure 2.1:

Immunofluorescence micrographs showing the expression of titin in proliferating

mononuclear myoblasts $(a, d, g)$, wongating and fused muscle cells (b,c,e, h), and maturating myofibrils $(f, i)$ of culltured BHK-21/C 13 $(a-c), C 2 C 12(d-1)$ and H9C2(2-1) $(\mathrm{g}-\mathrm{i}) \mathrm{calls}$. Magnification: $\times 330$. 

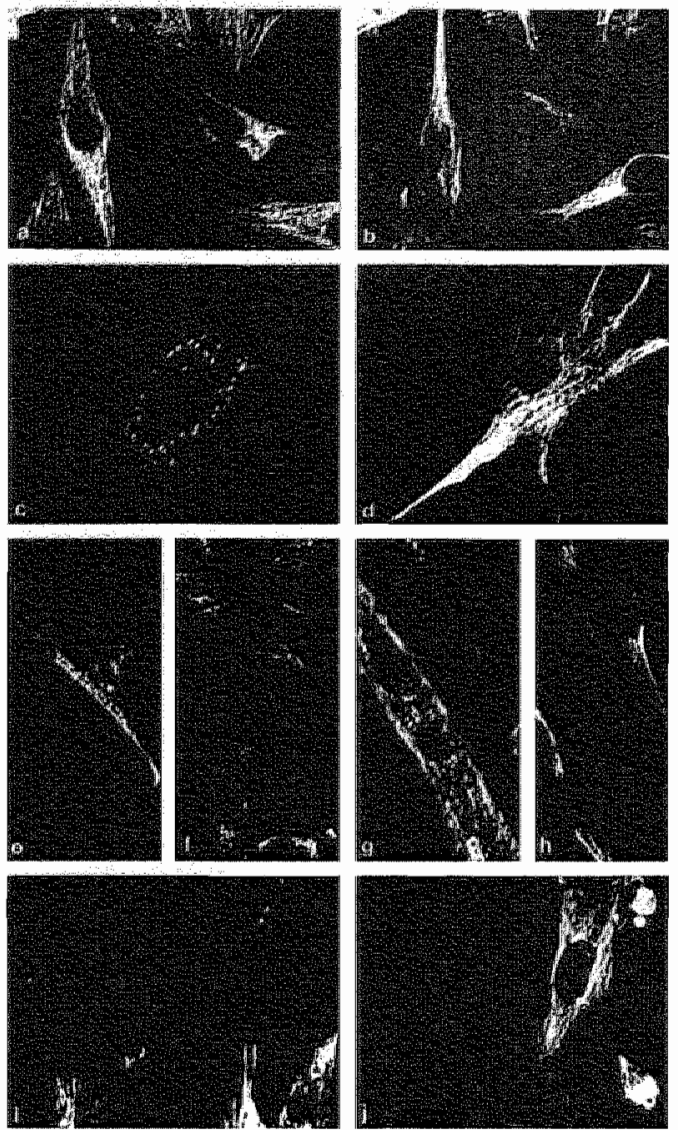

Figure 2.2: Double-label immunofluorescence micrographs of BHK-21/C13 (a-d) and $\mathrm{H} 9 \mathrm{C} 2(2-1)(\mathrm{e}-\mathrm{j})$ cells. Some BHK-21/C 13 cells co-express titin (a) and desmin (b).

Striated muscle-specific myosin dot-like aggregates (c) are colocalized with desmin filaments (d) some cells. In H9C2(2-1), titin positive cells $(e, g)$ are vimentin $(f, h)$ negative and vice versa. Desmin positive cells (j) are myosin (i) negative. Magnification: a-d x 330; ej $\times 270$.

Table 2.2: Summary of immunofluorescence and immunoblotting results of three in vitro differentiating myogenic cell lines compared to in vivo myogenesis in skeletal and cardiac muscle (see page 33).

Ledend for tate 2 2:

Diff

Diff DA

$\mathrm{DA}$

$\mathrm{F}$

SF/DA

SF/DA.S

S

+0 or +4

1..

if, 18

Pleferences
Diffus staining pattern

Diffuse staining with first Dot-ilke Aggregates

Dot tithe Agoregates

milangents

Stress Fiberlike structures with Dot-lice Aggregates

Stress Fobrike structures with Dotlike Aggregates, organizing into striation

Striations

Negatilitu

: Pasfitive or strongly positiwe, respectively

sporadically observad

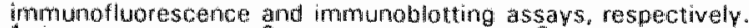

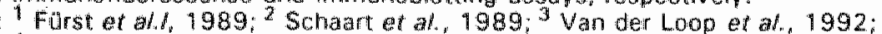

$4=$ myocard poripherally and centrally + . 
Prollerating

Mononuclear Mutolasts

IF IB
Nyocarot 2.3

YINENTIN

$B H K-21 / C H 3$

C2C 12

$\operatorname{HgC} 2(2 \times 1)$

Skevetal musclet

Myocaro 2.3

\section{ACTIN}

$B H K-2 \pi / C 13$

$\mathrm{C} 2 \mathrm{C} 12$

H:C $2(2-1)$

Shelatal musclet

Myocaro 3

\section{Str.m.- NYOSIN}

\section{$B H K-21 C 13$}

\section{$22 \mathrm{C} 12$}

H9C2(2-1)

Skeletal musche

Myocaro ${ }^{3}$
Diff $/ \mathrm{DA}$

F

Diff, DA

Diff, DA

DA

F

(DA), F

DA, P

(DAl, F

(DA), F

F

F

Fo

Dit/DA

DA (weak)

Difft

Diff, DA

F

DA, F

"F

Diff $-F$

Diff, DA

D. W ,
Elongaven and Fused Cells

IF

F. SFDA S

SFIDA F S

DA, SFIDA

$D A * S$

$D A_{i}, F,(S)$

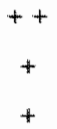

Maturating rroyotubas

F

$1 \mathrm{~B}$

IB $\quad$ IF $\quad H$

F. SFIOA $S$

$\mathrm{S}$

SF/DA $S$

$\mathrm{S}$

$F, S$

$\begin{array}{ccc}F & ++ & F \\ F & ++ & F \\ F & + & F \\ F & F S\end{array}$

$\begin{array}{ccc}\mathrm{F} & + & \mathrm{F} \\ \mathrm{F} & + & \mathrm{F} \\ \mathrm{F} & + & \mathrm{F} \\ . & & - \\ \mathrm{F} & & -\mathrm{F}^{3,4}\end{array}$

Diff SF/DA

Diff $\bullet F$

$+$

$++$

SF/DA $S$

$+$

$++$

$D A * S$

S

F

F

SF/OA F

SFDA

DIIt, DA $-F$

, Difl

DA $: S$

s

F, S 
Immunofhorescence assays

a) Baby Hamster Kioney celis (BHK-21/C13).

In the prolifertiting mononuclear myoblast stage of these cells titin first appears as dot-like aggregates next to a more diffuse localization throughout the cytoplasm (fig. 2.1a; table 2.2). The aggregates were found to be located along SFLS in elongated (fig. 2.1b) and fused cells. Occasionally, titin filaments were seen in elongated BHK-21/C13 cells. In elongated and fused cells, as well as in maturating myotubes titin dots appeared to be organized as beads on a string along stress fiber-like structures (fig. $2.1 \mathrm{c}$ ), before the organization changed into a cross-striated staining pattern. In contrast to this change in titin organization, the patterns observed for both desmin and vimentin remained filamentous in all stages inwestigated.

Double-label immunostaining reactions (fig. 2.2a,b) indicated that desmin (fig. $2.2 b)$ or vimentin filaments were present in elongated $\mathrm{BHK}-21 / \mathrm{C} 13$ cells with titin dots organized along SFLS (fig. 2.2a). It is obvious from comparison of
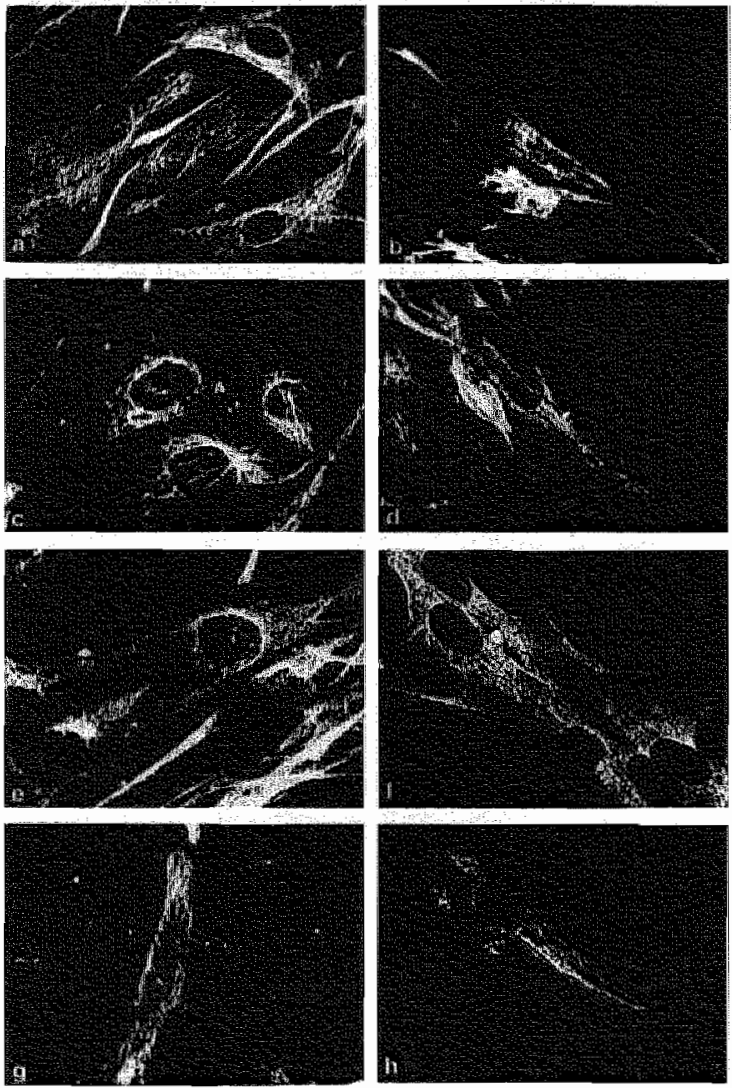

Figure 2.3:

Immunofluorescence micrographs showing the expression of muscle-specific proteins in cultured mouse skeletal muscle cells (C2C12). Desmin $(a, b)$ and vimentin $(c, d)$ filaments are present in polygonal and elongating cells. Striated muscle-specific actin。 present in a diffuse to dot-like fashion $(e, g)$, and striated muscle-specific myasin displayed filaments and crossstriations $(\boldsymbol{f}, \boldsymbol{h})$ in all stages, independent of the differentiation stage of the cells. Magnification: $\times 330$. 
figures $2.2 \mathrm{a}$ and $2.2 \mathrm{~b}$ that titin aggregates are not associated with $I F$, since their staining patterns are mutually exclusive to a large extent. In all stages investigated the expression lewel of striated muscle-specific myosin was low as compared to titin, desmin and vimentin, as deduced from immunofluorescence observations. Myosin dot-like aggregates and filaments were found in proliferating mononuclear BHK-21/C13 cells. Also these aggregates were organized along stress fibers in elongating cells, where myosin positive filaments were also observed. Myosin dot-like aggregates (fig. $2.2 \mathrm{c}$ ) were found in a small number of elongating cells (fig. 2.2d). Myosin aggregates and filaments remained present in maturating myotubes, but cross-striations were not found. In all stages, striated muscle-specific actin was also present, albeit at a relatively low level. A diffuse cytoplasmic staining pattern was observed, although in later stages of differentiation SFLS decorated with dots consisting of striated muscle specific actin, were encountered in a restricted number of maturating cells.

\section{b) Mouse Skeletal Muscle Cells (C2C12).}

The expression pattern and re-organization of titin in differentiating $\mathrm{C} 2 \mathrm{C} 12$ cells was less pronounced as compared to BHK-21/C13 cells, but similar observations were made: titin dot-like aggregates were present in the proliferating mononuclear myoblasts next to a more diffuse localization in the cytoplasm (fig. 2.1d). The dots appeared to be organized along SFLS in elongated and fused cells. Occasionally a filamentous titin staining pattern was found in elongated cells (fig. 2.1e). Titin displayed a striated pattern in maturating myotubes (fig. 2.1f). In all stages desmin (fig. 2.3a, b) and vimentin (fig. $2.3 \mathrm{c}, \mathrm{d}$ ) were in general present as filaments. Occasionally, desmin or vimentin dot-like aggregates were seen in proliferating cells.

A diffuse cytoplasmic staining pattern was found after staining the $\mathrm{C} 2 \mathrm{C} 12$ cells with the antibody against striated muscle actin, although actin positive filaments were occasionally encountered in maturating cells (fig. $2.3 \mathrm{e}, \mathrm{f})$. Striated musclespecific myosin was present at a relatively low level, as deduced from immunofluorescence observations. No stage specific staining patterns were found in $\mathrm{C} 2 \mathrm{C} 12$ cells, with some cells showing a filamentous pattern irrespective of their stage of differentiation (fig. $2.3 \mathrm{~g}, \mathrm{~h}$ ).

\section{c) Rat Heart Myoblasts (H9C2(2-1)).}

As in BHK-21/C13 and $\mathrm{C} 2 \mathrm{C} 12$ cells, titin first appears as a diffuse cytoplasmic localization in combination with dot-like aggregates in the proliferating $\mathrm{H} 9 \mathrm{C} 2 / 2$ 1) cells (fig. $2.1 \mathrm{~g}$ ). These aggregates were found along SFLS in elongated and fused cells (fig. $2.1 \mathrm{~h}$ ). In maturating myotubes titin gave a striated staining pattern (fig. 2.11). No titin filaments were observed in H9C2(2-1) cells. At any stage of development desmin and vimentin were organized in filaments. A large proportion of the cells displayed vimentin filaments, but desmin was expressed in only a minor cell population. When H9C2(2-1) cells were double immunostained, a small fraction of the proliferating cells showed both titin 
aggregates and vimentin filaments. Upon differentiation wimentin and titin staining beciame mutually exclusive in that titin positive cells were vimentin negarive (fig. $2.2 \mathrm{e}+\mathrm{h})$.

As compared to other constituents, striated muscle-specific myosin was present at a relatively low level and no stage-specific staining patterns were found. Some of the cells with desmin filaments expressed myosin in dotllike aggregates. In a small number of desmin negative cells, myosin dots were organized along SFLS (fig. 2.2i,j). The concentration of striated muscle-specific actim (oSr-1) was low and mostly observed as a diffuse cytoplasmic staining. although SFLS with striated muscle-specific actin aggregates were occasionally encountered in maturating cells.
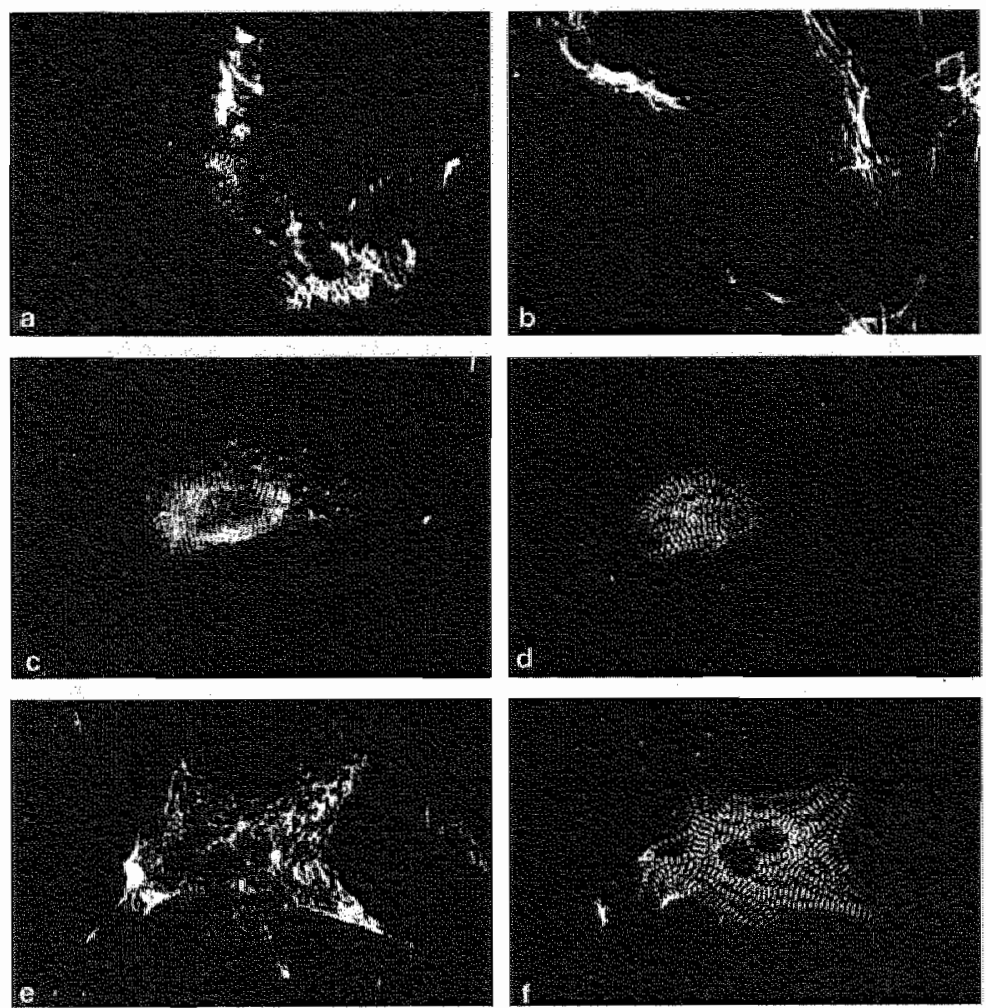

Figure 2.4: Double-label immunofluorescence micrographs of the expression of intermediate fhament- or muscle-specific proteins in cultured rat myocard cells (passage 2* 1 weak in culture). Myocytes (a,b) with desmin cross-striations (b), did not display vimentin filaments (a), whereas myoblasts, with vimentin filaments, were desmin negative. Double stained myocytes displayed titin cross-striation (d.f) co-expressed with desmin cross-striations (c) or filaments (e). Magnification: $\times 330$. 
Table 2.3: Summary of immunofluorescence results of cultured rat myocard cells.

\begin{tabular}{lcc}
\hline Antigen & \multicolumn{1}{c}{ Myoblasts } & Myocytes \\
\hline Titin & - & $\mathrm{S}$ \\
Desmin & - & $\mathrm{S}$ \\
Vimentin & F & \\
Actin & F & \\
Myosin & Diff & $\mathrm{S}$ \\
\hline
\end{tabular}

Abbreviations: see legend Table 2.2 (page 32).

d) Primary cultures of neonatal rat myocard cells.

The primary cultures of cell suspensions obtained from neonatal rat myocard splitted into two major cell populations, i.e. undifferentiated mononuclear myoblasts and fully differentiated, contracting myocytes, with only a small number of cells in between these stages.

Undifferentiated mononuclear myoblasts were identified by their expression of vimentin, present as filaments, but were negative for desmin (compare fig. $2.4 a_{\imath}$ b) and titin, although occasionally some weak and diffuse cytoplasmic titin reactivity was observed. When cells were seeded at high density, all cells displayed desmin filaments, indicating that the major part of fibroblasts was discarded by the procedure. Striated muscle specific actin filaments were found in a small number of cells.

Fully differentiated, contracting myocytes display titin in a cross-striated pattern during early passages (fig. 2.4d,f). Titin dot-like aggregates or filaments were not observed, neither in early nor in late passages. Desmin organization in early passages of these cells was in cross-striations (fig. $2.4 \mathrm{c}$ ), but changed into a filamentous pattern (fig. 2.4e) in later passages, while titin remained crossstriated (fig. 2.4f). In later passages, desmin negative cells were observed which still contained titin cross-striations. Contrary to the cell lines, primary cultured cells with titin cross-striations and desmin filaments or cross-striations, did not co-express vimentin filaments (fig. 2.4a,b). Myosin was organized in a crossstriated pattern in early passages. If cells were seeded at low density, preventing cell-cell contact, desmin and titin cross-striations were rapidly lost in early passages, with desmin changing into a filamentous pattern and titin being downregulated completely. Upon further passaging also desmin expression was lost. Myosin was down-regulated in such cultures, exhibiting filaments, followed by a cytoplasmic diffuse pattern. 
Attemps to induce myogenesis in the late passage cultures by a medium change as monitored by the re-expression of titin, indicated that these cells had lost the ability to differentiate.

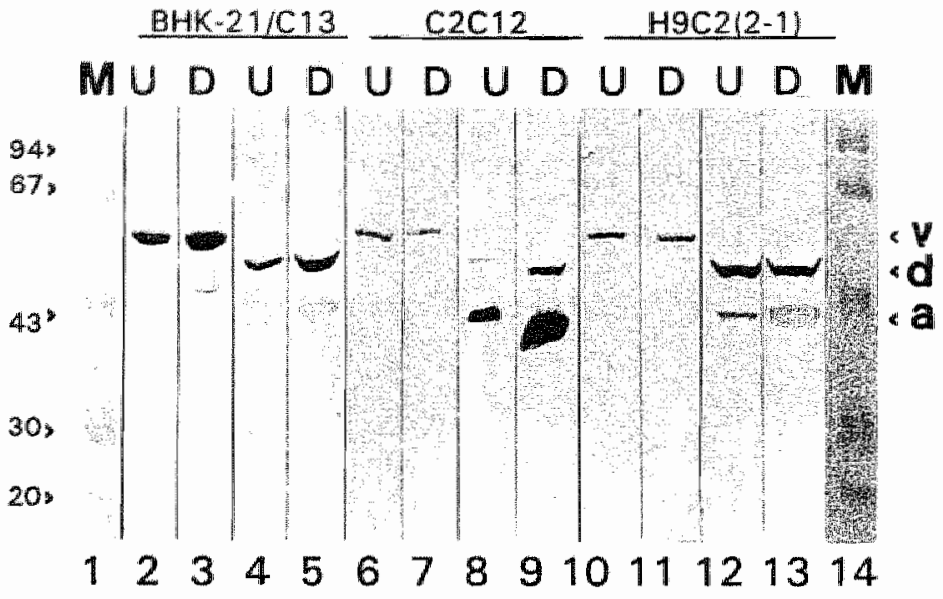

Figure 2.5: Immunoblotting results of the 3 cell lines. Triton $X-100$ extracts of populations of undifferentiating (U) and differentiating (D) cells were stained for vimentin (lanes $2,3,6,7,10,11$ ), or desmin and actin llanes $4,5,8,9,12,13$ ). $\mathrm{M}=$ Molecular weight markers (lanes 1,14 l: $v=$ vimentin; $d=$ desmin; $a=$ actin.

\section{Immunoblotting}

Immunoblotting experiments with cytoskeletal preparations of the undifferentiated and differentiated cultures showed that vimentin (fig. 2.5; llanes $2,3,6,7,10,11$ ) and desmin (lanes $4,5,8,9,12,13$ ) were always found in all three cell lines, although a differentiation stage dependent shift in the desmin concentration was observed in $\mathrm{C} 2 \mathrm{C} 12$ (compare lanes 8 and 9). Both $\mathrm{C} 2 \mathrm{C} 12$ and $\mathrm{H} 9 \mathrm{C} 2(2-1)$ expressed the smooth muscle type of actin in all stages (lanes $4,5,8,9,12,13)$, but expression of this type of actin in BHK-21/C 13 cells was only found in differentiated cells (compare lanes 4 and 5 ). The results of the Western blotting experiments are summarized in Table 2.2 .

At the time of the medium switch all cells in a population were in the same stage of differentiation. After induction, differentiation depended largely on the number of cell-cell contacts. Therefore, the number of differentiated cells differs between flasks. This prevents the application of an internal standard for quantification. 


\section{Discussion}

Cell lines and primary cultures of muscle cells provide model systems to study the expression and re-organization of muscle-specific proteins during myogenesis. Such cell cultures are easy to grow in large amounts and can be manipulated to differentiate. The re-organization of sarcomeric and cytoskeletal structures can be more easily visualized in monolayers as compared to tissue sections. In this study we have concentrated on the re-organization of titin during in vitro muscle cell differentiation.

Titim expression and re-organization in differentiating myogenic cell lines.

Although the three established muscle cell lines used in this study are derived from different species thamster, mouse, ratt and are of different tissue origins (kidney, skeletal muscle, heart) a general pattern for the expression and reorganization of titin during differentiation emerges. Titin firstly appears as dotlike aggregates, that organize along stress fiber-like structures during elongation and cell-fusion. In maturating myofibrils and myotubes a cross-striated pattern develops after a stage where titin dots are organized along SFLS as beads on a string. The titin patterns observed in the cell lines reflect those observed in wivo in skeletal and cardiac myogenesis (Fürst et al., 1989; Schaart et al., 1989; Van der Loop et al., 1992). The occurrence of titin filaments seen during in wivo mouse and rabbit myogenesis may be explained by a high density of titin aggregates organized along SFLS, as seen clearly in BHK-21/C13 cells (fig. 2.1c).

Although the cells went through several stages of development, the organization of desmin, striated muscle-specific actin and myosin did not demonstrate the differentiation-stage dependent staining patterns as observed in skeletal or myocardial muscle cells in vivo. The expression of the intermediate fillament protein vimentin is filamentous in all stages and was not lost with differentiation in vitro. It became obvious that in the differentiating muscle cell cultures the redistribution of desmin, actin and myosin in a typical, differentiation state dependent fashion, always showed a certain delay when compared to titin. In some cells, therefore, titin was already displayed when for example striated muscle myosin was not expressed yet. These results all indicate that titin is an early marker of myogenic differentiation, both in vivo and in vitro, and that the typical re-organization of this giant molecule is independent of species or muscle cell type.

From our observations it can also be concluded that, although myogenic cell lines can be induced to differentiate, the organization of muscle-specific proteins does not always reach the image resembling the end-stage of in wivo myogenesis. A major conclusion from this study is that the cell lines do not provide a complete model system for the differentiation of striated muscle cells, but that certain aspects of myogenesis, such as changes in the expression and 
horganization of titin during differentiation can be studied in detail using myogentc cell lines.

Thin expression and re-organization in dedifferentiating cultures of rat myocard cells.

The primary cultured rat myocytes retained morphological and physiological characteristics of muscle cells. The sequence of changes in the assembly of cytoskeletal and sarcomeric structures observed during differentiation of the cell lines was reversed during the process of dedifferentiation in rat myocard cells. Of the muscle specific proteins used as markers, desmin remained organized in a cross-striated pattern in myocytes for a restricted number of passages, and changed into fillaments in later passages. Titin was maintained in a cross-striated pattern for a considerably longer period than desmin. Eventually, titin organization is lost, which coincides with loss of in vitro contractility. Coexpression of titir and vimentin, a marker for undifferentiated cells, was never observed. The fact that cell density, contractility and presence of sarcomeric components is correlated indicates that the presence of cell-cell contacts, as observed in high cell density cultures, may be an important factor in the maintainance of the contractile applaratus of the myocytes.

The results of the primary cultured, dedifferentiating rat myocytes show that organizational changes of titin always run behind changes in the organization of other components such as desmin, actin and myosin, again indicating that titin is an early marker of differentiation.

Conclusions and future studies.

From our results it has become obvious that established myogenic cell lines can provide insight into the changes that titin undergoes during muscle cell differentiation. The order of expression and organization resembles the in wivo situation of this high molecular weight protein. In this respect, therefore cell lines are a reliable reflection of the in vivo development, and can now be used for studies involving the expression and organization of specific epitopes present along the titin molecule. Antibodies to such epitopes are available and have already shown that typical changes occur at the molecular level during muscle cell pathology (Ausma et al. 1995). Also studies on the expression of titin associated proteins and their differentiation dependent interactions with the titin molecule will become feasible using myogenic cell lines ".

The sequence of appearance of the muscle specific and intermediate filament proteins resembled in wivo muscle cell differentiation, but the organization of these proteins in the different stages displays differences as compared to in vivo. This study shows that nome of the cell lines investigated provides a complete model system for the differentiation of muscle cells. However, myogenic cell lines are valuable for the study of the role of particular proteins in defined stages of development.

If primary cultured myogenic cells are to be used for differentiation studies, it has to be considered that these cells seem to be de-differentiating (myocytes). 
and can not be induced to reach the fully differentiated stage again (myoolasts or fully dedifferentiated myocytes).

\section{References}

1. Ausma, J., Fürst, D., Thone, F, Flameng, W., Weber, K., Ramaekers, F. \& Borgers, M. (1995) Molecular changes of titin in left ventricular dysfunction as a result of chronic hibernation. J. Mol. Cell. Cardiol. 27, 1203-1212.

2. Babaï, F., Musevi-Aghdam, J., Schürch, W., Roval, A. \& Gabbiani, G. 1990/Coexpression of a-sarcomeric actin. a-smooth muscle actin and desmin during myogenesis in at and mouse embryos. I. Skeletal muscle. Differentiation 44, 132-142.

3. Bader, D., Masaki, T. \& Fischman, D.A. (1982) \|mmunohistochemical analysisi ofmyosin heavy chain during avian myogenesis in vivo and in vitro. $U$. Cell Brol. 95, $763-770$.

4. Bains, W., Ponte P., Blau, H. \& Kedes, L. (1984) Cardiac actin is the major actin gene product in skeletal muscle cell differentiation in vitro. Mol. Cell. Biol. 4. $1449-1453$.

5. Barbet, J.P., Thornell, L.-E. \& Butler-Brown, G.S. (1991) Immonocytochemical characterisation of two geneirations of fibers during the development of the human quadriceps muscle. Mech. Dev. 53, 3-11.

6. Blau, H., Chiu C.-P. \& Webster, C. (1983) Nucleoplasmic activation of human nuclear genes in stable heterocaryons. Cell 32, 1171-1180.

7. Bochaton-Piallat, M..L., Ropraz, P., Gabbiani, G., Santeusanio, G., Palmeiri, G., Schiaroli, S. \& Spagnoli, L.G. (1992) Actin isoforms and intermediate filament protein expression in human develloping skeletal muscle. B.A.M. 2, 83-87.

8. Buckingham. M.E. (1985) Actin and myosin multigene families: their expression during the formation of skeletal muscle. Essays Biochem. 20, 77-109.

9. Debus, E. Weber, K. \& Osborn, M. (1983) Monoclonal antibodies to desmin, the muscle specific intermediate filament. EMBO J.2, 2305-2312.

10. De Groot, I.J.M., Lamers, W.H. \& Moorman, A.F.M. (1989) Isamyosin expression patterns during rat heart morphogenesis: an immuno-histochemical study. Anat. Rec. 224, 365-373.

11. De Jong, F. Geerts, W.J.C. Lamers, W.H., Los, J.A. \& Moorman, A.H.M. (1990) Isomyasin expression during formation of the tubular chicken heart: a three-dimensional immunohistochemical analysis. Anat. Rec. 226, 213-227.

12. Gosz, A.A., Antin, P.B., Nachmias, V.T. Holtzer. H. (1984) The relationship between stress fiber-like structures and nascent myotibrils in cultured cardiac imyocytes. J. Cell Bial. 99, 2268-2278.

13. Fischman, D.A. (1986). Myofibrillogenesis and the morphogenesis of skelatall muscle. In: Myology. Basic and Clinical. (Engel, A.G. \& Banker B.Q., Eds.), pp. 530. New York: McGraw-Hill.

14. Frank, E.D., Tuszynski, P. \& Warren, L. (1982) Localization of vimentin and desmin in BHK21/C13 cells and in baby hamster kidney. Exp. Cell Res. 139. $235-247$.

15. Fultan, A.B. \& Isaacs, W.B. (1991) Titin, a huge, elastic sarcomeric protein with a probable role in morphogenesis. BioEssays 13,157-161.

16. Fürst, D.O., Osborn, M. Nave, R. \& Weber, K. (1989) Myogenesis in the mouse embryo: differential onset of expression of myogenic proteins and the involvement of titin in myofibril assembly. J. Cell Biol. 109, 517-527. 
17. Gard. D. Lazarides. E. (1980) The synthesis and distribution of desmin and wimentin during myogenesis in vitro. Cell 19, 263-275.

18. Greaser, M.L., Handel, S.E., Wang. S.-M., Schultz, E., Bulinski, J.C. \& Lessard. J.L. (1989) Assembly of titin, myosin, actin and tropomyosin into myofibrils in cultured chick cardilamyocytes. In: Cellular and molecular brology of muscle development (Stockdale. F. Kedes, L., Eds.). pp. 246-257, New York: Liss, New Series, Vol. 93.

19. Handel, S.E., Wang. S.M., Greaser, M., Schultz, E., Bulinski, J.C. \& Lessard, \.L. (1989) Skeletal muscle myofibrillogenesis as revealed with a monocllonal antibody to titin in combination with detection of the alpha- and gamma isoforms of actin. Dev. Brol. 132, 35-44.

20. Handel, S.E., Greaser, M.L., Schultz, E., Wang, S.-M., Bulinski, J.C., Lin, J.J.-C. \&essard, J.L. (1991) Chicken cardiac myofibrillogenesis studied with antibodies specific for titin and the muscle and nonmuscle isoforms of actin and tropomyosin. Call Tissue Res. 263, 419-430.

21. Holtzer, H., Schultheiss, T., Dillullo, C., Choi, J., Costa, M, Lu, M. \& Holtzer, S. (1990) Autonomous expression of the differentiation programs of cells in the cardiac and skeletal myogenic lineages. Ann. NY Acad. Sci. 599, 158-169.

22. Kimes, B.W. \& Brandt, B.L. (1976) Properties of a clonal muscle cell line from rat heart. Exp. Cell Res. 98, 367-381.

23. Laemmli, U.K. (1970) Cleavage of structural proteins during the assembly of the head bacteriophage T4. Nature 227, 680-685.

24. Lompre, A.-M. Nadal-Ginard, B. \& Mahdavi, V. (1984) Expression of the cardiac ventricular $a^{*}$ and B-Myosin Heavy Chain gemes is developmentally and hormonally regulated. U. Biol. Chem. 259, 6437-6446.

25. Lu. M.H., Dilullo, C., Schultheiss, T., Holtzer, S., Murray, J.M., Choi, J., Fischman, D.A. \& Holtzer, H. (1992) The vinculin / sarcomeric a-actinin / $a$-actin nexus in cultured cardiac myocytes. J. Cell Biol. 117, 1007-1022.

26. Lyons, G., Schiaffino, S., Sassoon, D., Barton, P. \& Buckingham, M. (1990) Developmental regulation of myosin gene expression in mouse cardiac muscle. $J$. Cell Bial. 111, 2427-2436.

27. Maruyama, K. (1994) Connectin, an elastic protein of striated muscle. Biophysical Chemistry 50, 73-85.

28. Masaki, T., Bader, D.M., Reinach, F.C., Shimizu, T. ,Obinata, T., Shafiq, S.A. B. Fischman, D.A. (1982) Monoclonal antibody analysis of myosin heavy chain and the protein isoforms during myogenesils. In: Molecular and cellular control of muscle development. (Pearson, M., Epstein, H., Kaufman, H.S. \& Garrels, J.L.. Eds.). pp. 405-417, Cold Spring Harbor Lab Press.

29. Nag, A.C.. Krehel, W. \& Cheng, M. (1986) Distribution of vimentin and desmin filaments in embryonic cardiac muscile cells in culture. Cytobios 45, 195-209.

30. Osborn, M. \& Weber, K. (1982) Immunofluorescence and immunocytochemical procedure with affinity purified antibodies: tubulin-containing structures. Methods Cell Biol. 24, 97-132.

31. Pieper, F.R., Slobbe, R., Ramaekers, F.C.S., Cuijpers, H.T. \& Bloemendal, H. (1987). Upstream regions of the hamster desmin and vimentin genes regulate expression during in vitro myogenesis. EMBO $4.6,3611-3618$.

32. Quinlan, R.A. \& Franke. W.W. 11982). Heteropolymer of vimentin and desmin in vascular smooth muscle and cultured baby hamster kidnev cells demonstrated by chamical crosslinking. Proc. Natl. Acad. Sci. U.S. A. 79, 3452-3456.

33. Ramaekers, F.C.S. Huijsmans, A., Moesker, O., Kant, A. Jap. P., Herman, C. \& Vooijs. P. (1983). Monoclonal antibodies against keratin filaments, specific for glandular epithellia and their tumours. Use in surgical pathology. Lab. Invest. 49, $353-361$. 
34. Ramaekers, F.C.S., Moesker, O., Huijsmans, A. Schaart, G., Westerhof, G., Wagenaar, Sj.Sc., Herman, C.J. \& Vooijs, G.P. (1985) Intermediate filament proteins in the study of tumor heterogeneity: an in-depth study of tumors of the urinary and respiratory tracts. Ann. NY,Acad. Sci. 455 614-634.

35. Ramaekers, F.C.S., Huijsmans, A., Schaart, G., Moesker, O. Vooijs, G.P. (1987) Tissue distribution of keratin 7 as monitored by a monoclonal antibody. Expl. Cell Res. 170, 235-249.

36. Rudzicka, D.L. \& Schwarz, R.J. (1988) Sequential activation of a actin genes during avian cardiogenesis: vascular smooth muscle $a$-actin gene transcripts mark the onset of cardiomyocyte differentiation. $J$ Cell Blol. 107, 2575-2586.

37. Schaart, G., Viebahn, C. Langmann, W. \& Ramaekers, F.C.S. (1989) Desmin and titin expression in early postimplantation mouse embryos. Development 107. 585.596 .

38. Schaart, G. Pieper, F.R., Kuijpers, H.J.H. Bloemendal, H. \& Ramaekers, F.C.S. (1991) Baby hamster kidney (BHK-21/C13) cells can express striated muscle type proteins. Differentiation 46, 105-115.

39. Schaart, G., Van der Ven, P.F.M. \& Ramaekers, F.C.S. (1993) Characterization of cardiotin, a structural component in the myocard. Eur. J. Cell Biol. 62. 34-48.

40. Skalli, O., Ropraz, P., Trzeciak, A., Benzonana, G., Gillessen, D. \& Gabbiani, G. (1986) A monocional antibody against $a$-smooth muscle actin: a new probe for smooth muscle differentiation. $J$. Cell Biol. 103, 2787-2796.

41. Skalli, O., Gabbiani, G., Babaï, F., Seemaver, T.A. Pizzolato, G. \& Schürch, W. (1988) Intermediate filament proteins and actin isoforms as markers for soft tissue tumor differentiation and origin. II. Rhabdomyosarcomas. Am. $\downarrow$. Pathol. $130,513-531$.

42. Stoker, M.P.G. \& MacPerson, I.A. (1961) Studies on transfection of hamster cells by polyoma virus in vitro. Virology $14,359-370$.

43. Tokuyasu, K.T., Maher, P.A. \& Singer, S.J. 11984$)$ Distributions of vimentin and desmin in developing chick myotubes in vivo. II. Immunotluorescence study $J$. Cell Bial. 96, 1961-1972.

44. Tokuyasu, K.T. \& Maher. P.A. (1987) Immunocytochemical studies of cardiac myofibrillogenesis in early chick embryos. I. Presence of immunofluorescent titin spots in premyofibril stages. $J$. Cell Biol. 105, 2781-2793.

45. Towbin, H., Staehelin, T. \& Gordon, J. (1979) Electrophoretic transfer of proteins from polyacrylamide gels to nitrocellulose sheets: procedure and some applications. Proc. Natl. Acad. Sci. 76, 4350-4353.

46. Traub, P. (1985) Intermediate filaments: A Review. Berlin: Springer Verlag.

47. Trinick, J. (1992) Understanding the functions of titin and nebulin. FEBS Lett. $307,44-48$.

48. Vandekerckhove, J. \& Weber, K. (1978) At least six different actins are expressed in a higher mammal: an analysis based on the amino acid sequence of the amino-terminal tryptic peptide. $\int$ Mol. Biol. 126, 783.802.

49. Vandekerckhove, J. \& Weber, K. (1981) Actin typing on total cellular extracts: a highly sensitive protein-chemical procedure able to distinguish different actins. Eur. J. Biochem. 113, 595-603.

50. Vandekerckhove, J., Bugaisky, G. \& Buckingham, M. (1986) Simultaneous expression of skeletal muscle and heart actin prateins in warious striated muscle tissues and cells. J. Biol. Chem, 261, 121-129.

51. Van der Loop. F.T.L., Schaart, G., Langmann, W. Ramaekers, F.C.S. \& Viebahn, Ch. (1992) Expression and organization of muscle specific proteins during the early developmental stages of the rabbit heart. Anat. Embryol 185, 439-450.

52. Van der Ven. P.F.M., Schaart, G., Jap, P.H.K., Sengers, R.C.A., Stadhouders, A.M. \& Ramaekers, F.C.S. (1992) Differentiation of human skeletal muscle cells 
in culture: maturation as indicated by titin and desmin striation. Cell Tissue Res. $270,189-198$.

53. Van der Ven, P.F.M., Schaart, G., Croes, H.J.S., Jap. P.H.K. Ginsel, L.A. \& Ramaekers. F.C.S. (1993) Titin aggregates associated with intermediate filaments align along stress fiber-fike stuctures during human skeletal muscle cell differentiation. d. Cell Sci. 106, 749-759.

54. Viebahn, Ch., Lane, E.B. \& Ramaekers. F.C.S. (1988) Keratin and vimentin expression in carly organogenesis in the rabbit embryo. Celf Tissue Res. 253, $553-562$.

55. Vitadello, M. Matteoli, M. \& Gorza, L. (1990) Neurafilament proteins are coexpressed with desmin in heart conduction system myocytes. J. Cell Sci. 97, $11 \times 21$.

56. Wang, S.M. \& Greaser, M.L. (1985) Immunocytochemical studies using a monoclonal antibody to bovine cardiac titin on intact and extracted myofibrils. $J$. Muscle Res. Cell Motil. 6, 293-312.

57. Whalan, R.G., Sell, S.M., Butler-Brown, G.S., Schwartz, K., Bouweret, P. \& Pinset-Härström, 1. (1981) Three myosin heavy chain isozymes appear sequentially in rat muscle development. Nature 292, 805-809.

58. Woodcock-Mitchell, J., Mitchell, J.J., Low R.B., Kieny, M., Sengel, P.. Rubbia, L.. Skalli, O., Jackson, B. Gabbiani, G. (1988) a-Smooth muscle actin is transiently expressed in embryonic rat cardiac and skeletal muscles. Differentiation $39,161-166$.

59. Yaffe, D. \& Saxel, 0. (1977) Seriall passaging and differentiation of myogenic cells isolated from dystrophic mouse muscle. Nature 270, 725-727. 


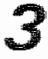

\section{Integration of titin into the sarcomeres of cultured differentiating human skeletal muscle cells.}

Frank T.L. van der Loop, Peter F.M. van der Ven, Dieter O. Fürst, Mathias Gautel, Guillaume J.J.M. van Eys and Frans C.S. Ramaekers.

European Journal of Cell Biology: In press.

Titin is amongst the first sarcomeric proteins to be detected in the process of myofibrillogenesis of striated muscle. During embryogenesis this high molecular weight protein is initially observed in a punctate staining pattern in immunohistochemical studies, while during maturation titin organizes into a cross-striated pattern. The dynamic process of titin assembly up to its integration into the sarcomeres of cultured human skeletal muscle cells, has been studied in subsequent stages of differentiation with antibodies to four welldefined titin epitopes. Since in maturated muscle cells these epitopes are clearly distinguishable on the extended titin molecule we wondered how these epitopes re-organize during myofibrillogenesis, and whether such a reorganization would reveal important clues about its supramolecular organization during development. immunofluorescence staining of postmitotic mononuclear myoblasts indicate that the investigated epitopes of the titin molecule are displayed in a punctate pattern with neighbouring, but clearly separate spots in the cytoplasm of the cells. During elongation and fusion of the cells, these titin spots associate with stress fiber-like structures to finally reach their position at either the Z-line, the A-I junction or the A-band. We propose that during this transition the large titin molecule is unfolded, with the amino-terminus of the molecule migrating in the direction of the $Z$-line and the carboxy-terminus moving towards the M-line. $\| n$ maturated, fused myotubes the final cross-striated patterns of all investigated titin epitopes are observed. While this process of unfolding of the titin molecule progresses, other compounds of the $Z$-line and the $A$-band migrate to their specific positions in the nascent sarcomere. A-band components, such as 
sarcomeric myosin and Cmprotein, are also observed as dot-like aggregates during inital stages of muscle cell differentiation, and organize into a crossstriated pattern in the sarcomere virtually simultaneously with titin. The Z line associated component desmin organizes into a cross-striated pattern at a later stage.

\section{Introduction}

Titin is a high molecular weight ( $M, 3000 \mathrm{kDa})$ sarcomeric protein. Single molecules span the distance from $Z$ - to $M$-line in the sarcomere (over $1 \mu \mathrm{m}$ ), with the carboxy-terminal end of titin at the $M$-band $[6,7,18$, reviews: 10,19$]$. Several authors have reported that titin is amongst the first sarcomeric proteins to be detected during myofibrillogenesis [28 (and references therein)]. The protein has been suggested to play an important role in the supramolecular organization of other myofibrillar proteins $[8,22,25,26$; review 5]. At the onset of the formation of myofibrils in cardiac and skeletal muscle differentiation in vivo, titin is first expressed in a punctate pattern, while during maturation the titin aggregates organize into a cross-striated staining pattern $[8,25,28,33]$. Also differentiating muscle cells in culture display a reorganization of titin from randomly located titin dots into a striated pattern during differentiation. In earlier communications a leading role of titin in the process of myogenesis has been suggested $[22,23,28,29,30,31]$.

Immediately subsequent to synthesis the titin molecules are linked to the cytoskeleton $[3,15]$, probably to desmin intermediate filaments (IF) [31]. One of the functions of the desmin IF may concern the guidance of perinuclearly synthesized titin molecules to stress fiber-like structures (SFLS), since at a later stage of maturation the IF-associated titin aggregates were found in association with SFLS, located beneath the sarcolemma $[30,31]$. The association of titin with SFLS was suggested to be crucial for its reorganization and for the subsequent assembly into sarcomeres [31].

The size and the longitudinal intrasarcomeric organization allow the visualization of the fate of distinct portions of the titin polypeptide by using monoclonal antibodies specific for different epitopes that cover the whole molecule. Such antibodies offer opportunities to study the temporal and spatial distribution of the different epitopes during myogenesis, and to provide insight into the intrasarcomeric reorganization of titin. For this purpose cultured human skeletal muscle cells were used, which successfully have been used as an excellent model system to study molecular processes involved in sarcomere formation $[30,31]$. Another advantage of this system is that it allows a relatively high resolution analysis at the light microscopical llevel. The present in vitro study has focussed on the spatial reorganization of the titin molecule during muscle cell differentiation in relation to several other important sarcomeric proteins. 


\section{Materials and methods}

\section{Muscle cell cultures.}

Human satellite cells were isolated and cultured as described before $[2,30,31]$. Briefly, cells were enzymatically isolated from normal adult skeletal muscle biopsies using trypsin and collagenase. The cells were plated in $35 \mathrm{~mm}$ culture dishes (Costar, Cambridge, MA, USA) in a high nutrition culture medium supplemented with $20 \%$ fetal calf serum (FCS; HyClone Laboratories Inc. Logan, UT, USA) and $2 \%$ chicken embryo extract (CEE; Flow Laboratories, Irvine, UK). Cells were trypsinized and stored in liquid nitrogen in culture medium containing $10 \%$ DMSO. For the experiments described here, these cells were quickly thawed, resuspended in FCS/CEE medium, seeded in culture dishes or on glass cover slips and, after a medium switch, grown to near confluency in culture medium containing $4 \%$ Ultroser G (Gibco BRL, Paisley, UK). Differentiation of the cells was induced by changing the culture medium to a low-nutrition medium containing $0.4 \%$ Ultroser $G$.

\section{Antibodies}

The following antibodies were used:

1) 9D10, a mouse monoclonal antibody of the IgM-subclass to titin. This antibody recognizes an epitope in the I-band at the A-l junction in skeletal and cardiac muscle $[13,32]$.

2) T12, a mouse monoclonal titin antibody of the lgG1-subclass which reacts with an epitope in the I-band close to the Z-line [6].

3) T30, a mouse monoclonal titin antibody of the IgG1-subclass which reacts with certain repetitive epitopes in the A-band. T30 detects 5 of the $7 \mathrm{C}$ stripes, that coincide with binding places for myosin associated proteins, i.e. the $\mathrm{C}$-protein and the $\mathrm{H}$-protein [7].

4) T31, a mouse monoclonal titin antibody of the $\operatorname{lgG} 1$-subclass which reacts with repetitive sequences of the A-band. T31 detects both P-stripes that coincide with the binding places of $\mathrm{H}$-protein [7].

The positions of all these titin antibodies are shown in a schematic drawing (Fig. 3.1).

5) pDes, a polyclonal rabbit antiserum raised against chicken gizzard desmin [20], available from Euro-Diagnostica BV (Apeldoorn. The Netherlands).

6) MF2O, a mouse monoclonal antibody of the IgG2a-subclass recognizing all forms of sarcomeric myosin heavy chain [1].

7) $\mathrm{C} 1 \mathrm{C} 2$, a rat polyclonal antibody against cardiac C-protein, an isoform of myosin binding protein $C$ (MyoBP.C) that is located in the A-band of mature sarcomeres [12].

To detect actin in stress fibers rhodamine-phalloidin (Molecular Probes Inc., Eugene, OR, USA) was used.

The monoclonal antibodies $9 D 10$ and MF2O were abtained from the Developmeratal Studies Hybridoma Bank, maintained by the department of Pharmacology and Molecular Sciences, Jahns Hopkins University Schoal of Medicine, Baltimare MD 21205. USA and the Department of Biology, University of lowa, lowa City IA, USA under contract NOH-HD-2-3714. 
Indirect immunofluorescence assays.

Muscle cells, cultured in $35 \mathrm{~mm}$ culture dishes or on glass cover slips, were finsed three times with phosphate buffered saline (PBS; $\mathrm{pH} 7.4$ ), and fixed in methanol/acetone $(1: 1)$ at $-20^{\circ} \mathrm{C}$ for 1 minute. Fixed cells were stored at $-20^{\circ} \mathrm{C}$. When used for immunocytochemical staining assays, the cells were thawed and rinsed briefly with PBS/0.05\% Tween-20 (PBST). Then cells were incubated with the primary antibody (30 min, room temperature), and after extensive washing with PBST for 30 minutes, incubated with a fluorescein isothiocyanate (FITC)- or Texas Red-conjugated subclass-specific secondary antibody, diluted in PBST 130 min, room temperaturel, and washed again for 30 min (PBST). Both incubations were repeated for double label immunofluorescence assays. After washing in PBST, cells were mounted in Mowiol (Hoechst. Frankfurt, Germany) and examined using a Zeiss Axiophot microscope equipped with epi-illumination optics. Because T12, T30 and T31 are of the IgG1-subclass, the titin staining patterns of these reagents were compared to the intracellular distribution of the epitope detected by 9D10, which is of the IgM-subclass.

\section{Confocal Scanning Laser Microscopy.}

Immunostained cells were also studied with a Bio-Rad MRC-600 confocal scanning laser microscope (CSLM; Bio-Rad Laboratories, Richmond, CA, USA), equipped with a Crypton/Argon mixed gas laser (lon Laser Technology, Salt Lake City, UT, USA) with two separate wave lengths for the excitation of FITC (488 $\mathrm{nm})$ and Texas Red (586 nm), mounted on a Zeiss Axiophot microscope. Image processing was performed to obtain optimal contrast and to obtain information on signal colocalization. Videoprints were made using a Mitsubishi videoprinter.

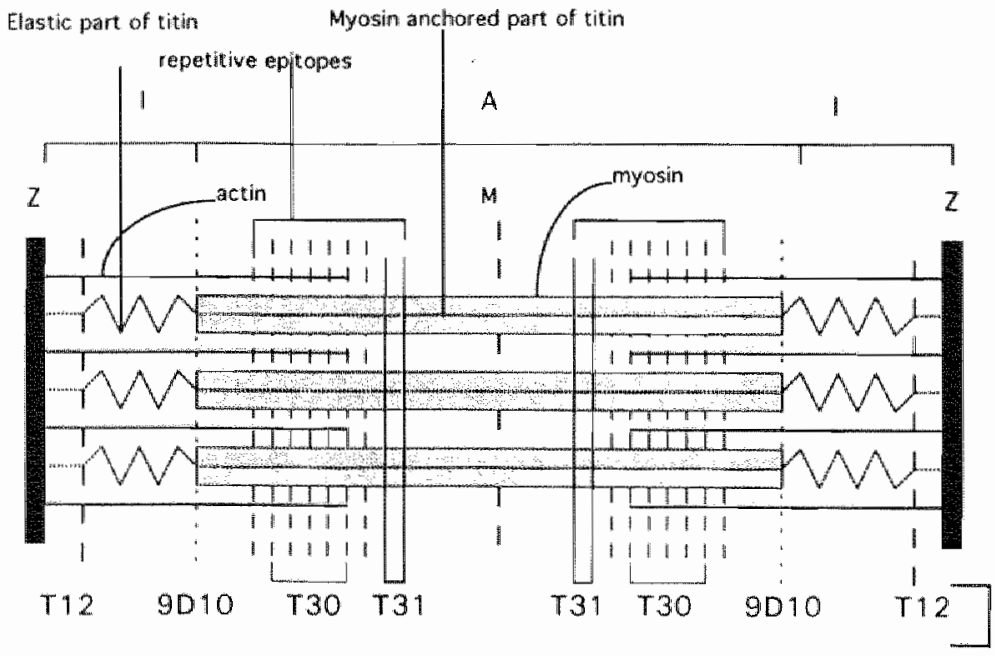

Epitopes

Fig. 3.1: Schematic representation of the mature sarcomere, indicating the position of the titin epitopes used in this study. 


\section{Results}

Myogenesis in cultured, differentiating human skeletal muscle cells.

Cultured human skeletal myoblasts can be induced to differentiate into myotubes $[30,31]$ using a medium switch. These satellite cells or myoblasts demonstrate a spindle shaped to polygonal morphology during their proliferative stages. After a change to a low-nutrition culture medium, the single cells start to differentiate, resulting in postmitotic mononuclear myoblasts (PMM), single cells that have lost their proliferative capacity. Subsequently immature myotubes (IM), elongated single cells that are about to fuse or have fused to form di-, tri- or multinucleated myo-syncytia, form. These progress into maturated myotubes (MM). multinucleated cells containing sarcomeric structures.

\section{Mitotic and Postmitotic Mononuclear Myoblasts.}

Titin, myosin and C-protein were absent in mitotic myoblasts, while desmin was organized in a random network of filaments.

In postmitotic mononuclear myoblasts all four titin epitopes were found as separate aggregates. Double label assays, using two distinct titin antibodies, revealed that these PMM always displayed approximately equal numbers of signals derived from these epitopes. Only sporadic colocalization of different titin epitopes was seen in PMM. T12 (Fig. 3.2a), T30 and T31 fluorescent signals were generally found in close proximity to the nucleus, while the 9D10 signals were normally revealed at a larger distance from the nucleus (Fig. 3.2a). Desmin was still organized in filaments at this stage. In the majority of cells randomly localized myosin aggregates (Fig. 3.2e) were observed. C-protein was also found in a punctate staining pattern. A small number of C-protein aggregates was found in close proximity to the nucleus (not shown), but the number of C-protein signals was low as compared to the number of titin spots in these cells. No colocalization of titin signals was found with myosin (Fig. 3.2e) or C-protein.

\section{Elongated Cells and Immature Myotubes.}

In elongated cells and immature myotubes, titin aggregates were partially organized along stress fiber-like structures, as detected by rhodaminephalloidine. Occasionally the density of titin aggregates allong SFLS was very high and as a result the titin staining patterns seemed filamentous. This SFLS associated pattern of titin gradually changed into a cross-striated appearance, as observed in mature myotubes. There was no colocalization of the different titin epitope signals. Although in most cells all the titin epitopes were preferentially found located along SFLS, the signals of 9D10 were occasionally detected scattered in the cytoplasm, whereas 9D10 organization also was found to be ahead of the other titin epitopes in some cells. In immature multinucleated myofibrils the T12 epitope was generally located further away from the nucleus than the A-\| junction epitope (9D10) which was located in closer proximity to the nuclei (Fig. 3.2b). The T30 epitope on the other hand was displayed closer to the nucleus than the 9D10 epitope. In addition to these staining patterns, the 

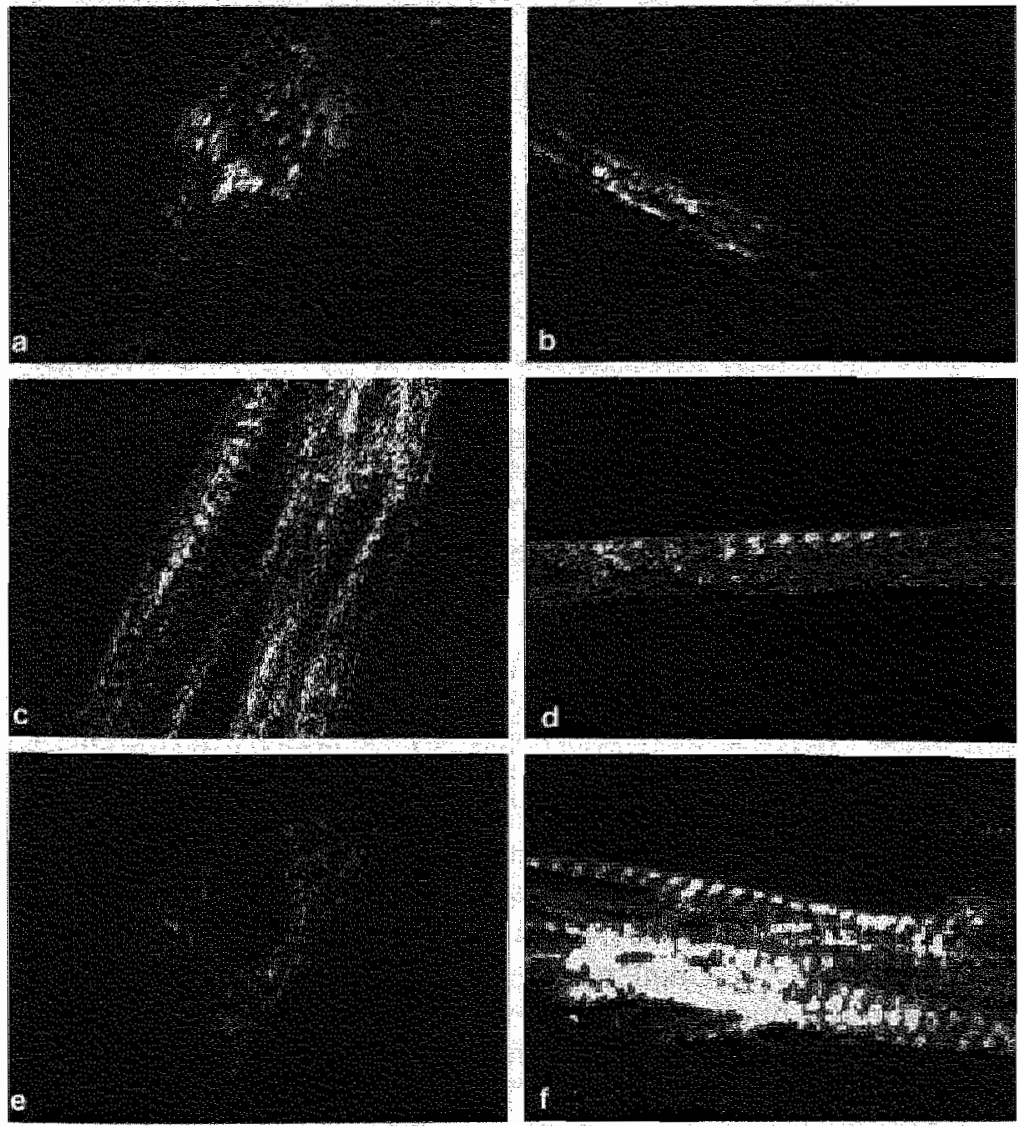

Fig. 3.2: Double immunostained differentiating human skeletal muscle ciells in culture, analysed by confocal scanning laser microscopy. Figures (ainc) show the reorganization of the titin epitopes
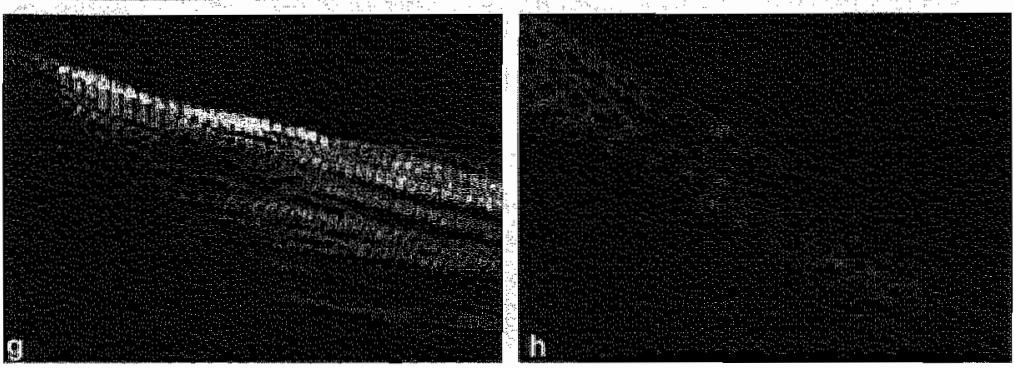

T12 (green) and 9010 (red) in postmitatic mononuclear myoblasts (a). elongated cells (b), and mature myotubes $(c)$. The alternating cross-striations of titin epitopes T30 (red) and 9D10 (green) in mature myotubes are displayed in (d). There is no colocalization of titin epitope $\$ 42$ (green) and striated muscle specific myosin (red) in postmitotic mononuclear myoblasts $(e)$ or cross-striated sarcomeres (f), but there is a signal overlap of $T 30$ (red) and myosin (green), resulting in a yellow cross-striated staining pattern, in mature sarcomeres (g). T30 (red) and C-protein (green) do not colocalize in highly organized sarcomeres of cultured human skeletal muscle cells (h). 
first cross-striated patterns were found in these maturating myofibrils. Desmin was still organized in IF that appeared parallel to arrays of titin dots, organized along SFLS (not shown). In elongated cells, the C-protein was still found in dotlike aggregates. After cell fusion a stress fiber-like staining pattern was observed for C-protein, whereas myosin was still present in scattered aggregates.

\section{Mature Myotubes}

In maturating and mature myotubes, all titin epitopes were displayed in a crossstriated pattern (Fig. $3.2 \mathrm{c}$, d), although the reorganization process of the T31 epitope was slow as compared to the other three epitopes. Myosin was now organized in a cross-striated fashion. The Z-line associated marker desmin did not yet show a striated pattern at this stage, but was still occuring as filaments. C-protein was organized in a cross-striated pattern with very delicate striations. Because the T12 epitope is located outside the myosin-binding region of titin, separate staining patterns were found for T12/MF20 double stained myotubes (Fig. 3.2f). On the other hand, double staining of myotubes with $T 30$ and MF20 indicated a colocalization of these two antigens (Fig. $3.2 \mathrm{~g}$ ), in accordance with the fact that the T30 epitope is located within the myosin binding region of titin. The re-organization of C-protein was completed slightly before discrete T30 cross-striations were present. Although the T30-epitope and C-protein are located closely together in the sarcomere, no signal overlap of these two components was found in high magnification CSLM-analysis (Fig. 3.2h).

\section{Discussion}

Titin is one of the first markers in the differentiation of striated muscle cells, both in vivo $[8,22,28]$ and in witro $[29,30,31]$. It is suggested to play a role in the supramolecular organization of other sarcomeric proteins. Although the order of protein expression and organization in myofibrillogenesis varies between different species and cell lines, the overall pattern of titin expression is similar. Titin molecules are perinuclearly synthesized and appear as randomly localized dots in postmitotic mononuclear myoblasts. When the cells become elongated or start to fuse, these dots organize along SFLS, described to function as transient assembly sites for nascent myofibrils [4]. In mature myotubes, a striated staining pattern of specific titin epitopes is found.

\section{Titin reorganization and sarcomere formation.}

Differentiated myotubes display discrete cross-striations of the 4 epitopes investigated. Double staining experiments of these titin epitopes with striated muscle specific myosin heavy chain, revealed that the process of association of titin and the thick myosin filaments in this in vitro-model is representative for the in wivo-situation: no colocalization was seen with the $Z$-line epitope of titin, whereas the A-band titin epitopes and myosin are colocalized. Double staining of 


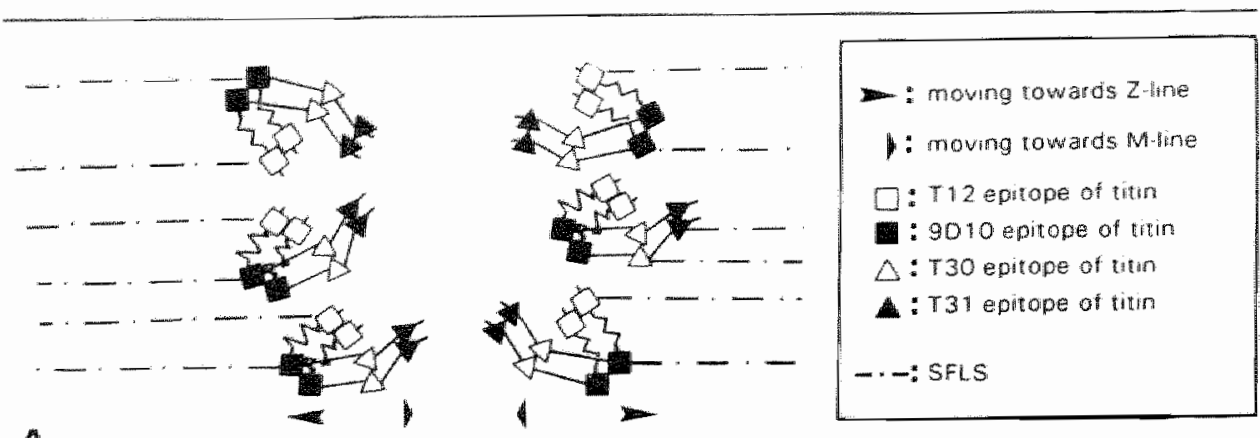

A
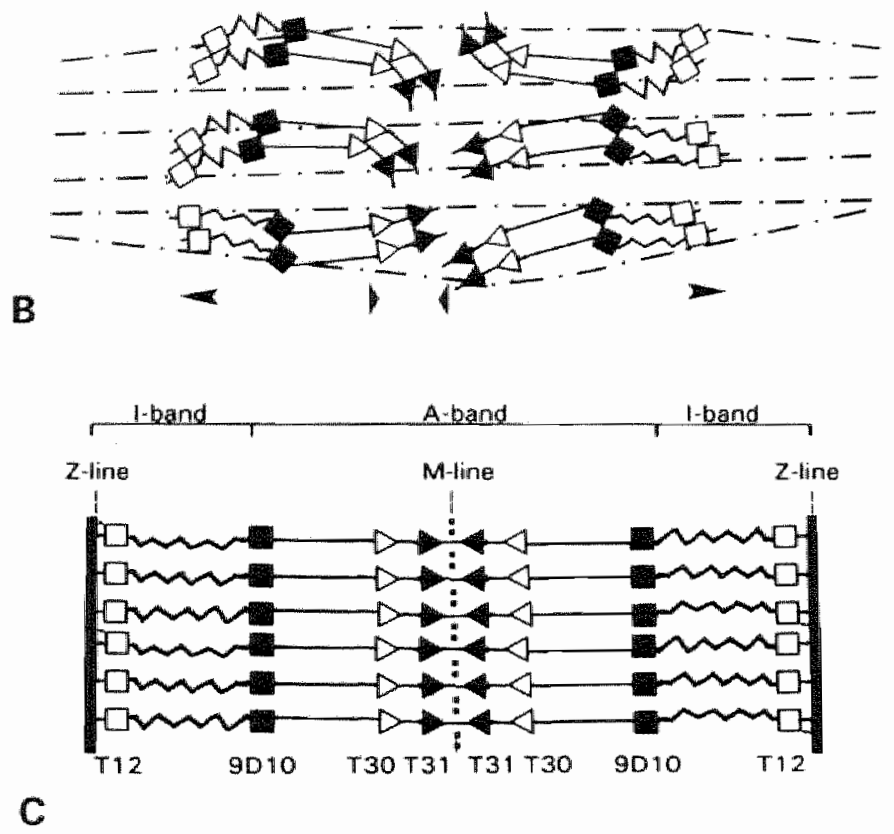

Fig. 3.3: Schernatic representation of the process of titin reorganization and incorporation into the sarcomere. Clusters of titin molecules in the postinitotic mononuclear myoblasts (a) start to unfold (guided by SFLS) in the elongating and fusing cells (b), resulting in a cross-striated pattern in highly arganized sarcomeres (c).

the T30 epitope and the (cardiac) isoform of C-protein, present in small amounts as indicated by delicate lines, revealed that both epitopes are located closely together, but do not colocalize. All four titin epitopes investigated were detected 
in virtually equal numbers of aggregates in the subsequent stages of muscle cell differentiation. The close proximity of the different titin epitopes, which occur as aggregates, in PMM suggests that these molecules have a folded appearance in these cells. The position of the epitopes in the cells did not reflect the order in which they are positioned along the molecule. Also, the initial distance from the nucleus was not correlated with their final position. For instance, epitope 9D10, located in the middle-region of the titin molecule, was found at larger distances from the nucleus than the more peripheral epitope T12 or the more centrally located epitopes T30 and T31. The clusters of epitopes are observed as clearly separate dots. This indicates a certain degree of organization of the newly synthesized titin molecules, i.e. an organization comprising a number of staggered titin molecules (Fig. 3.3a). Parallel arrays of a number of molecules will present particular epitopes as one dot, that can be seen by immunofluorescence.

As cells elongate, titin molecules appear to attach to SFLS (Fig. 3.3b), possibly guided by desmin IF $[30,31]$. Upon binding to SFLS, the localization of titin epitopes changes from a random distribution into periodic arrays. The association of the titin aggregates to SFLS and the movement along these fibers may be mediated by the interaction with specific molecules, possibly actin [14]. Rhee and co-workers [21] propose a pre-myofibril model with key roles for nonmuscle myosin Ilb, titin and zeugmatin. In this model actin filaments are involved in the elongation of sarcomeric structures.

During sarcomere formation folded titin unfolds into linear molecules, presumably by moving the carboxy- and amino terminals of the molecules in opposite directions along the SFLS. The almost simultaneous arrival of the four epitopes of the titin molecule at their final destination in the mature myotubes (Fig. $3.3 \mathrm{c}$ ) indicates that once the stretching of the titin bundles has started, this process quickly proceeds to its final stage. There was a small time difference in the integration of the two titin epitopes into the A-band: the T30 epitope is alleady cross-striated at the time point when the T31 epitope is not organized yet. The T30 epitope is associated with myosin and C-protein, two components that are alleady organized in a cross-striated fashion at this stage $[9,17]$. This indicates that the association of titin with myosin and $\mathrm{C}$-protein occurs in an earlier developmental stage than the association with $\mathrm{H}$-protein or the proteins of the M-line, like myomesin and M-protein. Future studies will have to reveal a possible role of $\mathrm{H}$-protein or of the $\mathrm{M}$-line proteins in the final stage of $\mathrm{T} 31$ organization.

A relation has been suggested between the state of phosphorylation of certain sites of the titin molecule and its structural organization $[11,24]$. Folding of titin molecules may be functional in avoiding premature association of titin with other sarcomeric proteins. Our observation that titin dots only rarely colocalize with dots of the A-band components myosin and (cardiac) C-protein in the early stages of myogenesis supports this hypothesis. The unfolding of titin molecules might initiate or regulate the interactions between titin and A-band or M-line components. Therefore, unfolding of the titin molecules may be essential before 
this protein can start to function as a ruler protein, determining the length and the position of the myosin filaments [34; review: 27$]$. In this way titin may orchestrate the supramolecular assembly of myotubes.

Previous studies showed that 1 -band epitopes are the first to take their position in the formation of sarcomeres, followed by titin association with a-actinin $[14,26]$. The observation that Z-line titin epitopes reveal a periodic staining pattern in earlier stages of in vivo development as compared to M-line epitopes, is also supportive of an unfolding process of titin during myofibrillogenesis [8]. The question remains whether there exists a relationship between the unfolding of titin molecules and the stage of organization of the Z-line, which can be monitored with antibodies to a-actinin and desmin. Komiyama and co-workers [16] reported that titin (and also myosin) cross-striations were formed some time after $a^{-a c t i n i n}$ striations were observed in preformed 1-Z-I-like structures in cultured chicken cardiac myocytes. Our study showed that desmin is still organized in filaments up to the stage where titin is fully unfolded. We have earlier shown that fully differentiated myotubes also displayed desmin and $\alpha$ actinin cross-striation [30,31]. However, since the experiments described have focussed on titin organization little attention was paid to the last differentiation stages. Therefore, the unfolding of titin does not seem to be initiated by a fully completed Z-line organization, although anchoring of titin to the $\mathbf{Z}$-line component $a$-actinin seems essential [16].

In summary, the integration process of titin into sarcomeres appears to be related to the presence and organization of certain other sarcomeric components. Anchoring of titin to $\alpha$-actinin in the $Z$-line is supposed to be essential for the integration process of titin in early stages of muscle differentiation $[8,16,31]$, but the underlying study shows that also the organization of the A-band components myosin and C-protein should be considered important for the proper integration of titin into the sarcomere during myofibrillogenesis.

Acknowledgement:

The authors would like to thank J...Ausma for providing the schematic drawing in figure 3.1.

\section{References}

1. Bader, D. T. Masaki, D.A. Fischman: Immunohistochemical analysis of myosin heavy chain during avian myogenesis in vivo and in vitro. J. Cell Biol. 95, 763$770(1982)$.

2. Benders, A.A.G.M., T.H.M.S.M. van Kuppeveldt, A. Oosterhof, J.H. Veerkamp: The biochemical and structural maturation of human skeletal muscle cells in culture: the effect of the serum substitute Ultroser G. Exp. Cell Res. 195, 284294 (1991).

3. Colley, N.J., K.T. Tokuyasu, S.J. Singer: The early expression of myofibrillar proteins in round postmitotic myoblasts of embryonic skeletal muscle. J. Cell Sci. 
$95,11-22(1990)$.

4. Dlugosz, A.A., P.B. Antin, V.T. Nachmias. H. Holtzer: The relationship between stress fiber-like structures and nascent myofibrils in cultured cardiac myocytes. J. Cell Biol. 99, 2268-2278(1984).

5. Fulton, A.B., W.B. Isaacs: Titin, a huge, elastic sarcomeric protein with a probable role in morphogenesis. BioEssays 13, 157-161 (199\#\%.

6. Fürst, D.O., M. Osborn, R. Nave, K. Weber: The organization of titin flaments in the half-sarcomere revealed by monoclonal antibodies in immunoelectron microscopy: a map of ten nonrepetative epitopes starting at the $Z$-line extends close to the $M$ line. J. Cell Biol. 106,1563 m1572119881.

7. Fürst, D.O., R. Nave, M. Osborn, K. Weber: Repetitive titin epitopes with a 42 nm spacing coincide in relative position with known $A$ band striations also identified by major myosin-associated proteins. An immunoelectron-microscopical study on myofibrils. J. Cell Sci. $94,119-125$ (1989).

8. Fürst, D.O., M. Osborn, K. Weber: Myogenesis in the mouse embryo: differential onset of expression of myogenic proteins and the involwement of titin in myofibrit assembly. J. Cell Biol. 109, 517-527 (1989).

9. Fürst, D.O., U. Vinkemeier, K. Weber: Mammalian skeletal muscle C-protein: purification from bovine muscle, binding to titin and the characterization of a fulllength human cDNA. J. Cell Sci. 102, 769-778 (1992).

10. Fürst, D.O. "M. Gautel: The anatomy of a molecular giant: How the sarcomere cytoskeleton is assembled from immunoglobulin superfamily molecules. J. Mol. Cell. Cardiol. 27, 951-959 (1995).

11. Gautel, M. K. Leonard, S. Labeit: Phosplnorylation of KSP motifs in the Cterminal region of titin in differentiating myoblasts. EMBO $J .12,3827-3834$ (1993).

12. Gautel, M., O. Zuffardi, A. Freiburg, S. Labeit: Phosphorylation switches specific for the cardiac isoform of myosin binding protein-C: a modulator of cardiac contraction? EMBO J. 14, 1952-1960(1995).

13. Greaser, M.L., S.E. Handel, S.M. Wang, E. Schultz, J.C. Bulinski, J.L. Lessard: Assembly of titin, myosin, actin and tropomyosin into myofibrils in cultured chick cardiamyocytes. In: F. Stockdale, L. Kedes (eds.): Cellular and molecular biology of muscle development. UCLA Symposium on molecular and cellular biology. Vol. 93. pp. 246-257. New Series, Liss, New York 1989.

14. Handel, S.E., S.M. Wang, M.L. Greaser, E. Schultz, J.C. Bulinski, J.L. Lessard: Skeletal muscle myofibrillogenesis as revealed with monoclonal antibody to titin in combiunation with detection of alpha and gamma isoforms of actin. Dev. Biol. $132,35-44(1989)$.

15. Isaacs, W.B., I.S. Kim, A. Struve, A.B. Fulton: Biosynthesis of titin in cultured skeletall muscle cells. J. Cell Biol. 109, 2189-2195(1989).

16. Komiyama. M., K. Kouchi, K. Maruyama, Y. Shimada, Y.: Dynamics of actin and assembly of connectin (titin) during myofibrillogenesis in embryonic chick cardiac muscle cells in vitro. Dev. Dynam. 196, 291-299(1993).

17. Koretz, J.F., T.C. Irving, K. Wang: Filamentous aggregates of native titin and binding of C-protein and AMP-deaminase. Arch. Biochem. Biophys. 304. 305$309(1993)$.

18. Labeit, S., M. Gautel, A. Lakey, J. Trinick: Towards a molecular understanding of titin. EMBO J. 11, 1711-1716(1992).

19. Maruyama, K.: Connectin, an elastic protein of striated muscle. Biophys. Chem. 50, 73-85(1994).

20. Ramaekers, F.C.S., O. Moesker, A. Huijsmans, G. Schaart, G. Westerhof, Si.Sc. Wagenaar, C.J. Herman, G.P. Vooijs: Intermediate filament proteins in the study of tumor heterogeneity: an in-depth study of tumors of the urinary and respiratory tracts. Ann. NY Acad. Sci. 455, 614-634(1985). 
21. Rhee, D., J.M. Sanger, J.W. Sanger: The premyofibril: evidence for its role in myobibrillogenesis. Cell Motil. Cytoskel. 28, 1-24 (1994).

22. Schaart, G., C. Viebahn, W. Langmann, F.C.S. Ramaekers: Desmin and titin expression in early postimplantation mouse embryos. Development 107. 585 $596(1989)$.

23. Schaart, G. F.R. Pieper, H.J.H. Kuijpers, H. Bloemendal, F.C.S. Ramaekers: Baby hamster kidney (BHK-21/C13) cells can express striated muscle type proteins. Differentiation 46, 105-115 (1991).

24. Sommerville, L.L.. K. Wang: Sarcomere matrix of striated muscle: in wivo phosphorylation of titin and nebulin in mouse diaphragm muscle. Arch. Biochem. Biophys. 262, $118-129(1988)$.

25. Tokuyasu, K.T. P.A. Maher: Immunocytochemical studies of cardiac myofibrillogenesis in early chick embryos. I. Presencie of immunofluorescent titin spots in premyofibril stages. J. Cell Biol. 105, 2781-2793(1987).

26. Tokuyasu, K.T. P.A. Maher: Immunocytochemical studies of cardiac myofibrillogenesis inearly chick embryos. II. Generation of a-actinin dots within titin spots at the time of the first myofibril formation. J. Cell Biol. 105, 27952801 (1987).

27. Trinick, J.: Titin and nebulin: protein rulers in muscle? Trends Biochem. Sci. 19. 405-409(1994).

28. Van der Loop, F.T.L., G. Schaart, W. Langmann, F.C.S. Ramaekers, C. Viebahn: Expression and organization of muscle specific proteins during the early devellopmental stages of the rabbit heart. Anat. Embryol. 185, 439-450 (1992).

29. Van der Loop. F.T.L., G.J.J.M. van Eys, G. Schaart, F.C.S. Ramaekers: Titin expression as an early indication of heart and skeletal muscle differentiation in vitro. Developmental re-organization in relation to cytoskeletal constituents. J. Muscle Res. Cell Motil. In press (1995).

30. Van der Ven, P.F.M., G. Schaart, P.H.K. Jap, R.C.A. Sengers, A.M. Stadhouders, F.C.S. Ramaekers: Differentiation of human skeletal muscle cells in culture: maturation as indicated by titin and desmin striation. Cell Tissue Res. 270, $189.198(1992)$.

31. Van der Ven, P.F.M. G. Schaart, H.J.E. Croes, P.H.K. Jap, L.A. Ginsel, F.C.S Ramaekers: Titin aggregates associated with intermediate filaments align along stress fiber-like structures during human skeletal muscle differentiation. J. Cell Sci. 106, 749-759 (1993).

32. Wang. S.M. M.L. Greaser: Immunocytochemical studies using a monoclonal antibody to bovine cardiac titin on intact and extracted myofibrils. J. Muscle Res. Cell Motil. 6, 293-312(1985),

33. Wang, S.M., M. Greaser, E. Schultz, J.C. Bulinski, J.J.C. Lin, J.L. Lessard: Studies on cardiac myofibrillogenesis with antibodies to titin, actin, tropomyosin and myosin. J. Cell Biol. 107, 1075-1083(1988).

34. Whiting, A., J. Wardalle, J. Trinick: Does titin regulate the llenth of muscle thick filaments. J. Mol. Biol. 205, 263-268(1989). 


\section{Expression and organization of muscle specific proteins during the early developmental stages of the rabbit heart.}

Frank T.L. van der Loop, Gert Schaart, Helma Langmann,

Frans C.S. Ramaekers and Christoph Viebahn.

Anatomy and Embryology (1992) 185: $439-450$.

The expression and intracellular distribution patterns of muscle-specific proteins were studied during rabbit embryo development $(7-13 \mathrm{dpc})$ using monoclonal antibodies against titin, myosin, tropomyosin and actin, as well as the intermediate filament proteins desmin, keratin and vimentin. From our panel, titin appeared to be the first muscle-specific protein to be exclusively expressed in the embryonic rabbit heart. Upon differentiation (myocyte and myotube formation), titin reorganizes from dot-like aggregates into a cross-striated pattern (in 9- to 30-somite embryos) via a transiently filamentous distribution. When the expression and organization of the other muscle proteins was studied in relation to titin, it became apparent that tropomyosin followed upon titin with respect to its exclusive expression in the heart anlagen and its organization into a striated pattern. Myosin and desmin were organized into cross-striated patterns after titin and tropomyosin, but this arrangement had not reached its final form in 13-dpc embryos. Actin, keratin and vimentin were distributed in cytoplasmic filaments in the embryologic stages we investigated. Since the first pulsations are already detected in 3-somite embryos, we conclude that the organization of titin. tropomyosin, myosin and desmin into a striated pattern does not seem to be essential for the initiation of muscle cell contraction in the heart anlagen. Furthermore, this study shows that, in comparison with studies on mouse, chick and rat, the sequence of expression of muscle-specific and intermediate fillament proteins during cardiomyogenesis is species-dependent, and that their expression and organization varies in time in different regions of the developing heart. 


\section{introduction}

Monocional and polyclonal antibodies against muscle-specific proteins have proved to be useful tools in studying the structural organization of functional cell organelles during the early heart development in vertebrates 1 Danto and Fischman 1984: Tokuyasu and Maher 1987a, b; Kuruc and Franke 1988; Schaart et all, 1989). During cardiogenesis the different structural proteins appear at different phases of development and myofibril formation. The organization of most muscle-spectic proteins at the cellular and sarcomeric level changes during the differentiation of these units. As an important high-molecular-weight elastic protein that is restricted to skeletal and cardiac musche cells and does not occur in smooth muscle cells, titin undergoes such organizational changes (Wang et al. 1979; Isaacs and Fulton 1991). Titin, also known as connectin (Maruyama 19861, first appears as dot-like aggregates in skeletal or cardiac myoblasts of mouse and chick (Tokuyashu and Maher 1987a and 1987b. Fürst et al. 1989, Schaart et al. 1989). During further dufferentiation of myoblasts a more filamentous organization is seen, while in differentiated myotubes titin occurs in a cross-striated pattern. During myogenesis, titin is already arranged in a striated fashion before the first periodic arrays of other muscle-specific proteins or intermediate filament proteins (IFP) are seen (Fulton and Isaacs 19911. Monoclonal and polyclonal antibodies against titin may therefore be reagents detecting an early marker in cardiogemesis. They can further indicate the progress of muscie cell differentiation by specific staining patterns. Another commonly used marker protein in myogenesis is desmin "Debus et al. 1983: Hill et al. 1986\%. This IFP is to a large extent specific for all muscle cells lLazarides and Hubbard 1976; Fischman 1986; for exeptions see Molengraft et all. 1986; Franke and Moll 1987). Desmin also shows differences in organization related to the degree of muscle-development: it is organized in filaments in cardiomyoblasts and connected with Z-lines in adult cardiomyocytes (Fischman and Danto 1985). In developmental studies vimentin is commonly expressed in addition to desmin as a second IFP. Myogenic cells may even coexpress three types of IFP (van Muijen et al. 1987; Kuruc and Franke 1988), the third type being keratin. Keratins, apart from lamins the first cytoplasmic IFP expressed in early embryogenesis. Jackson et al. 19811, are normally found in epithelial cells that are still multipotential in nature, and present in the early embryological phases (Traub 1985). Myosin and actin contribute to contractility and are amongst the most studied proteins in skeletal and cardiac muscle cell differentiation (Sassoon et al. 1988; Lyons et al. 1990a,b; de Jong et al. 1990; Lyons et al. 1991). Closely associated with the actin filaments in cross-striated cells is tropomyosin, a protein that is involved in actin filament formation (Lemanski 1979 ) as a stabilizing factor in the myosin-actin system (Trombitas et al. 1990).

Embryonic development of the rabbit heart differs from that of rodents in that two distinct heart tubes develop on either side of the germinal disc which will later fuse medially (Seidel 1960). This divergent development of the heart in the 
rabbit gave rise to questions about the onset, expression and organization of the muscle-specific constituents and the IFP. The first question was whether detection of the cardiogenic cells was possible by means of specific antibodies before morphologically distinguishable cardiogenic plates were present. The main query, however was which of the muscle-specific proteins described above played a part in heart development, at what stage and how these proteins are organized during embryonic cardiogenesis in the rabbit. The role of titin, an early-expressed muscle-specific protein to be detected in the developing mouse heart (Schaart et al. 1989) was examined, in addition to the expression of myosin, tropomyosin and actin, the proteins that are part of the contractile sarcomeres ILemanski 1979; Sassoon et al. 1988; Lyons et al. 1990bl. We also investigated the IFP desmin, keratin and vimentin because of their role in embrvonic cardiogenesis in other vertebrates (Jackson et a:. 1981; Franke et al. 1982; Danto and Fischman 1984). The presence and the organization of muscle. specific proteins and IFP in the early phases of cardiogenesis of the early rabbit embryo was examined and compared to data of other vertebrates.

\section{Materials and Methods}

Tissue and embryo preparation for immunofluorescence assays.

Cardiac, skeletal and smooth muscle samples were obtained from adult New Zealand White rabbits. Tissues where washed in cold phosphate-buffered saline (PBS: $137 \mathrm{mM} \mathrm{NaCl}$ (Merck, Darmstadt, FRG), $13 \mathrm{mM} \mathrm{Na} \mathrm{HPO}_{4} .2 \mathrm{H}_{2} \mathrm{O}$ (Merck,

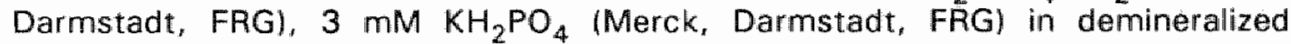
water, $\mathrm{pH} 7.4$ ) to remove blood and then quilckly frozen in liquid nitrogen. Sections were obtailned after embedding the frozen tissue in OCT (Tissue Tec, Miles, Naperville, USA; 10.24\% Polyvinyl Alcohol, 4.26\% Polyethylene Glycol, $85.5 \%$ Nonreactive Ingredientsj. Cryosections $5 \mu \mathrm{m}$ thick were taken up on clean glass slides and air dried before use or storage at $-20^{\circ} \mathrm{C}$.

Rabbit embryos were dissected from uteri at 7-13 days post conceptionem (dpc) under Nembutal anaesthesia (Pentobarbital; $90 \mathrm{mg} / \mathrm{kg}^{*}$ intravenously). After embedding the embryos in gelatine capsules (Balters Union. Liechtenstein) filled with OCT, they were quickly frozen in liquid nitrogen llower half of the capsule first). These encapsuled embryas could than be oriented for the cutting of $5-\mu \mathrm{m}$ thick cryosections, which were taken up on clean glass slides and air dried before use or storage at $-80^{\circ} \mathrm{C}$.

\section{Indirect immunofluorescence assays.}

The $5 \mu \mu m$-thick sections of the adult rabbit tissues were air dried before use, and treated with $0.5 \%$ Triton $\times 100$ (BDH Chemicals Ltd, Poole, UK! in PBS for 5 mir at room temperature (Schaart et al. 1991), followed by washing in PBS. The sections were incubated with the primary, specific antibodies /described in the next paragraphl for $30 \mathrm{~min}$, washed three times in PBS $110 \mathrm{~min}$ each) followed by a $30 \mathrm{~min}$ incubation with the secondary, fluorescein isothiocvanate(FITC). 
conjugated mouse Ig-subclass specific antibody (Nordic Immunochemicals, Tilburg, the Netherlands). The sections were washed in PBS, with three washing steps of 10 min each. Sections were mounted in Fluorostab (Euro-Diagnostica BV, Apeldoorn, the Netherlands) and examined using a Zeiss microscope equipped with epifluorescence illumination optics.

The sections of the embryos were air dried and fixed with methanol (Merck, Darmstadt, FRG) at $-20^{\circ} \mathrm{C}$ for $6 \mathrm{~min}$, followed by an acetone (Merck, Darmstadt, FRG) fixation at $-20^{\circ} \mathrm{C}$ for $0.5 \mathrm{~min}$. After air drying for $15 \mathrm{~min}$ and a PBS-wash for $5 \mathrm{~min}$, the sections were immunostained using either the mono- or the double-label procedure. Both procedures started with a 30 min incubation with the specific monoclonal antibody, followed by a PBS-wash (three times; 5 min each), a $30 \mathrm{~min}$ incubation step with a FITC-, tetramethylrhodamine isothiocyanate(TRITC)- or Texas red(TXRd)-conjugated mouse Ig-specific antibody (Nordic Immunochemicals, Tilburg, the Netherlands or Southern Biotechnology Associates Inc., Birmingham, Alabama, USA) and again rinsing in PBS with three washing steps of $5 \mathrm{~min}$. In the double-label procedure this immunostaining steps were repeated with a second monoclonal antibody of a different lg-subclass. After the mono- or double-labeling procedure the sections were placed in distilled water for $5 \mathrm{~min}$, followed by post-fixation in methanol for 5 min. The sections were air dried and mounted in Mowiol (Hoechst, Frankfurt, FRG; Osborn and Weber 1982). Slides were examined using a Zeiss Universal Microscope equipped with epi-illumination optics.

\section{Antibodies.}

The following antibodies were used in this study (see Table 4.1):

1. A mouse monoclonal antibody 9D10 to titin, reacting with an epitope at the A-I junction in striated and cardiac muscle (Wang et al. 1985; Greaser et al. 1989; Handel et al. 1989).

2. A mouse monoclonal antibody MF20 to striated muscle myosin, reacting with all sarcomere myosin (Bader et al. 1982; Masaki et al. 1982).

3. A mouse monoclonal antibody $\mathrm{CH} 1$ to muscle tropomyosin, labeling both striated (skeletal and cardiac) and smooth muscle cells (Lin et al. 1985).

4. The mouse monoclonal antibody $\mathrm{Sr}-1$, recognizing striated muscle $a$-actin (Skalli et al. 1988), which was a kind gift of Dr. G. Gabbiani (Geneva, Switserland).

5. A mouse monoclonal antibody DE-Fi-11 to desmin (DAKO-patts, Glostrup, Denmark), labeling both striated (skeletal and cardiac) and smooth muscle cells (Debus et all. 1983).

6. The mouse monoclonal antibody RCK106 recognizing keratin 18 (Ramaekers et al. 1987).

7. The mouse monoclonal antibody CAM 5.2 to keratin 8 (Smedts et al. 1990).

8. A mouse monoclonal antibody RV202 against vimentin, described in detail by Ramaekers et al. (1987) and Viebahn et al. (1988). 
The monocional antibodies 9D10, MF2O and CHI were obtained from the Developmental Studies Hybridoma Bank, maintained by the Department of Pharmacology and Molecular Sciences, Johns Hopkins University School of Medicine. Baltimore, Md., USA, and the Departement of Biology, University of lowa, lowa City, IA, USA, under contract NO1-HD-6-2915 from the NICHD.

Preparation and staining of semi-thin plastic sections.

For semi-thin plastic sections embryonic discs were fixed in cold $\left(4^{\circ} \mathrm{C}\right)$ halfstrength Karnovsky's fixative (Karnovsky 1965) in 0.1 M phosphate buffer. After 1 hour the embryonic discs were washed in cold phosphate buffer, and postfixed at $4^{\circ} \mathrm{C}$ for $2 \mathrm{~h}$ using $1 \% \mathrm{OsO}_{4}$ in $0.1 \mathrm{M}$ phosphate buffer. They were dehydrated in a graded series of ethanol and embedded through propylene-oxyde in Durcupan ACM (Fluka Chemie AG, Buchs, FRG). Semi-thin sections (1 $\mu \mathrm{m}$ ) were cut on a Reichert OMU1 ultramicrotome and stained with a mixture of 3 parts $1 \%$ Toluidine blue (Merck, Darmstadt, FRG) in 1\% Borax (Merck, Darmstadt, FRG) and 1 part $1 \%$ Pyronin G (Fluka Chemie AG, Buchs, FRG).

Table 4.1:

Characteristics of monoclonal antisera used in this study and their staining reactions in muscle tissue as tested by the indirect immunfluorescence assay.

\begin{tabular}{|c|c|c|c|c|c|c|c|}
\hline \multirow[t]{2}{*}{ Antibody } & \multirow{2}{*}{$\begin{array}{l}\text { Antigen } \\
\text { recognized }\end{array}$} & \multirow{2}{*}{$\begin{array}{l}\text { lo } \\
\text { subclass }\end{array}$} & \multirow{2}{*}{$\begin{array}{l}\text { Dilution } \\
\text { used }\end{array}$} & \multicolumn{3}{|c|}{ Adiut Muscle-call type: } & \multirow[t]{2}{*}{ Faterencia } \\
\hline & & & & Heart & Skeletal & Smooth & \\
\hline 9010 & Titin & $\lg M$ & $1: 10$ & + & + & . & Wang and Grewser, 1985 \\
\hline MF2O & Myosin & $\lg G 2 \mathrm{~b}$ & $1: 2$ & + & + & * & Masalki at al. 1982 \\
\hline $\mathrm{CH}$ & Tropomyosin & $\lg \mathrm{G} 1$ & $1: 10$ & + & + & $+\sqrt{1}$ & Lin at al. 1986 \\
\hline$s_{r} \cdot \|$ & Sarc. Actin & $\lg \mid \mathrm{M}$ & $1: 6$ & + & $*$ & 。 & Skatli at al 1988 \\
\hline$D E \cdot R \cdot 11$ & Desimin & $\lg 01$ & $1: 10$ & + & + & + & Dobus ot al. 1983 \\
\hline RCK106 & Keratin 18 & $\lg G 1$ & ud & - & - & - & Ramaekers ot al. 1987 \\
\hline CAME. 2 & Kerratin 8 & $\lg 62$ & $1: 10$ & - & - & - & Simadis ot al. 1990 \\
\hline RV 202 & Vimentin & $\lg G 1$ & wd & - & . & $4+$ & Ramagkers of al. 1987 \\
\hline
\end{tabular}

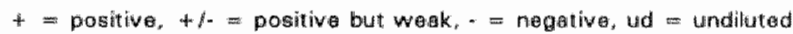

\section{Results}

Cross-reactivity of antibodies with adult rabbit tissues.

All monoclonal antibodies used in this study reacted with adult rabbit tissues in a fashion to be expected from their known staining patterns (Fig. 4.1; only stained sections of heart tissue are shown]. The monoclonal titin antibody (9D10) showed the typical double banded cross-striations in sections of adult 
rabbit heart and of skeletal muscle (Fig. 4.1a). Smooth muscle, epithelial cells and mesenchymal cells were negative. In sections stained with anti-myosin antibody MF20 (Fig. 4.1b), cardiac and skeletal muscle were positive with only a small number of the sarcomeres staining in a striated fashion. Smooth muscle cells were negative when stained with MF2O. Anti-tropomyosin antibody $\mathrm{CH} 1$ (Fig. 4.1 $\mathrm{c}$ ) gave a positive staining of all three types of muscle cells, with crossstriations in both cardiac and skeletal muscile cells. In smooth muscle cells a
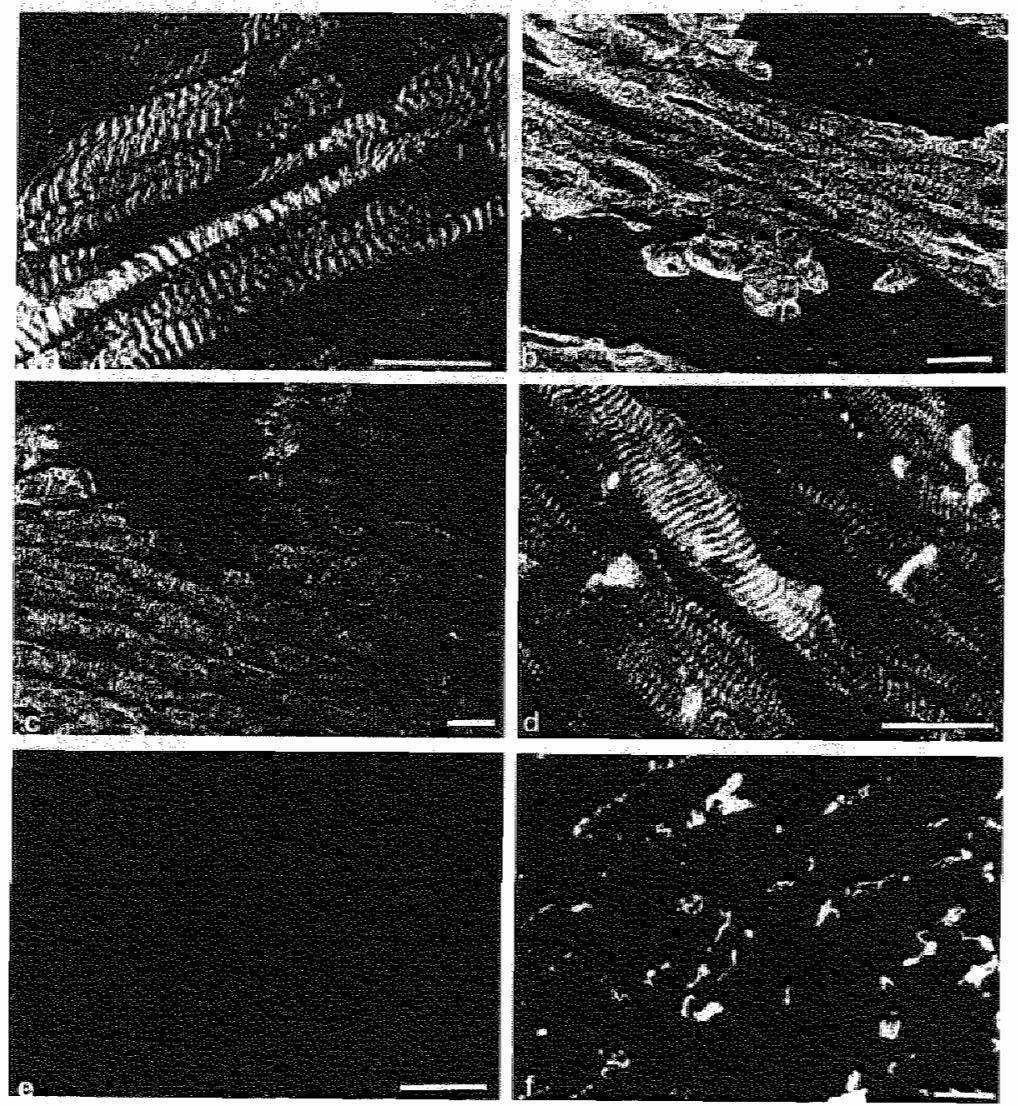

Fig. 4.1 a-f: Immunofluorescence micrographs of frozen sections from adult rabbit heart tissue. Sections ware incubated with monoclonal antibodies against a titin $19010 \%, b$ myosin (MF20), c tropomyosin (CH1), d desmin (DE-R-11), keratin (RCK106), and vimentin (RV202). Bars $20 \mu \mathrm{m}$. 
relatively weak reaction was found with $\mathrm{CH} 1$. Anti-sarcomeric actin as detected by antibody Sr-1 stained diffusely in cardiac and skeletal muscle cells and was negative in smooth muscle cells. DE-R-11, the desmin antibody showed crossstriations in both cardiac $\{$ Fig. 4.1d\} and skeletal muscle cells, and also stained the cytoplasm of smooth muscle cells. The anti-keratin 8 antibody CAM 5.2 was positive in columnar and cuboidal epithelial cells, for example those covering the small intestine but not in smooth, skeletal or cardiac muscle cells. RCK106, the keratin 18 specific antibody also stained these epithelial cells and was likewise negative for muscle cells (Fig, $4.1 \mathrm{e}$ ). No cross reactivity was found in cardiac or skeletal muscle cells with the monoclonal vimentin antibody RV202, but blood vessel endothelium and other mesenchymal cells, such as the interstitial fibroblasts stained strongly positive for vimentin (Fig. 4.1f). These results are summarized in Table 4.1.

\section{Embryonic development of the rabbit heart}

The first heart anlagen, the bilateral cardiogenic plates, are detectable in situ in the light microscope in early 3-somite embryos (Seidel 1960). From the moment that the primitive heart tubes are apparent in $8.5-\mathrm{dpc}$ embryos the differentiation of the tubes into atrium- and ventricle-like precursors is detectable. Pulsation starts in the 3-somite embryo (8.5 dpc; Dwinnell 1939). The individual heart tubes are still separated in these embryos (Dwinnell 1939). The tubes unite in 11 -somite-pair embryos, at $9.5 \mathrm{dpc}$, to form the segmented, four chamber heart (Seidel 1960).

\section{Cardiogenic plates $(0-1$ somite pairs; $\leq 8.0 \mathrm{dpc})$}

In the semi-thin sections of a 1-somite embryo, the localization of the heart anlagen are indicated in Fig. 4.2a and in a higher magnification in Fig. 4.2b. The topography of the two parts of the developing heart is based on the study of a series of semi-thin sections of the cardiac region of embryos at different developmental stages (not shown).

In the immunostained cryosections of the rabbit heart anlagen, the appearance of the first somite pair is accompanied with the expression of titin at the location of the developing embryonic heart (Fig. 4.2c). At no other place in the embryo titin is expressed at this stage. Titin dot-like aggregates are located throughout the entire cytoplasm of cells forming this initial stage of cardiomyogenesis. We also found a (weak) reaction with the myosin antibody in these embryonic hearts (Fig. 4.2d), with an appearance as dot-like aggregates and cytoplasmic filaments. Desmin is found in the mesoderm of the embryo, both medial and lateral of the heart anlagen, but also found within cells of the developing heart. At cellular level desmin is mainly found at the endodermal side of the cardiomyoblasts (Fig. 4.2e). Although there is intra-cellular coexpression of titin, myosin and desmin, no abvious colocalization of these proteins was seen at this stage. Vimentin and keratin show filamentous cytoplasmic staining patterns which frequently overlap (Fig. $4,2 f, g$ ). The monoclonal antibodies CAM 5.2 and RCK106 detected keratin filaments in the epithelial cells of the 
ectoderm and endoderm. The endocardial cells did not show a positive keratin reaction (Fig. 4.2f). Vimentin stained both the mesoderm and the myogenic cells, and a particullarly strong reaction was seen in the underlying endocard forming cells (Fig. 4.2g). No reaction was found with the tropomyosin (CH1) and actin (Sr-1) antibodies in the 0 to 1 -somite-pair embryos.
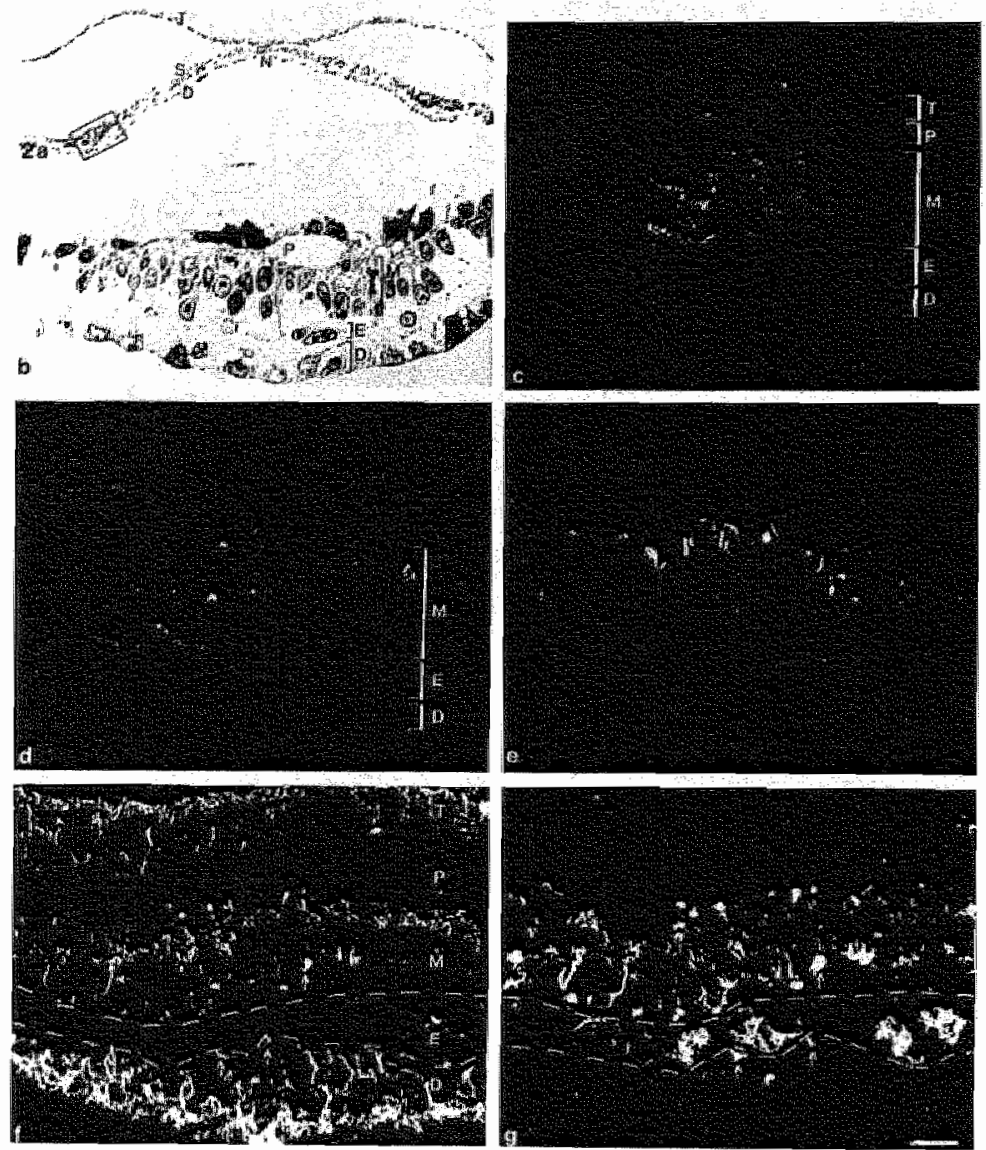

Filg. 4.2 a-f: Localization of the heart anlagen in semi-thin sections of a 1-somite rabbit embryo (a and bl. showing the bilateral localization of the first stages of heart development (a). Ectoderm and mesoderm are artificially separated due to the ambedding process. In higher magnification (b), the individual parts of the early rabbit heart are indicated. Immunofluorescence micrographs of frozen sections $(c-g)$, show c titin dots, d myosin dots and filaments, desmin, f keratiry and $g$ vimentin fillaments. Arrows indicate cells with coexpression of keratin and vimentin. Bar a $125, \mu m$; b: 20 $\mu \mathrm{m} ; \mathrm{c}-\mathrm{e} 12 \mu \mathrm{m} ; \mathrm{f} \sim \mathrm{g}: 40 \mu \mathrm{m}$. $\mathrm{D}$, endoderm; $\mathrm{E}$, endocard; $M$ myocard; $N$, notochord; $P$, pericardial cavity: $S$, mesoderm; $T$, ectoderm. 
Bilateral tubular heart anlagen (2-8 somite pairs; $8.0-9.0$ dpc)

In the next phase of embryonic development of the rabbit, when 4 somites are formed, the cardiogenic plates take on a U-shaped form which opens ventrally over the developing endocard. This stage of cardiogenesis shows the beginning of tropomyosin and actin expression, which are both organized in cytoplasmic filaments. Titin is present in dot-like aggregates in the periphery as well as filaments in the centre of the heart anlagen of the 4-somite embryos. Titin and desmin seem to occupy the same intracell domains frequently at this stage (Fig. $4.3 \mathrm{a}, \mathrm{b})$. Vimentin, myosin and keratin staining patterns did not change during the development of the 1-somite-pair to the 4-somite-pair embryo.

The first clear observation of colocalization of titin and desmin can be made in the 7-somite-pair embryos, where these two proteins are present in the same intracellular area (Fig. 4.3c,d). The intracellular distribution of titin depends on the localization of the cardiomyoblasts within the heart tubes: in medially

Table 4.2: $\quad$ Summary of immunohistochemistry in sections of the rabbit embryonic heart.

\begin{tabular}{|c|c|c|c|c|c|c|c|}
\hline \multirow[t]{2}{*}{ Antibody } & \multirow[t]{2}{*}{ Antigen } & \multirow{2}{*}{$\begin{array}{c}\begin{array}{c}\text { Cardiogenic } \\
\text { platers }\end{array} \\
(0-1 \text { som. })\end{array}$} & \multicolumn{2}{|c|}{$\begin{array}{l}\text { Bitaterall tubular } \\
\text { heart enlagen }\end{array}$} & \multirow{2}{*}{$\begin{array}{c}\begin{array}{c}\text { Modlially fused } \\
\text { heart tube }\end{array} \\
19-30 \text { som. }\end{array}$} & \multicolumn{2}{|c|}{$\begin{array}{c}\text { Segmented } \\
\text { heart } \\
\text { (> } 30 \text { Bom.) }\end{array}$} \\
\hline & & & {$[2-4$ som $]$} & $(6.8 \mathrm{som})$. & & $10 \mathrm{dpc}$ & $13 \mathrm{dpc}$ \\
\hline 9010 & Titin & $\mathrm{D}$ & $D, F$ & $D, F,(S)$ & F,S & $s$ & $s$ \\
\hline MF2O & Myosin & $D, F$ & D.F & $F$ & F,S & F.S & $F_{s} S$ \\
\hline $\mathrm{CHI}$ & Tiropomyosin & - & $\mathrm{F}$ & $\mathrm{F}$ & $F, S^{(2) \mid}$ & $s$ & $s$ \\
\hline $\mathrm{Sr} \cdot 1$ & Actin & . & $\mathrm{F}$ & $\mathrm{F}$ & $\mathrm{F}$ & $F$ & $F$ \\
\hline DE-R- $\| 1$ & Desmin & $F$ & $F$ & $F^{111}$ & $\mathrm{~F}$ & $F$ & F.S \\
\hline CAMS.2 & Keratin 8 & $F^{|3|}$ & $F^{(3)}$ & $\mathrm{p}^{(3)}$ & $F^{|3|}$ & $F^{[3]}$ & $F^{(3)}$ \\
\hline RCK 102 & Keratin 18 & $F^{13 ;}$ & $F^{(3)}$ & $F^{(3)}$ & $F^{|3|}$ & $F^{[3]}$ & $F^{(3)}$ \\
\hline RV2O2 & Vimentin & $F$ & $\mathrm{~F}$ & $\mathrm{~F}$ & $F$ & $\mathrm{~F}$ & $F^{(4)}$ \\
\hline
\end{tabular}

$D=$ dots; $F=$ filaments; $|S|=$ first indication of striation; $S=$ striation; - = negative.

(1): colocalization with titin (5-8 somite pairs).

(2): complementary location with titin $(\geq 12$ somite pairs).

(3): Myocard + /Endocard -

(4): Endocard + / Myocard: peripherally - and centrally +

located cells cytoplasmic titin filaments and the first signs of titin cross-striation are found, but laterally titin is still present as dots-like aggregates. The crossstriation of titin is shown in detail in Fig. 4.3h (arrows). Myosin and actin are 
now strongly expressed $(F i g .4 .3 e, f$ alongside with keratin and vimentin Inot shownl as flamentous structures, whereas tropomyosin expression is still weak (Fig. $4.3 \mathrm{~g}$ ).
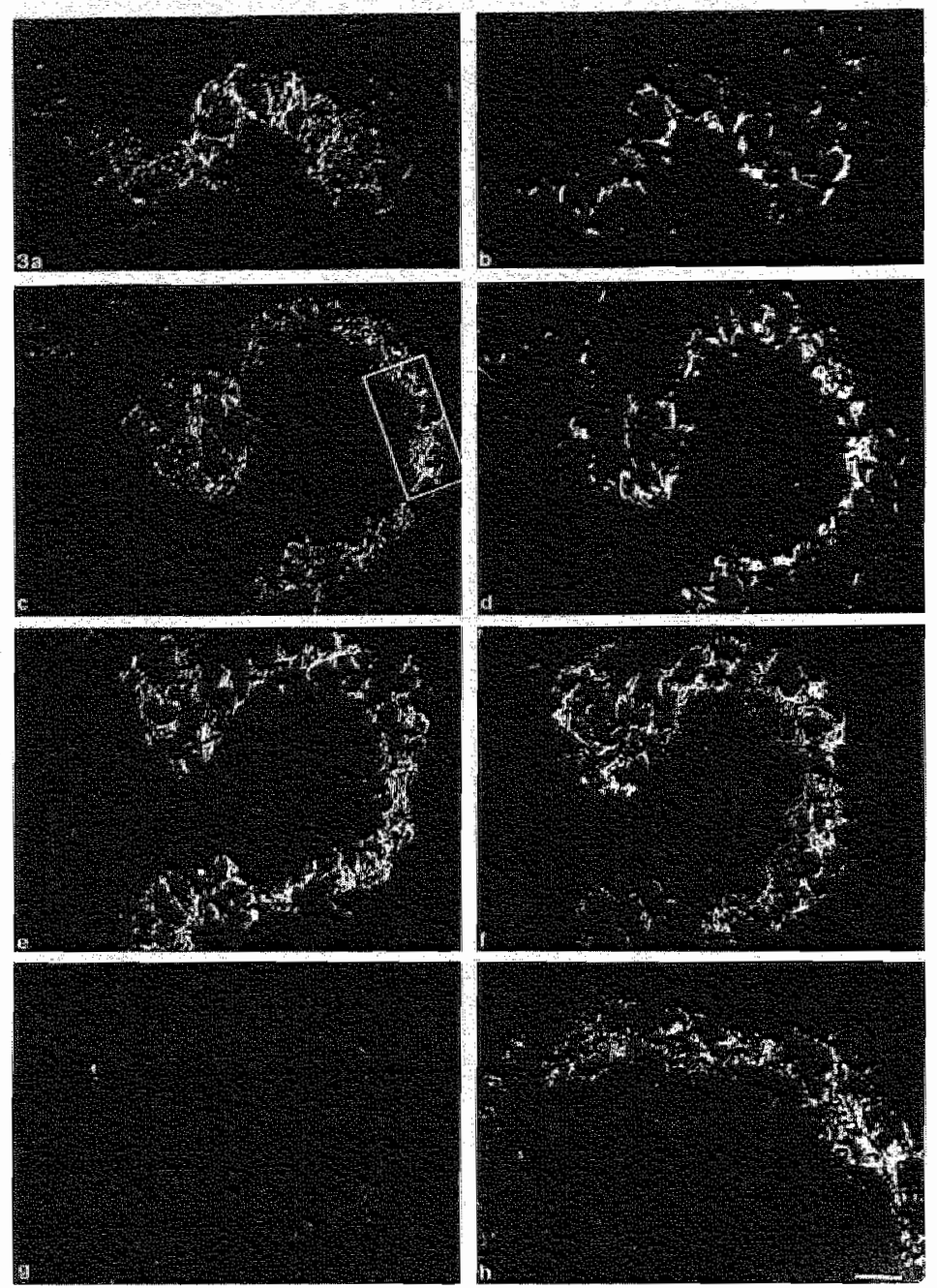

Fig. $4.3 \mathrm{a}-\mathrm{h}$ : Immunofluorescense micrographs of frozen sections of the heart anlagen of 4-somile- (a,b) and 7-somite- (ch) embryos, incubated with monoclonal antibodies against a $c$ titin, $b$ d desmin, myosin, actin and $g$ tropomyosin. and $b$, as well as $c$ and $d$ show double label immunafluorescence patterns of the same frozen section. Hh Higher magnification of the titin-stained heart anlagen, showing the first signs of crossstriation (arrow). Bar ab $18 \mu \mathrm{m} ; \mathrm{c}-\mathrm{g} 14 \mu \mathrm{m} ; \mathrm{h}: 10 \mu \mathrm{m}$. 
Medially fused heart tubes $19-30$ somite pairs; $9.0-10.0$ dpcl

The bilaterally developed heart parts approach and fuse between 9.0 and 10.0 dpc. As a result the formation of the segmented heart takes place. Initially, in the 9- to 12-somite embryo heart development is characterized by the crossstriation of tropomyosin in the cardiomyocytes (Fig. 4.4a, b; arrows) . Later, the transition of titin dot-like aggregates by filamentous and/or striated staining patterns is completed. From our study we therefore obtained the impression that tropomyosin, after titin, is the second protein that is organized in a striated pattern, but no colocalization of these proteins was found In fact the organization of titin and tropomyosin seemed complementary. Myosin shows first indications of cross-striation at this stage (Fig. $4,4 \mathrm{c}, \mathrm{d}$; arrows), but the major part is still within the cytoplasm in a filamentous or diffuse form. The other proteins investigated all show a filamentous organization as shown before.
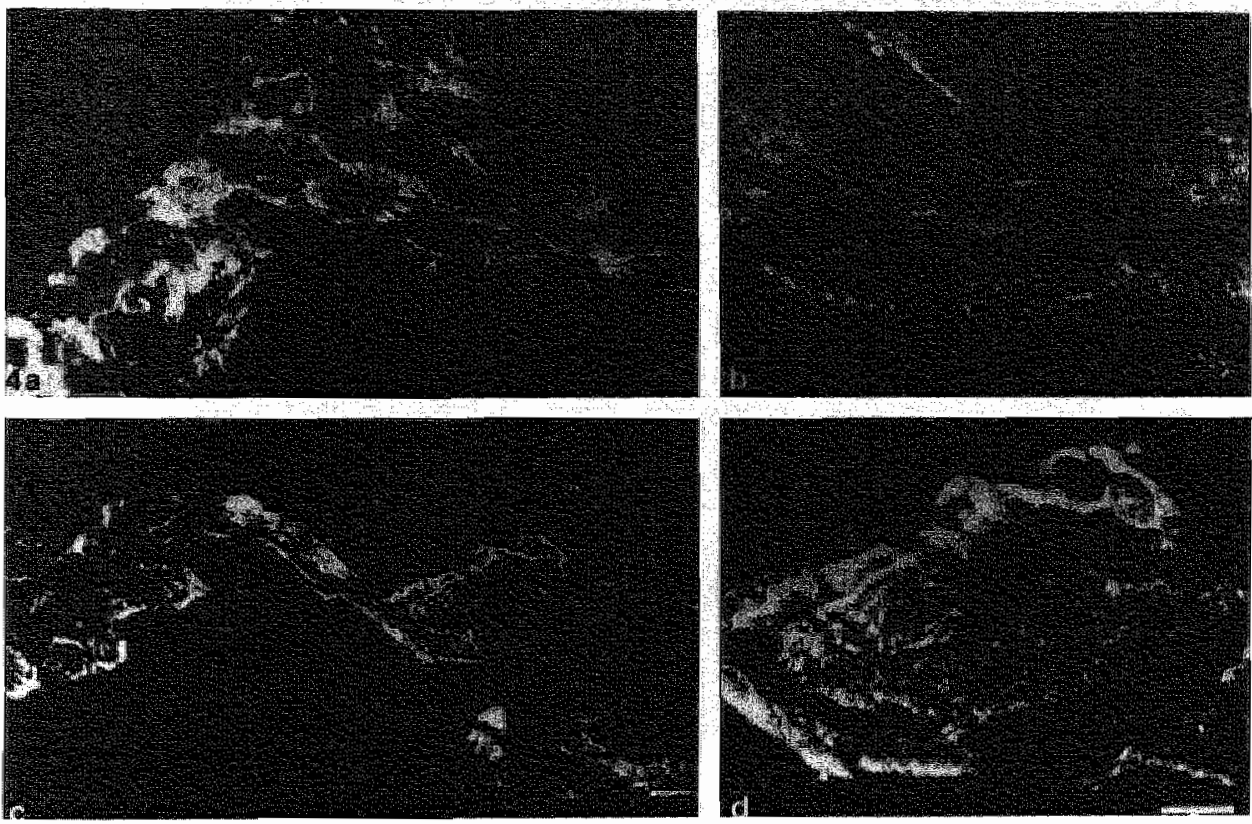

Fig. 4.4a-d Immunofluorescence micrographs of frozen sections of the developing heart after medial fusion of the heartubes $(9-10$ 30-somite embryos; 9 dpc), incubated with monoclonal antibodies to tropomyosin $(a, b)$ and myosin $(c, d)$, showing cross-striation for both proteins larrows》. Bar indicates: $a_{1} \mathbf{c} 14 \mu \mathrm{m} ; \mathrm{b}, \mathrm{d} 7 \mu \mathrm{m}$.

Segmented heart lover 30 somite pairs; $10.0-13.0 \mathrm{dpcl}$

In the segmented heart of 10-dpc embryos (over 30 somites) the atria and ventricles are clearly detectable. Both titin and tropomyosin seem to be fully organized at the cellular level resulting in cross-striated staining patterns only in 
sections of the 10-dpc heart. The complementary organization of these two proteins that was observed in the previous phase, is seen again in these later stages. Myosin and actin tilaments are present but there is no evident sign of striation or advanced organization yet. In the myocaird desmin and keratin filaments are coexpressed. Endocardial cells are positive for vimentin (Fig. 4.5b), but negative for all other proteins investigated here, e.g. titin (Fig. 4.5a).

In 13-dpc embryos titin is cross-striated throughout the entire heart musculature (Fig. $4.5 a, c, f)$. Within the individual fibrils two fluorescent lines are seen close to the M-line in every sarcomere (Fig. 4.5f). The strong tropomyosin signal is found in the sarcomeres in this embryo in a cross-striated pattern. The complementary location of titin and tropomyosin in the sarcomeres is also seen in the sections of this phase (not shown). Although there were signs of initiating myosin crossstriation in earlier embryos, the organization of this protein is still not evident in this stage. There was no actin striation detectable with the monoclonal antiserum $\mathrm{Sr}-1$ we have used in this study. The re-organization of desmin from a filamentous into a cross-striated pattern starts between 10 and $13 \mathrm{dpc}$. The cardiomyocytes of $13-\mathrm{dpc}$ embryos show to a large extent desmin striation when examined with the antibody DE-R-11 (Fig. 4.5d; arrows), but in some parts desmin filaments are still seen. Titin and desmin double-stained sections of 13 dpc embryonic heart show that the titin positive double-banded pattern does not colocalize with the striated desmin pattern (Fig. 4.5f,g; arrows). The desmin banding patterin fals between the narrow gap of the titin staining pattern.

Keratin filaments, as in earlier stages, are found in the myocard but not in the endocard (not shown). Vimentin, apart from being expressed in the endocard IFig. 4.5el, shows the following differentiation in the myacard: the muscle cells of the ventricular wall are negative for vimentin, whereas central parts of the myocard, possibly the precursor papillary muscles, are weakly but defenitely positive with the vimentin antibody we have used (Fig. 4.5b).

The results of the immunofluorescense assays on sections of the rabbit embryonic heart anlagen are summarized in Table 4.2.

\section{Discussion}

The expression and organization of muscle-specific proteins in rabbit embryos The earliest specific differentiation marker for rabbit cardiomyogenesis detected in this study is titin, symthesized in the heart anlagen of the 1-somite embrya. This protein re-organizes from dotulike aggregates to a striated fashion via cytoplasmic filaments. In comparison. the thick filament protein myosin is also present in the early rabbit heart anlagen, but the organization of this protein in a striated fashion seems to occur much more slowly as compared to titin organization. The expression of tropomyosin, a thin filament-related protein, first started in 2- to 4-somite embryos together with actin, and thus later than the first expression of titin. The striation pattern, however, was completed at the same stage as the titin organization in the 13-dpc embryos. With antisera to 
these two proteins, the banded staining patterns of titin and tropomyosin appeared to be complementary. Desmin flaments were already found in some mesodermal cells in the rabbit embryos before the heartantagen were
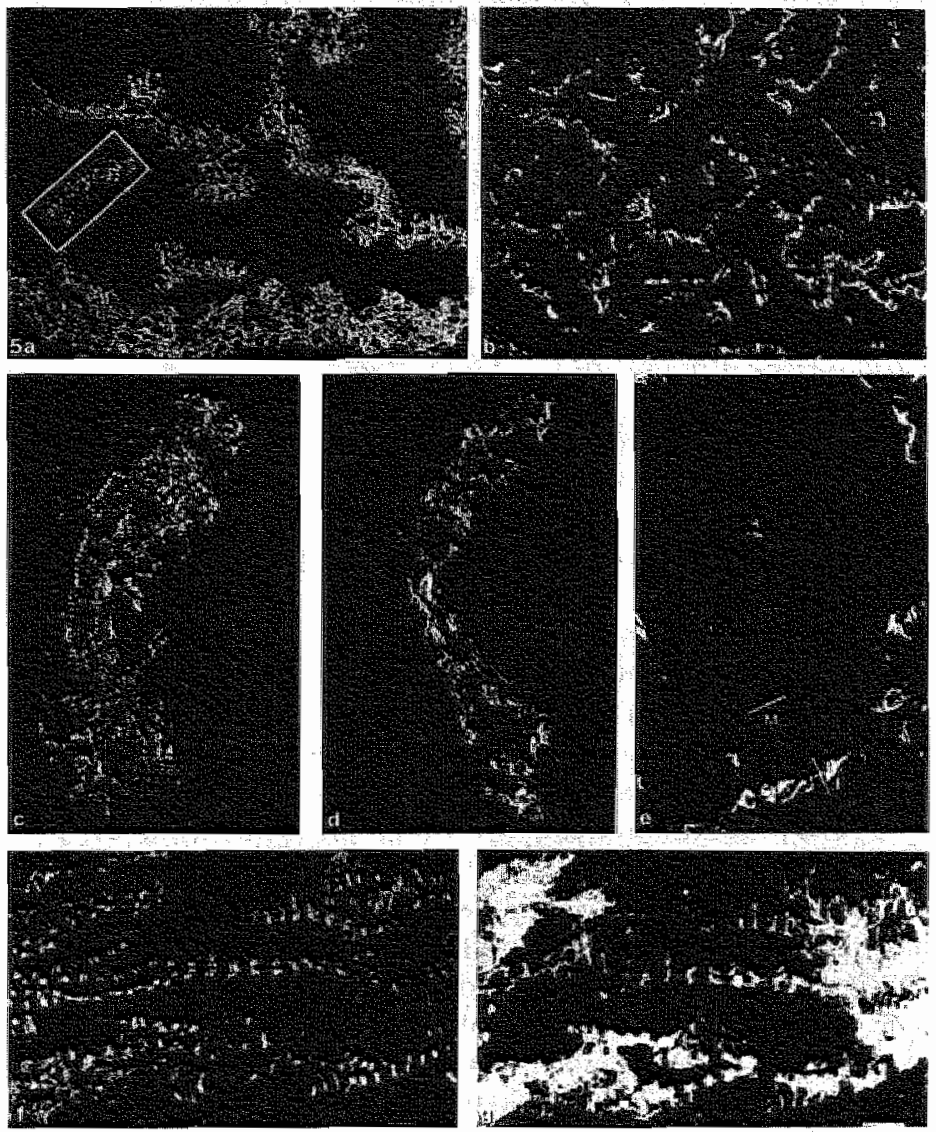

Fig. $4.5 \mathrm{a}-\mathrm{g}$ " Double immunofluorescence micrographs of frozen sections of the heart of 13-dpc embryos $1>30$ somites/, incubated with monoclonal antibodies against titin and lb vimentin. Single asterisks indicate central part of the myocard; double asterisks indicate peripheral part of the myocard. The boxed area in andicates the area that is

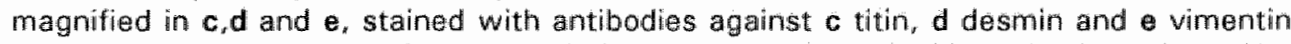
(arrows in dindicate desmin cross-striation; $c$ and show double-stained section). The double stained section incubated with titin and subsequently g desmin shows that there is no colocalization of these proteins at this stage of development larrows indicate titin-positive but desmin-negative locations). Bar a,b: $45 \mu \mathrm{m} ; \mathrm{c}-\mathrm{e} 10 \mu \mathrm{m} ; \mathrm{f.g} 6 \mathrm{\mu m}$. $\mathrm{M}$, myocard; E, endocard. 
detectable. Striation of desmin was found only late in some parts of the segmented heart, at 13 dpc. Keratins and vimentin are already present in presomite embryos as fllaments and remain flamentous during early embryonic heart development, until the stage of the segmented heart is reached. Keratins were exclusively found in the myocard of the rabbit heart, and vimentin is mainly located in the endocard.

The major differences between 13-dpc embryonic and adult heart tissue as detected in this study are the fllamentous organization (for the most part) of actin in embryos (2- to 4- somites or older) in contrast to the diffuse staining pattern in heart tissue of adult rabbits, and the expression of positive vimentin and keratin staining in embryonic heart tissues.

\section{Markers for the early detection of cardiomvogenesis}

The first question addressed in this study was whether the use of musclespecific antibodies made it possible to detect the heart anlagen in rabbit embryos earlier then in the 3-somite pair embryo, when morphologically the first sign of cardiomyogenesis has been described by Seidel (1960). Studies on the cardiomyogenesis in the mouse (Schaart et al. 1989) indicated that two musclespecific proteins are powerfull potential markers for this purpose, i.e. titin. a marker in adult striated muscle (Wang et al. 1979) and desmin, a muscle-specific intermediate filament component in adult vertebrates (Hill et al. 1986). Titin was found very early in the developing heart anlagen of mouse embryos, before overt histological signs of cardiogemesis are seen. Desmin was found in the mouse neuro-ectoderm first, and a few hours later was found only in the heart anlagen. a short period after the expression of titin had been initiated. As in mouse, desmin expression is not restricted to the heart in the rabbit as there is desmin reactivity in mesodermal cells during the entire developmental period we have investigated (Viebahn et al.,unpublished). Desmin in the rabbit is therefore not specific for early heart dewelopment. The early and specific expression of titin on the contrary is exclusive to the heart anlagen, already in 1-somite embryos, at a time when cardiogenesis is just seen histologically (Fig. 4.2a,bi), but not macroscopically (Seidel 1960). Similar to the situation in the mouse, titin seems to be one of the first known cardiac muscle-specific markers to be expressed. Therefore, it is possible to use the striated muscle-specific protein titin as a marker for early cardiogenesis in the rabbit, just as in the chick and mouse Tokuyasu and Maher 1987a,b; Schaart et al. 19891. The expression of titin dotlike aggregattes appears at an earlier developmental phase in the rabbit, as compared to the chick or the mouse embrya. where the expression of this protein starts at about the 4-somite stage (Tokuyasu and Maher 1987a; Fürst et al. 1989; Schaart et al. 1989). Using antibody 03 , which recognizes desmin in a stage dependent manner (Fischman and Danto 1985). Baldwin et al. (1991) found expression of this IFP already in heart forming mesoderm of the rat at earlier stages than studied in the rabbit and the mouse sofar. However, the beginning of titin expression remains to be determined in this species. 


\section{Titin and myosin organization}

The pattern of titin rearrangement from dots to a striated pattern (Tokuyasu and Maher 1987a; Schaart et al. 1989) is similar in chick. mouse and rabbit: the dotlike aggregates become gradually organized into cytoplasmic filaments and later develop into a banded pattern. In the 13-dpc embryos a double striation pattern within the sarcomeres was found. The formation of a pair of delicate lines per sarcomere is a titin-specific quality that is found with most antibodies (Fürst et al. 1988\%. This titin-specific pattern is a result of its molecular size and its intrasarcomeric location. The carboxy-terminus of titin is located at the $Z$-line regions and the amino-terminal end near the M-line (Wang et al. 1991).

The appearance of titin dots in the heart anlagen in the 1-somite embryos coincides with the first expression of myosin at this location. The observation of the linked initiation of titin and myosin expression during myofibrillogenesis in embryonic chick skeletal muscle cultures was reported by Hill et al. (1986). These authors also reported a tight temporal and topographical linkage of these two proteins. This linkage is, however, questioned by Tokuyasu and Maher (1987a) who postulate that there is a temporal but not al topographical interaction between these markers in chick. The present study indicates a transient link between titin and myosin in the very early stages of rabbit heart development. The topographical linkage, however, is not cleat, possibly because of the sometimes diffuse reaction pattern of the myosin antibody we have used. Cantraction of the cardiac muscle starts in the 3-somite-pair embryos (Dwinnel 1939). At this stage myosin and titin are not yet organized in striated patterns, although titin re-organization has already started: apart from dot-like aggregates titin filaments are present. Myosin organization therefore does not seem to be essential for the initiation of muscle contraction.

\section{Actin and tropomyosin organization}

The elements of thin fillaments we have investigated, i.e. tropomyosin and actin, show no detectable regular organization at the stage of heart development where muscle contraction starts (in 3-somite embryos). Tropomyosin organization into a striated pattern only starts after the heart has begun to contract (in 9- to 12-somite embryos). It is very well possible that the actin organization into sarcomeres is partly completed before or at this point. Such a structural assembly was, however, not recognized by the antiserum we have used, although it is an anti-sarcomeric actin antibody reacting strongly in adult striated rabbit muscle (Skalli et al. 1988).

We have to conclude that there is no correlation between the initiation of the contractions and the intrasarcomeric organization of contractile proteins myosin and actin. The fact that myosin assembly into a striated pattern is only detected in some parts of older embryos, that did already contained contracting segmented hearts, supports this statement.

Double staining experiments on the heart of 13-dpc embryos, show that titin and tropomyosin are located in a complementary manner. This organization confirms that the titin antiserum marks the epitope at the A-I junction, and that 
tropomyosin is connected with the thin, actin filaments that are the most mportant components of the Imband in mature sarcomeres (Wang and Greaser 19851 .

\section{Desmin and vimentin organization}

The expression of desmin in the rabbit embryo is not exclusive to the developing heart, but is also found in some mesodermal cells. This is different from the desmin expression pattern seen in the developing mouse embryo, where this IFP is first expressed in the neuro-ectoderm (Schaart et al. 1989), but a few hours later, after the start of the titin expression, is exclusively found in the heart anlagen.

In the rat, just as in the rabbit. desmin is not exclusively found in the theart anlagen but also present in other mesodermal tissue. Desmin and myosin expression appear to be initiated simultanously in rat heart (Baldwin et al. 1991). In the rabbit, desmin can already be demonstrated before myosin expression can be detected.

In the differentiating rabbit cardiac muscle cells, desmin undergoes a redistribution from a cytoplasmic, filamentous localization to being associated with myofibrils, expressed by a striated staining pattern, and later, in adult heart tissue, with Z-lines and/or intercalated disks. This redistribution schedule was also found in the Syrian hamster (Osinska and Lemanski 1989) and in the mouse (Schaart et al. 1989). Although there seemed to be an intracellular topographical linkage of titin and desmin in the heart anlagen of 7-somite-pair embryos, only in the older hearts intracellular coexpression of these proteins was observed. Titin and desmin are complementary organized: the titin epitope that is recognized by the antibady we have used is found at the A.l junction, while desmin is conmected with the Zalines.

\section{The relation of vimentin, desmin and keration expression}

In the repart of Osinska and Lemanski (1989) the presence of vimentin filaments in embryonic, new-born and adult cardiac tissue in Syrian hamster was described. In the rabbit, vimentim filaments were found in embryo hearts but not in adult cardiac tissue. In contrast to the early mouse heart anlagen (Furst et al. 1989; Schaart et al. 1989), no cross-striation of vimentin is found in the rabbüt heart. Vimentin was found in the endocardial cells after the fusion of the bilaterally developed heart tubes to form the segmented, four-chamber heart. The presence of vimentin in the endocard is equivalent to its presence in endothelium (Viebahn et al. 1988) and was also found in the mouse (Schaart et al. 1989). The disappearance of vimentin from venticle wall earlier than from papillary precursors might point to slower development of the latter. The vimentin expression is problably down-regulated in later stages of embryogenesis, since the myocard is rotally vimentin-negative in adult rabbit. Vimentin apparently does not interfere with maturation during myogenic differentiation. 
In the mouse the myocardial cells co-express vimentin and keratin at first, and are positive for desmin, vimentin and keratin a few stages later. Keratin expression in the myocard of mouse embryos decreased and disappeared completely before the myocardial cells lost wimentin expression. Although the myocardial cells were already negative for vimentin, keratin expression was retained in the rabbit embryos we have studied. Similar results on the presence of keratin in the myocardial cells of human and chick embryos were obtained by Kuruc and Franke (1988). It is likely that the loss of myocardial keratin expression takes place in older embryos or in new-born rabbits, because the adult rabbit hearts were negative for keratin.

\section{Conclusions}

An important conclusion of this study is that the organization of titin, tropomyosin, myosin and desmin into a striated pattern does not seem to be essential for the initiation of the muscle contraction in the heart anlagen. The first muscle contractions can be found in 3-somite embryos, when the developing heart tubes are still separated. The organization of the above mentioned proteins into cross-striated patterns, however, was found in later stages.

Comparing the results of the studies in the chick (Tokuyasu and Maher 1987a), the mouse (Schaart et al. 1989), the Syrian hamster 1Osinska and Lemanski 1989), rat (Baldwin et al. 1991) and the rabbit, the conclusion can be made that cardiac expression of muscle-specific proteins and IFP is dependent on the species, the developmental stage and the topographical location within the heart. Apart from the onset of titin expression, the sequence of expression of several muscle-specific proteins and/ or IFP is species dependent, as is stage at which expression of these proteins in specific regions of the heart is lost.

Acknowledgement. Part of this work was supported by the Dutch Heart Foundation and the Deutsche Forchungs Gemeinschaft (Wa 359-9).

\section{References}

1. Bader, D., Tomoh, M. and Fischman, D.A. (1982). Immunohistochemical analysis of myosin heavy chain during avian myogenesis in vivo and in vitro. $\downarrow$. Cell Biol. 95:763-770.

2. Baldwin, H.S., Jensen, K.L. and Solursh, M. (1991). Myogenic cytodifferentiation of the precardiac mesoderm in the rat. Differentiation $47: 163$. 172. 
3. Danto, B.l. and Fischman D.A. (1984). Immunocytochemical analysis of intermediate filaments in embryonic heart cells with monoclonals to desmin. $J$. Cell Biol. 98:2179-2191.

4. Debus, E. Weber, K. and Osborn. M. 119831. Monocional antibodies to desmin. the muscle-specific intermediate filament. EMBO J. 2:2305-2312.

5. Dwinnell, L.A. (1939). Physiological contraction of double hearts in rabbit embryos. Proc. Soc. Exp. Biol. Med. 42:264-267.

6. Fischman, D.A. and Danto, S.I. (1985). Monoclonal antibodies to desmin: Evidence for stage-dependent intermediate filament immunoreactivity during cardiac and skeletal muscle development. Ann. N.Y. Acad. Sci. 455:167-184.

7. Fischman, D.A. (1986). Myofibrilliogenesis and the morfologenesis of skeletal muscle. In: Engel, A.G. and Banker, B.Q. (eds) Myology: Basic and Clinical. McGraw-Hill, New York, pp. 5-30.

8. Franke, W.W., Grund, C., Kuhn, C., Jackson, B.W. and Illmensee, K. (1982). Formation of cytoskeletal elements during mouse embryogenesis. III. Primary mesenchymal cells and the first appearance of vimentin filaments. Differentiation 23:43-59.

9. Franke, W.W. and Moll, R. (1987). Cytoskeletal components of lymphoid organs. 1. Synthesis of cytokeratins 8 and 18 and desmin in subpopulations of extrafollicular reticulum cells of human lymph nodes, tonsils and spleens. Differentiation 36:145-163.

10. Fulton, A.B. and W.B. Isaacs (1991). Titin, a huge, elastic sarcomeric protein with a probable role in morphogenesis. BioEssays 13(4):157-161.

11. Fürst, D.O., Osborn. M., Nave, R. and Weber, K. (1988). The organization off titin filaments in the half-sarcomere rewealed by monoclonal antibodies in iimmuno-electronmicroscopy: a map of ten nonrepetitive epitopes starting at the Z-line extends close to the M-line. J. Cell Biol. 106:1563-1572.

12. Fürst, D.O., Osborn, M. and Weber, K. (1989). Myogenesis in the mouse embryo: differential onset of expression of myogenic proteins and the involvement of titin in myofibril assembly. J. Cell Biol. 109:517-527.

13. Greaser. M.L., Handel, S.E., Wang, S.-M. Schultz, E., Bulinski, J.C. and Lessard. J.L. (1989). Assembly of titin, myosin, actin and tropomyosin into myofibrils in cultured chick cardiomyocytes. In: Stockdale, F. and Kedes, L. (eds). Cellullar and Molecular Bilology of Muscle Development. UCLA Symposium on Molecular and Cellullar Biology, New Series, Vol.93, Alan R. Liss, New York, pp. 246-257.

14. Handel, S.E., Wang, S.-M., Greaser, M.L., Schultz, E., Bulinski, J.C. and Lessard, J.L. (1989). Skeletal muscle myofibrillogenesis as revealed with a monoclonal antibody to titin in combination with detection of the alpha and gamma isoforms of actin. Dev. Biol. 132:35-44.

15. Hill. C.S., Duran, S., Zhongxiang, L., Weber, K. and Holtzer, H. (1986). Titin and myosin, but not desmin, are linked during myofibrillogenesis in postmitotic mononucleated myoblasts. J. Cell Bial. 103: 2185-2196.

16. Jackson, B.W., Grund, C. Winter, S., Franke, W.W. and Illmensee, K. (1981). Formation of cytoskeletal elements during mouse embryogenesis. II. Epithelial differentiation and intermediate-sized filaments in early post-implantation embryos. Differentiation $20: 203 ; 216$

17. Jong. F. de. Geerts, W.J.C., Lamers, W.H., Los, J.A. and Moorman, A.F.M. 11990). Isamyosin expression pattern during formation of the tubular chicken heart: a three dimensional immunohistochemical analysis. Anat. Fiec. 226:213227 .

18. Karnovsky, M.J. (1965). A formaldehyde - glutaraldehyde fixative of high osmolarity for use in electron microscopy. JCB 27:137 A-138A.

19. Kuruc, K. and Franke. W.W. (1988). Transient coexpression of desmin and cytokeratins 8 and 18 in developing myocardial cells of some vertebrate species. 
Differentiation 38:177-193.

20. Lazarides, E. and Hubbard, B.D. (1976). Immunological characterization of the $100 \AA$ filaments from muscle. Proc. Natl. Acad Sci USA 76:43444348.

21. Lemanski, L.F. 11979\%. Role of tropomyosin in actin fillament formation in embryonic salamander heart cells. J Cell Biol. $82: 227-238$.

22. Lin, J.J.C.C. Chou, C.-S. and Lin, J.L.-C. (1985). Monoclonal antibodies against chicken tropomyosin isoforms: production, characterisation and application. Hybridoma 4:223-242.

23. Lyons, G.E.. Ontell. M, Cox, R., Sassoon, D. and Buckingham, M. (1990a). The expression of myosin genes in developing skeletal muscle in the mouse embrya. J. Cell Biol. 111:1465-1476.

24. Lyons, G.E., Schaffino, S., Sassoon, D. Barton, P. and Buckingham, M. (1990b). Developmental regulation of myosin gene expression in mouse cardiac muscile. J. Cell Biol. 111:2427-2436.

25. Lyons, G.E., Buckingham, M.E. and Mannherz, H.G. (1991). a-actin proteins and gene transcripts are colocalized in embryonic mouse muscle. Development $111: 451-454$.

26. Masaki, T., Bader, D.M., Reinach, F.C., Shimizu, T., Obinata,T., Shatiq S.A. and Fischman D.A. (1982). Monoclonal antibody analysis of myosin heavy chain and the protein isoforms during myogenesis. In: Pearson, M., Epstein, H. Kaufman and Garrels, J.L. (eds). Molecular and cellular control of muscle development. Cold Spring Harbor Lab Press,pp. 405-417.

27. Maruyama, K. (1986). Connectin, an ellastic filamentous protein of striated muscle. Int. Rev. Cyt. 104:81-114.

28. Molengraft, F. van de, Ramaekers, F.C.S., Jap, P., Vooijs. P. and Mungyer, G. (1986). Changing intermediate-fillament patterns in metastatic hepatocellular carcinoma cells of the guinea pig. Virchows Arch B 51:285-301.

29. Muijen van, G.N.P., Ruiter, D.J. and Warnaar, S.O. (1987). Coexpression of intermediate filament polypeptides in human fetal and adult tissues. Lab. Invest. 57:359-369.

30. Osborn, M. and Weber, K. (1982). Ummunofluorescence and immunocytochemical procedure with affinity purified antibodies: tubulincontaining structures. Meth Cell Biol. 24:97-132.

31. Osinaka, H.E. and Lemanski L.F. (1989). Immunofluorencent lacation of desmin and vimentin in developing cardiac muscle of syrian hamster. Anat. Rec. 223:406-413.

32. Ramaekers, F.C.S., Huysmans, A., Schaart, G., Moesker, O. and Vooijs, G.P. $11987)$. Tissue distribution of keratin 7 as monitored by a monoclonal antibody. Expl Cell Res. 170:235-249.

33. Sassoon, D.A., Garner, 1. and Buckingham, M. (1988). Transcipts of a-cardiac and $a$-skeletal actins are early markers for myogenesis in the mouse embryo. Development 104:155-164.

34. Schaart, G., Viebahn, C., Langmann, W. and Ramaekers, F.C.S. (1989). Desmin and titin expression in early postimplantation mouse embryos. Development 107 : 5.5-596.

35. Schaart, G., Pieper, F.R., Kuijpers, H.J.H., Bloemendal, H. and Ramaekers, F.C.S. (1991). Baby hamster kidney (BHK-21/C13) cells can express striated muscle type proteins. Differentiation 46:105-115.

36. Seidel, F. (1960). Die Entwicklungsfähigkeiten isolierten Furchungszellen aus dem Ei des Kaninchens Oryctolagus cuniculus. In: Romeis, B. and Kühn, A. (eds.). Wilhelm Raux" Archiv für die gesamte kausale Morphologie, 152. band. Springer-Verlag, Berlin /Göttingen/Heidelberg, pp.:43-127.

37. Skalli, O., Gabbiani, G., Babai, F., Seemayer, T.A., Pizzolato, G. and Schürch, W. (1988). Intermediate filament proteins and actin isoforms as markers for soft 
tissue tumor differentiation and origin. II. Rhabdomyosarcomas. Am. J. Pathol. $130.513-531$.

38. Smedts, F "Ramaekers, F., Robben, H. Pruszciynski, M., van Muijen, G., Lane, B., Leigh, I. and P. Vooils 11990). Changing patterns of keratin expression during progression of cervical intraepithelial neoplasia. Am. J.Pathol, 136:657.668.

39. Tokuyasu, K.T. and Maher, P.A. 1987a). Immunocytochemical studies of cardiac myofibrillogenesis in early chick embryos. I. Presence of immunofluorescent titin spots in premyofibrit stages. J. Cell Biol. 105:2781. 2793.

40. Tokuyasu, K.T. and Maher. P.A. (1987b). Immunocytochemical studies in early chick embryos. Il. Generation of a-actinin dots within titin spots at the time of the first myofibril formation. J. Cell Biol. 105:2795-2801.

41. Traub, P. (1985). Intermediate filaments. A review. Springer-Verlag. Berlin/ Heidelberg/ New York/ Tokyo, pp.:2-17.

42. Trombitas, K., Baatsen, P.H.W.W., Lin, J.J.-C., Lemanski, L.F. and Pollack, G.H. (1990). Immunoelectron microscopic observations on tropomyosin localization in striated muscle. J. Muscle Res. and Cell Mot. 11:445-452.

43. Viebahn, Ch., Lane, E.13. and Ramaekers, F.C.S. (1988). Keratin and Vimentin expression in early organogenesis of the rabbit embryo. Cell Tissue Res. $253.553-562$.

44. Wang, K., McClure, J. and Tu, A. 11979). Titin: Major myofibrillar components of striated muscle. Proc. natn. Acad. Sci. U.S.A. 76:3698-3702.

45. Wang. S.M. and Greaser, M.L. (1985).Immunocytochemical studies using a monoclonal antibody to bovine cardiac titin on intact and extracted myofibrils. $J$. Muscle Res. Cell. Motil. 6:293-312.

46. Wang, S.-M.. Greaser. M.L., Schultz, E., Bulinski J.C., Lin J.J.-C. and Lessard, J.L. (1988). Studies on cardiac myofibrillogenesis with antibodies to titin, actin, tropomyosin and myosin. w. Cell Biol. 107:1075-1083.

47. Wang, S.-M., Sun, M.-C. and Jeng, C.-J. (1991). Location of the C-terminus of titin at the $Z$-line region in the sarcomere. Biochem. Biophys. Res. Commun. 176:189-193. 
Rearrangement of intercellular junctions and cytoskeletal proteins during rabbit myocardium development.

Frank T.L. van der Loop, Gert Schaart, Helma Langmann,

Frans C.S. Ramaekers and Christoph Viebahn.

European Journal of Cell Biology (1995) 68: 62-69.

A direct and close association between desmosomes and intermediate-sized filaments of the keratin type exists in embryonic and in adult epithellial tissues. Cardiomyocytes are interconnected by spot-desmosomes, which are-found in the intercallated disks and can be immunocytochemicically detected by antibodies to desmoplakins. In this study at the light-microscopical level we describe an interaction of keratin filaments with desmoplakins during rabbit myocardiogenesis. In the early stages (0-1 somites), desmoplakins are more abundant in the heart anlagen than in the adjacent intra- and extraembryonic mesoderm. During development of the myocardium, desmoplakins expression gradually rearranges from a apicolateral- into an intercalated disks localization in later stages. Keratin expression in the developing myocardium of the rabbit heart decreases with the age of the embryo. Keratin filaments are gradually lost via dot-like aggregates which colocalize with desmoplakin-positive clusters. Our results suggest a role for keratins in the developmental rearrangement of desmoplakins into the intercalated discs. A direct relation of desmin and titin reorganization to desmoplakin rearrangement, which was examined because of the dominant role of these proteins in cardlogenesis, was not found.

\section{Introduction}

During development of the myocardium a typical program of cytoskeletal protein expression comes into effect $\llbracket 4,13,19,29,32,34 \rrbracket$ Specific proteins, e.g. titin and desmin, are early myogenic markers that are increasingly expressed and 
rearranged along with heart muscle cytodifferentiation $[28,29,34]$ while other, initially strongly expressed cytoskeletal proteins (e.g. vimentin and keratin), are gradually lost $\llbracket 19,34 \rrbracket$. Vimentin and keratin are typically found in coelomic epithelium from which the myocardium is derived. The gradual loss of vimentin takes place first in peripheral parts of the myocardium and later in the more centrally located cells [34], which may be explained by a simple differentiation gradient stretching from peripheral to central. The change of keratin expression, on the other hand, is more complex. In the cardiac tube, keratin changes from a filamentous into a dot-like pattern. The exact time range during which downregulation of keratin expression occurs as well as the nature of its reorganization have not been determined yet. Kuruc and Franke [19] have described that keratin is arranged in a dot-like pattern in heart muscle cells before it is lost. As there is a relation between keratins and intercellular junctions $[1,9]$, even in embryonic tissues $[9,16,17]$, we examined whether or not such a relation exists in the developing heart.

In the adult heart the cardiac muscle cells are interconnected by spot desmosomes which are grouped together in the intercalated disks [10]. These desmosomes are characterized by a proteinaceous plaque $115-20 \mathrm{~nm}$ thick) at the cytoplasmic face of the plasma membrane and fibrous transmembrane linker proteins, for example desmoglein and desmocollins [2], that extend from these plaques into the intracellular space. The major components of the cytoplasmic plaque of the desmosomes are desmoplakin $\mid(M w 250 \pi \mathrm{KD})$ and desmoplakin II (Mw $215 \mathrm{kD}$ ) [22]. These polypeptides occur in equimolar amounts in the plaques and are biochemically and immunologically related [11]. The linker proteins form an interlocking network that connects the cells. The intracellular face of the cytoplasmic plaques comprises anchorage sites for intermediate-sized filaments, such as the keratin filaments in epithelial cells and desmin filaments in heart muscle cells [18], which exhibit a side-on attachment to these plaques. Franke and co-workers [10] showed that the desmoplakins of epithelial and myocardial desmosomes are closely related, both biochemically and immunologically. Therefore questions arose about the relation of cardiac desmoplakins and the myogenic cytoskeletal protein desmin, present in the Zlines in adult myocardium $[6,23,28]$, and titin, a major heart- and skeletal muscle specific protein [13].

Analysis of these questions might in addition, elucidate how during cardiogenesis, the polarity of the myocardium precursor cells (coelomic epithelium) changes from an apical to basal organization into the polarity spanning between the laterally orientated intercalated disks, which is typical for the connection between the adult cardiomyocytes.

Therefore, in this study we have characterized the relation between the expression of desmoplakin, the loss of keratin expression and the reorganization of desmin and titin at the light-microscopical level in myocytes during early stages of rabbit cardiogenesis. 


\section{Materials and methods}

Tissue and embryo preparation for immunofluorescence assays.

Cardiac, skeletal and smooth muscle samples were obtained from euthanized adult New Zealand White rabbits. Tissue samples were washed in cold phosphate buffered saline (PBS: $137 \mathrm{mM} \mathrm{NaCl}$ (Merck, Darmstadt, FRG) $13 \mathrm{mM}$ $\mathrm{Na}_{2} \mathrm{HPO}_{4} \cdot 2 \mathrm{H}_{2} \mathrm{O}$ (Merck), $3 \mathrm{mM} \mathrm{KH} \mathrm{PO}_{4}$ (Merck) in demineralized water, $\mathrm{pH} 7.4$ ) to remove blood and then quickly frozen in liquid nitrogen. Sections were obtained after embedding the frozen tissue in OCT (Tissue Tec, Miles, Naperville, II. USA; $10.24 \%$ Polyvinyl Alcohol, $4.26 \%$ Polyethylene Glycol, $85.5 \%$ Nonreactive Ingredients/. Five micron thick cryosections were mounted onto clean glass slides and air-dried at room temperature $(\mathrm{r} T)$ before storage at $-20^{\circ} \mathrm{C}$.

Rabbit embryos were dissected from uteri at stages between 7 and 28 days post conceptionem (dpc) under Nembutal anaesthesia (Pentobarbital; $90 \mathrm{mg} / \mathrm{kg}$; intravenously). After embedding the embryos in gelatine capsules (Balzers Union, Liechtenstein) filled with OCT, they were quickly frozen in liquid nitrogen (lower half of the capsule first). These encapsuled embryos were then oriented for cryosectioning, the sections mounted onto clean glass slides and air dried at $r T$ before storage at $-80^{\circ} \mathrm{C}$.

\section{Indirect immunofluorescence assays.}

The $5 \mu \mathrm{m}$ thick sections of the adult rabbit tissues were treated with $0.5 \%$ Triton X-100 (BDH Chemicals Ltd, Poole, UK) in PBS for $5 \mathrm{~min}$ at room temperature [29], followed by washing in PBS. The sections were incubated with the primary antibody (see below) for $30 \mathrm{~min}$, washed three times in PBS (10 min each) followed by a 30 min incubation with a secondary, fluorescein isothiocyanate (FITC)-, tetramethylrhodamine isothiocyanate (TRITC)- or Texas red (TxRd)-conjugated Ig-subclass specific Goat-anti-Mouse antibody (Nordic Immunochemicals, Tilburg, the Netherlands or Southern Biotechnology Associates Inc., Birmingham, Alabama, USA). The sections were then washed in PBS, with three washing steps of 10 min each. Sections were mounted in Mowiol (Hoechst, Frankfurt, FRG) [24] and examined using a Zeiss microscope equipped with epifluorescence illumination optics.

Sections of embryos were thawed quickly at $\mathrm{rT}$, fixed with methanol (Merck) at $20^{\circ} \mathrm{C}$ for $6 \mathrm{~min}$, followed by an acetone (Merck) fixation at $-20^{\circ} \mathrm{C}$ for $0.5 \mathrm{~min}$. After air drying for $15 \mathrm{~min}$ and a PBS-wash for $5 \mathrm{~min}$, the sections were immuno stained using either the single- or the double-label procedure. Both procedures started with a 30 min incubation with one of the specific primary monoclonal antibodies, followed by a PBS-wash (three times; 5 min each), and a $30 \mathrm{~min}$ incubation with a FITC-, TRITC- or TXRd-conjugated Ig-specific anti-mouse antibody (Nordic Immunochemicals or Southern Biotechnology Associates Inc.) and again rinsing in PBS with three washing steps of $5 \mathrm{~min}$. In the double-label procedure these immunostaining steps were repeated with a second monoclonal 
antibody of an $1 \mathrm{~g}$-subclass that differed from the monoclonal antibody that was used in the first step. After the single- or double-labeling procedure the sections were placed in distilled water for 5 min, followed by post-fixation in methanol for $5 \mathrm{~min}$. The sections were air-dried and mounted in Mowiol. Slides were exarnined using a Zeiss Universal Microscope equipped with epi-illumination optics.

\section{Antibodies.}

The following antibodies were used in this study:

Dp 1\&2-2.15:

11-5F:

CAM5.2:

RD301:

DE-R-11 and DE-B-5:

9D10:

a mouse monoclonal antibody to desmoplakins I\&ll, obtained from Sanbio b.v., Uden, The Netherlands IIgG1, used in a 1:400 dilution) $[3,25]$.

a mouse monoclonal antibody to desmoplakins I\&ll, which was a kind gift from Dr. D.R. Garrod, Manchester, UK (IgG1, 1:100) [8,26].

a mouse monoclonal antibody to keratin 8 llgG2a, $1: 10)[30]$, purchased from Becton \& Dickinson, Etten Leur, The Netherlands.

a mouse monoclonal antibody to desmin (lgG2b, undiluted culture superinatant [ud]] $[27,28]$.

two mouse monoclonal antibodies to desmin (DAKO A/S, Glostrup, Denmark), labeling both striated (skeletal and cardiac) and smooth muscle cells (both IgG1, 1:10| [5].

a mouse monoclonal antibody to titin, reacting at the A-I junction in striated and cardiac muscle $[15,36]$.

The monoclonal antibody 9010 was obtained from the Developmental Studies Hybridoma Bank, maintained by the Department of Pharmacology and Molecular Sciences, Johns Hopkins University School of Medicine, Baltimore, Md., USA, and the Departement of Biology, University of lowa, lowa City, IA, USA, under contract NO1HD. 6 -2915 from the NICHD.

\section{Results}

Cross-reactivity of antibodies with adu/t rabbit tissues.

All antibodies used in this study stained adult rabbit myocardium sections in a fashion to be expected from their known staining patterns as described before. The mouse monoclonal antibodies DP1\&2-2.15 and 11-F5, specific for desmoplakins I \&. II, stain the intercalated disks but not the Z-lines of rabbit myocardial tissue. The staining pattern of both monoclonal antibodies is identical, therefore only Dp1\&2-2.15 stained sections are shown here. Z-lines and intercalated disks are stained by the anti-desmin antibodies RD301, DE-R-11 
and DE-B-5. Thus in double stained sections the desmoplakin signal overlaps with the desmin signal only in the intercalated disks. Adult rabbit myocardial tissue is negative for keratin 8 and 18 , but shows the pairs of titin-specific striations in the 9D10 stained sections.
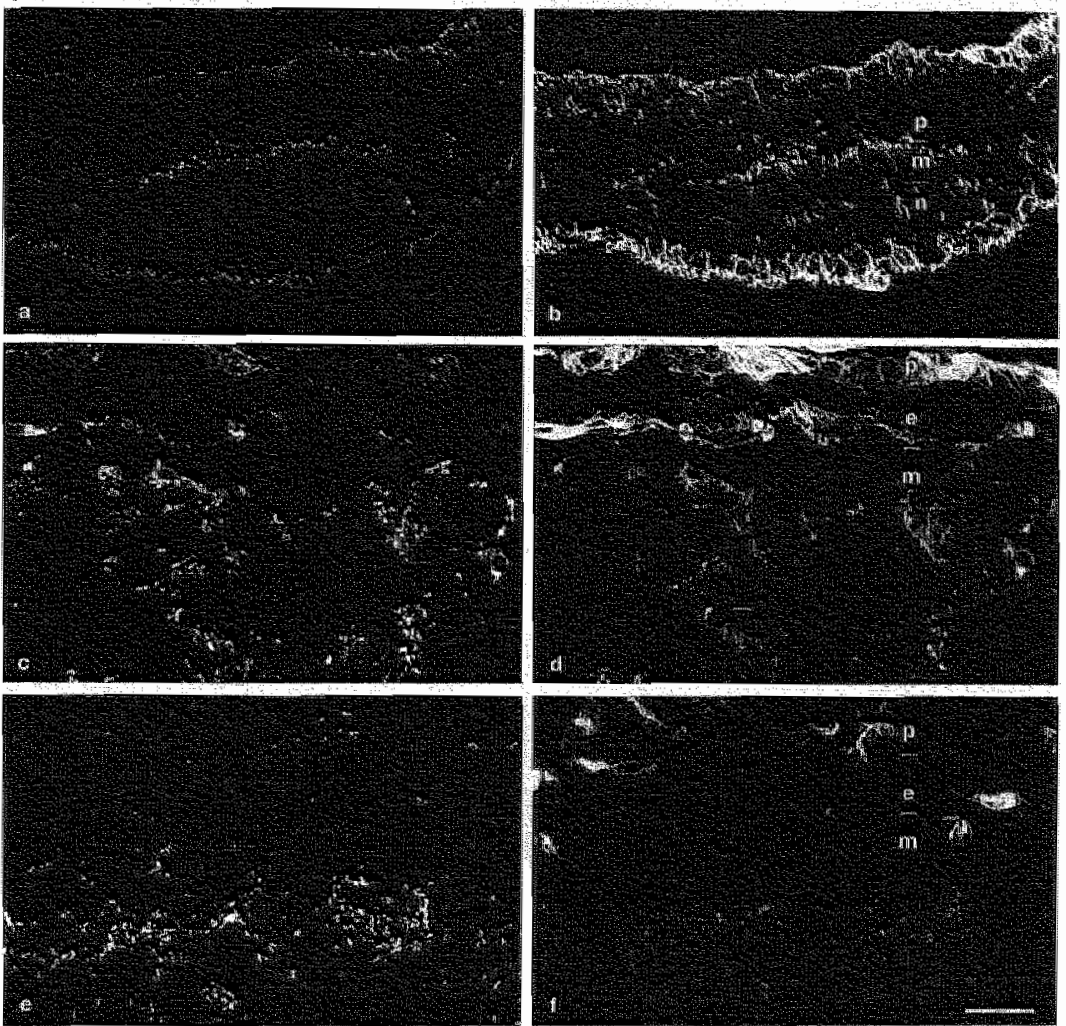

Fig. 5.1: Double labelied immunofluorescence micrographs of frozen sections from the heart region in $7.7(a, b), 10(c, d)$ and $13(e, f)$ dpc rabbit embryos. Micrographs $(a, c, e)$ show desmoplakin 1811 dots, double stained with keratin filaments or dots $(\mathbf{b}, \mathbf{d}, f) . P=$ Pericardium anlage, $M=$ Myocard anlage, $N=$ Endocardium anlage, $E=$ Epicardium anlage. Bar: $\mathbf{a}_{i} \mathbf{b} 14 \mu \mathrm{m}, \mathbf{c}-\mathbf{f} 6 \mu \mathrm{m}$.

Cardiogenic plates (0-1 somite pairs; $\leq 8.0 \mathrm{dpc}$.

In the rabbit, the first detectable heart anlagen are bilateral cardiogenic plates [14], identified by exclusive titin staining, in 0-1 somite embryos [34]. A striking observation in sections of this developmental stage is that desmoplakins are 

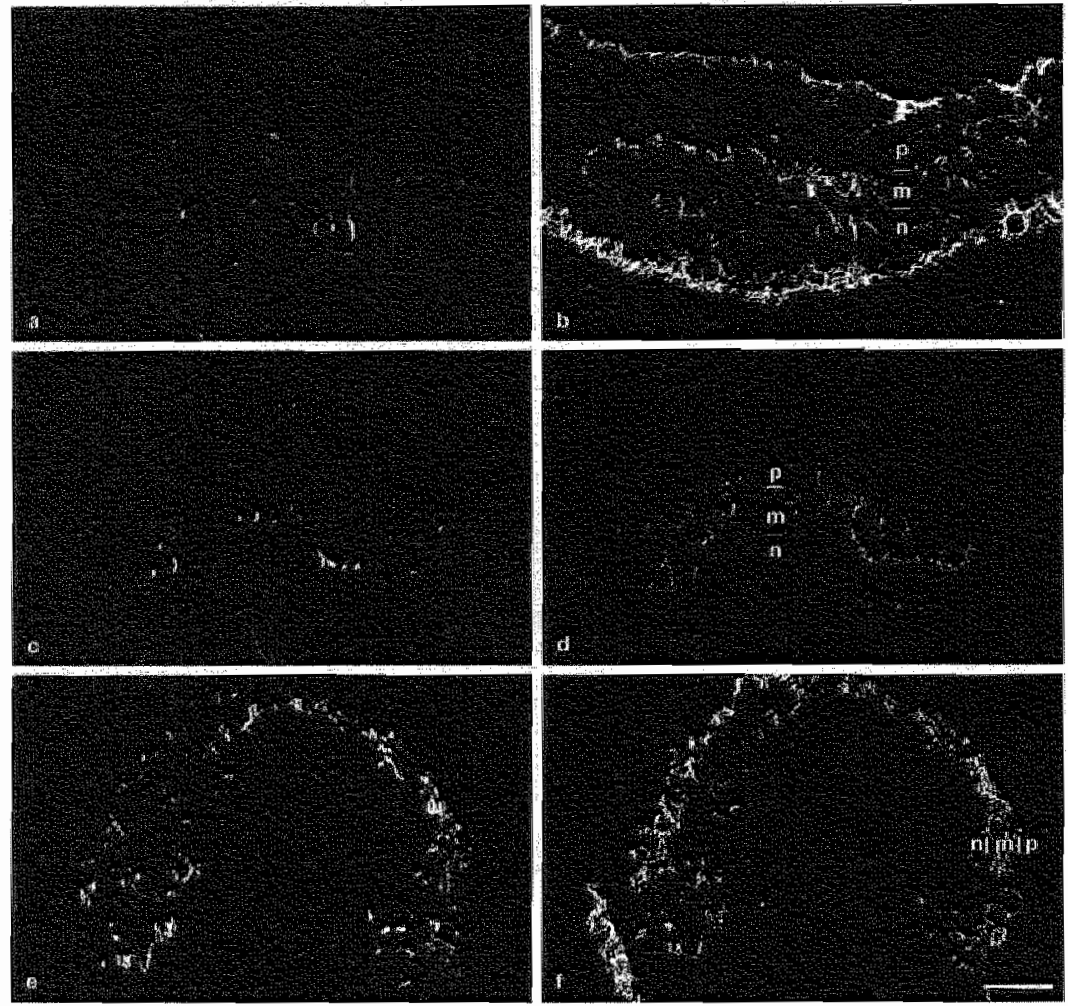

Fig. 5.2: Double labeled immunofluorescence micrographs of frozen sections from the heart anlage in $7.7(a, b), 8\left(c_{*} d\right)$ and $9(e, f)$ dpc rabbit embryos. Siections were stained for $(a, c, e)$ desmoplakins $\|\&\|$ and $(b, d, f)$ keratin. $P=$ Pericardium anlage, $M=$ Myocard anlage. $\mathbb{N}=$ Endocardium anlage. Bar: a d $14 \mu \mathrm{m}$, eff $10 \mu \mathrm{m}$.

more abundant in the early heart anlage as compared to the adjacent intra- and extraembryonic mesoderm (fig. 5.1a, 5.3a, 5.3c). The ectoderm and the endoderm are also positively stained with Dp2.15-182, but not as strong and as abundant as the heart anlage. The desmoplakins occur in dot-like aggregates in the embryonic cells. In the myocardium precursor cells of the coelomic epithelium, which are also the precursors for the epicardium, the majority of desmoplakin positive dots are apically located (fig. 5.1 a, 5.3a, 5.3c). In sections through the centre of the heart anlage (fig. $5.3 \mathrm{c}, \mathrm{d}$ ) desmoplakin dots are also found in the basal compartement of these precursor cells, where they colocalize 
with titin dots; in cells from the cranial or caudal periphery of the heart anlage (fig. $5.3 a, b$ ) both titin and basal desmoplakin expression are much reduced. Desmoplakin expression is present apically in the pericardium anlage (fig. 5.1a) but absent in the endocardium anlage. In these early stages of cardiogenesis. keratin is organized in filaments. Pericardium- and myoepicardium-precursor cells are strongly positive for keratin, mainly in the apical portion of the cells; towards the basement membrane the number of keratin positive filament bundles is lower (fig. 5.1b, 5.2b). At the light-microscopical level, the desmoplakin dots in the myocardium precursor cells colocalize with these keratin filaments (fig. 5.1a,b). Desmin (fig. $5.2 \mathrm{a}, \mathrm{c}$ ) is present in a filamentous organization, mainly located basally in the myocardium forming cells. There is no direct topological relation of desmin with desmoplakins or keratins.

Bitubular heart anlagen (2-10 somites; $8-9 \mathrm{dpc}$ ).

In the embryos of $8 \mathrm{dpc}$, titin dots were found basally and apically in the myocardium precursor cells (fig. 5.3f). Desmoplakin has increased at the basal side of the cells, where more dot-like aggregates are found as compared to the earlier stages (compare figs. $5.1 \mathrm{a}$ and $5.3 \mathrm{e}$ ). Desmin is still restricted mainly to the basal side of the cells (fig. 5.2e) and keratin is still organized in filaments (fig. 5.2f). A few hours after this stage, desmoplakin dots have expanded over the whole cell.

\section{Medially fused heart tubes (9-30 somites; $10.0 \mathrm{dpc}$.}

In $10 \mathrm{dpc}$ embryos (9-30 somite pairs), the bilateral tubular heart anlagen that were formed in 2-8 somite pair embryos $(8-9 \mathrm{dpc})$ approach and fuse medially. resulting in the formation of a single tubular heart. In the myocardium, desmoplakins are present in dot-like aggregates (fig. $5.1 \mathrm{c}$ ). Desmoplakin expression in the epicardium is dot-like and obviously restricted to intercellular junctions (fig. $5.1 \mathrm{c}$ ). At the light-microscopical level, keratin is mostly found organized in filaments but also in dots in the myocardium (fig. 5.1d). These keratin dots always colocalize with desmoplakins (fig. 5.1c,d). Both the epicardium and the pericardium are positive for keratin. In the myocardium, desmin is still expressed in filaments which are distributed all over the cytoplasm of the cells at this stage (not shown). Myocardial cells at this stage express titin mainly in a filamentous fashion, but cross-striated staining patterns are emerging (not shown). There does not seem to be an obvious colocalization at the lightmicroscopical level of desmoplakins with titin or desmin.

\section{Segmented heart / / $>30$ somites; 13-16 dpcl.}

After fusion of the bilaterally developed tubular heart anlagen, the atria and ventricles are formed, resulting in a segmented heart. In the myocardium of a 13 dpc rabbit embryo, the desmoplakin expression is abundant and shows a punctated staining pattern (fig. 5.1e). The keratin expression in the myocardium is decreased as compared to the earlier stages. Fewer positively stained keratin 
filaments and some dot-lke keratin aggregates are found (fig. 5. 1f). Desmoplakin positive spots are colocalized with keratins (fig. 5. 1e.f). The epicardium and the pericardium however are both keratin positive (fig. 5.1f), with a few desmoolakin positive dots at the intracellular junctions in these cell-lavers. The endocaralum is negative for keratin.
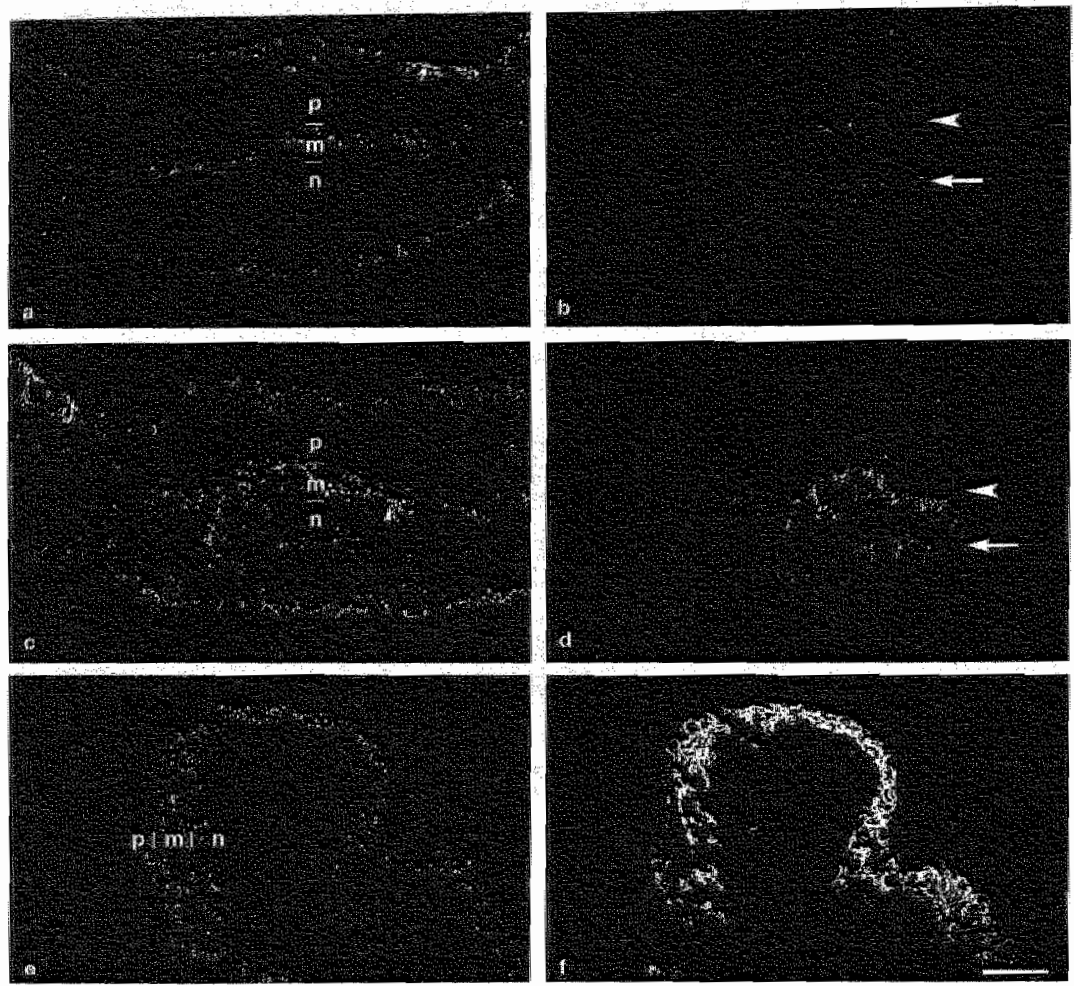

Fig. 5.3: Double labeled immunofluorescence micrographs af frozen sections from la-d) a 7.7 and $(e, f)$ a $8.9 \mathrm{dpc}$ rabbit embryo, stained for (a,c,e) desmoplakins 18 ll and (b.d, in titin. Arrowheads in (b) and (d) indicate the apical titin expression and arrows indicate the expression of titin in the basall compartement of the cells. $P=$ Pericardium anllage. $M=$ Myocardium anlage, $N=$ Endocardium anlage. Bar: a-d $14 \mu \mathrm{m}$, ef $12 \mu \mathrm{m}$.

At this stage, desmin reorganizes from a filamentous form into a striated pattern in the myocardium, while titin is organized completely in a cross-striated pattern (not shown) [34]. Both proteins organize into a laterally orientated pattern. 
Embryos at $16 \mathrm{dpc}$ (not shown) still express keratin filaments and aggregates in the myocardium, the epicardium and the pericardium. The endocardium remains keratin negative. Desmoplakin staining in the myocardium is abundant and organized in a punctated fashion. The desmoplakin expression in the epicardium is decreased. At this stage, desmin is present in a cross-striated fashion, as is titin [34].

Segmented heart $/ / 19 \mathrm{dpc}$.

In the myocardium of $19 \mathrm{dpc}$ embryos, both desmoplakins and keratins are organized in dot-like aggregates. Keratin expression in the myocard has decreased further as compared to earlier stages and is exclusively present in a weak punctated fashion (fig. 5.4b). Filamentous keratin expression in the myocard is lost. All remaining keratin clusters seem to colocalize at the lightmicroscopical level with the desmoplakin spots, that are abundant in the myocard anlagen (fig. 5.4a). The peri- and epicard are keratin positive (fig. 5.4b), while the endocard remains keratin negative. Desmin is already organized into its typical striated pattern, indicating Z-lines and intercalated disks (not shown). Titin is also present in a cross-striated pattern (arrow; fig. $5.4 \mathrm{c}$ ).

Segmented heart I/I (28 dpc embryos; not shown).

Keratin expression is completely lost in the myocard of $28 \mathrm{dpc}$ embryos, comparable to the situation in the myocard of an adult rabbit. Desmoplakin spots are present in the intercalated disks, where they colocalize with desmin. The latter protein is found both in the intercalated disks and in the Z-lines, which are negative for desmoplakins. Titin is organized in its specific cross-striated staining pattern.

\section{Discussion}

In our efforts to elucidate the role of cytoskeletal proteins in muscle cell differentiation [28,34] we have noticed that keratin intermediate filaments occur in early stages of myocardiogenesis. The myocard is derived from epithelial cells, therefore myocardial cells of some vertebrates are keratin positive in embryonic or fetal stages. In rabbit, keratin is not expressed in accordance with epitheliall or mesenchymal tissue organization. Rather, the expression of these proteins seems to be related to cellular function during embryonic development [35]. Franke and collaborators $[10]$ have described the presence of desmoplakins in the intercalated disks of cardiomyocytes, proteins known to interact with keratin filaments in adult epithelial cell types. In the intercalated disk of aduit cardiomyocytes, however, intermediate filaments of the desmin type have been identified, and not keratins. Taking together these earlier observations, we wondered if and how these different types of intermediate filaments and desmoplakins interact during heart muscle development. Therefore several 
developmental stages of the embryonic and fetal rabbit heart were examined for the expression and organization of these cytoskeletal and desmosomal constituents. Titin was included in this study because this protein can possibly function as a template for desmoplakin reorganization [34].
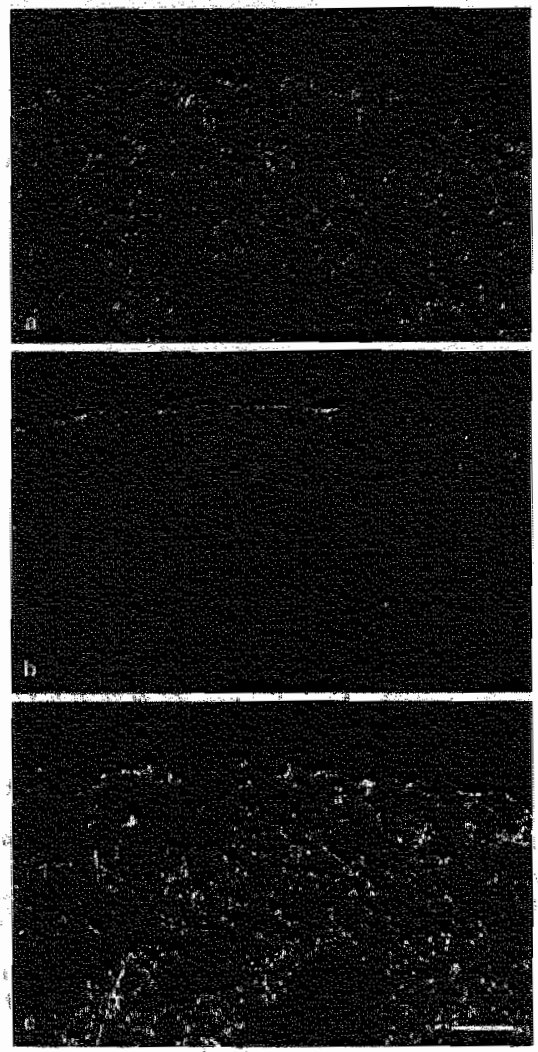

Fig. 5.4: Immunofluorescence micrographs of serial sections from a 19 dpc rabbit heart. Sections show myocardial expression of

(a) desmoplakins $1 \& 1 /$ (Dp 1\&2-2.15) and (c) titin (9D10), and (b) epicardial expression of keratin 8 (CAM5.2). Bar: $9 \mu \mathrm{m}$.

The reorganization of desmoplakins, keratins, desmin and titin during rabbit cardiogenesis.

The first stage where the myocardial precursor cells can be clearly and specifically identified by their titin staining reaction is at $7.7 \mathrm{dpc}$ [34]. In the myocardial precursor cells of the cardiogenic plates of these embryos desmoplakin is present in dot-like aggregates, located apically in the cells at first and with the onset of titin expression desmoplakins are beginning to be expressed basally as well. Desmoplakins are present therefore in the myocardium 
anlagen starting from the earliest identifiable stage of cardiogenesis. The majority of keratin filaments in these cells is located apically with some keratin positive filaments occuring basally, whereas desmin is present in the basal compartment only of these precursor cells. The keratin filaments include both keratin 8 and keratin 18 as demonstrated at the light-microcopical level [34] and the electron-microscopical level [19]. After fusion of the theart tubes $(10 \mathrm{dpc})$ desmin expression extends throughout the cytoplasm of the myocardium precursor cells. Simultaneously, the keratin filaments gradually disappear, remaining as dot-like aggregates, and the number and size of desmoplakin clusters increases while their intracellular distribution is still difficult to ascertain. In the segmented heart of $19 \mathrm{dpc}$ embryos, desmin is organized into a striated pattern, occuring in Z-lines and intercalated disks. At this stage, the remaining keratin aggregates are found laterally in the developing sarcomeres, colocalizing with the abundant desmoplakin clusters. Keratin filament bundles are not found anymore in the myocardium of these embryos. There is always a colocalization between desmoplakin dots and keratin positive spots. In $28 \mathrm{dpc}$ embryos keratin expression is not detectable in the myocardium, while desmoplakins are exclusively found in the intercalated disks, and desmin occurs in both the Z-lines and the intercalated disks. Apart from this apparent colocalization of desmin and desmoplakins in late fetal and adult myocardium, no obvious interactions of desmin and desmoplakins were found during cardiogenesis. No relation between the desmoplakin rearrangement and titin relocalization was found in the developing rabbit myocardium.

Down-regulation of keratin expression in the developing myocardium.

Studies on cardiogenesis of various vertebrate species $[19,34]$ indicate a loss of keratin filaments via dot-like aggregates. In the rabbit, this apparent condensation of keratin filaments into clusters starts before $10 \mathrm{dpc}$ and seems to be completed in $16 \mathrm{dpc}$ embryos. The number of keratin positive aggregates decreases fast in embryos of 16 to $19 \mathrm{dpc}$ and the myocardium becomes gradually keratin negative between 19 and 28 dpc. As previously shown [34], both keratin 8 and keratin 18 expression is lost. Just before keratin expression is lost, keratin chusters are located at the intercalated disks las determined by the colocalization with desmoplakins, see below). In rabbit myocardium keratin expression is lost before birth, but in chicken myocardium keratins are still present after hatching [19], stressing the variety in the process of cardiomyogenesis between various species.

\section{The relation of desmoplakins and keratins.}

In rabbit myocardium development, desmoplakin clusters are always colocated with keratins: in the early stages with the keratin filaments in the cytoplasm, in later stages with the dot-like aggregates until the expression of keratins is lost. Kuruic and Franke [19] demonstrated that keratins are associated with the desmosomal plaques of intercalated disks in certain fetal stages. Here we 
demonstrate the colocalization of cytoplasmic desmoplakins clusters with the collapsing keratin filaments which gradually retracted into dot-like aggregates. This might indicate a co-migration of these proteins during the proces of rabbit cardiogenesis: keratins might function as a guiding system for the cytoplasmically located desmoplakins towards the intercalated disks, in particular since keratin aggregates accumulate in these latter structures before they are lost.

\section{The relation of desmoplakins and desmin.}

Another aspect of the reorientation is the establishment of the intracellular arrangement of the myogenic protein desmin. Desmin is to a large extent specific for all muscle cells [7,20,33; for exeptions see 12,21] and shows differences in arganization related to the degree of muscle-development. Desmin is orglanized in filaments in cardiomyoblasts and connected with Z-lines and intercalated disks in adult cardiomyocytes $[6,23,28]$. In cardiomyocytes, intermediate filaments of the desmin type are attached to desmoplakin containing regions of the plasma membrane [18]. Our double staining experiments showed that in the early stages, desmin filaments are mainly located at the basal side of the myocardium precursor cells. Desmin expression expands from the basal side towards the apical side of the cells in the next developmental stages and is subsequently organized into a cross-striated pattern. The desmin filaments expand parallel to the direction of contraction of the mature sarcomeres, suggesting that the change in polarity of the myocardium cells parrallels the desmin reorganization. The overlap in desmoplakin plaques and desmin filaments in early stages is a likely proposition but could not be demonstrated as the antibodies used for these proteins were of the same subclass and not suitable for double staining, or, in case of the mouse monoclonal RD301, gave a staining that was very weak in the early stages of devellopment and could not elucidate the proposed colocalization. Therefore itt could not be clarified whether the rearrangement of desmoplakins from a cytoplasmic into an intercalated disk localization is guided or induced by the desmin reorganization. The use of immuno-electron microscopy may provide insight in the possible interactions of desmoplakins and desmin at the molecular level, and may elucidate the relation of these proteins during cardiogenesis.

\section{The role of titin in desmoplakin reorganization.}

Titin is the first striated muscle specific protein to be expressed in the embryonic rabbit heart [34]. Titin first appears as dot-like aggregates in skeletal or cardiac myoblasts of rabbit, mouse or chicken $[13,28,31,32,34]$, but during differentiation gradually becomes organized into a cross-striated pattern with periodic arrays via a fillamentous organization. Increasing basal desmoplakin expression seems to follow the increase in titin expression closely. In early stages both titin and desmoplakins occur as clusters. Although some aggregates of these proteins colocalize at first, desmoplakins do not colocalize with titin 
filaments or the cross-striated pattern in later stages of development "and there does not seem to be a general topographical relation between titin and desmoplakins. However, at the earliest stages of cardiogenesis expression of desmoplakins in the basal compartment seems to follow immediately the onset of titin expression, which suggests a close temporal relationship between titin expression and desmoplakins reorganization. Whether this temporal relationship is coincidal or is related may be elucidated by the use of titin antibodies directed against other epitopes, and by experiments at the sub-light microscopical level. The possibility that the titin reorganization and the desmoplakin expression are two independent processes that happen to occur at the same time during development can not be excluded yet.

\section{Concluding remarks.}

The general conclusion that can be drawn from this study is that the first sign of reorientation in myocardium precursor cells is basal expression of desmoplakins, possibly induced by increasing titin expression. The expression and reorganization of keratin in myocardium precursor cells may then have a function in the reorganization of desmoplakins into the intercalated disks. The reorganization from apical to basal oriented myocardium precursor cells into laterally orientated myocardium cells, is finally established by strong lateral attachment sites: the intercalated disks. Although desmin is also a dominant protein in the intercalated disks, a clear relation of desmin reorganization and desmoplakin relocalization could not be proven with the methods used.

Acknowledgements.

Part of this work was supported by the Netherlands Heart Foundation and the Deutsche Forchungs Gemeinschaft (Wa 359-9).

\section{References}

1. Arnn, J., J.A. Staehlin: The structure and function of spot desmosomes. Int. J. Dermatol. 20, 330-339(1981).

2. Buxton, R.S., P. Cawin. W.W. Franke, D.R. Garrod, K.J. Green, I.A. King, P.J. Koch, A.I. Magee, D.A. Rees, J.R. Stanley, M.S. Steinberg: Nomencllature of the desmosomal cadherins. J. Cell Biol. 121, 481-483 (1993).

3. Cowin, P., H.P. Kapprell, W.W. Franke: The complement of demosomal plaque proteins in different cell types. J. Cell Biol. 101, 1442-1454 (1985).

4. Danto, B.I., D.A. Fischman: immunocytochemical analysis of intermediate filaments in embryonic heart cells with monoclonals to desmin. J. Cell Bioll. 98. 2179-2191 (1984).

5. Debus, E., K. Weber, M. Osborn: Monoclonal antibodies to desmin, the musclespecific intermediate filament. EMBO J. 2. 2305-2312(1983). 
6. Fischman, D.A., S.l. Danto: Monoclonal antibodies to desmin: Evidence for staga-dependent intermediate fllament immunoreactivity during cardiac and skeletal muscle development. Ann. N.Y. Acad. Sci. 455, 167-184(1985).

7. Fischman, D.A.: Myofibrillogenesis and the morfogenesis of skeletal muscle. In: A.G. Engel, B.O. Banker (eds.): Myology: Basic and Clinical. pp. 5- 30. McGrawHill, New York 1986.

8. Flemming, T.P., D.R. Gerrod, A.J. Elsmore: Desmosome biogenesis in the mouse premplantation embryo. Development 112, 527.539(1991).

9. Franke, W.W. C. Grund, C. Kuhn, B.W. Jackson, K. Illmensee: Formation of cytoskeletal elements during mouse embryogenesis. II. Primary mesenchymal cells and the first appearance of vimentin filaments. Differentiation $23,43-59$ $(1982 a)$.

10. Franke, W.W., R. Moll, D.L. Schiller, E. Schmid, J. Kartenbeck, H. Müller: Desmoplakins of epithelial and myocardial desmosomes are immunologically and biochemically related. Differentiation $23,115-127(1982 b)$.

11. Franke, W.W., R. Moll, H. Müller, E. Schmid, C. Kuhn, F. Krepler, U. Artlieb, H. Denk: Immunocytochemical identification of epithelium-derived human tumors with antibodies to desmosomal plaque proteins. Proc. Natl. Acad. Sci. USA 80, 543-547(1983).

12. Franke, W.W., R. Moll: Cytoskeletal components of lymphoid organs. I. Synthesis of cytokeratins 8 and 18 and desmin in subpopulations af extrafollicular reticulum cells of human 1 mmph nodes, tonsils and spleens. Differentiation 36, 145-163(1987).

13. Fürst, D.O., M. Osborn, K. Weber: Myogenesis in the mouse embryo: differential onset of expression of myogenic proteins and the involvement of titin in myofibril assembly. J. Cell Biol. 109, $517.527(1989)$.

14. Girgis, A.: The development of the heart of the rabbit. Proc. Zool. Soc. 49, 755$782(1930)$.

15. Greaser, M.L., S.E. Handel, S.-M. Wang, E. Schulz, J.C. Bulinski, J.L. Lessard: Assembly of titin, myasin, actin and tropomyosin into myofibrils in cultured chicken cardiomyocytes. In: F. Stockdale, L. Kedes (eds.): Cellular and mollecullar biology of muscle development. UCLA Symposium on molecular and cellular biology of muscle develapment. New Series Vol. 93, pp. 246-257. Liss. New York 1989.

16. Jackson, B.W., C. Grund, E. Schmid, K. Bürki, W.W. Franke, K. Illmensee: Formation of cytoskeletal elements during mouse embryogenesis. Intermediate filaments of the cytokeratin type and desmosomes in preimplantation embryos. Differentiation 17, 161-179 (1980).

17. Jackson, B.W., C. Grund, S. Winter, W.W. Franke, K. Illmensee: Formation of cytoskeletal olements during mouse umbryogenesis. II. Epithelial differentiation and intermediate-sized filaments in early post-implantation embryos. Differentiation 20, 203-216 (1981).

18. Kartenbeck, J., W.W. Franke, J.G. Moser, U. Stoffels: Specific attachment of desmin filaments to desmosomal plaques in cardiac myocytes. EMBO J. 2, 735$742(1983)$.

19. Kuruc, K., W.W. Franke: Transient coexpression of desmin and cytokeratins 8 and 18 in developing myocardial cells of some vertebrate species. Differentiation $38,177-193(1988$ ).

20. Lazarides. E., B.D. Hubbard: Immunological characterization of the $100 \AA$ filaments from muscle. Proc. Natl. Acad. Sci. USA 76, 4344-4348(1976).

21. Molengraft, F. van de, F.C.S. Ramaekers, P. Jap, P. Vooijs, G. Mungyer: Changing intermediate-filament patterns in metastatic hepatocellular carcinoma cells of the guinea pig. Virchows Arch. B 51, 285-301 (1986). 
22. Muller, H. W.W. Franke: Biochemical and immunological characterization of desmoplakins 1 and 11 , the major polypeptides of the desmosomal plaque. J. Mol. Biol. 163,647-67》(1983).

23. Osinska, H.E., L.F. Lemanski: Immunofluorescent location of desmin and vimentin in developing cardiac muscle of the Syrian hamster. Anat. Rec. 223. 406-413 (1989).

24. Osborn, M. K. Weber: Immunofluorescence and inmunocytochemical procedure with affinity purified antibodies: tubulin containing structures. Methods Cell Biol. 24. $97-132(1982)$.

25. Owaribe, K.. Y. Nishizawa, W.W. Franke: Isolation and characterization of hemidesmosomes from bovine corneal epithelial cells. Exp. Cell Res. 192, 622-630 (1991).

26. Parrish, E.P., P.V. Steart, D.R. Garrod, R. Weller: Antidesmosomal monocllonal antibody in the diagnosis of intracranial tumours. J. Pathol. 153, 265-273 (1987).

27. Pieper, F.R., G. Schaart, P.J. Krimpenfort, J.B. Henderik, H.J. Moshage, "C.S. Ramaekers, A. Berns, H. Bloemendal: Transgenic expression of the musclespecific intermediate fillament protein desmin in non-muscle cells. J. Cell Biol. 108, 1009-1024(1989).

28. Schaart, G., C. Viebahn, W. Langmann, F.C.S. Ramaekers: Desmin and titin expression in early postimplantation mouse embryos. Development $107,585.596$ $(1989)$.

29. Schaart, G., F.R. Pleper, H.J.H. Kulipers, H. Bloemendal, F.C.S. Ramaekers: Baby hamster kidney (BHK-21/C13) cells can express striated muscle type proteins. Differentiation 46:105-115 (1991).

30. Smedts, F., F. Ramaekers, H. Robben, M. Pruszozynski, G. van Muijen, B. Lane, 1. Leigh, P. Vooijs: Changing patterns of keratin expression during progression of cervical intraepithelial neoplasia. Am.J.Pathol. 136, 657-668 (1990).

31. Tokuyasu, K.T., P.A. Maher: Immunocytochemical studies of cardiac myofibrillogenesis in early chick embryos. I. Presence of immunofluorescent titin spots in premyafibril stages. J. Cell Biol. 105. 2781-2793 (1987a).

32. Tokuyasu, K.T., P.A. Maher: Immunocytochemical studies in early chick embryos. II. Generation of $\alpha$-actinin dots within titin spots at the time of the first myofibril formation. J. Cell Biol. $105,2795-2801(1987 \mathrm{~b})$.

33. Traub, P. Intermediate filaments. A review, pp. 2-17. Springer-Verlag, Berlin/ Heidelberg/ New York/ Tokyo 1985.

34. Van der Loop. F.T.L., G. Schaart, W. Langmann, F.C.S. Ramaekers, Ch. Viabahn: Expression and organization of muscle specific proteins during the early developmental stages of the rabbit heart. Anat. Embrol. 185, 439-450 (1992).

35. Viebahn, Ch., E.B. Lane, F.C.S. Ramaekers: Keratin and vimentin expression in early organogenesis of the rabbit mbryo. Cell Tissue Res. $253,553-562(1988)$.

36. Wang. S.-M., M.L. Greaser: Immunocytochemical studies using a monoclonal antibody to bovine cardiac titin on intact and extracted myofibrils. J Muscle Res Cell Motil 6. 293-312(1985). 



\section{6}

\section{Smoothelin, a novel cytoskeletal protein specific for smooth muscle cells.}

Frank T.L. van der Loop, Gert Schaart, Erika D.J. Timmer, Frans C.S. Ramaekers and Guillaume J.J.M. van Eys.

Journal of Cell Biology: manuscript based on this chapter submitted for publication.

In smooth muscle cells a novel cytoskeletal protein was detected and characterized. The $59 \mathrm{kDa}$ protein has been designated "smoothelin" since immunohistochemical analyses and Northern blotting of a variety of tissues showed that this protein is solely found in smooth muscle cells. A human smooth muscle cDNA library was screened with the monoclonal antibody, and a full size cDNA of the protein was selected. The cDNA was sequenced and demonstrated to contain a 1113 bp open reading frame. Computer assisted analysis at the protein level revealed a 56 amino acid domain with homologies of about $40 \%$ with a sequence bordering the actin binding domains of dystrophin, utrophin, beta-spectrin and alpha-actinin. In situ hybridization demonstrated that human smoothelin is encoded by a single copy gene which is located on chromosome 22. Immunohistochemistry and Western blotting revealed expression of smoothelin in smooth muscle of species evolutionary as far apart as human and Xenopus leavis. Northern blotting indicated that sequence as well as size of the mRNA (about 1500 bases) are conserved amongst vertebrates. Cell fractionation studies and differential centrifugation showed that the protein cannot be extracted with Triton-X100, indicating a cytoskeletal function. Tramsfection of the human CDNA into COS7 cells produced a protein of $59 \mathrm{kDa}$, which assembled into a filamentous network. Smoothelin was not detected in primary and long term smooth muscle cell cultures, and its transcription was almost instanty halted if smooth muscle was brought into tissule culture. Wo conclude that smoothelin is a new cytoskeletal protein that is only found in contractile smooth muscle cells and does not belong to one of the classes of structural proteins presently known. 


\section{Introduction}

Smooth muscle cells are of mesodermal origin and are present in the wall of almost the entire gastrointestinal tract, essential parts of the cardiovascular system, the respiratory system, the urinary tract and in the reproductive system. In spite of the presence of smooth muscle cells in all these tissues, differentiation and cell biology of these cells is poorly documented in comparison to that of striated muscle cells. While an increasing number of proteins involved in the contraction of striated muscle cells has been described, only a limited number of such constituents has been identified for smooth muscle cells (North, 1994). Nevertheless, it is to be expected that the complexity of the contractile apparatus of striated cells has to be matched by a comparable organization in smooth muscle cells. Also, the process of smooth muscle cell differentiation is still poorly understood, partly because of the lack of differentiation markers, partly because of differences between smooth muscle cells in different organs. Smooth muscle cells can be considered as a heterogeneous collection af cells with similar (but not identicall) physiological properties. For instance, it has been suggested that smooth muscle cells surrounding blood vessels may be recruted from surrounding tissues during embryogenesis (Gabbiani et al., 1981; Nanaev et al., 1991; Bochaton-Palliat et al., 1994). Differences in size, function and biochemistry between smooth cells muscle in different organs have been observed and may reflect differences in origin (Sartore et al., 1989; Haeberle et al., 1992; Frid et al., 1992; Ehler et al., 1995). It is widely accepted that smooth muscle celis can shift from the proliferative, synthetic to the contractile phenotype and the other way around but understanding of these phenotypic changes is limited (Skalli et al., 1986; Campbell et al., 1989; Pauletto et al., 1994). Availability of specific markers will improve the understanding of the proliferation and differentiation of smooth muscle cells.

A number of proteins has been described to occur mainly in smooth muscle cells i.e. smooth muscle myosin, alpha-smooth muscle actin, metavinculin, calponin and h-caldesmon (Lees-Miller et al., 1987; Takahashi et al., 1988; Nagal et al., 1989; Takahashi and Nadal-Ginard, 1991; Frid et al , 1992). However, none of these phenotypic markers is truly specific for smooth muscle cells. $a$-Smooth muscle actin expression is also found in developing striated muscle cells and in pathologic cardiac muscle (Babai et al., 1990; McHugh et al., 1991, Ausma et all., 1995). Other marker proteins, such as calponin, metavinculin and isoforms of myosin, have also been found in pericytes, platelets and endothelial cells (Turner and Burridge, 1989; Borrione et al., 1990; Takeuchi et al., 1991). Contractile, cytoskeletal and cytoskeleton-associated proteins have been described as differentiation markers for smooth muscle cells but their value as such is not well defined (Glukhova et al. 1986; Takahashi et al., 1988; Malmqvist and Arner, 1990; Uetsuki et al., 1990; Duband et al., 1993). Expression of most of these marker proteins is observed in rather early stages of differentiation and sofar no marker for late differentiation stages of smooth 
muscle cells has been described. Also, there is no marker available to distinguish decisively between proliferative and contractile smooth muscle cells.

Here we describe the cloning of a cDNA coding for a smooth muscle specific protein. which has been designated smoothelin. The protein is expressed in cells of all smooth muscle tissues investigated but only when these cells are fully differentiated and apparently contractile. Smoothelin forms a filamentous network but has no major homologies with one of the known families of structural proteins.

\section{Materials and methods}

Tissue samples.

Normal adult human tissues, obtained by autopsy, and tissues from a variety of animals (pig, dog, cattle, rabbit, rat, mouse, Xenopus laevis) were immediately frozen in liquid nitrogen and stored at $-80^{\circ} \mathrm{C}$ until use. Vascular smooth muscle cells were obtained from bovine aorta, human uterine and mammary artery by collagenase/pancreatine digestions. Cells were cultured in Dulbecco's Modified Essential Medium supplemented with $15 \%$ fetal calf serum (Life Technologies, Gaithesburg, Md, USA). Smooth cells cultured for at least 5 passages are considered to be "long term cultures". Myoma tissue explants were obtained by slicing the myoma tissue in slices of about $1 \mathrm{~mm}$. These slices were incubated as described for the cell cultures.

For immunohistochemistry tissues were mounted in Tissue-Tek (OCT-compound; Miles Inc. Elkhart, In, USA), and 3 to $5 \mu \mathrm{m}$ thick sections were cut at $-25^{\circ} \mathrm{C}$ and air-dried overnight at room temperature or immediately fixed with methanol ($20^{\circ} \mathrm{C}$ for $\left.5 \mathrm{~min}\right)$ followed by acetone $\left(-20^{\circ} \mathrm{C}\right.$ for $30 \mathrm{sec}$ and air-dried for 3 hours before use.

Cells were grown on cover slips and also fixed in methanol/acetone.

\section{Antibodies.}

Antibodies used in this study were:

1. The mouse monoclonal antibody R4A directed against smoothelin. To generate the antibody mice were immunized with a high salt/Triton- $\times 100$ extracted preparation of chicken gizzard. Fusion procedure and cloning of the hybridomas were performed according to standard protocols (Köhler et al., 1975:. The monoclonal antibody R4A was selected on basis of its specific reactivity pattern with smooth muscle cells. R4A is an antibody of the IgG1-subclass (Mouse Mab Isotyping kit; Life Technologies, Gaithesburg, USA).

2. Monoclonal antibody E7 to beta-tubulin (Chu et al., 1987).

3. Polyclonal rabbit antiserum ( $\mathrm{pDes}$ ) to chicken gizzard desmin (Ramaekers et al., 1985).

4. Affinity-purified polyclonal rabbit antibody ( $\mathrm{pVim}$ ) raised against bovine lens 
vimentin (Ramaekers et al., 1983).

5. Monoclonal antibody RO301 to desmin (Schaart et al., 1991).

6. Affinity-purified polyclonal rabbit antibody (pKen) raised against human skin keratins (Ramaekers et al., 1983).

7. Monoclonal antibody sm-1 to smooth muscle actin was purchased from Sigma Immuno Chemicals (St. Louis, MO, USA ISkalli et al., 1986).

In addition, rhodamine phalloidine (purchased from Molecular Probes Inc., Eugene, OR, USAl was used to stain F-actin stress-fibers.

\section{Immunohistochemistry.}

For the characterization of antibody R4A, immunofluorescence as well as immunoperoxidase staining has been performed on a variety of tissues of different species. In all cases 3 to $5 \mu \mathrm{m}$ thick cryostat sections were used. The sections were pretreated for 5 min with $0.5 \%$ Triton $X-100$ (BDH Chemicals Ltd., Poole, UK) in phosphate buffered saline (PBS: $137 \mathrm{mM} \mathrm{NaCl}, 13 \mathrm{mM}$ $\mathrm{Na}_{2} \mathrm{HPO}_{4}, 2 \mathrm{H}_{2} \mathrm{O}, 3 \mathrm{mM} \mathrm{KH} \mathrm{PO}_{4} \mathrm{pH}$ 7.4; Merck, Darmstadt, Germany), followed by a PBS washing step for $5 \mathrm{~min}$. Methanol/acetone fixed sections were used without Triton $X-100$-pretreatment.

Tissue sections were incubated with the primary antibody for $30 \mathrm{~min}$ at room temperature, washed with PBS and incubated with a secondary antibody conjugated to either fluorescein isothiocyanate (FITC) lgoat anti-mouse-lgG-FITC, Southern Biotechnology Associates Inc., Birmingham, Alabama, USA), or Texas Red (TR) (goat anti-rabbit-Ig-TR/goat anti-mouse-IgG1-TR; SBA), or horseradish peroxidase (peroxidase-conjugated rabbit anti-mouse; DAKO A/S, Copenhagen, Denmark\}. The secondary antibodies were applied for $30 \mathrm{~min}$ at room temperature. Peroxidase activity was detected with 4-amino-9-ethylcarbazole (AEC; Aldrich Chemical Company, St. Louis, MO, USA) as described previously (Schaart et al. 1991). After three washing steps with PBS, the stained tissues were mounted in Mowiol (Hoechst, Frankfurt, FRG) or in Kaisers glycerin-gelatin (Merckl) for AEC stained sections.

Protein gel electrophoresis and Western blotting.

Cultured cells (approximately $\left.10^{6}\right)$ or about 40 cryostat sections $(20 \mu \mathrm{m}$ thick) of fresh frozen tissues were collected, washed with $1 \mathrm{ml}$ PBS and centrifuged for 5 min at $12.000 \times g$. After centrifugation the pellet was subjected to a Triton $X$ 100 extraction step: after the PBS wash the pellet was suspended in $1 \%$ Triton $X-100,5 \mathrm{mM}$ ethylenediaminotetraacetic acid disodium salt dihydrate (EDTA; Merck), 0.4 mM phenylmethylsulfonyl fluoride (PMSF; Merck) in PBS, pH 7.4 (Schaart et al., 1991), and extracted for $5 \mathrm{~min}$ on ice. After centrifugation for 5 min at $12.000 \mathrm{xg}$, the pellet was washed in $1 \mathrm{ml}$ PBS. After a final centrifugation step ( $5 \mathrm{~min}, 12.000 \times \mathrm{g}$ ), the cytoskeletal preparation was dissolved by boiling for 4 min in SDS-sample buffer (Laemmli, 1970), containing $2.3 \%$ sodium dodecylsulfate (SDS) and 5\% B-mercaptoethanol (Bio-Rad Laboratories, Richmond, CA, USA). 
For one-dimensional SDS-polyacrylamide gel electrophoresis (SDS-PAGE) using a Mini Protean II Electrophoresis Cell (Bio-Rad Laboratories, Richmond, CA, USA) $7.5-10 \%$ polyacrylamide slab gels containing $0.1 \%$ SDS (Laemmi, 1970 ) were used. Two-dimensional, non-equilibrium, gel electrophoresis was performed according to O'Farrell (1975). After electrophoretic separation, the proteins were stained with Page Blue 83 (BDH Chemicals Ltd.) or subjected to Western blotting as described elsewhere (Schaart et al., 1991). Culture supernatant of monoclonal antibody R4A directed against smoothelin was used in a 1:5 dilution and immunodetection with horse-radish peroxidase conjugated rabbit anti-mouseIg (DAKO A/S) was performed according to standard procedures (Schart et all. 1991 .

Fractionation of smooth muscle tissues by differential centrifugation.

All steps of the procedure described below were performed on ice and for centrifugation a Beckman $T-60$ rotor was used. Frozen tissue blocks of intestinal smooth muscle tissue $(5 \mathrm{~g}$ human colon) were minced and homogenized in $15 \mathrm{ml}$ SET buffer $18.5 \%$ sucrose, $5 \mathrm{mM}$ Tris- $\mathrm{HCl} \mathrm{pH} 7.4,2 \mathrm{mM}$ EDTAl by a motor driven serrated teflon pestle at 1000 r.p.m. (Braun Potter-S). Homogenates were passed through SET-soaked cheese-cloth and pelleted at $1000 \times \mathrm{g}$. Supernatants of the subsequent steps were centrifuged at $9000,20,000$, and $110,000 \times \mathrm{g}$ for 10,15 and 60 min respectively. Samples of the pellets (resuspended in SET buffer without EDTA) and the supernatants of different fractions were subjected to SDS-PAGE followed by Western blotting, as described above.

Construction and screening of a human smooth muscle expression cDNA library. An expression cDNA library was constructed with human colon smooth muscle derived poly-A ${ }^{+}$RNA using the Lambda ZAP-CDNA synthesis kit (Stratagene, La Jolla, California, USA). Total RNA was extracted from human colon smooth muscle by $\mathrm{LiCl}$ extraction (Auffray and Rougeon, 1980). Poly-A*RNA was purified by oligo(dT)-cellulose chromatography (Aviv and Leder, 1972). Synthesis of cDNA (by oligo(dT) priming) and packaging were performed as suggested by the manufacturer. After packaging the Uni-ZAP XR vector in phage (Gigapack II Packaging extract, Stratagene), clones containing cDNA inserts between 600 and 1600 bp were selected by immuno-screening with antibody R4A. Inserts were subcloned and subjected to restriction analysis and sequencing after helper phage induced excision of plasmid vector pBluescript II pKS(-) (Stratagene). Sequencing was performed according to Sanger et al. (1975) using a T7 sequencing kit (Pharmacia, Upsalla, Swedenl. Searches for sequence homology were performed through the CAOS/EMBL data base (release 1995). Sequence comparison and structural analysis of the putative protein were performed on a UNIX computer using BLAST, BLAST-X algorithms (Altshul et al., 1990) and protein structure program PHD (Rost and Sander, 1993, 1994).

To check whether the 1554 bp clone contained a full size cDNA, total RNA of human colon smooth muscle tissue was subjected to rapid amplification of cDNA 
ends (RACE) (5'RACE-kit, Life Technologies, Gatherburg, Md, USA). The RACE products were amplified using Pwo polymerase (Boehringer Mannheim, Germanyl, cloned into pUC19 and sequenced as described above.

Northern blot analysis.

Total RNA of various tissues and from a variety of vertebrates (human, bovine, dog, rat, mousel was extracted by $\mathrm{LiCl}$ as described previously (Auffray and Rougeon, 1980). $10 \mu \mathrm{g}$ of total RNA was separated on a $2 \%$ agarose formaldehyde denaturing gel (Sambrook et al., 1989). RNA was transferred to nitrocellulose (S\&S, Basel, Switserland) and hybridized to the smoothelin-cDNA probe according to standard procedures (Church and Gilbert, 1984). Filters were washed in decreasing SSC $(\mathrm{NaCl}$, Na-citrate) concentrations with a finall concentration of $0.1 \times$ SSC $10.1 \%$ SDS. Probes were ${ }^{32} \mathrm{P}$ labeled by random priming using a kit with a DNA polymerase Klenow fragment (Life Sciences, Gaithesburg) according to Feinberg and Vogelstein (1983)..

\section{Transfection of smoothelin CDNA in COS7 cells.}

The full size smoothellin cDNA was recloned in a pcDNA3 eukaryotic expression vector (Invitrogen, San Diego, USA)[this construct is futher referred to as pCDNA3-SMO]. Isolated plasmid was purified by $\mathrm{CsCl}$ gradient centrifugation (Sambrook et al., 1989). Transfection of exponentially growing COS7 cells was done with $5 \mu \mathrm{g}$ purified DNA using the DOTAP lipocarrier system as suggested by the manifacturer (Boeringer Mannheim, Germany). After 16 and $40 \mathrm{~h}$ transfected cells were fixed with methanol/acetone or harvested after trypsinization. Fixed cells were incubated with rhadamine phalloidine and antibodies directed against smoothelin, vimentin, keratin and tubulin as described above. Harvested cells were collected by centrifugation and prepared for Western blotting analysis as described above.

\section{Production of smoothelin protein in E.coli.}

The smoothelin cDNA $(1600$ bp clone) was excised from Bluescript II and inserted into the prokaryote expression vectors pOE9/10/11 /Quiagen, Kassel, Germanyt. Insertion in these vectors results in a fusion of the cDNA encoded protein to a 6 -His peptide, allowing a single-step purification of the protein by binding to Ni-agarose. Protein were synthesized during overnight induction with 1 uM IPTG (Life Technologies, Gaithesburg, Md, USA). Proteins produced in E.coli were obtained by guanidine/urea extraction and purified according to the protocol of the manufacturer. After separation by SDS-PAGE proteins were blotted onto nitrocellulose and identified by antibody R4A as described above.

In situ hybridization.

Double target in situ hybridization on human metaphase preparations was performed as previously described (Voorter et al., 1995) combining a digoxigenin labeled chromosome 22 centromeric probe with the biotin labeled smoothelin 
cDNA probe. The applied concentration of both probes was $10 \mathrm{ng} / \mathrm{\mu l}$ hybridization mix. Hybrization and subsequent washes were performed according to standard procedures. The biotinylated probe was detected by FITC-conjugated avidin, and the digoxigenin labeled probe by tetramethyl rhodamin isothiocyanate (TRITC), using an anti-digoxigenin monoclonal antibody in combination with TRITC-conjugated rabbit-anti-mouse and swine-anti-rabbit antisera (DAKO A/S, Copenhagen, Denmark).

\section{Results}

Generation and characterization of antibodv R4A.

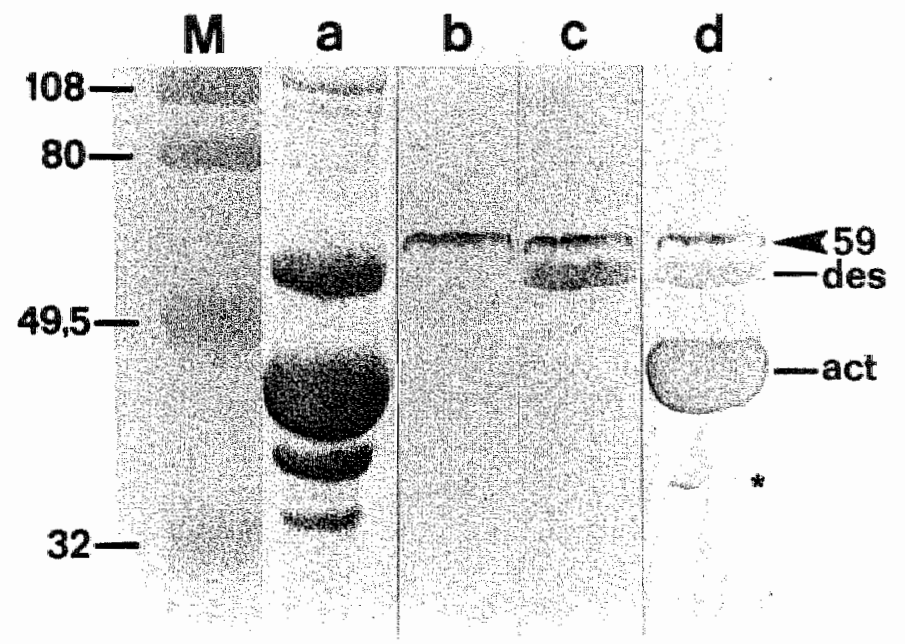

Fig. 6.1: Western blot showing the immunoreaction of a human colon smooth muscle preparation after subsequent incubations of the same blot with monoclonal antibodies R4A (lane b), anti-desmin RD301 (lane c) and anti-smooth muscle actin sm.1 (lane d). Lane a shows the Coomassie brilliant blue staining of the preparation. Marker lane is indicated by $M$. Asterisk indicates a degradation product of actin.

Balb/C mice were immunized with a chicken gizzard extract and hybridomas were produced. Antibody production was screened by immunofluorescence assays and by Western blotting on a variety of tissues. In immunofluorescence assays on sections of several tissues hybridoma clone R4A, producing an IgG1 type antibody, reacted exclusively with smooth muscle cells. Western blotting of one- and two-dimensional gels confirmed the microscopical observations. The 
immunoreactive protein was found to have an apparent molecular weight of 59 $\mathrm{kDa}$, migrated slightly slower than desmin (Fig. 6.1) and, as observed in twodimensional gel electrophoresis, appeared to have a neutral to slightiy basic pl (data not shown). Because of its restricted tissue distribution the 59.kDa protein has been designated 'smoothelin'.

\section{Molecular cloning and characterization of smoothelin.}

A cDNA expression library was constructed from poly $(A)^{+}$RNA isolated from human colon smooth muscle tissue. This library was screened with monoclonal antibody R4A. Of the 25,000 plaques plated 14 were immunoreactive with R4A. The size of the cDNA inserts varied between 600 and $1550 \mathrm{bp}$, indicating that the epitope of R4A is located at least 150 amino acid residues away from the carboxy terminus (the last $150 \mathrm{bp}$ are non-coding). All clones isolated appeared to contain sequences similar to the two largest clones, as deduced from restriction patterns. The complete nucleotide sequence and deduced amino acid sequence are presented in Fig. 6.3A. To check whether the largest clone contained a full size CDNA, a 5'RACE reaction was performed. No additional sequence was lound which indicated that the $1600 \mathrm{bp}$ clone was indeed full size. The 1554 bp cDNA contains a 1113 bp open reading frame that encodes a putative protein of 371 amino acids. Other open reading frames were much shorter. Smoothelin has a relatively high number of serine $(11.5 \%)$, alanine $(10 \%)$, arginine $(8.4 \%)$ and methionine $(3.5 \%)$ residues. The calculated molecular weight of the protein deduced from largests open reading frame of smoothelin is $40.406 \mathrm{kDa}$ with a pl of 8.5 .

Western blotting of smoothellin cDNA transfected COS7 cells revealed a $59 \mathrm{kDa}$, $\mathrm{R} 4 \mathrm{~A}$ reactive protein, the same size as the protein found in smooth muscle tissues such as colon (Fig. 6.4, lanes $\mathrm{c}$ and a). Transcription and translation of the full-size cDNA of smoothelin in a prokaryotic expression system gave an approximately $60 \mathrm{kDa}$, R4A immunoreactive molecule (Fig. 6.4, lane b). The calculated molecular weight of this product was about $50 \mathrm{kDa}$ due to addition of the 6 His-tag and translation of the $5^{\prime}$ non-coding CDNA region. Further analysis shows that the putative protein contains two Asn-X-Ser sequences (residues 151 and 277). which are required for asparagine-linked $\mathrm{N}$-glycosylation (Pless and Lennarz, 1977).

Sequence homology at the nucleic acid and protein level with members of the spectrin superfamily, dystrophin, utrophin, beta-spectrin and alpha-actinin was found for the region between amino acid residues 270 and 331 of smoothelin (Fig. 6.3B). Even if conserved mutations are not included, this region of smoothelin showed $39 \%$ homology with human and mouse dystrophin, $46 \%$ homology with human and mouse beta-spectrin, and $34 \%$ for human utropin. Homologies with alpha-actinin varied from $46 \%$ for human to $26 \%$ for D.discoideum. For the members of the spectrin family this region is located directly following the suggested actin binding site of these molecules.

The secondary structure of the putative protein was analysed by PHD, a neural 
network program, (Rost and Sander, 1993, 1994). Since no homologous sequences were available in the Swissprot databank the expected accuracy of this method was estimated between 62 and $66 \%$. Smoothelin has two regions with a potential helical formation: between amino acid residues 6 and 63 , and between 179 and 229. In addition, in the region showing homology with the spectrin family proteins short streches are found with helical potential (Fig. 6.3A). However, even the rather large helical structures of smoothelin are considerably smaller than the ones found in, for instance, intermediate filament proteins. Proline residues are found next to the first helical region and in a proline-rich stretch between residues 234 and 252 (> $35 \%$ ) preceding the region homologous to the spectrin family.

In situ hybridization with the 1600 bp cDNA demonstrated that the gene coding for smoothelin is located on human chromosome 22 (Fig. 6.2).

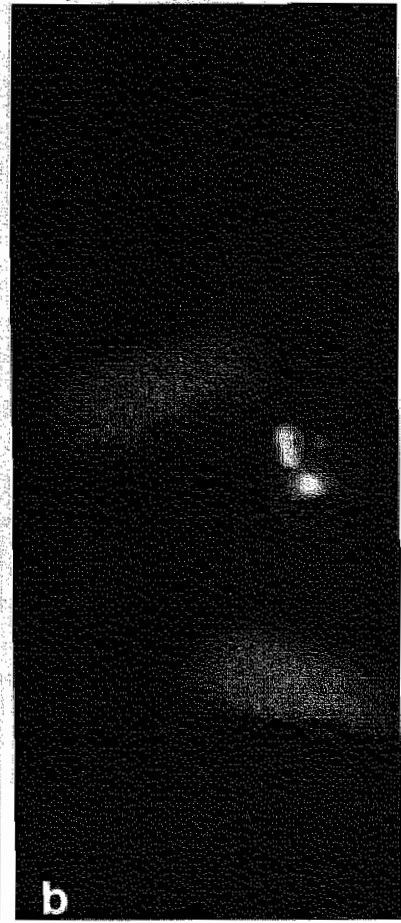

Fig. 6.2: Metaphase spread of normal human lymphocytes (a) were hybridized with smoothelin CDNA labeled with biotin (green signal) in combination with a digoxigenin labeled chromosome 22 centromeric probe (red signall. Arrow indicates the part of the metaphase spread shown in the higher magnification (b). 


\section{Expression of smoothelin.}

Northern blotting analysis of RNA from several human tissues containing smooth muscle cells, such as colon, stomach, uterus, and aorta showed a band of approximately 1500 bases after hybridization with the smoothelin CDNA probe (Fig. 6.5). No such hybridization was found with RNA isolated from brain, adipose tissue, cardiac and skeletal muscle, skin (data not shown) and intestinal epithelium (Fig. 6.5). Northern blot analysis of RNA of smooth muscle containing tissues derived from different species such as mouse, rat, dog and bovine showed a strong hybridization signal (under stringent hybridization conditions) and revealed no visible difference in mRNA size between these species.

The results of the Northern blotting analysis were in agreement with the immunohistochemical screening of a number of different human tissues such as stomach, uterus, colon, prostate, aorta and other arteries with monoclonal antibody R4A. Smooth muscle cells in all these tissue were positive whereas. other tissue types, such as striated muscle, myoepithelium, myofibroblasts in Dupuytren's nodules, epithelium, neural and connective tissues, were negative with R4A (Fig. 6.6). Analysis of different species evolutionary as distant as Xenopus leavis and human showed that R4A reacted with smooth muscle cells of these species, but no reaction was found with mouse, hamster and rat smooth muscle cells.

In smooth muscle tissue explants of uterine myoma the smoothelin mRNA concentration dropped sharply after transfer of tissue into culture medium. Smoothelin mRNA was no longer detectable by Northern blotting $12 \mathrm{~h}$ after removal of the tissue from the patients (Fig. 6.7). However, immunohistochemical and Western blot analysis of these tissue explants revealed that smoothelin protein remained present in the tissue up to 5 days after explantation (data not shown). The reduction in smoothelin mRNA and protein can not be attributed to degradation or necrosis of the tissue since GAPDH mRNA and proteins such as vimentin, desmin and $\alpha$-smooth muscle actin did not diminish. No smoothelin mRNA could be detected in primary cultures of cells derived from smooth muscle tissue (human myoma, human colon, bovine aorta) or in long term cultured human vascular smooth muscle cells.

\section{Subcellular localization and organization of smoothelin.}

Immunohistochemical analysis of several tissues revealed that smoothelin was abundantly present throughout smooth muscle tissues, but close observation of individual cells indicated an uneven distribution over the cytoplasm. Confocal laser scanning microscropy of double-stained tissue sections of myoma and colon indicated that the smoothelin protein appeared to be organized in filamentous structure. These structures did not colocalize with desmin filaments. After homogenization and differential centrifugation smoothelin immumoreactivity was found in the Triton-X100 non-soluble fraction of the homogenates. The same fraction in which cytoskeletal proteins such as desmin and actin were 


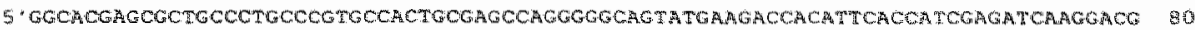

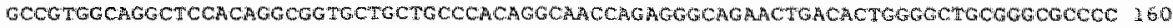

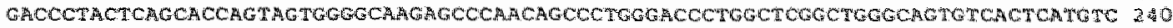

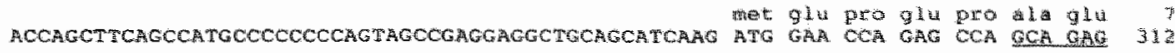

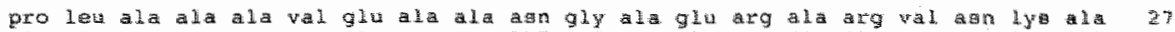

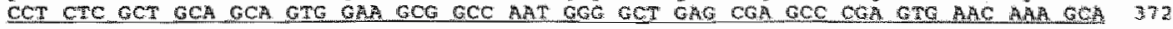

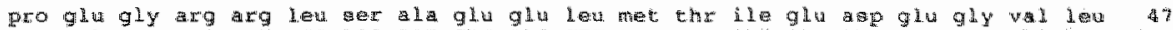

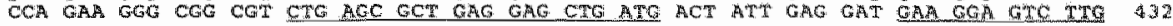

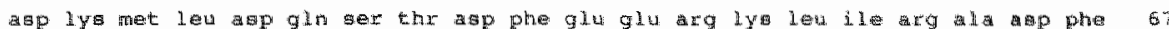

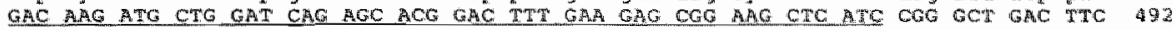

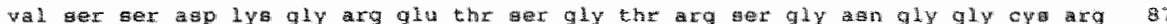
GTC AGC TCN GAC AAA GGA AGA GAG ACG MGC GGG ACA NGG AGC GGG AAC GQC $6 G C$ TGC

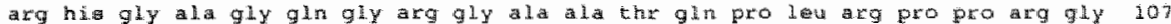
AGG CAC GGG GCC GOC CAG GGG AGS GGC GCG GCA ACA CAG OCA CTG MGA CCA CCA COA GGC 12

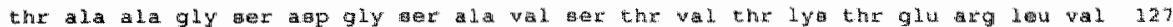

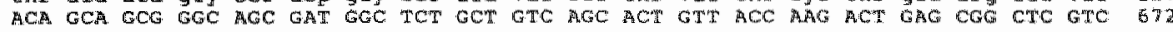

hig ser asm asp gly thr arg the ala arg thr the thr val gha ver ar phe vid arg 147 CAC TCC AAT GAT GGC ACA CGG ACG GCC COC ACC ACC ACA GTG GAG TCG AGT TTC GTG AGO 732

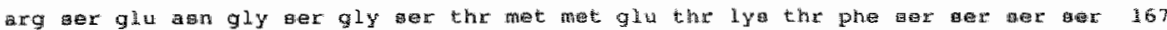
CGC TCG GAG ART GGC AGT GGC AGC ACC ATG ATC CAA ACC RAG ACC TTC "ICG TCT TCC TCE 792

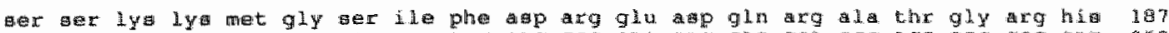
TCA TCC AAG AAG ATG GGE AGC ATC TTC GAC CGC GAO GAC CAG CGA GCC ACG GGC COC CAT

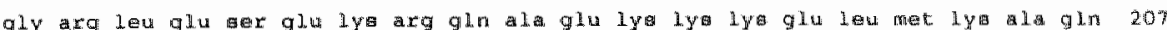

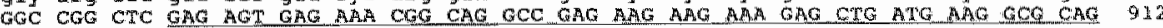

ger lew pro hys thr gex ala ar gln ala asg lya ala met ile glu ly lew glu iy $22 \%$ AGT CTG COC AAG ACC TCA GCC TGC CAG GCO CGC AAC OCC AIG ATT CAG ARG CTG GAG AMO 972

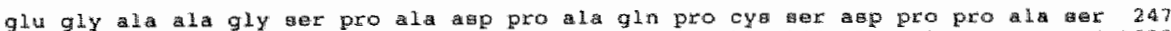
GAG GGE GCO GCC GGC AGC CCT GCG GAC CCC GCO CAG COG "GC ACC GAT CCA CCA GCT TCG 1032

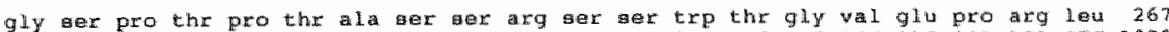
GGG TCC CCA ACG CCA ACA GCA TCA AGC AGA TOG TOO TGG ACH GGT GTC GAG CCA AGA DTC 1092

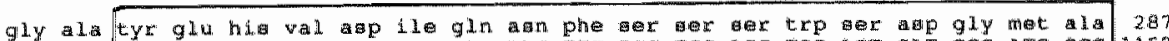
GGG GCC TAC GAG CAC GTC GAC ATC CAG AMC TTC TCO TCC AGC TGE AGT GAT GGG ATG

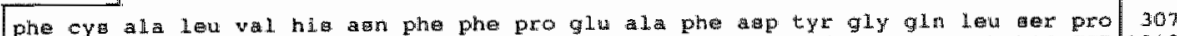
TTC TGT GCE CIG GTG CAC ARC TTC TTC CCT GAO GQC TIC GAC TAT GOG CAG CTT AGC CCT 1212

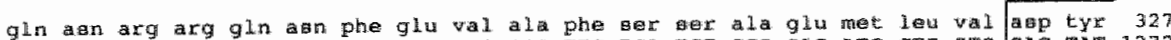
CAG AAC CGA CGC CAG AAC TTC GAG GTG GCC TTC TCA TCT GCO GAG ATG CTG GTS GAC TAT 1272

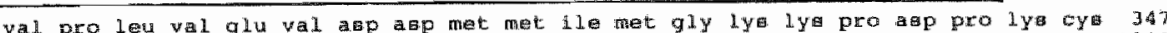
GTG CCC CTG GTG GAG GTG GAC GAC ATT ATG ATC ATG GGC AAG AAG CCE GAC GCE AAG TGT 1332

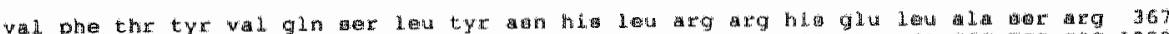

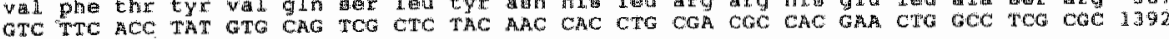

gly ly ly plo

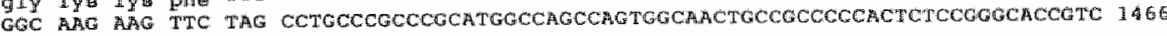

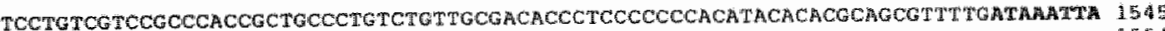

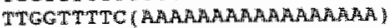

Fig. 6.3A: Nucleotide sequence of the smoothelin cDNA selected from a human collon smooth muscle cDNA library and the deduced amino acid sequence of the putative protein. The sequence with homologies to members of the spectrin super-family is boxed. Potential helical secondary structures are underlined. The polyadenylation signal is indicated with bold letters. Notice the number of proline and proline-alanine residues in the area preceding the boxed sequence. 
protedr

pose iston

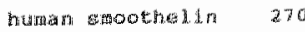

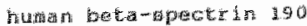

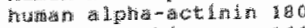

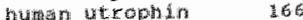

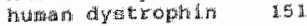

然efuteres

hom $\log$

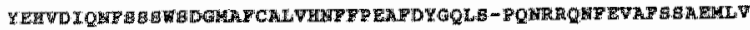

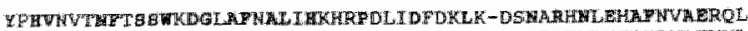

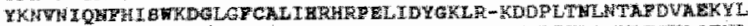

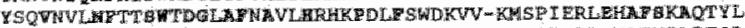

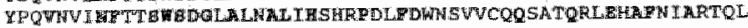

4

Fig. 6.3B: Amino acid sequence of homologous regions of human smoothelin, and mernbers of the spectrin family, human beta-spectrin, human alpha-actinin, human utropin and human dystrophin. Homologies are indicated by bold letters.

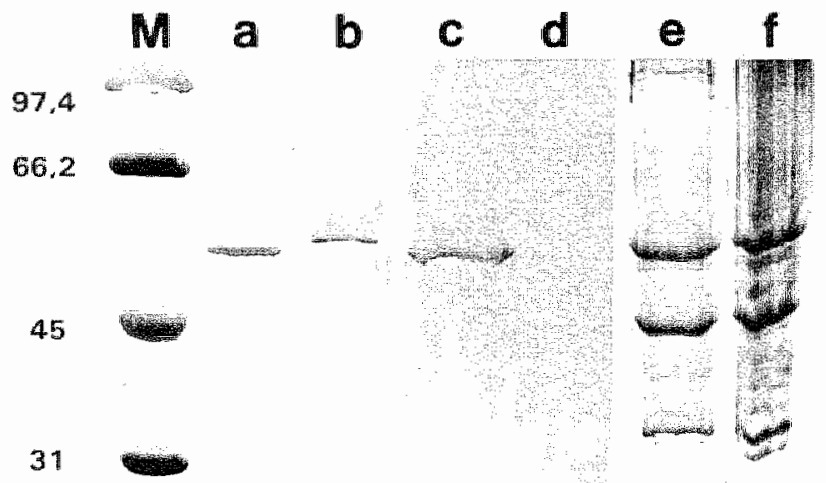

Fig. 6.4: R4A immunostained Wesitern blot of: human colon smooth muscle extract llane a), prokaryotic product based on the full-size CDNA in pOE9 (llane b)u3, COS7 cells transfected with pCDNA3-SMO (lane c) and COS7 cells transfected with pCDNA3 (lane d). Lanes $\theta$ and $f$ are Coomassie Brilliant Blue stained proteins corresponding with lanes $c$ and $d$, respectively. Marker lane is indicated by $M$.

found.

Since synthesis of smoothelin ceased in smooth muscle cell lines and in primary cultures of smooth muscle cells, transfection experiments were set up to reveal the cellular organization (and localization) of smoothelin. Transfection of thesmoothelin cDNA driven by a CMV promotor (pcDNA3-SMO) in COS7 cells resulted, 24 hours after transfection, in about $5 \%$ of the cells in extensive 
filamentous networks reactive with R4A (Fig. 6.8a). Observation of the cells after longer periods of transient smoothelin expression showed accumulation of R4A immunoreactive material in the cytoplasm, but no obvious changes in morphology and growth of the cells were seen. The filamentous networks are different from the ones observed for actin, tubullin or intermediate filaments keratin and vimentin. Double-immunostaining of the transfected COS7 cells showed that smoothelin does not colocalize with vimentin and keratin

intermediate filaments nor with F-actin (Fig. 6.8). Networks formed by tubulin and smoothelin differed considerably, which was most obvious for mitotic cells containing spindles. As mentioned above, Western blotting of pcDNA3-SMO transfected cells showed the synthesis of a $59 \mathrm{kDa}$ protein, reactive with $\mathrm{R} 4 \mathrm{~A}$ (Fig. 6.4). In cells transfected with the pcDNA3 plasmid no R4A reactive material was found in immunohistochemical and Western blot assays.

\section{Discussion}

Although smooth muscle and striated muscle cells share some structural proteins, such as desmin, or synthesize closely related isoforms of proteins, as for actin and myosin, large differences have been demonstrated in the construction and physiology of the contractile apparatus. For example, structural proteins such as titin and nebulin, that are part of the contractile apparatus in striated muscle cells, are not found in smooth muscle cells nor have structurally comparable molecules been identified as yet. However, a number of smooth muscle specific proteins, such as calponin, SM-22, h-caldesmon, filamin and metavinculin have been identified and characterized (Lees-Miller et al., 1987; Takahashi et al., 1988; Hock et al., 1990; Frid et al., 1992). Several of these smooth muscle specific proteins are associated with actin and myosin, i.e. the contractile apparatus, but so far no structural proteins exclusively expressed in smooth muscle cells have been identified. A novel protein is presented which is smooth muscle-specific, exhibits a filamentous organization and appears to be expressed in contractile type cells only. The protein has been designated smoothelin.

\section{Characterization of smoothelin.}

The nucleic acid and protein sequences of smoothelin have been elucidated and its secondary structure is predicted by computer analysis. The molecular weight as estimated from the cDNA open reading frame is $40 \mathrm{kDa}$ which is approximately $20 \mathrm{kDa}$ smaller than the size of the protein detected by Western blotting after SDS-PAGE (Fig. 6.4). The estimated molecular weight of the protein based on the full size cDNA is about $50 \mathrm{kDa}$ which is about $10 \mathrm{kDa}$ smaller than the prokaryotic product of this protein shown by SDS-PAGE (Fig. 6.4\%. A decreased SDS-binding capacity because of conformational properties of 
the alanine-proline sequences and the rigidity of the proline-rich region probably account for an increase in apparant molecular weight of about $10 \mathrm{kDa}$ (Berbers et al., 1983; Vaughan et al., 19931. Post-translational additions have to account for the other $10 \mathrm{kDa}$ increase of molecular weight found in eukaryotic cells. The presence of two asparagine-linked $\mathbb{N}$-glycosilation sites may be accountable for the missing $10 \mathrm{kDa}$.

Computer assisted structure analysis of the putative amino acid sequence revealed potential helical structures but they are relatively small compared to those found in intermediate filament proteins such as desmin and vimentin (Quax-Jeuken et al., 1983). The proline residues are found around the first helical structure and show a major concentration in a proline-rich region in the center of the protein. This proline-rich region is located between the second potential helical domain of smoothelin and the region homologous to the spectrin family (see below). The helical domains may be involved in formation of filamentous structures since transfection of smoothelin cDNA results in the formation of filaments in COS7 cells. This is in agreement with the results of the fractionation studies of smooth muscle tissues, suggesting that smoothelin is part of a non-soluble cytoskeletal network. In addition, immunohistochemical analysis by CSLM indicate smoothelin to be part of filamentous structures /data not showni. Nevertheless, there still is a possibility that the structures observed are the result of association of smoothelin with excisting cytoskeletal filaments. However, double staining immunofluorescence assays in COS7 cells indicated that interaction with intermediate filaments formed by keratin and vimentin as

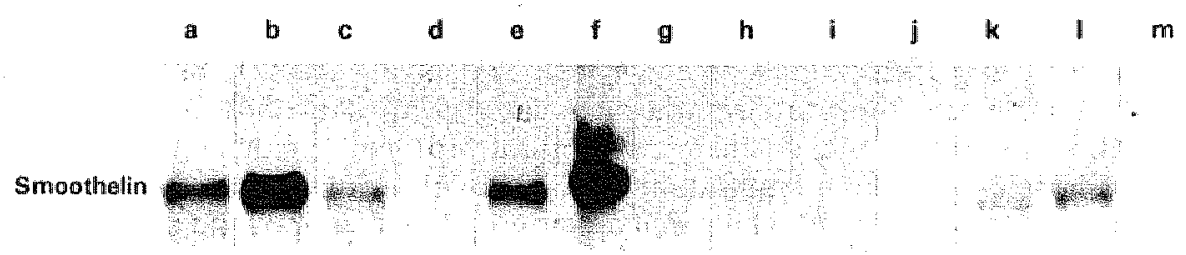

Fig. 6.5: Northern blot of a number of different tissues obtained from several species. All RNAs hybridizing to the ${ }^{32}$ P-labeled smoothelin CDNA probe were of the same size. but concentrations, as compared with GAPDH, varied. RNAs were extracted from the following tissues: mouse stomach (a), rat uterus (b), rat stomach (c), rat skeletal muscle (d), dog stomach smooth muscle (e), dog intestinal smooth muscle (f), dog intestinal epithelium $(g)$., bovine small intestinal smooth muscle (h), bovine skeletal muscle (i), bovine heart (j), human small intestinal smooth muscle ( $k$ ), human uterus (I), human intestinal epithelium (m). 

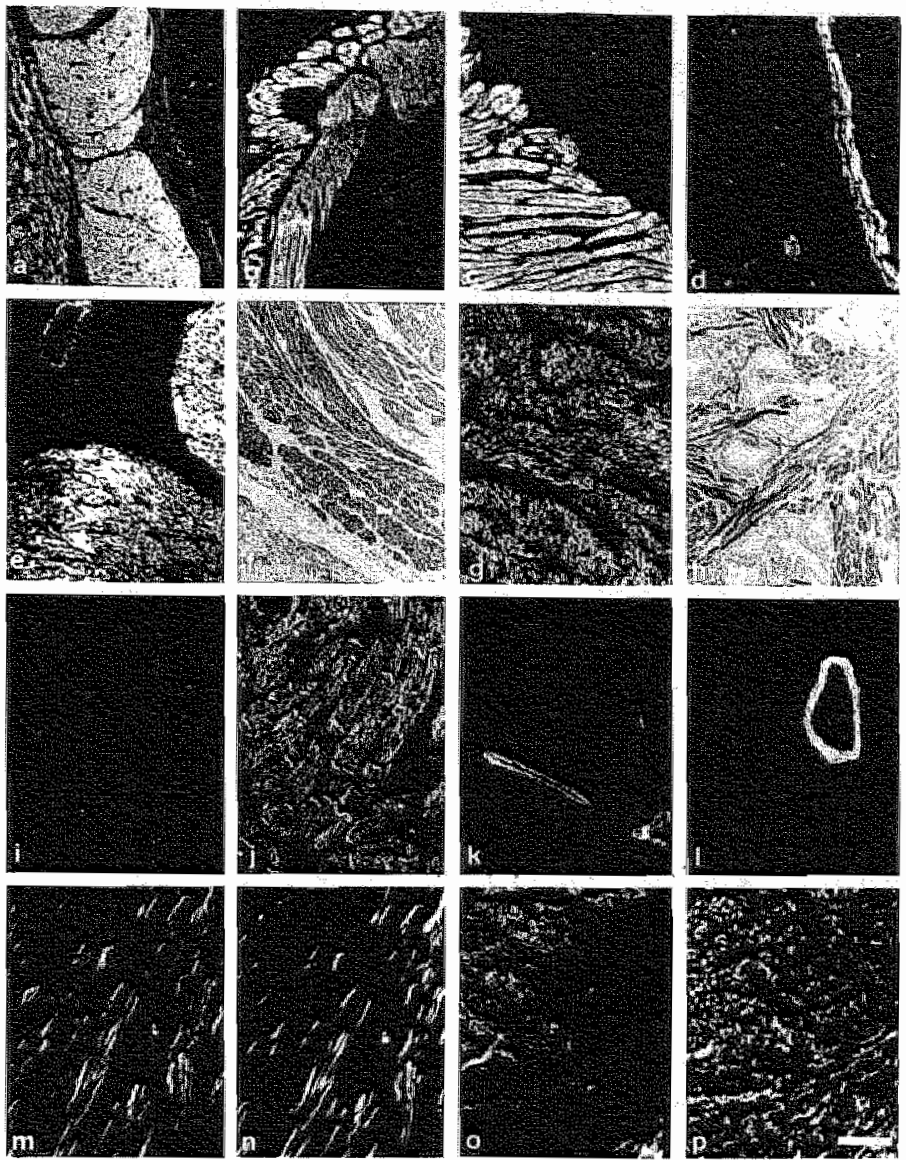

Fig. 6.6: Immunohistochemical screening of different species and tissues for the presence of smoothelin. Intestinal smooth muscle tissue of human (a). goat (b) and Xenopus leavis (d) and chicken oesophagus (c) were all positive for R4A. In human llarge intestine (e), stomach (f), uterus $(g)$ and prostate $(h)$ smooth muscle cells showed a strong reaction with $\mathrm{R} 4 \mathrm{~A}$ (f and h show peroxidase staining). In rabbit ( $k$ ) and cat (ll) heart tissue only smooth muscle cells surrounding the blood vessels are visualized by R4A. Double stained sections of human heart (i and i) and myoma ( $m$ and $n$ ) and incubated with R4A ( $i$ and $m$ ) or pDes if and $n$ ) show the absence of smoothin in heart muscle cells and colocalization in only part of the myoma smooth muscle. No colocalization of smoothelin (o) and vimentin (p) has been found, as demonstrated in myoma tissue after double staining with $R 4 A$ and $p$ Vim (o and p respectively). 
well as microfilaments or microtubules could be excluded, since staining patterns are largely different. Therefore, association with one of these excisting cytoskeletal networks seems unlikely in COS7 cells, but does not exclude such an association in smooth muscle celis.

Southern blotting (Van Eys et al "in preparation) and in situ hybridization indicate that no sequences with major homologies to smoothelin are present in the human genome. However, a 56 amino acids sequence near the carboxy terminal domain of smoothelin shows homology with dystrophin, utrophin, beta-spectrin and alpha-actinin. In these members of the spectrin family this sequence is part of the amino terminal domain, that has been demonstrated to bind to actin filaments (Winkelman et al., 1990; Baron et al., 1987; Dhermy, 1991; Winder et al., 1995). According to Karinch and coworkers (1990) a highly homologous 140 amino acid/16.5 kDa fragment of this domain contains the actual binding site(s) of actin. Other investigators have appointed three short sequences within this 140 amino acid sequence involved in actin binding (see: Winder et al., 1995). However, amongst the members of the spectrin familly the homology extends further towards the carboxy terminal for at least another 80 amino acids residues (Koening et al.,1988; Winkelman et al., 1990; Beggs et al." 1992; Tinsley et al., 1992). Smoothelin has a 56 amino acid sequence homologous to this 80 amino acid sequence (Fig. 6.3B). Taking in account the uncertainty of the actual sequences involved in actin binding by members of the spectrin family (see: Winder et al., 1995), it seems possible that the 56 amino acid sequence of smoothelin may function as (truncated) actin binding domain. On the other hand, the high degree of conservation may be indicative for a different functional domain shared amongst cytoskeletonmassociated proteins, although no function has been indicated yet.

\section{Expression of smoothelin.}

Smoothelin is only expressed in fully differentiated smooth muscle cells. Expression has been found in all smooth muscle tissues and in all vertebrate species investigated. The apparently high level of evolutionary conservation indicates that smoothelin is an important consituent of smooth muscle cells. In addition, its expression appears to be more stringently regulated as compared to other smooth muscle specific proteins. Smooth muscle cell components such as metavinculin, calponin. smooth muscle alpha-actin and smooth muscle myosin isoforms have been observed in non-smooth muscle cells in embryos, in culture and in pathologically affected striated muscle tissue (Babai et al., 1990; McHugh et al., 1991. Ausma et al., 19951. Also, most of these proteins have been found in rather early stages of differentiation, whereas smoothelin has been detected only in fully differentiated cells.

Several authors have suggested that smoath muscle cells can be divided into two phenotypes: the contractile and the proliferating/synthetic smooth muscle celltype (Gabbiani et al., 1981; Pauletto et al., 1994). Phenotype switches between these stages of differentiation have been suggested, but variation 


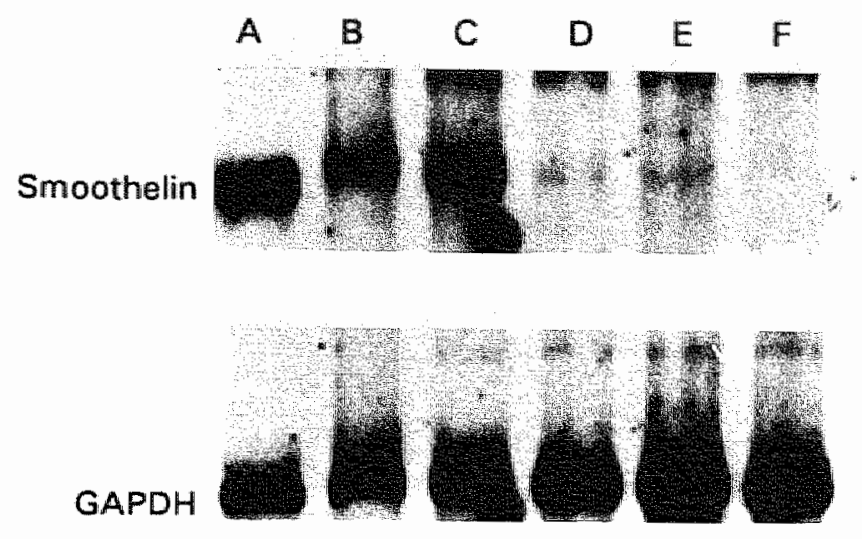

Fig. 6.7: Northern blot of RNAs extracted from human myoma explants kept in culture medium for $0,4,8,12,24$ and 48 hours. Hybridization with smoothelin (upper panel) and GAPDH (lower panel) CDNAs shows that smoothelin mRNA disappears between 8 and 12 hours after removal of the tissue from its natural environment. Hybridization with GAPDH CDNA demonstrates that this is not due to RNA degradation.

amongst smooth muscle cells derived from different organs and the lack of reliable differentiation markers have hampered investigations in this matter. Cultured smooth muscle cells and smooth muscle cell lines belong by definition to the proliferating phenotype. Our results showed that smoothelin is not expressed in cultured smooth muscle cells. The outcome from the experiments with the myoma explants supports this. The rapid drop in smoothelin mANA concentration after explantation indicates that expression of the smoothelin genedepends on factors, autocrine or bloodborne, or on continued (newrall) stimulation. Smoothelin filaments can be detected four or five days after explantation, indicating a rather slow turnover of the protelin once it has been incorporated into a filamentous structure. The absence of smoothelin in cells of primary cultures, even 4 hours after seeding, may indicate that cells with a contractile phenotype cells fail to settle in culture. The results of these experiments suggest a relation between smoothelin expression and comtractile potential. Screening of bloodvessels of different size and structure indicates that smoothelin is only found in vessels with contractile properties IVan der Loop, in preparation). Thus, different from other smooth muscle-specific proteins which appear to be expressed in both proliferative and contractile smooth muscle cells, smoothelin appears to be specific for contractile cells and may be a marker for this stage of differentiation. 

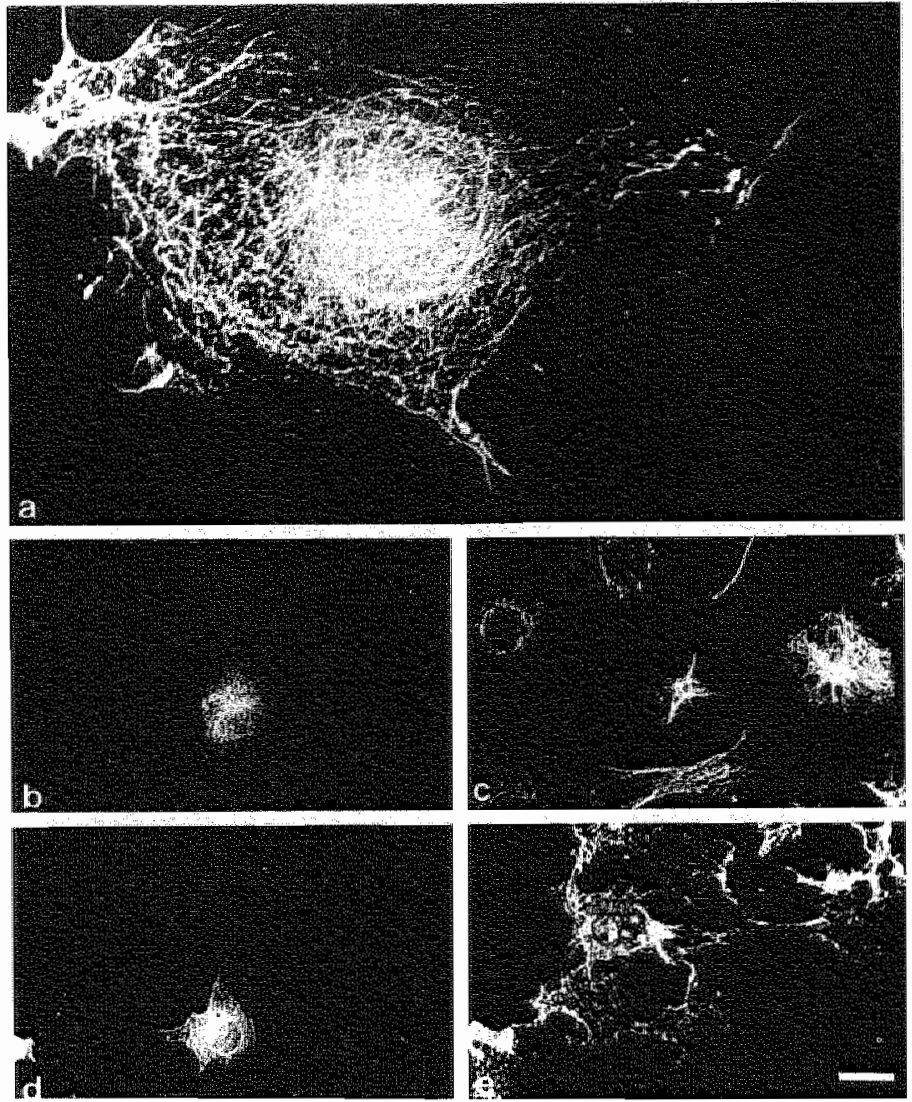

Fig. 6.8

Inmunofluoresce nce micrographs of COS7 cells transfected with the full-size human smoothelin cDNA.

Transfected cells clearly show filamentous structures reactive with anti-smoothelin F4A (a). Double immunofluorescence staining with R4A (b and $d$ ), with anti-vimentin (pVim) (c) and rhodamine phalloidine (e) shows that smoothelin filaments do not colocalize with intermediate filaments or stress fibers.

\section{EMBL accession number: $Z 49989$}

Acknowledgements: The authors are grateful to Luc Nieland and Jack Leunilssen (CAOS/CAMM Centre. Nijmegen) for assistance given with the deta bank screening, to Christine Voorter and Monique Vallinga for in situ hybridization and to Nicole Caberg and Paut Stassen for experimental contribution. We like to thank Prof. Dr. Jan-Willem Arends and Mr. Sjaak Baltus (Department of Pathology, Maastricht) for providing human tissues. We are indebted to Dr. Guilio Gabbiani (Department of Pathology, University of Geneva) for providing the long term cultured smooth muscle cells and human tissues samples.

This work was financially supported by the Dutch Heart Foundation (FvdL).

Monoclonal antibody against beta-tubulin (E7) was obtained from the Developmental Studies Hybridoma Bank maintained by the Department of Pharmacology and Molecular Sciences, Johns Hopkins University School of Medicin. Baltimore, MD, and the Department of Biology. University of lowa, lowa City, IA, under contract NO $1-H D-2-$ 3144 from the NICHD. 


\section{References:}

Altschul,S.F., Gish,W., Miller,W., Myers,E.W. Lipman,D.J. (1990) Basic local alignment search tool. J. Moll. Bloll., 215,403-410.

Auffray,C., Rougeon,F. (1980) Purification of mouse immunoglobulin heavy chain messenger RNAs from total myeloma tumor RNA. Eur.J.Biochem., 107, 393-314.

Ausma,J., Schaart, G.. Thoné,F., Shivalkar,B.,Flameng, W., Depre,C., Vanoverschelde J1. Ramaekers,F. Borgers, M. (1995) Chronic ischemic viable myocardium in man: Aspects of dedifferentiation. Cardiovasc. Pathol., 4, 29-37.

Aviv, A. . Leder,P. (1972) Purification of biologically active globin messenger RNA by chromatography on oligothymidylic acid celliulose. Proc. Nati. Acad. Sci. USA, 69. 1408-1412.

Babai,F., Musevi.Aghdam.J., Schurch,W., Royal,A., Gabbiani,G. (1990) Coexpression of alpha-sarcomeric, alpha-smooth muscle actin and desmin during myogenesis in rat and mouse embryos. Differentiation $44,132-142$.

Baron,M.D., Davison,M.D., Jones.P., Critchley,P.R. (1987) The sequence of a-actinin reveals homologies to spectrin and calmodulin. J. Biol. Chem., 262, 17623-17629.

Beggs,A.H., Byers,T.J., Knoll,J.H.M., Boyce,F.M., Bruns,G.A.P. Kunkel,L.M. (1992) Cloning and characterization of two human skelletal muscle a-actinin genes located on chromosomes 1 and 11 . J. Biol. Chem., 267, 9281-9288.

Berbers,G.A.M., Hoekman,W.A., Bloemendal ${ }_{\text {, }}$., de Jong.W.W., Kleinschmidit,T., Braunitzer, G. (1983) Proline- and alanine-rich $N$-terminal extension of the basic bovine beta-crystallin $\mathrm{B}_{1}$ chains. FEBS Lett., 161, 225-229.

Bochaton-Palliat,M.L., Gabbianni,F., Gabbianni,G (1994) Heterogeneity of rat aortic smooth muscle cell replication during development: correlation with replicative activity affter experimental endothelial denudation in adults. J. Submicrosc. Cytol. Pathol. 26, 18.

Borrione,A.C., Zanellato,A.M.C., Giurato "L.. Scannapieco,G., Pauletto,P., Sartore,P. (1990) Non-muscle and smooth muscle myosin isoforms in bovine endothelial cells. Exp. Cell Res. 190, 1-10.

Campbell,J.H., Kocher, O., Skalli,O., Gabbiani,G., Campbell,G.R. 11989) Cytodifferentiation and expression of alpha-smooth muscle actin mRNA and protein during primary culture of aortic smooth muscle cells: correlation with cell density and proliferative state. Atherosclerosis, 9, 633-643.

Chu,D.T.W. Klymkowsky.M.W. (1987) Experimental analysis of cytoskeletal function in early Xenopus laevis embryos. Development. 8, 140-142.

Church,G.M., Gilbert,W. (1984) Genomic sequencing. Proc. Natl. Acad. Sci. USA, 81. $1991-1995$.

Dhermy, D. (1991) The spectrin super-family. Biol. Cell, 71, 249-254. 
Duband.J-L. Gimona,M., Scatena.S., Small,J.V. (1993) Calponin and SM22 as differentiation markers of smooth muscle markers: Spatiotemporal distribution during avian embryanic development. Differentiation, 55, 1.11.

Ehler,E., Karlhuber,G., Bauer.H-C., Dreager,A. (1995) Heterogeneity of smooth muscleassociated proteins in mammalian brain microvasculature. Cell Tissue Res., 279, 393403 .

Feinberg, A.P., Vogelstein,B. (1983) A technique for radiolabeling DNA restriction endonuclease fragments to high specific activity. Anal. Biochem., 132, 6-12.

Frid,M.G., Shekhonin,B.V., Koteliansky,V.E., Glukhova,M.A. 11992) Phenotypic changes of human smaoth muscle cells during development: late expression of heavy caldesmon and calponin. Dev. Biol., 153,185-193.

Gabbiani,G., Schmid,E., Winter,S. Chaponnier,C., Chastonay,C.de, Vandekerckhove,J." Weber, K., Franke,W.W. (1981) Vascuiar smooth muscle cells differ from other smooth muscle cells: predominance of vimentin filaments and a specific alpha-type actin. Proc. Natl. Acad. Sci. USA, 78, 298-302.

Glukhova,M.A., Kabakov,A.E., Belkin,A.M.,Frid,M.G., Ornatsky,O.I., Zhidkova,N.I. Koteliansky.V.E. (1986) Meta-vinculin distribution in adult human tissues and cultured cells. FEBS Lett., 207, $139-141$.

Haeberle,d.R., Hathaway,D.R., Smith,C.L. (1992) Caldesmon content of mammalian smooth muscles. J. Muscle Res. Cell Motil., 13, 81-89.

Hock,R.S., Davis,G., Spiecer,D.W. (1990) Purification of human smooth muscle filamin and characterization of structural diomains and functional sites. Bilochemistry, 29, 9441 . 9451 .

Karinch.A.M., Zimmer,W.E. Goodman,S.R. (1990) The identification and sequence of the actin-binding domain of human red blood cell beta-spectrin. J. Biol. Chem., 265 , $11833-11840$.

Koening.M., Monaco,A.P., Kunkel,L.M. (1988) The complete sequence of dystrophin predicts a rod shaped cytoskeletal protein. Cell, 53, 219-228.

Köhler,G. Milstein,C. (1975) Continuous cultures of fused cells secreting antibody of predefined specificity. Nature, 256, $495-497$.

Laemmli,U.K. (1970) Cleavage of structural proteins during the assembly of the heads of bacteriophage T4. Nature, 227, 680.685.

Lees-Miller, J.P., Heeley,D.H., Smillie,L.B. 11987 ) An abundant and novel protein of 22 $\mathrm{kDa}$ (SM22) is widely distributed in smooth muscle. Biochern. J., 244, 705-709.

Malmquist, U., Arner, A. (1990) Isoform distribution and tissue content of contractile and cytoskeletal proteins in hypertrophied smooth muscie form rat portal vein. Circ. Res. 66. $832-845$

McHugh, K.M., Crawford.K., Lessard,J.L. (1991) A comprehensive analysis of the developmental and tissue-specific expression of the iscactin multigene family in the rat. 
Dew. Biol., 148, 442-458.

Nagal,R., Kurow,M. Babil.P., Periassamy.M. 1989 ldentification of two types of smooth muscle myosin heavy chain isoforms by cDNA cloning and immunoblot analysis. J. Biol. Chem., 264, 9734-9737.

Manaev, A.K., Shirinsky.V.P., Birukov,K.G. 119911 Immunofluorescent study of heterogeneity in smooth muscle cells of human fetal vessels using antibodies to myasin. desmin, and vimentin. Cell Tissue Res., 266, 535-540.

North,A.J., Gimona,M., Cross,R.A., Small,J.V. (1994) Calponin is localised in both the contractile apparatus and the cytoskeleton of smooth muscle cells. J. Cell Sci., 107, 437-444.

O'Farrell,P.H. (1975) High resolution two-dimensional electrophoresis of protein. J.Biol. Chem., 230, 4007-4021.

Paulletto,P., Sarzani,R., Rappelli,A., Chiavegato,A., Pessina,A.C., Sartore,S. (1994) Differentiation and growth of vascular smooth muscle cells in experimental hypertension. Am. J. Hypertens. 7,661-674.

Pless,D.D., Lennarz,W.J. (1977) Enzymatic conversion of proteins to glycoproteins. Proc. Natl. Acad. Sci. USA, 74, 134-138.

Quax-Jeuken,Y.E.F.M., Quax.W.J., Bloemendal,H. (1983) Primary and secondary structure of hamster vimentin predicted from the nucleotide sequence. Proc. Natl. Acad. Sci. USA, 80, 3548-3552.

Ramaekers,F.C.S. Puts,J.J.G. Moesker,O., Kant,A., Jap.P.H.K., Herman,C." Vooijs, G.P. (1983) Antibodies to intermediate filament proteins in the immunohistochemical identification of human tumours: an overview. Histochemical $J_{0, t}$ $15,691-713$.

Ramaekers,F.C.S., Moesker,O., Huijsmans,A., Schaart,G., Westerhof,G., Wagenaar,SjSc., Herman,C..J. Vooijs, G.P. (1985) Intermediate filament proteins in the study of tumor heterogeneity: an in-depth study of tumors of the urinary and respiratory tracts. Ann. NY Acad. Sci., 455,614-634.

Rost,B. Sander, C. 11993 ) Prediction of protein secondary structure at better than $70 \%$ accuracy. J. Mal. Biol., 232, 584-599.

Rost, B., Sander,C. 119941 Combining evolutionary information and neural networks to predict protein secondary structure. Proteins, 19, 55-77.

Sambrook,J., Fritsch.E.F., Maniatis,T. (1989) Molecular cloning: A laboratory manual. Cold Spring Harbor, New York: Cold Spring Harbor Laboratory Press.

Sanger,F., Coulson,A.R., Barrell,B.G., Smith,A.J.H., Roe,B.A. (1980) Cloning a single stranded bacteriophage as an aid to rapid DNA sequencing. J. Mal. Biol. 143, 161.178.

Sartore,S., De Marzo,N., Borrione,A.C. Zanellato,A.M.C., Saggin,L., Fabri,L., Schiaffino,S. (1989) Myosin heavy-chain isoforms in human smooth muscle. Eur. $\mathcal{J}$ Biochem., 179, 79-85. 
Schaart,G., Pieper,F.A., Kuipers,H.J.H., Bloemendal,H., Ramaekers,F.C.S. (1991) Baby hamster kidney (BHK-21/C13) cells can express striated muscle type proteins. Differentiation, $46,105-115$.

Skalli,o., Ropraz,P., Trzeciak,A.Benzonana,G., Gillesen,D., Gabbiani,G. (1986) A monoclonal antibody against allpha-smooth muscle actin: a new probe for smooth muscle differentiation. J. Cell Biol., 103, 2787-2796.

Takahashi,K., Hiwadd,K., Kokubu,T. (1988) Vascular smooth muscle calponin: a novel T-like protein. Hypertension. 11,620-626.

Takahashi,K., Nadal-Ginard,B. (1991) Molecular cloning and sequence analysis of smooth muscle calponin. J. Biol. Chem., 266, 13284-13288.

Takeuchi,K. „Takahashi,K. Abe.M., Nishida,W., Hiwada,K., Nabeva,T., Maruvama,K. (1991) Comlocalization of immunoreactive forms of calponin with actin cytoskeleton in platelents, fibroblasts and smooth muscle. J. Biochern., 109, 311-316.

Tinsley,J.M., Blake,D.J., Roche,A., Fairbrother,U., Riss,J., Byth,B.C., Knight,A.E., Kendrick-Jones,J., Suthers,G.K., Love, D.R., Edwards,Y.H., Davies,K.E. (1992) Primary structure of dystrophin-related protein. Nature, 360, 591-593.

Turner,C.E. Burridge,K. (1989) Detection of metavinculin in human platelets using a modified talin overlay assay. Eur. J. Cell Biol., 49, 202-206.

Uetsuki,T., Nabeshima,Y., Fujesawa-Sehara,A. Nabeshima,Y. (1990) Regulation of chicken embryonic myosin light-chain (L23) gene: excilstence of a common regulatory element shared by myosin light chain genes. Mol. Cell. Biol., 10, 256.2-2569.

Vaughan,K.T., Weber,F.E., Einheber,S., Fischman,D.A. (1993) Molecular cloning of chicken myosin-binding protein (MyBP) $\mathrm{H}(86-\mathrm{kDa}$ protein) reveals extensive homology with MyBP-C (C-protein) with conserved immunoglobulin $\mathrm{C} 2$ and fibronectin type III motifs. J. Biol "Chem., 268, 3670-3676.

Voorter, C., Joos, S., Bringuier, P-P., Vallinga, M., Poddighe,P., Schalken,J., Du Manoir,S., Ramaekers,F., Lichter ${ }_{\text {P. }}$. Hopman.A. (1995) Detection of chromosomal imbalances in transitional cell carcinoma of the bladder by comparative genomic hybridization. Am. J. Pathol., 146, 1341-1354.

Windar,S.J., Himmings,L., Maciver,S.K., Bolton,S.J., Tnsley,J.M., Davies,K.E. Crithley,D.R. Kendrick-Jones, J. (1995) Utropin actin binding domain: analysis of actin binding and cellular targeting. J. Cell Sci., 108,63-71.

Winkelman,J.C., Chang,J-G. Tse.W.T., Scarpa,A.L., Marchesi,V.T., Forget,B.G. (1990) Fullerength sequence of the cDNA for human erythroid beta-spectrin. J. Biol. Chem.. * $265,11827-11832$ 


\title{
7
}

\section{Smoothelin: a marker of differentiated human smooth muscle cells in normal arteries and arteriosclerotic lesions.}

\author{
Frank T.L. van der Loop, Giulio Gabbiani, \\ Frans C.S. Ramaekers, and Guillaume J.J.M. van Eys.
}

Arteriosclerosis, Thrombosis, and Vascular Biology:

manuscript based on this chapter submitted for publication.

Smoothelin is a filamentous constituent of the cytoskeleton, specific for differentiated (contractile) smooth muscle cells (SMC) in a broad range of species. Smoothelin was not detected in cells with smooth muscle-like characteristics, nor in skeletal or cardiac muscle or any other tissue type. In this study the expression of smoothelin in human vascular SMC was investigated in rellation to other myogenic differentiation markers, i.e. desmin, vimentin and $a$ smooth muscle specific actin (aSMA). A large population of aortic and large muscular artery SMC was negative for smoothelin, but contained vimentin in addition to aSMA. Some smoothelin-positive cells, also expressing desmin and aSMA, were found in these vessels: they expressed smoothelin more abundantly than desmin. The media of small muscular arteries contained SMC that were positive for smoothelin and desmin, whereas the vimentin-positive SMC-type was hardly present. Smoothelin was also detected in longitudinally positioned bundles of SMC in the intima and in the vasa vasorum, but was absent in capillaries, pericytic venules, and veins. The presence of smoothelin in normal vascular SMC appears to be correlated to the features activity of the arterial vessel. Confocal scanning laser microscopy of muscular artery SMC indicated a filamentous organization of smoothelin that is different from the staining patterns of desmin, vimentin or aSMA. In a number of arteriosclerotic lesions of femoral arteries smoothelin-positive cells were detected in the media, in the atheromatous plaque and in the intimal thickening. These areas also contained tenascin, indicating that the tissue is in a remodelling process. Smoothelinpositive cells were mainly present at the luminal surface of advanced lesions. We suggest that smoothelin expressing SMC are fully differentiated, and that the 
presence of a relatively high percentage of such smoothelin-positive cells may indicate that these plaques are no longer expanding.

\section{Introduction}

Smooth muscle cells (SMC) of the cardiovascular system are the most abundant cell type in blood vessel walls. These SMC are arranged in concentric layers: the tunica intima, the tunica media, and the tunica adventitia. They occur in all vessels with the exception of capillaries and pericytic venules. In the media of arteries SMC are intermingled with elastic lamellae and laminae, and appear as concentric, helically arranged bundles. Arterial SMC have been divided in lat least) two distinct states of differentiation, usually referred to as a synthetic and a contractile phenotype (reviewed by Thyberg et a., 1991111], the latter being predominant in the blood vessels of adults. These cells have a muscle-like appearance, contract in response to mechanical and chemical stimuli, and are involved in the control of blood pressure and blood flow. Synthetic type cells, with a more fibroblast-llike appearance, proliferate and produce extracellular matrix components. Contractile SMC can switch to the synthetic phenotype in respons to changes in a variety of physiological factors [2]. This potential is considered to play an important role both in angiogenesis and in the development of arteriosclerosis.

Intimal thickening with myofilament-rich SMC and without large accumulations of lipids is considered a physiological response to hemodynamic forces in specific artery locations [3]. Arteriosclerotic lesions can be classified as early lesions (initial lesions and fatty streaks), intermediate or transitional lesions (preatheromas) or advanced lesions (atheromas, fibro-atheromas, complicated fibro-atheromas, calcific- and fibrotic lesions $[3,4,5]$. In the early and untermediate lesions necrotic debris of foam cells and lipids accumulates gradually in the intima to form a lipid core region $[6,7,8]$. During the development of the arteriosclerotic plaque SMC from the media migrate into the intima, where they stant to divide and, thus, participate in the formation of intermediate or transitional lesions, and of advanced lesions $[4,8]$.

For the phenotype characterization of vascular smooth muscle cells, and for the discrimination between cells of the synthetic and of the contractile phenotype. the intermediate filament proteins (IFP) vimentin and desmin have been suggested as markers (reviewed by Thyberg et al., 1991) [1]. The properties of SMC with a specific IFP content varies among different blood vessels $[9,10,11]$. The cellular content of vimentin, desmin, a-smooth muscle actin (aSMA), myosin and tropomyosin changes when SMC shift from contractile into synthetiic SMC in wivo and in vitro $[12,13]$.

Recently, we have identified a novel SMC marker protein, smoothelin, that turned out to be useful to monitor SMC differentiation [14]. This filamentforming. $59 \mathrm{kDa}$ protein is exclusively expressed in fully differentiated (contractile) smooth muscle cells. A mouse monoclonal antibody directed against 
this protein revealed a broad species distribution. Smoothelin was not found in other mesenchymal or epithelial and neural tissues. Also, cells with smooth muscle-like characteristics, like myofibroblasts and myo-epithelial cells, as well as skeletal and cardiac muscle did not contain smoothelin [14].

This study elaborates on the distribution of smoothelin in the humain vascular system, both in normal blood vessels and in arteriosclerotic lesions.

\section{Materials and methods}

\section{Tissue distribution}

Samples of human arteries, both normal and arteriosclerotic, abdominal aortic aneurysm biopsies (immediately after surgery) and aortas (3-12 hrs post mortem) were either frozen in liquid nitrogen $\left(\mathrm{N}_{2}\right)$, mounted in Tissue-Tek 1 IOCT. compound; Miles inc. Elkhart, IN, USA) and stored at $-80^{\circ} \mathrm{C}$, or routinely embedded in paraffin. Samples of normal aorta and of early lesions were obtained from 6 months old Watanabe Heritable Hyperlipidemic (WHHL) rabbits and immediately frozen in $\mathrm{N}_{2}$. Foul micron thick sections were cut from the paraffin embedded material. From the frozen tissue, 3 to $5 \mu \mathrm{m}$ thick sections were cut at $-25^{\circ} \mathrm{C}$ and immediately fixed with methanol $\left(-20^{\circ} \mathrm{C}_{i} 5 \mathrm{~min}\right)$ and acetone $\left(-20^{\circ} \mathrm{C} ; 30 \mathrm{sec}\right)$ and air-dried for 3 hours. Alternatively, sections were air-dried over night at $20-22^{\circ} \mathrm{C}$ (room temperature; RT), and then treated for 5 min with $0.5 \%$ Triton $X-100$ (BDH Chemicals Ltd., Poole, UK) in phosphate buffered saline (PBS: $137 \mathrm{mM}$ sodium chloride; $13 \mathrm{mM}$ di-sodium hydrogen phosphate dihydrate; $3 \mathrm{mM}$ potassium dihydrogen phosphate, $\mathrm{pH}$ 7.4; Merck, Darmstadt, Germany), followed by a PBS washing step for 5 min.

\section{Antibodies}

Antibodies used in this study are:

1. The monoclonal antibody R4A against smoothelin was obtained after immunization of BalB/C mice with a high salt/Triton $X-100$ extracted preparation of chicken gizzard. Fusion procedure and cloning experiments were applied according standard protocols [15]. R4A is an antibody of the IgG1-subclass and was selected on basis of its reactivity pattern with smooth muscle cells of blood vessels of the human heart and smooth muscle tissue of the human intestine [14].

2. Polyclonal rabbit antiserum to purified chicken gizzard desmin [16],

3. Affinity-purified polyclonal rabbit antiserum to desmin [17].

4. Mouse monoclonal antibody RD301 to desmin [18].

5. Monoclonal antibody anti-aSm-1 to $a$-smooth muscle actin $\| 19 \rrbracket$.

6. Affinity-purified polyclonal rabbit antiserum to bovine lens vimentin [20].

7. The mouse monoclonal antibody RV2O3 to vimentin [21]].

8. The mouse monoclonal antibody $\mathrm{T} 2 \mathrm{H} 5$ to human tenascin, purchased from Euro-Diagnostica B.V. (Apeldoarn, The Netherlands) [22]. 


\section{Immunohistochemistry}

\section{* Immunofluorescence assays on frozen tissue sections}

Indirect immunofluorescence assays have been performed according to standard procedures. In brief, the methanol/acetone or Triton $X-100$ treated sections were incubated with the primary antibody for $30 \mathrm{~min}$ (RT), and washed three times (10 min each) with PBS. The appropriate fluorescein isothiocyanate (FITC)- or Texas Red (TR) conjugated secondary antibodies (Southern Biotechnology Associates (SBA) Inc., Birmingham, Alabama, USA) were applied for $30 \mathrm{~min}$ (RT). After washing with PBS, the immunofluorescent stained tissues were mounted in Mowiol (Hoechst, Frankfurt, Germany). For double-labelling studies the incubation steps were repeated with primary and secondary antibodies of different subclasses or species. Sections were analysed with a Bio-Rad MRC-600 confocal scanning laser microscope (CSLM; Bir-Rad Laboratories, Richmond, CA, USA), equipped with a Crypton/Argon mixed gas laser (llon Laser Technology, Salt Lake City, UT, USA) with two separate wavelengths for the excitation of FITC $(488 \mathrm{~nm})$ and TR $(568 \mathrm{~nm})$, and mounted on a Zeiss Axiophot microscope.

\section{* Immunohistochemistry on paratfin embedded tissue sections}

To stain paraffin embedded arteries with R4A, sections had to be pretreated in a microwave. In brief, the sections were deparaffinized, treated with ethanol $(100 \%)$, followed by methanol/hydrogen peroxide $(5 \%)$ and deminiralized water. The sections were placed in a $10 \mathrm{mM}$ citrate-buffer $(\mathrm{pH} 6.0)$ and heated in a microwave (3 times $5 \mathrm{~min}$ / [23]. After cooling in the citrate-buffer the sections were incubated with undiluted culture supernatant of the monocional antibody R4A. After washing in PBS, antibody binding was monitored with avidin-biotin complex peroxidase staining, performed according to the manifacturer's instructions (Vectastain ABC Kit, Vector, Burlingame, CA, USA). The peroxidase activity was revealed with 30\% 3,3'diaminobenzidine (Serva, Heidelberg, Germanyl, containing $0.015 \%$ hydrogen peroxide. Sections were counterstained with Mayer's haematoxylin, dehydrated and mounted in Eukitt [23].

\section{Gel electrophoresis and immunoblotting}

Approximately 40 cryostat sections $(20 \mu \mathrm{m}$ thick) of fresh frozen human tissue were collected, washed with $1 \mathrm{ml} \mathrm{PBS}$, and centrifuged for $5 \mathrm{~min}$ at $12.000 \times \mathrm{g}$. After centrifugation the pellet was subjected to a Triton $X-100$ extraction step: the pellet was suspended in $1 \%$ Triton $X-100,5 \mathrm{mM}$ ethylenediaminotetraacetic acid disodium salt dihydrate (EDTA; Merck), $0.4 \mathrm{mM}$ phenylmethylsulfonyl fluoride (PMSF; Merck) in PBS, pH 7.4, and extracted for 5 min on ice [21]. After centrifugation for $5 \mathrm{~min}$ at $12.000 \times \mathrm{g}$. the pellet was washed in $1 \mathrm{ml}$ PBS. After a final centrifugation step (5 min, $12.000 \times \mathrm{g})$, the cytoskeletal preparation was dissolved by boiling for $4 \mathrm{~min}$ in sample buffer, containing $2.3 \%$ sodium dodecylsulfate (SDS) and 5\% B-mercaptoethanol (Bio-Rad Laboratories) [24]. 
For one-dimensional SDS-gel electrophoresis, using a Mini Protean II Electrophoresis Cell (Bio-Rad Laboratories), polyacrylamide slab gels containing $0.1 \%$ SDS [24] were loaded with the cytoskeletal preparations. After electrophoretic separation, the proteins were stained with Page Blue 83 (BDH Chemicals Ltd.) or subjected to immunoblotting. The separated polypeptides were transferred from the slabgels to a nitrocellulose membrane (Schleicher and Schüll, Filter BA 85, Dassel, FRG) by blotting for 1 hour at $100 \mathrm{~V}$ in a cold $\left(4^{\circ} \mathrm{C}\right)$ buffer containing 25 mM Tris (Merck), 192 glycine (Merck), 0.02\% SDS, and $20 \%$ methanol (Merck) $[21,25]$. For protein detection two procedures using horse-radish peroxidase conjugated secondary antibodies (DAKO A/S) were applied. The first procedure, using 4-chloro-1-naphtol (Merck) and $0.12 \%$ hydrogen peroxide (Merck) in PBS, was applied when large amounts of protein were expected or when blots had to be reincubated one or two times with other primary antibodies [21]. For detection of low concentrations, a procedure using the chemiluminescence fluid $\mathrm{ECL}$ (Amersham International pcl, Amersham, UK) was applied according to the instructions of the manufacturer, after an extensive blocking procedure [26].
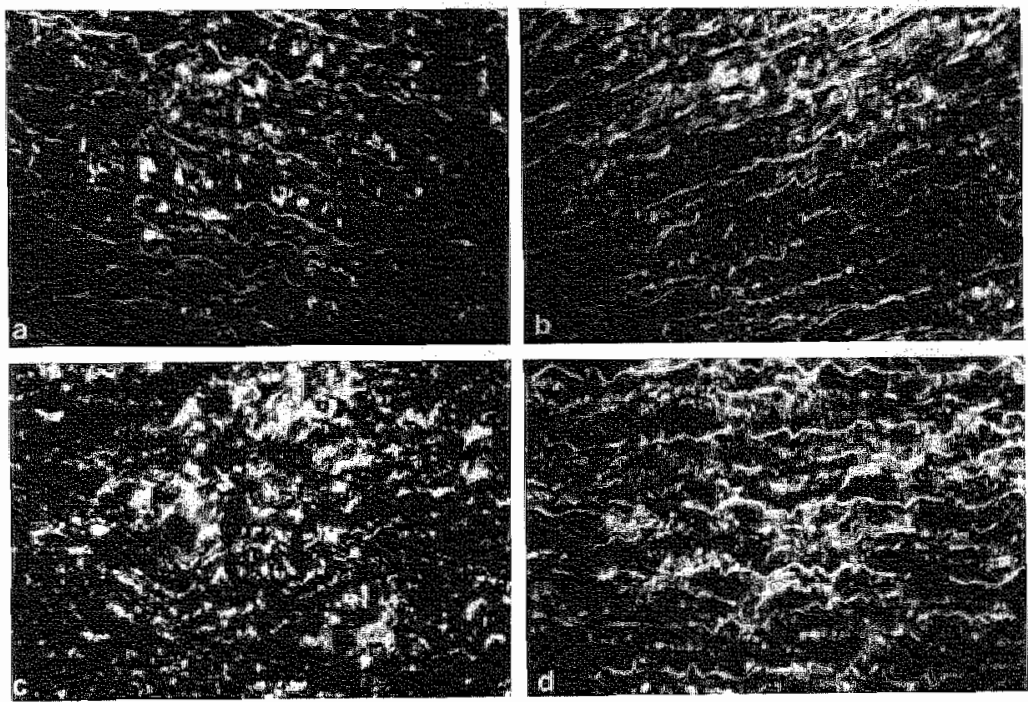

Figure 7.1: Immunofluorescense micrographs of human aorta, stained for (a) smoothelin. (b) desmin, (c) vimentin, and (d) a-smooth muscle actin. Bar indicates $40 \mu \mathrm{m}$.

\section{Primary and long term cultures of vascular SMC}

Vascular smooth muscle cells were obtained from bovine aorta, human uterine artery, and human mammary artery using standard procedures [27]. In brief, explants of these bloodvessels were enzymatically digested, and cells were collected and cultured in Dulbelco's Modified Essential Medium (Gibco BRL, 
Chapter

Figure 7.2
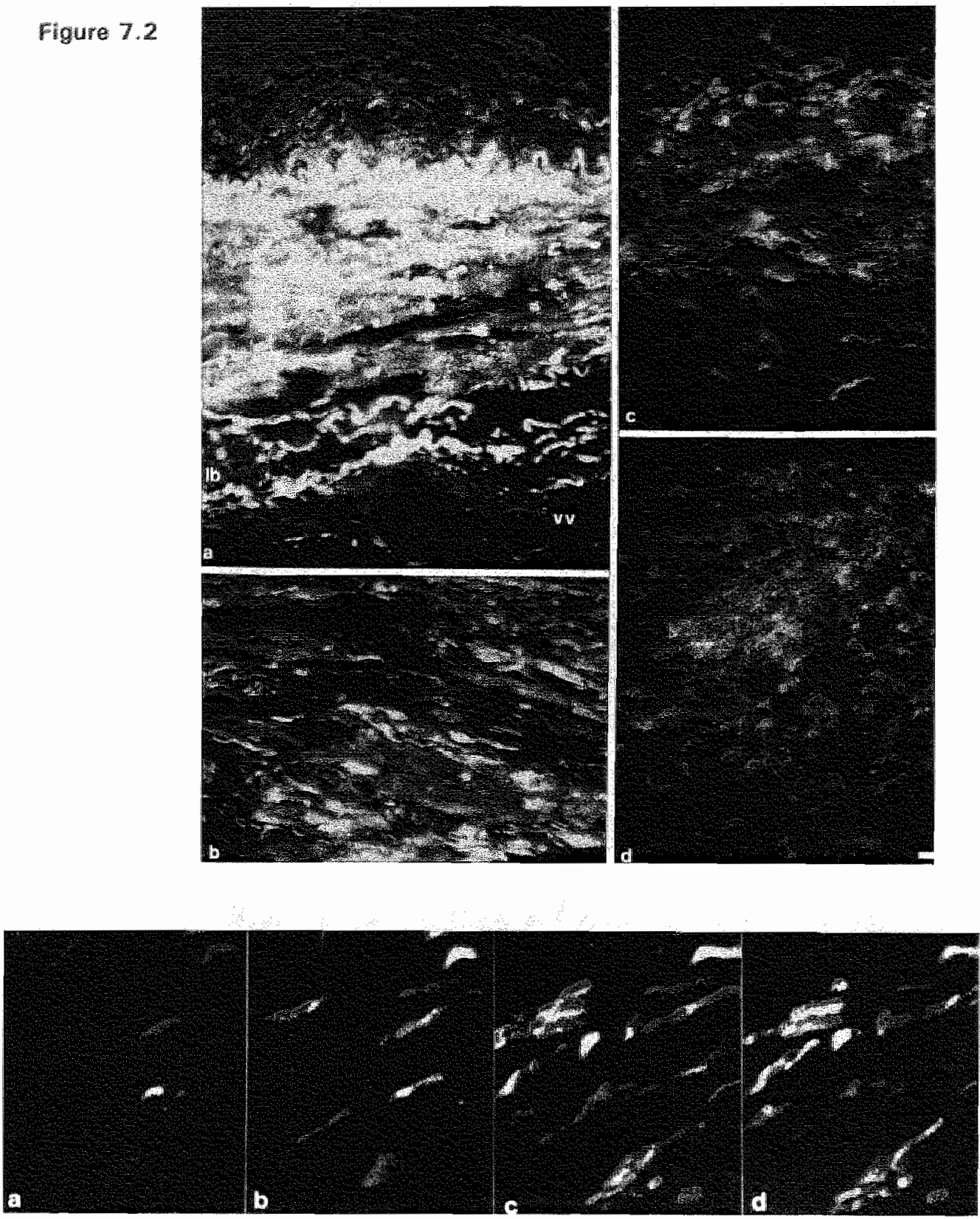

Figure 7.3 
Figure 7.2: Double-label immunofluorescense micrographs of (a) a human femoral artery with an arteriosclerotic lesion, (b,c) the tunica media of a human femoral artery, and (d) atheromatous material. In (a) and (b) smoothellin is detected with Texas Red. The yellow/green colour in (a) and $(b)$ is autofluorescense of the tissue, while desmin is detected with FITC in (b). Tenascin is detected with Texas Red in (c) and (d). while desmin is detected with FITC. Nuclei in (c) and (d) are stained with DAPI.

$\mathrm{b}=$ langitudinal bundless of SMC: $w=$ vasa vasorum. Bar indicates $25 \mu \mathrm{m}$.

Paisley, UK) supplemented with 15\% fetal calf serum (Gibco BRL). The bovine aorta SMC were allowed to settle on coverslips for $3-4$ hours before they were rinsed with PBS and fixed using methanol $\left(-20^{\circ} \mathrm{C} ; 3\right.$ times 2 seconds) and acetone $\left(-20^{\circ} \mathrm{C} ; 1 \mathrm{sec}\right.$. The human vascular SMC were cultured for at least 5 passages ("long term cultures") before fixation. Cells were used for single or double immunofluorescense staining and were not pretreated with Triton $x-100$.

\section{Results}

\section{Smoothelin distribution in blood vessels}

\section{* Elastic arteries}

The tunica media of elastic arteries, e.g. the aorta, contains up to 50 layers of elastic fibers. Interposed between the (autofluorescent) elastic lavers are SMC and some collagen. Staining of aorta sections revealed that these SMC belong to different types, expressing either desmin (fig. $7.1 \mathrm{~b})$ or vimentin $(\mathrm{fig} .7 .1 \mathrm{c})$, in addition to aSMA (fig. 7.1d). Only a limited number of media cells contained smoothelin (fig. 7.1a). Although double staining of aorta sections is lhampered by the autofluorescence of the elastic fibers, co-expresision of smoothelin and desmin was detected in the SMC of the media of the aorta. No smoothelincontaining cells were detected in the intima or in the adventitia.

In sections of two freshly frozen biopsies of abdominal aortic aneurysm no smoothelin- or desmin-positive SMC were detected, but vimentin containing SMC were present (not shown). Western blotting analysis confirmed the presence of vimentin and oSMA in aorta and aneurysm biapsies, but desmin and smoothelin were not detected under our conditions (table 7.1$)$.

Figure 7.3: Confocal Scanning Laser Microscopv analysis of the intracellular distribution of smoothellin (detected with FlTCl and desmin (detected with Texas Red). Subsequent levels $10.8 \mu \mathrm{m}$ apart) of the tissue were scanned (a-d), indicating that smoothellin and desmin in general have a different intracellular distribution pattern, although these markers occasionally appear to colocalize (yellow). 
Table 7.1: Results Western Blotting Analysis.

\begin{tabular}{lcccc}
\hline & Smoothelin & Desmin & Vimentin & aSMA \\
\hline Aorta & - & - & + & ++ \\
$\begin{array}{l}\text { Abd. Aorta } \\
\text { Aneurysm }\end{array}$ & - & - & + & + \\
$\begin{array}{l}\text { Sigmoid } \\
\text { artery }\end{array}$ & + & + & ++ & + \\
$\begin{array}{l}\text { Umbilical } \\
\text { Cord }\end{array}$ & - & + & + & ++ \\
Colon & ++++ & +++ & ++ & +++ \\
\hline
\end{tabular}

": detection using chemiluminescence technique.

Relative amount of antigen as indicated by signal intensity:

$\because,+,++,+++,++++$; negative to stronglly positive.

\section{* Muscular arteries}

In the media of the large muscular arteries smoothelin was detected in a limited number of SMC, both in frozen tissue sections (figs. 7.2a, 7.4a) and in sections of paraffin embedded tissue (fig. 7.4b). Smoothelin appeared to be more abundant as compared to desmin, i.e. both the staining intensity and the number of smoothelin-positive cells appeared to be higher (fig. 7.2b). The majority of the SMC contained vimentin.

In the media of small muscular arteries virtually all SMC contained smoothelin (fig. 7.4c). Co-expression of smoothelin and desmin was found in these SMC (compare figs. $7.4 \mathrm{C}$ and $7.4 \mathrm{~d}$ ). All cells that contained smoothelin were also expressing aSMA, whereas the vimentin-containing SMC-type was hardly fourd (not shown). The smoothelin antibody stained the longitudinal bundles of SMC as well as the SMC of vasa vasorum, located in the adventitia of the large muscular arteries (fig. 7.2a). The presence of smoothelin, desmin, vimentin and aSMA was confirmed by Western blotting analysis of a freshly frozen human sigmoid artery biopsy (table 7.1).

Double stained sections of large muscular arteries were studied using a confocal scanning laser microscope. Scanned images at different levels of these sections revealed that smoothelin and desmin staining patterns did not colocalize and were independently distributed (fig. 7.3a-d). Scanning images of smoothelin/actin or smoothelin/vimentin double stained sections also showed that there is no direct relation between filaments of these markers. 
* Capillaries, venules and veins

Smoothelin was not detected in capillaries, pericytic venules, and veins. Therefore, our results indicate that the thin laver of SMC in the media of the venous wall consists of cells that do not contain smoothelin.
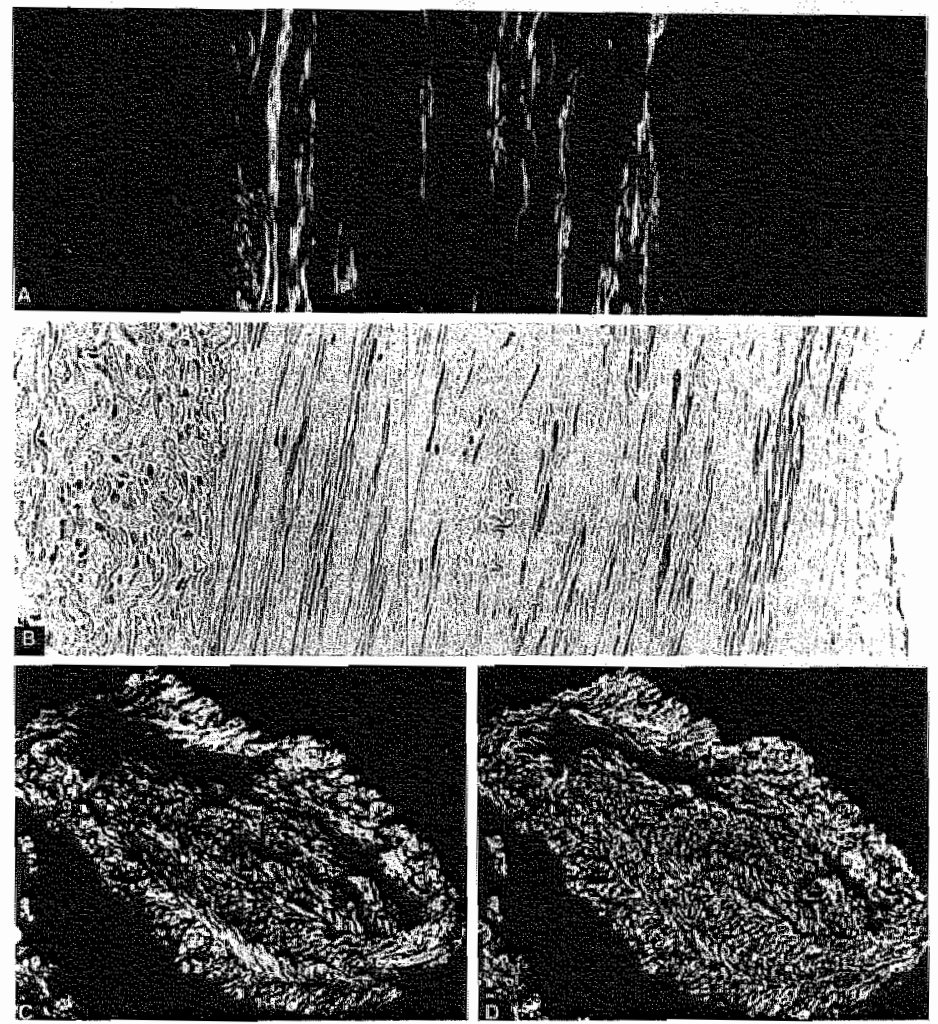

Figure 7.4: Immunostained sections of a large diameter muscullar artery $(a, b)$ and a small diameter muscular artery $(c, d)$. Smoothelin was found in a similar pattern both in frozen sections (a) and in paraffin embedded sections (b) of human femoral artery. Smoothelin (c) and desmin (d) were found in all SMC of a small muscular artery. Bar indicates 30 $\mu \mathrm{m}$.

\section{Smoothelin is absent in cultured vascular smooth muscle cel/s}

Smoothelin was not detected in primary cultured bovine aorta SMC (not shown). The majority of cells in these cultures contained vimentin and aSMA, and a minority of cells contained desmin and aSMA. Smoothelin was also absent in the long term cultures of human artery SMC (not shown). However, the cells did express aSMA in a stress fiber-like organization in combination with vimentin or desmin intermediate filaments. 
Smoothelin distribution in arteriosclerotic lesions

Arteriosclerotic lesions were investigated for smoothelin expression. Serial sections were stained with antibody R4A in combination with antibodies directed against other cytoskeletal proteins. Smoothelin-containing cells were found in the majority of the lesions. Since no early arteriosclerotic lesions in humans were available, early lesions were studied in 6 months old WHHL-rabbits. Lesions in these rabbits contained no smoothelin- or desmin-positive cells, but cells with vimentin and/or aSMA were detected (not shown). Smoothelin was also absent in intimal thickenings two weeks after aortic balloon injury.

In advanced human lesions smoothelin expression was found in SMC in demarcated areas. In general, the luminal side of the lesion contained more positive cells as compared to the intimal side $(f i g .7 .5 \mathrm{a}, \mathrm{c}$ ). The staining pattern of smoothelin appeared to be more stretched on the luminal side as compared with the more globular staining pattern on the abluminal side, indicating a more elongated morphology of the SMC in the luminal area of the lesion. Most cells in the arteriosclerotic lesions that contained smoothelin also expressed desmin lalthough not as abundant as smoothelin; fig. 7.5a,b), vimentin (with an organization pattern resembling desmin; fig. $7.5 \mathrm{c}, \mathrm{d}$ ), and aSMA (not shownl. In $10-20 \%$ of the lesions the luminal area in an intimal thickening was completely filled with cells that abundantly expressed smoothelin (fig. 7.2a).

The extracellular matrix component tenascin was demonstrated in the media underneath arteriosclerotic lesions (fig. 7.2c). These areas contained SMC both with and without smoothelin. Tenascin was also detected in the atheromatous material on top of these areas (fig. 7.2d).

\section{Discussion}

Vascular smooth muscle cells can be divided into different subclasses a) on basis of morphology, b) on basis of their expression patterns of structural proteins (like IFP or contactile proteins) $[9,10,11,27]$, or c) by their degree of differentiation (reviewed by Thyberg et al., 1991 [1]]. Cytoskeletal markers have been proposed as tools to discriminate between synthetic and contractile arterial SMC [1]. Switches in actin and myosin isoforms [28], or an increase of desmin and tropomyosin content in combination with a decrease in vimentin $[12,13]$ are indicative for SMC differentiation. Smoothelin, appears a useful adjunct to discriminate between the different SMC phenotypes, since immunohistological and biochemical data indicate that this cytoskeletal constituent is a marker for differentiated smooth muscle cells [14].

\section{Smoothelin distribution in normal blood vessels}

In a previous study we found that the presence of smoothelim is related to the contractile phenotype of the SMC, for example cultured, synthetic SMC did not 
contain this constituent. We suggested that there may be a correlation between smoothelin expression and contractile activity of the tissue [14]. Our present findings in the different types of vascular SMC corroborate with such a hypothesis. In the elastic and the large muscular arteries, that have to withstand tonically the high pressure that is generated by the heart, the SMC-type without expression of smoothellin and desmin, but with vimentin is mainly found. in contrast, SMC of small muscular arteries, that generate powerfull contractions to continue the pulsatile movement of the bloodflow in order to regulate the bloodpressure, contain mainly cells that contain smoothelin and desmin. Moreover, smoothelin is absent in veins that do not generate continous contractions. Thus the presence of smoothellin in vascular SMC appears to be correlated to isometric contractile activity. Filamentously organized smoothelin may provide an extra scaffold in contractile SMC to retain structural integrety of the cell. As far as the ellastic and the large diameter muscular arteries is concerned, blood vessel-type related differences in SMC-types, discriminated by their vimentin or desmin content, was described previously $[9,10]$. Our results corroborate these findings.

The absence of smoothelin in primary cultured bovine aorta SMC and in long term cultured smooth muscle cells from human uterine and mammary arteries may be caused by a shift towards the synthetic phenotype, caused by either a) the lack of locally produced or activated autocrine/paracrine factors or hormones, or b) by a selection for synthetic cells in long term cultures, or c) by the absence of contractile activity. The inverse relationship between proliferation and SMC-specific contractile protein expression was demonstrated in cultured human arterial muscle cells by Fager et al. $(1989 ;[29]\}$. The short time required to replace desmin with vimentin as the dominant IFP $(<24 \mathrm{hr})$ as well as the relatively fast shift from the $\alpha$ - to the $B$ - isoform of actin in cultured bovine carotid artery SMC was reported previously [30]. Smoothelin expression and organization is lost even faster as compared to these constituents.

\section{Smoothelin distribution in arteriosclerotic lesions}

The development of arteriosclerotic plaques is characterized by a migration of SMC from the media into the intima, and their modulation towards a synthetic phenotype $[31,32,33]$. Some of these cells remain quiescent, while others undergo proliferation within the intima, thus increasing the overall cellular mass of the lesion $[31,34]$. In experimental intimal thickening an increase in the number of SMC takes place mainly at the luminal surface of the plaque, and SMC number decreases after regeneration of the endothelium $[17,33]$. The SMC of the arteriosclerotic plaque do not only proliferate, but also secrete extracellular matrix components, thus forming a cap on the luminal side of the lipid core $[8,35]$. Babaev et al. $(1990 ;(36))$ have demonstrated that the plaque cap of advanced lesions contains many cells that possess the ultrastructurall features of modulated SMC, i.e., a well-developed endoplasmic reticulum and Golgi-apparatus. These cells express desmin as well as other cytoskeletal 

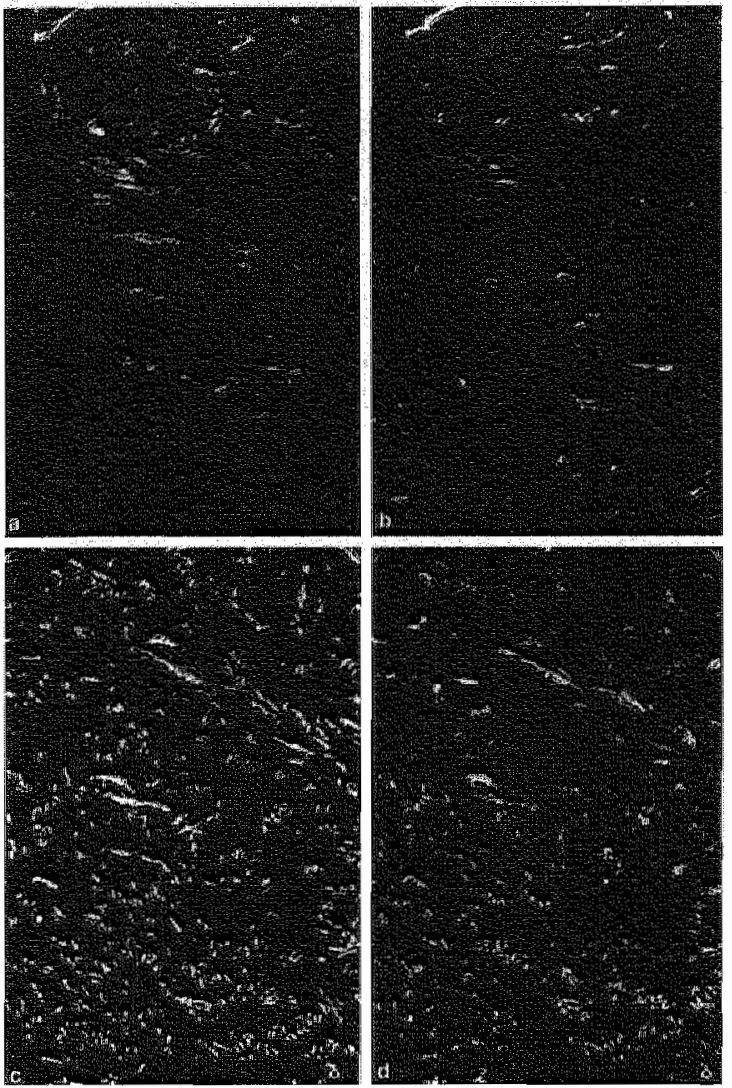

Figure 7.5:

Immunostained sections of an arteriosclerotic lesion, double stained with the monoclonal antibody against $(a, c)$ smoothelin and polyclonal antibodies against (b) desmin and (d) vimentin.

Bar indicates $30 \mu \mathrm{m}$.

proteins characteristic of differentiated SMC. Our findings suggest that the cells in these arteriosclerotic lesions do also contain smoothelin. The presence of smoothelin-containing SMC may be indicative of a reduced growth of the arteriosclerotic plaque.

The presence of smoothelin in the luminally located, supposedly non-proliferating SMC in advanced arteriosclerotic lesions, is in agreement with the hypothesis that smoothelin is a marker for fully differentiated (contractile) SMC. Tenascin, an extracellular matrix component that is produced by proliferating SMC $[37,38]$, has been demonstrated to be expressed in tissues that are in the process of remodelling [22]. Expression of tenascin was also demonstrated in embryonic arterial media [38,39]. Hedin et al. $(1991 ;[37])$ demonstrated that tenascin is present in the intima of normal arteries, but is not found in the media (where smoothelin is abundantly present) or the adventitia. The presence of tenascin 
was investigated in relation to smoothelin, because the expression of these two markers was expected to be inversely related. However. we have detected tenascin in the atheromatous material and in the media underneath the intimal thickening of an arteriosclerotic lesion, both at the intimal and at the adventitional side. These areas exist of both smoothelin-containing, contractile SMC and smoothelim-negative, synthetic cells. The co-occurence of smoothelin and tenascin in these areas may be an indication that the formation of an intimal thickening induces part of the contractile SMC to switch to a synthetic stage, which facillitates these latter cells to migrate into the neo-intima [40.41]. Therefore, the SMCs in the media near an arteriosclerotic lesion may be considered to be in a process of tissue remodelling, resembling an embryonic stage rather than to be in an adult state of organization.

In summary, smoothelin may be a usefull tool because it enables to discriminate fully differentiated, contractile SMC from non-differentiated SMC, and from cells with smooth muscle-like characteristics, such as myofibroblasts and myoepithelial cells. The distribution of smoothelin-positive cells may be related to the contractivity of the tissue where the SMC are located. Smoothelin may be a usefull tool in the evaluation of arteriosclerotic lesions, since it may allow to monitor the proliferative nature of such lesions.

Acknow/edgements:

The authors would like to thank $M$. Borgers (Janssen Research Foundation) for providing the bovine aorta smooth muscle cells, R. van der Zee (Department of Cardiology. University Hospital Maastricht) for providing the WHHLrabbit material, and Mrs. M. Redard (University of Geneva) for staining of the paraffin embedded tissues. Supported in part by the Swiss National Science Foundation Igrant $\mathbb{N}^{\circ}$ 31-40372.94). This work was financially supported by the Dutch Heart Foundation (FvdL). 


\section{References}

1. Thyberg J, Hedin $U$, Siölund $M$, Palmberg $\mathbb{L}$, Bottger BA. Regulation of differentiated properties and proliferation of arterial smooth muscle cells. Atherasclerosis 1991,10:966-990.

2. Pauletto $P$. Sarzani $A$, Rappelli $A$, Chiavegato $A$, Pessina AC, Sartore $S$. Differentiation and growth of vascular smooth muscle cells in experimental hypertension. Am. J. Hypertension 1994;7:661-674.

3. Stary HC. Composition and classification of human atherosclerotic lesions. Virchows Archiv. A 1992;421:277-290.

4. Stary HC, Chandler AE, Dinsmore RE, Fuister $V$, Glagov S, Insull W, Rosenfeld ME, Schwartz $C J$. Wagner WD, Wissler RW. A definition of advanced types of atherosclerotic lesions and a histalogical classification of atherosclerosis. Arterioscler. Thromb. Vasc. Biol. 1995;15:1512-1531.

5. Fuster $V$, Badimon L, Badimon JJ, Chesebro JH. The pathogenesis of coronary artery disease and the acute coronary syndromes. N. Engl. $J$. Med. 1992;326:242$250,310-318$

6. Guvton JR, Klemp KF. Transitional features in human atherosclerosis. Intimal thickening. cholesterol clefts, and cell loss in human aortic fatty streaks. Am. $J$. Pathol 1993;143:1444-1457.

7. Guyton JR, Klemp KF. Development of the atherosclerotic core region. Chemical and ultrastructural analysis of microdissected atherosclerotic lesions from human aorta. Arterioscler. Thromb. 1994;14:1305-1314.

8. Ross R. The pathogenesis of atherasclerosis: a perspective for the 1990s. Nature $1993 ; 362: 801-809$.

9. Schmid E, Osbiorn M. Rungger-Brändle E, Gabbiani G, Weber K, Franke WW. Distribution of vimentin and desmin filaments in smooth muscle tissue of mammalian and avian aorta. Exp. Cell Res. 1982;137:329-340.

10. Osborn M, Caselitz $J$. Püschel, Weber $K$. Intermediate filament expression in human vascular smooth muscle and in arteriosclerotic plaques. Virchows Arch. 4 $1987: 411: 449-458$.

11. Nanaev AK. Shirinsky VP, Birukov KG. Immunofluorescent study of heterogeneity in smooth muscle cells of human fetal vessels using antibodies to myosin, desmin and vimentin. Cel/ Tissue Res. 11991;266:535-540.

12. Travo $P$, Weber $K$, Osborn $M$. Co-existence of vimentin and desmin type intermediate filamentsin a subpopulation af adult rat vascular smooth muscle cells growing in primary culture. Exp. Cell Res. 1982;139:87-94.

13. Skalli $\mathrm{O}$, Bloom WS, Ropraz,P, Azzarone B, Gabibiani G. Cytoskeletal remodeling of rat aortic smooth muscle cells in vitro: relationships to culture conditions and analogies to in vivo situations. J. Submicrosc. Cvtol. Pathol 1986; 18:481 443.

14. Van der Loop FTL, Schaart G, Timmer EDJ, Ramaekers FCS, van Eys GJJM. Smoothelin, a novel cytoskeletal protein specific for smooth muscle cells. (sivimitited).

15. Köhler $G$. Milstein $C$. Continous cultures of fused cells secreting antibody of predefined specificity. Nature 1975;256:495-497.

16. Ramaekers FCS, Moesker O. Huijsmans A, Schaart G, Westeirhof G, Wagenaar SiS. . Herman CJ. Vooijs GP. Intermediate fillament proteins in the study of tumor heterogeneity: an in-depth study of tumors of the urinary and respiratory tracts. Arn. NY Acad. Sci. 1985;455:6»4-634.

17. Kocher O. Skalli O, Bloom WS, Gabbiani G. Cytoskeleton of rat aortic smooth muscle cells. Normal conditions and experimental intimal thickening. Lab. Invest. $1984 ; 50: 645-652$. 
18. Schaart G, Viebahn C. Langmann W, Ramaekers FCS. Desmin and titin expression in early postimplantation mouse embryos. Development 1989:107:585-596.

19. Skalli D, Popraz P, Trzeciak A. Benzonana G, Gillesen D. Gabbiani G. A monoclonal antibody against a-smooth muscle actin: a new probe for smooth muscle differentiation. $J$. Cell Biol. 1986;103:2787-2796.

20. Ramaekers FCS, Huijsmans A, Moesker O. Kant A, Jap P. Herman C, Vooijs $P$. Monoclonial antibodies against keratin filaments, specific for glandular epithelia and their tumours. Use in surgical pathology. Lab. Invest. 1983;49:353-361.

21. Schaart G. Pieper FR, Kuijpers HJH, Bloemendal H, Ramaekers FCS. Baby hamster kidney (BHK-21/C13) cells can express striated muscle type proteins. Differentiation 1991:46:105-115.

21. Verstraeten AA, Mackie EJ. Hageman PhC, Higers J, Schol DJ, De Jongh GJ. Schalkwijk J. Tenascin expression in basal cell carcinoma. Br. J. Dermatol. $1992 ; 127: 571-574$.

23. Schmitt-Gräf A, Chakroun G, Gabbiami G. Modulation of perisinusoidal coll cytoskeletal features during experimental hepatic fibrosis. Virchows Archw. A $1993: 422: 99-107$.

24. Laemmli UK. Cleavage of structural proteins during the assembly of the head of bacteriophage T4. Nature 1970;227:680-685.

25. Towbin $H$, Staehelin T, Gordon J. Electrophoretic transfer ofproteins from polacrylamide gels to nitrocellulose sheets: procedure and some applications. Proc. Natl. Acad. Sci. USA 1979:76:4350-4354.

26. Schaart G, Van der Ven PFM, Ramaekers. FCS. Characterization of cardiotin, a structural component in the myocard. Eur. J. Cell Biol. 1993;62:344-48.

27. Bochaton-Piallat ML, Gabbiani F, Ropraz P, Gabbiani G. Cultured aortic smooth muscle cells from newborn and adult rats show distinct cytoskeletal features. Differentiation 1992;49:175-185.

28. Campbell $J H$, Kocher O. Skalli O, Gabbiani G, Campbell GR. Cytodifferentiation and expression of $a$-smooth muscle actin mRNA and protein during primary culture of aortic smooth muscle cells: correllation with cell density and proliferative state. Atherosclerosis 1989;9:633-643.

29. Fager G. Hansson GK, Gown AM, Larson DM, Skalli, O. Bondjers G. Human arterial smooth muscle cells in culture: inverse relationship between proliferation and expression of contractile proteins. In vitro 1989;25:511-520.

30. Gabbiani $G$, Kocher O, Bloom SW. Vandekerckhove $₫$, Weber K. Actin expression in smooth muscle cells of rat intimal thickening, human atheromatous plaque, and cultured rat aortic media. $J$. Clin. Invest. 1984;73:148-152.

31. Clowes AW, Reidy MA, Clowes MM. Kinetics of cellular proliferation after arterial injury. I. Smooth muscle growth in the absence of endothelium. Lab. Invest. $1983 ; 49: 327-333$.

32. Yoshida $Y$, Mitsumata M, Yamane $T$, Tomikawa M. Nishida K. Morphology and increased growth rate of atherosclerotic intimal smooth muscle ceils. Arch. Pathol. Lab. Med. $1988 ; 112: 987-996$.

33. Kocher O, Gabbiani F, Gabbiani G. Reidy MA, Sami Cokay M. Pocers H. Hüttrer I. Phenotypic features of smooth muscle cells during the evolution of experimental carotid artery intimal thickenings. Biochemical and morphologic studies. $L a b$. invest. $1991: 65: 459-470$.

34. Clowes AW. Schwartz SM. Significance of quiescent smooth muscle migration in the injured rat carotid artery. Circ. Res. 1985:56:139-145.

35. Kocher $O$, Gabbiani G. Cytoskeletal features of normal and atheromatous human arterial smooth muscle cells. Hum. Pathol. 1986;17:875-880. 
36. Babaev VR, Bobryshev YV, Stenina OV. Tararak EM, Gabbiani G. Heterogeneity of smooth muscle cells in atheromatous plaque of human aorta. Am. J. Pathol. $1990 ; 136: 103 \% \div 1042$.

37. Hedin U. Holm J. Hansson GK. Induction of tenasicin in rat arterial injury. Relationship to altered smooth muscle phenotype. Am. J. Pathol 1991;139:649. 656 .

38. Hoffmann $\mathrm{S}$, Crossin $\mathrm{KL}$, Prediger EA, Cunningham BA, Edelman GM. Expression and whetion of cell-adhesion molecules during the early development of the heart. Ann. NY Acad. Sci. 1990:588:73:86.

39. Garcia-Martinez V. Sanchez-Cuintana D, Hurle JM. An immunohistochemical analysis of tenascin and type-1 collagen distribution of developing chick heart valves. Cell Tissue Res. $1990 ; 259: 299-304$.

40. Chiquet-Ehrismann $R$, Kalla P. Pearson CA. Beck K. Chïquet M. Tenascin interferes with fibronectin action. Cell 1988:53:383-390.

41. Chiquet-Ehrismann $R$. What distinguishes tenascin fron fibronectin? FASEB $J$. $1990 ; 4: 2598-2604$. 
8

\section{General summary.}

Muscle cell differentiation has been studied in skeletal, cardiac and smooth muscle cells in a broad spectrum of species and tissues, both in in vitro and in in vivo systems. The investigations described in this thesis have focussed on structural proteins that may function as markers for particular stages of differentiation. In striated muscle cells the high molecular weight protein titin is supposed to play a key role in the organization of the sarcomere. The first part of this thesis deals with the role of titin in the organization of the sarcomere (chapters 2 \& 3). Chapter 2 describes the onset of titin expression during myogenesis in mammalian cell lines of different origin. The unfolding of the titin molecule and its integration into the sarcomere during in vitro muscle cell differentiation was studied in more detail (chapter 3). Subsequently, the expression and the intracellular reorganization of this giant protein in relation to other sarcomeric constituents, intermediate filaments (IF) and desmosomal proteins was studied in rabbit embryos (chapters 4 \& 5 ). In the last two chapters (6 \& 7) the novel smooth muscle specific protein smoothelim is presented. The cytoskeletal expression of this constituent, which is exclusively expressed in fully differentiated smooth muscle cells (SMC), is studied both in normal and in pathological types of SMC.

In vitro myogenesis of skeletal muscle cells.

Myogenic cell lines have been used as models to unravel the molecular aspects of sarcomere formation in striated muscle cells. By focussing on the supramolecular structure of titin, the general mechanism that underlies the organizational changes during differentiation was studied. 
Chapter 2 describes the process of sarcomere formation in three established myogenic cell lines as monitored by the occurence and (relorganization of titin, desmin, vimentin, myosin and actin. It was demonstrated that titin is present in an early stage of differentiation and is reorganized from a punctate pattern, via stress fiber-associated aggregates, into a cross-striated pattern. In differentiating muscle cell cultures a certain delay was observed between the redistribution of titin on the one hand, and of desmin, actin and myosin on the other hand. This occurs in a typical, differentiation state dependent fashion, and suggests a leading role for titin by forming the scaffold for sarcomere formation. In addition, primary cultures of rat myocard cells were used to monitor the effect of "dedifferentiation" on the structure of sarcomeres. The sequence of events characteristic for the assembly process of cytoskeletal and sarcomeric structures observed during differentiation, was reversed during this process of dedifferentiation.

Control of differentiation of cultured human skeletal muscle cells allowed the monitoring of the dynamic process of titin assembly and its integration into the sarcomeres by antibodies to four titin epitopes. These epitopes are clearly distinguishable on the extended titin molecule as seen in maturated muscle cells. In postmitotic mononuclear myoblasts, the investigated titin epitopes were clearly separate but clustered, indicating a folded organization of the molecule. During elongation and fusion of the cells, these titin epitope signals associated with stress fiber-like structures (SFLS) and diverged, finally reaching their position at either the Z-line, the A-I junction or the A-band, as indicated by epitope-specific cross-striations. In chapter 3 we propose a model for this process, in which the large titin molecule is unfolded and guided by stress fiberlike structures. These SFLS direct the amino-terminus of the molecule towards the $Z$-line and the carboxy-terminus towards the M-line of the sarcomere. While this process of unfolding of the titin molecule progresses, other A-band or Z-line components start to migrate to their specific positions in the nascent sarcomere. The human skeletal muscle cell line appears to be a good model system to study sarcomere formation in more detail, especially since monoclonal antibodies against titin-epitopes closer to the M-line or to the Z-line are now becoming available. Also, reagents recognizing $M$-line associated proteins, like $C$-protein or H.protein, are being prepared to study their association with titin.

\section{In vivo cardiomyogenesis.}

The expression and intracellular (re)distribution of structural muscle proteins was studied during embryonic rabbit heart development. Monoclonal antibodies against titin, myosin, tropomyosin and actin, the intermediate filament proteins (VFP) desmin, keratin and vimentin, and the desmosome-associated proteins desmoplakins $1 \& 2$ were used to study sarcomere formation. Here too, titin is the first specific indicator of embryonic rabbit heart development. Upon differentiation titin reorganizes from dot-like aggregates into a cross-striated 
pattern via a transiently filamentous distribution. It has been demonstrated that the organization of tropomyosin, desmin, myosin and actin into striated patterns are preceeded by titin striation. Keratin and vimentin are initially distributed in cytoplasmic filaments, but are gradually lost during progression of cardiogenesis. Comparison of these results with studies on mouse, chick and rat revealed that the sequence of expression of muscle-specific and IFP during cardiomyogenesis is species-specific, and that expression and organization of these constituents show temporal variations for the different regions of the developing heart (chapter 4).

The role of the transient expression of certain IFP in rabbit myocard differentiation was investigated with emphasis on the interaction of keratin filaments with desmoplakin clusters. During development of the myocardium, desmoplakin clusters gradually rearrange from an apicolateral- into an intercalated disc localization in later stages. In the developing myocardium of the rabbit heart, the keratin filaments are gradually lost via dot-like aggregates which colocalize with desmoplakin-positive clusters. These observations suggest a role for keratins in the developmental rearrangement of cell-junctions. The reorganization of desmin, an intercalated disc-associated component in the adult myocard, and titin does not seem to be related to the desmosome rearrangement (chapter 5).

\section{Smooth muscle cell differentiation.}

Knowledge about differentiation processes in SMC is limited as compared to striated muscle cells. This is partly due to the lack of stage specific marker proteins. A novel cytoskeletal protein, designated "smoothelin", has been shown to be exclusively expressed in highly differentiated ("contractile") visceral and vascular smooth muscle cells. Smoothelin was not detected in myofibroblasts, myoepithelial, skeletal or cardiac muscle cells. This protein may, therefore, be helpfull in the elucidation of the final differentiation steps in SMC. Chapters $6 \&$ 7 of this thesis describe the characterization and a series of observations using this novel marker protein. A human smooth muscle cDNA library was screened with a monoclonal antibody to smoothelin, and a full size cDNA was selected. In situ hybridization with this cDNA probe demonstrated that human smoothelin is encoded by a single copy gene which is located on chromosome 22. Immunohistochemical assays, Western blotting and Northern blotting revealed that smoothelin was highly conserved throughout evolution. Cell fractionation studies of colon smooth muscle showed that the protein is retained in the cytoskeletal fraction of this tissue, while confocal scanning laser microscopy suggested that smoothelin is organized as filaments that do not colocalize with desmin, vimentin or actin filaments. Transfection studies of the human cDNA in COS7 cells produced a protein of the correct size which assembled into a filamentous network. Protein sequence analysis revealed that smoothelin does not belong to one of the classes of presently known structural proteins. 
Furthermore, smoothelin contains a domain of 56 amino acid residues showing about $40 \%$ homology with a sequence bordering the actin binding domains of dystrophin, B-spectrin and a-actinin (chapter 6). Smoothelin transcription was almost instantly halted when smooth muscle cells were removed from their natural environment, indicating that its expression is limited to highly differentiated, contractile smooth muscle cells.

The presence of smoothelin in vascular SMC was investigated in more detail. It was found that smoothelin expression was strongly related to the contractile properties of the blood vessel in which the SMC occur. Elastic arteries do, in general, contain only few smoothelin positive SMC. When muscular arteries were investigated it became obvious that the frequence of smoothelin expressing SMC increased with the contractile labour to be generated by the blood vessel wall. Smoothelin was not detected in capillaries and pericytic venules, nor in the SMC of veins. When arteriosclerotic lesions were screened for the presence of smoothelin, positive cells were detected mostly at the luminal surface of advanced lesions. This indicates that fully differentiated cells of smooth muscle origin are present in these lesions, suggesting that these plaques are not longer expanding. Thus, in addition to its value as a marker protein for the final differentiation step of "normal" SMC, smoothelin may be valuable in the diagnostic characterization of "pathological" SMC. 


\section{Samenvatting.}

Spierceldifferentiatie werd bestudeerd in skelet, hart- en gladde spiercellen, waarbij een breed spectrum aan humane- en dierlijke weefsels werd gebruikt. Studies werden zowel verricht in vitro lin gekweekte cellen) als in vivo (in levende organismen). Strukturele eiwitten dienden daarbij als "markers" , of indikators, voor bepaalde "differentiatie-" of ontwikkelingsstadia. Skelet- en hartspiercellen vormen samen de groep van "dwarsgestreepte" spieren, waarin microscopisch een groot aantal, achter en naast elkaar gerangschikte strukturen zichtbaar zijn: de sarcomeren. Deze sarcomeren vormen de contractiele eenheden binnen deze cellen. De struktuur van deze sarcomeren wordt uitgebreid besproken in hoofdstuk 1 .

Titine, een eiwit met een zeer hoog molekuulgewicht, wordt verondersteld een sleutelral te vervullen in de organisatie van de sarcomeren. De fase van aanschakeling van de titine-synthese tijdens de ontwikkeling van jonge tot volwassen spiercel, de myogenese, wordt beschreven voor een aantal cellijnen (hoofdstuk 2). Het ontvouwen van het titine-molekuul en de integratie van dit eiwit in de sarcomeer tijdens in vitro spierceldifferentiatie werd in detail bestudeerd (hoofdstuk 3). De expressie en de intracellulaire organisatie van dit eiwit in relatie met andere sarcomeercomponenten, zoals intermediaire filamenten en desmosomale eiwitten, werd bestudeerd in konijne-embryo's (hoofdstuk 4 \& 51. Tenslotte wordt smootheline, een nieuw, gladde spier specifiek eiwit, gepresenteerd. Met behulp van celbiologische- en molekulair biologische technieken werd dit eiwit, dat alleen voorkomt in volledig gedifferentieerde gladde spiercellen, gekarakteriseerd ais een onderdeel van het cytoskelet (hoofdstuk 6). Daarnaast werd de aanwezigheid van smootheline bestudeerd in de gladde spiercellen van zowel normale als aangedane bloedvaten (hoofdstuk 7). 


\section{De rol van titine tijdens de in vitro myogenese van skeletspiercellen.}

De verschillende tasen in de opbouw van sarcomeren tijdens spierceldifferentiatie werd bestudeerd aan de hand van de struktuurverandering van tithe, waarbij spiercelijnen als modelsysteem werden gebruikt. In hoofdstuk 2 wordt het proces van sarcomeervorming in drie bekende, veelvuldig gebruikte myogene cellijnen beschreven, waarbij met name de aanschakeling en de (rejorganisatie van titime, desmine, vimentine, myosine en actine werd gevolgd. Titine bleek al aanwezig in een vroeg stadium van de spierceldifferentiatie. In jonge spiercellen, de zogenaamde myoblasten, wordt titine aangetroffen in aggregaten, die onder het microscoop zichtbaar zijn als "punten". Deze aggregaten gaan stapsgewijs, via een tijdelijke associatie met stress-fibers, over in een langgerekte struktuur die na immunocytochemie resulteert in een "dwarsgestreept" patroon. Tijdens het differentiatie-proces vindt er dus een treJorganisatie van dit eiwit plaats. In gekweekte, differentiërende spiercellen blijkt het ontstaan wan een dwars-gestreept titine-patroon vooraf te gaan aan de dwarsstreping van desmine, actine en myosine. Dit vormt een sterke aanwijzing voor de leidende rol van titine tijdens de sarcomeervorming. Waarschijnlijk fungeert titime als de "kapstok" waaraan de overige sarcomeercomponenten worden opgehangen.

Opmerkelijk was dat rattehartspiercellen, die volledig gedifferentieerd zijn, een soort dedifferentiatie ondergaan nadat ze in kweek zijn gebracht. De hierboven beschreven volgorde van karakteristieke fasen tijdens de organisatie van titine blijkt in deze cellen omgekeerd te zijn. De volgorde waarin de overige cytaskeleten sarcomeer-strukturen tijdens dedifferentiatie verdwijnen blijkt ook omgekeerd te zijn aan de volgorde waarin ze tijdens de differentiatie opkomen.

De methode waarbij gekweekte humane skeletspiercellen gecontroleerd differentiëren bood de mogelijkheid om het verloop van het proces van titine-aanmaak en -integratie in de sarcomeren gedetailleerd te bestuderen. Hierbij werd gebruik gemaakt van antilichamen tegen vier titine-epitopen die duidelijk gescheiden liggen op het uitgestrekte molekuul. In. jonge spiercellen liggen deze titineepitopen duidelijk van elkaar gescheiden, maar wel in elkaars omgeving. De scherp afgebakende, puntvormige fluorescentie-signalen wijzen er op dat de titine-molekulen waarschijnlijk in bundels parallell naast elkaar liggen. De localisatie van de epitoop-specifieke signalen duidt erop dat deze bundels titine molekulen in gevouwen vorm aanwezig zijn in de cel. Tijdens elongatie en fusie van de cellen gaan deze titine-bundels een interactie aan met stress-fibers, die de titine epitopen naar hun uiteindelijke posities in de Z-lijn, de A-ll overgang, of de A-band brengen. De stress-fibers dirigeren het amino-terminale deel van het molekuul naar de Z-lijn en het carboxy-terminale deel naar de M-lijn van de sarcomeer. Een model dat de rol van stress-fibers bij de ontwouwing van het grote titine-molekuul beschrijft, wordt voorgesteld in hoofdstuk 3. Tijdens het proces van titine-ontvouwing migreren andere A-band-en Z-lijn-componenten in de richting van hun specifieke posities in de sarcomeer.

De humane skeletspiercellijn lijkt een goed modelsysteem voor gedetailleerde 
studies naar sarcomeervorming, omdat de intracellulaire processen die platsvinden gemakkelijk te bestuderen zijn en er grote overeenkomsten bestaan tussen de processen die plaatsvinden in splerweefsel en de gebeurtenissen die in deze cellijn worden waargenomen. Kombinaties van monoclonale antilichamen die specifiek $z$ ijn gericht tegen titine-epltopen dicht bil de $M$ - of de Z-lijn met antilichamen die andere $M$ - of Z -lijn geassocieerde eiwitten herkennen, bieden de mogelijkheid om de vorming van interacties tussen van titine en andere spiereiwitten in cletail te bestuderen.

\section{Strukturele eiwitten als markers voor in vivo cardiomyogenese.}

Monoclonale antilichamen gericht tegen titine, myosine, tropomyosine en actine. tegen de intermediaire filament-eiwitten desmine, keratine en vimentine en tegen de desmosoom-geassocieerde eiwitten desmoplakine 1 en 2 werden gebruikt om sarcomeervorming tijdens de embryonale hartontwikkeling (de cardiogenese) in het konijn te bestuderen. Titine blijkt ook hier weer de eerste specifieke marker voor de (hart/spierontwikkeling te zijn. Tijdens differentiatie van myoblast naar funktionele hartspiercel verandert de titine-organisatie van aggregaten, via een filamenteuze tussenfase, in bundels van parallelle, uitgestrekte titine-molekulen die een halve sarcomeer overspannen. Pas nadat deze struktuur is aangelegd nemen andere eiwitten, zoals tropomyosine, desmine, myosine en actine, hun uiteindelijke positie binnen de sarcomeer in. Dit resulteert dan na immunokleuring in het bekende dwarsgestreepte patroon voor deze eiwitten. In de jonge hartspiercellen zijn keratine en vimentine aanwezig in fillamenteuze vorm. met name in de vroege stadia. Deze filamenten verdwijnen fase-gewijs tijdens de cardiogenese. Vergelijking van deze resultaten bij het konijn met studies bij de muis, de kip en de rat toonde aan dat de volgorde van de expressie deze eiwitten tijdens de cardiogenese kleine verschillen kan vertonen. Ook bleek dat de mate van expressie en de organisatie van deze componenten op bepaalde tijdstippen tijdens de cardiogenese verschillend is voor de verschillende regio's van het hart (hoofdstuk 4).

De rol van bepaalde cytoskeletaire eiwitten die slechts gedurende een korte periode tijdens de ontwikkeling van het rryocard tot expressie komen, werd onderzocht aan de hand van de interactie van keratine-filamenten met desmoplakine $1 \& 2$. Desmaplakines maken deel uit van desmosomen, strukturen voor de communicatie tussen cellen, die zich op de verbindingsplaatsen tussen hartspiercellen, de "intercalaire schijven", bevinden. Tijdens de ontwiklkeling van het myocard verschuiven desmoplakine-clusters, die zich in everste instantie in het cytoplasma van de cel bevinden, naar de intercalaire schijven. De keratinefilamenten verdwijnen uit het zich ontwikkelende myocard via een tussenstadium van aggregatie. Zowel de keratine-filamenten (in de vroege stadia) als de keratine-aggregaten lin een later stadium) colocaliseren met de desmoplakineclusters, hetgeen suggereert dat de keratine-filamenten een rol spelen bif de positionering van desmoplakines en de vorming van cel/cel-contactplaatsen 
tijdens de ontwikkeling van het myocard. De reorganisatie van titine en desmine likkt niet direkt gerelateerd aan de herrangschikking van de desmosomen.

\section{Smootheline, een marker voor gladde spiercel differentiatie.}

De kennis over de differentiatieprocessen van gladde spiercellen is beperkt in vergelitking tot hetgeen bekend is omtrent dwarsgestreepte spiercellen. Dit wordt mede veroorzaakt door een gebrek aan stadiumafhankelijke marker-eiwitten. Van een niet eerder beschreven eiwit, door ons "smootheline" genoemd, werd aangetoond dat het alleen tot expressie komt in uitgedifferentieerde ("contractiele") viscerale en vasculaire gladde spiercellen. Smootheline werd niet gevonden in myofibroblasten, myoepitheliale cellen, skelet- of hartspiercellen. Dit eiwit zou een goede marker kunnen zijn bij onderzoek naar de laatste differen-tiatiefase in gladde spiercellen. De hoofdstukken 6 en 7 van dit proefschrift beschrijven de karakterisatie van smootheline en een serie observaties waaruit het belang van dit eiwit als marker blijkt.

Een humane cDNA bank van gladde spier werd gescreend met een monoclonaal antilichaam tegen smootheline, en het complete cDNA coderend voor dit eiwit werd geselecteerd. In situ-hybridisatie met dit cDNA toondle aan dat smootheline wordt gecodeerd door éen enkel, zogenaamd single copy, gen op chromosoom 22. Met behulp van immunohistochemische kleuringen, Western- en Northernblotting werd aangetoond dat smootheline sterk geconserveerd is tijdens de evolutie. Uit celfractionerings-studies, waarbij gebruik gemaakt werd van colon gladde spier, is gebleken dat smootheline deel uit maakt van de cytoskeletaire fractie van dit weefsel. Confocale scanning laser microscopie suggereerde dat smootheline is georganiseerd in filamenten die niet colocaliseren met desmine-, vimentine-, of actine-filamenten. Transfectie-studies, waarbij humaan smootheline cDNA in COS7 cellen tot expressie werd gebracht, gaven een filamenteus netwerk in het cytoplasma te zien, dat werd gevormd door een eiwit met het juiste molekuulgewicht. cDNA-sequentie-analyse liet zien dat smootheline niet behoort tot één van de klassen van de tot nu toe bekende strukturele eiwitten. Smootheline bevat echter wel een domein van 56 aminozuren met een homologie van ongeveer $40 \%$ met een sequentie die grenst aan de actine-bindende domeinen van dystrophine, (s-spectrine en a-actinine (hoofdstuk 6). De transcriptie van smootheline werd vrijwel onmiddelijk gestopt wanneer cellen uit hun natuurlijke omgeving werden gehaald en in kweek werden gebracht, waarschijnlijk door de verandering van de omgeving van de cel en het ontbreken van omgevingsfaktoren afkomstig van omliggend weefsel of uit het bloed. Het ontbreken van smootheline in gekweekte cellen geeft ook aan dat de expressie alleen voorkomt in gedifferentieerde, contractiele gladde spiercellen.

In een studie naar de aanwezigheid van smootheline in vasculaire gladde spiercellen bleek dat de expressie van het eiwit sterk gerelateerd was aan de mate van contractiliteit van het bloedvat-type waarin de gladde spiercellen aanwezig waren. Elastische arteriën (zoals de aorta) bevatten, in het algemeen, slechts een 
klein aantal smootheline-positieve gladde spiercellen. Bij de bestudering van musculaire arteriën bleek dat het percentage van het aantal spiercellen dat smootheline tot expressie brengt toeneemt met de contractiele arbeid die de wand van het bloedvat moet leveren. Smootheline werd niet gevonden in capillairen, pericytische venules of de gladde spiercellen van venen. Tijdens het onderzoek naar het voorkomen van smootheline in arteriosclerotische vaatwandbeschadigingen ("aderverkalkingen"') bleek dat positieve cellen meestal werden gevonden in het luminale deel van vergevorderde beschadigingen. Dit geeft aan dat volledig gedifferentieerde, van gladide spier afkomstige cellen aanwezig zijn in deze beschadigde locaties, hetgeen suggereert dat deze verkalkingen ("arteriosclerotische plaques") niet meer expanderen. Mogelijk heeft smootheline naast $z^{\prime} n$ waarde als markereiwit voor de laatste fase van differentiatie van normale gladde spiercellen dus ook waarde bij de diagnostische karakterisatie van gladde spiercellen in afwijkende, pathologische weefsels. 


\section{List of publications:}

H.L. Leenders. T.J. de Vieg. F. T.L. wan der Loop and B.G. Jenks.

Synthesis and processing of pro-opiomelanocortin in active and inthibited mice intermediate lobes.

Acta Endocrinologica (Copenh.) 1990;122:527-534.

F.J. Jongeneellen, F.E. van Leeuwen, S. Oosterink, R.B.M. Anzion, F. T.L. van der Loop, R.P. Bos and H.G. van Veen.

Ambient and biological monitoring of coke oven workers: determinations of the internal dose of polycyclic aromatic hydrocarbons.

British Journal of Industriall Medicine 1990:47:454-461.

F.T.L. van der Loop, G. Schaart, W. Langmann, F.C.S. Ramaekers, and Ch. Viebahr. Expression and organization of muscle specific proteins in the early developmental stages of the rabbit heart.

Anatomy and Embryology 1992:185:439-450.

Frank T.L. van der Loop, Gert Schaart, Helma Langmann, Frans C.S. Ramaekers and Christoph Viebahn.

Rearrangement of intercellular junctions and cytoskeletal proteins during rabbit myocard development.

European Journal of Cell Biology $1995 ; 68: 62 \% 69$.

F.T.L. van der Loop, A.A. Bosma, J.H. Vos, M.H. Mirck, G. Schaart,

T.S.G.A.M. van den Ingh and F.C.S. Ramaekers.

Cultured pig rhabdomyosarcoma cells with a deletion of the Xq24-qter chromosome region: an immunochemical and cytogenetic characterization.

American Journal of Veterinary Research 1995;56:1062-1069.

Frank T.L. van der Loop, Guillaume J.J.M. van Eys, Gert Schaart and Frans C.S. Ramaekers.

Titin expression as an early indication of heart and skeletal muscleu differentiation in vitro. Developmental re-organization in relation to cytoskeletal constituents.

Journal of Muscle Research and Cell Motility: In press.

Frank T.L. van der Loop, Peter J.J.M. Wan der Ven. Dieter O. Fürst, Mathias Gautel, Guillaume van Eys and Frans C.S. Ramaekers.

lintegration of titin into the sarcomeres of cultured differentiating human skeletal muscle cells.

European Journal of Cell Biology: In press.

Frank T.L. van der Loop, Gert Schaart, Erika D. Timmer, Fians C.S. Ramaekers and Guillaume J.J.M. van Eys.

Smoothelin, a novel cytaskeletal protein specific for smonth imuscle cells.

The Journal of Cell Biology: submitied for publication.

Frank T.L. van der Loop, Giulio Gabbiami, Frams C.S. Ramaekers and

Guillaume J.J.M. van Eys.

Smoothelin: a marker for differentiated human smooth muscile cells in normal arteries and arteriosclerotic lesions.

Arteriosclerosis. Thrombosis and Vascular Biology: submitted for publication. 


\section{Curriculum vitae.}

Frank (Franciscus Theodorus Lambertus) van der Loop werd geboren op 8 oktober 1964 te Oss. In 1983 behaalde hij thet Atheneum-B diploma aan het Titus Brandsma Lyceum te Oss. In datzelfde jaar begon hij zijn studie Biologie aan de Katholieke Universiteit Nijmegen. Het doctoraalexamen, binnen de fysiologisch/biochemische afstudeerrichting, werd in november 1988 behaald, en omvatte het hoofdvak Dierfysiologie (neuro-endocrinologie; Dr. H.L. Leenders) en de bijvakken Toxicologie (Dr. F.J. Jongeneelen) en Toegepaste Biologie (bedrijfsstage bij R.C.C. NOTOX. "s-Hertogenbosch; Dr. P.J.J.M. Weterings \& Ir. Y.H.M. van Erp). Het diplama Stralingshygiëne, deskundigheidsniveau 3, werd tijdens deze periode behaald. Na een uitstapje naar de Militair Geneeskundige Dienst, ter vervulling van de militaire dienstplicht, werd hij in 1990 aangesteld als Assistent In Opleiding bij de vakgroep Moleculaire Celbiologie \& Genetica (Prof. Dr. F.C.S. Ramaekers) van de Rijksuniversiteit Limburg te Maastricht, in het kader van het E. Dekker-programma van de Nederlandse Hartstichting. Tijdens deze aanstelling werd de opleiding tot funktionaris ex artikel 9 van de Wet op de Dierproeven gevolgd, en werden werkbezoeken gebracht aan de afdeling Anatomie (PD Dr. Ch. Viebahn) van de Rheinische Friedrich-Wilhelms Universität in Bonn (1990-1994) en de afdeling Pathologie (Prof. Dr. G. Gabbiani) van de Universiteit van Genève (augustus 1994). 


\section{Dankwoord.}

Het is iedereen wel duidelijk dat het loplbouwen van een proefschrift geen soloaangelegenheid is. Allereerst wil ik dus iedereen bedanken die mede de fundering heeft gelegd voor, danwel een steen(tje) heeft bijgedragen aan de totstandkoming van dit boekje. Hierbij wil ik het cement zeker niet vergeten. Daarom bedank ik allereerst alle medewerkers van de vakgroep Moleculaire Celbiologie \& Genetica voor de leuke tijd die ik heb gehad binnen de afdeling. Natuurlijk wil ik ook ledereen die tot mijn "Limburg"- of mijn "Brabant"-connection behoort bedanken voor de vitermate prettige tijd (en de steun).

Toch wil ik een aantal mensen met name noemen.

Mijn promotor, Frans Ramaekers, wil ik bedanken voor de omdat hij mij de gelegenheid heeft gegeven om een promotie-onderzoek te verrichten. Beste Frans, bedankt voor zowel het vertrouwen als voor de kritische noten die je plaatste bij het door mij geleverde werk en (vaak in de vorm van speurtochten) in de door mil geproduceerde manuscripten. Ik weet zeker dat ik er mijn voordeel mee heb gedaan.

Een belangrijke rol in de afgelopen periode heeft mijn "ghost" - of "shadow"promotor, Guillaume van Eys, gespeeld. Guillaume, bedankt voor de prettige samenwerking, voor de vele (al dan niet opgevolgde) suggesties en adviezen (eigenwijs zijn we toch allemaal ?!), en voor het mede-bekijken en -interpreteren van mijn bijdragen aan "de plaatjescultuur van MCB". Ook wil ik Jeanette en de kinderen bedanken voor de vele "heet"-culinaire (voetbal-)avonden. Tot slot:

Sorry dat ik jouw droom om met een jonge collega vast te komen zitten in een lift zo wreed heb verstoord; het was geen opzet.

Gert Schaart wil ik bedanken voor de hulp bij mijn eerste stappen op het gebied van de structurele eiwitten in spiercellen, en voor de prettige tijden als kamergenoot, als collega bij meerdere werkbezoeken aan Bonn, en als reis(bege-) leider/collega naar diverse (gespierde) congressen.

Mijn paranimfen, Edith Coonen en Monique Tinnemans, waren de eersten der AlO-musketiers binnen de vakgroep. Jullie hebben er voor gezorgd dat $i k$, als derde strijder binnen het genootschap, op een gemakkelijke en prettige manier kon integreren in het zuiden. "All for one, and one for all" was (en is) zeker van toepassing. De bijdragen van de overige leden van het MCB/AIO-genootschap, vooral van de musketiers vier en vijf, en van de Appie Happie-klup mogen hierbij ook niet worden onderschat.

This thesis would not have been as it is now without the contribution of Dr. Christoph Viebahn and Mrs. Helma Langmann of the University of Bonn. Dear Christoph and Helma, thank you for your collaboration, your patience, and your hospitality. Working with you was always a joy. I would like to thank Prof. Dr. 
Giulio Gabbiani for the opportunity he gave me to visit his laboratory for one month, and I would like to thank the people in his laboratory for their hospitality. Alle leden van de Hartenklup van MCB, natuurlijk inclusief de student-leden, bedankt voor de samenwerking, en "keep it pumpin', just do it".

De leden van de beoordelingscommissie will ik bedanken voor het kritisch doornemen van het manuscript.

Tot slot wil ik graag mijn ouders bedanken omdat ze mij altijd een echte, veilige "thuis"-haven bieden, ook wanneer de zee niet wlak is of wanneer ik (soms iets teveelh stoom af moet blazen. Pap en mam, bedankt. 